UNIVERSIDADE DE SÃO PAULO

INSTITUTO DE GEOCIÊNCIAS

\title{
DOLOMITIZAÇÃO E FOSFOGÊNESE NA FORMAÇÃO BOCAINA, GRUPO CORUMBÁ (EDIACARANO)
}

\author{
Gabriella Talamo Fontaneta \\ Orientador: Prof. Dr. Paulo César Boggiani \\ DISSERTAÇÃO DE MESTRADO \\ Programa de Pós-Graduação em Geoquímica e Geotectônica \\ SÃO PAULO \\ 2012 \\ VERSÃO CORRIGIDA
}



Meus queridos, que ocupam todos os pedacinhos do meu coração: minha família e meu Emiliano - esse trabalho é dedicado a vocês junto com meu amor incondicional. 



\section{AGRADECIMENTOS}

Gostaria de deixar expresso meus sinceros agradecimentos a todos aqueles que me auxiliaram a concretizar esse trabalho, e não foram poucos. Tentarei citar alguns nomes que compartilharam comigo grandes momentos nesses três anos de trabalho.

Em primeiro lugar, agradeço ao Instituto de Geociências pela oportunidade de realizar a pesquisa e aos funcionários que permitiram esta realização. Agradeço ao $\mathrm{CNPq}$ (Conselho Nacional de Pesquisa) pelo incentivo à pesquisa, sob a forma de bolsa de estudos.

Agradeço aos professores do Instituto de Geociências, em especial aos professores Setembrino Petri, Benjamin Bley de Brito Neves e Thomas Fairchild por ajudar a enriquecer meu trabalho. Aproveito para agradecer também ao professor Aroldo Misi (UFBA) pela participação no trabalho de campo.

Meus sinceros agradecimentos aos colegas da pós-graduação e graduação que estiveram presentes nas disciplinas e discussões geológicas. Um agradecimento mais do que especial a minha querida amiga Alexandra Fernandes Oliveira, não só por me auxiliar nas disciplinas, mas por todas as incontáveis risadas, pelas longas conversas e por todo o apoio incondicional. Agradeço ainda aos meus amigos, sem os quais minha vida seria muito mais difícil: Daniela Elias Bongiolo, Desirée Liechoscki de Paula Faria e Rafael Augusto Reginato. Obrigada por vocês existirem!

Agradeço ao meu orientador, Paulo César Boggiani, por todos os anos de pesquisa que aconselhou meu trabalho, incentivou minhas idéias e contribuiu para meu crescimento pessoal e profissional. Meu mais sincero: muito obrigada!

Sem esquecer, gostaria de agradecer aos meus colegas e amigos de trabalho da Petrobras especialmente aos geólogos Leonardo Tedeschi, Daniel Martins de Oliveira, que me ajudaram com as discussões e interpretações, e Oscar Strohschoen, por incentivar e permitir a finalização tranqüila da minha dissertação. Sem palavras para agradecer ao Alexandre Melo de Brito por tudo.

Por fim, agradeço à minha família. Este poderia ser o mais longo dos agradecimentos, especialmente porque é difícil resumir em poucas palavras o que cada um significa em minha vida. Aos meus pais, Antonio e Andréa, que com paciência, sempre me incentivaram a buscar meus sonhos. Aos meus avós, cada um com sua experiência de vida, me mostrararm com sabedoria o caminho das pedras. À minha irmã, Danielle, pelo seu apoio incondicional. Aos meus padrinhos, Graça e Nelson, por todos os conselhos e risadas. À minha família "de coração", Bernadete, Ariovaldo e Reny, pela presença constante. E ao meu querido, meu amor, companheiro e paixão Emiliano, meu sincero obrigada por absolutamente tudo - você sabe que sem você, eu não teria conseguido. Amo vocês. 

É necessário ter o caos aqui dentro para gerar uma estrela Friedrich Nietzsche 



\section{RESUMO}

FONTANETA, G.T. Dolomitização e Fosfogênese na Formação Bocaina, Grupo Corumbá (Ediacarano). 2012. 148 p. Dissertação (Mestrado) - Instituto de Geociências, Universidade de São Paulo, São Paulo, 2012.

Dolomitos são rochas carbonáticas abundantes no registro sedimentar Pré-Cambriano, porém raras no registro Fanerozóico e sua gênese até hoje permanece como um enigma da geologia, conhecido como o "Problema Dolomito". As rochas sedimentares fosfáticas são amplamente estudadas por fornecerem dados importantes sobre a evolução sedimentar e condições físico-químicas e biológicas da água do mar durante a sedimentação e a diagênese, além de constituírem os maiores depósitos econômicos de fósforo do mundo. Os dolomitos e fosforitos da Formação Bocaina foram estudados com base na individualização de fácies sedimentares e petrografia, complementado com investigações geoquímicas (elementar e de isótopos de $\mathrm{C}$ e $\mathrm{O}$ ), a fim de discutir os processos envolvidos na gênese destas rochas. As fácies sedimentares da Formação Bocaina, caracterizadas principalmente por grainstones oolíticos, pisolíticos, e estromatólitos, indicam ambiente de águas rasas, límpidas e agitadas, interpretado como uma laguna, propícia à proliferação microbiana, com conexão restrita ao mar aberto. Estruturas tepees e pseudomorfos de cristais de gipsita sugerem condições evaporíticas para a bacia, com eventos de exposição subaérea dos sedimentos. Os dolomitos da Formação Bocaina são interpretados como secundários, originados da substituição de sedimentos calcíticos na eodiagênese, provavelmentedevido a elevada taxa de evaporação e refluxo das águas oceânicas. Modelos organogênicos para estes dolomitos não são descartados, devido à assinatura isotópica de $\mathrm{C}$ ser ligeiramente positiva $\left(\delta^{13} \mathrm{C}_{\mathrm{VPDB}}\right.$ entre 0,95 e $3,15 \%$ ). A fosfogênese é interpretada como um processo eodiagenético, ocorrido em ambiente geoquímico anóxico, corroborado pelas anomalias positivas de Ce. O excesso de matéria orgânica permitiu a formação da apatita, provavelmente bioinduzida, durante eventos de subida do nível do mar, e desta forma, os fosforitos representam um marco estratigráfico para a bacia, como uma superfície condensada. Subseqüentemente, há rebaixamento do nível do mar, registrado nas fácies de fosfarenito e de conglomerado polimítico da base da Formação Tamengo, unidade que se justapõe à Formação Bocaina, marcando o fim do ambiente lagunar restrito e a instalação de uma plataforma francamente marinha.

Palavras-chave: dolomitização, fosfogênese, dolomitos, fosforitos, estromatólito, Formação Bocaina, Ediacarano. 


\section{ABSTRACT}

FONTANETA, G.T. Dolomitization and phosphogenesis in the Bocaina Formation, Corumbá Group (Ediacaran). 2012. 148 p. Master Thesis - Instituto de Geociências, Universidade de São Paulo, São Paulo, 2012.

Dolomites are carbonatic rocks abundant in the Precambrian but rarely found in the Phanerozoic sedimentary record. Their genesis has remained as a long-standing enigma in geology, often called the "Dolomite Problem". The phosphatic rocks, which represent the largest economic deposits of phosphorus in the world, have been studied to provide some important data about the sedimentary evolution and physical-chemical and biological condition of seawater during the sedimentation and diagenesis. The dolomites and phosphorites of the Bocaina Formation were studied based on sedimentary facies, petrography, geochemistry and carbon and oxygen isotopes investigations, to understand the process involved in the genesis of both rocks. The sedimentary facies of the Bocaina Formation are characterized by stromatolites, oolitic and pisolitic grainstones, which indicate shallow, clear and agitated water, favorable to microbial growth. The paleoenvironment was interpreted as a lagoon with restrict connection to the sea. Tepees structures and pseudomorphs of gypsum crystals suggest evaporitic condition to this basin, and also show evidences of aridity. The Bocaina Formation's dolomites have been interpreted as secondary, from replacement of limestones during eodiagenesis by reflux of oceanic waters. Organogenic models are also consideraded as a process to form these dolomites, based on the positive carbon isotope signature $\left(\delta^{13} \mathrm{C}_{\mathrm{VPDB}}\right.$ between 0.95 and $\left.3.15 \%\right)$. The phosphogenesis has been interpreted as eodiagenetic process occurred in anoxic geochemical environment, due to the excess of organic matter, mediated by microbial process. The positive $\mathrm{Ce}$ anomalies support this interpretation. This process occurs during rising of sea level and the phosphorites represent a stratigraphic mark as a condensed surface. Subsequently, it is observed a sea level lowering, recorded in phospharenite facies and in basal polymict conglomerate of Tamengo Formation, unit which overlies the Bocaina Formation. This lowering event marks the end of the restrict lagoon environment and the installation of a marine platform.

Keywords: dolomitization, phosphogenesis, dolomites, phosphorites, stromatolites, Bocaina Formation, Ediacaran. 


\section{SUMÁRIO}

1. INTRODUÇÃO

2. OBJETIVOS E JUSTIFICATIVA ………

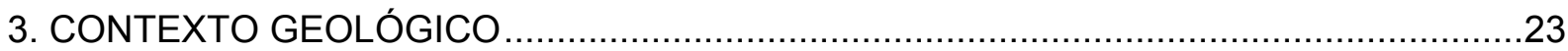

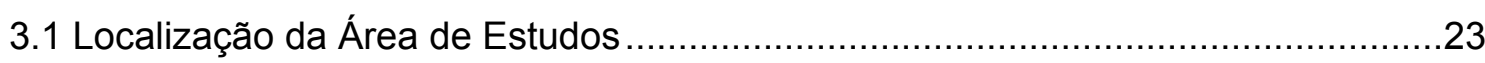

3.2 Domínio Geotectônico da Faixa Paraguai............................................................

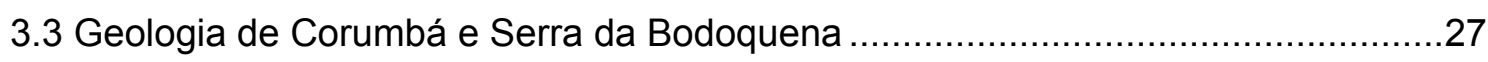

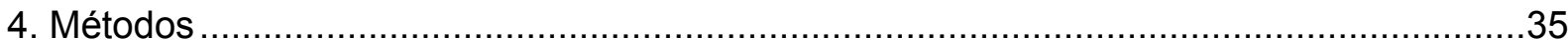

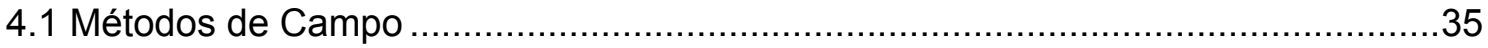

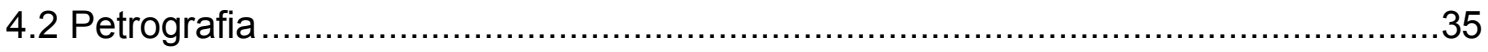

4.2.1 Classificação de Rochas Carbonáticas....................................................36

4.2.2 Classificação de Rochas Fosfáticas Sedimentares ...................................38

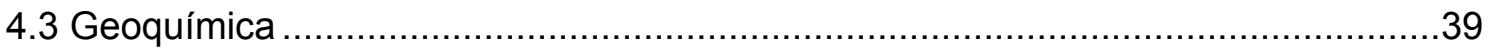

4.3.1 Elementos maiores, menores e traços para os dolomitos ...........................39

4.3.2 Elementos maiores, menores e traços em fosforitos .................................40

4.3.3 Elementos de terras raras para fosforitos ................................................40

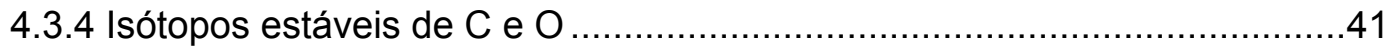

4.4 Mineralogia

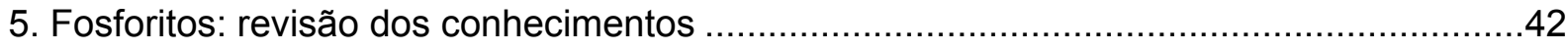

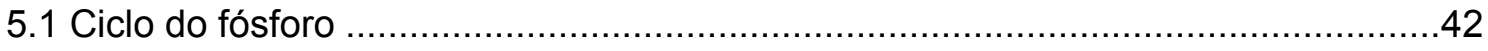

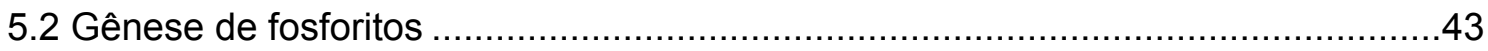

5.3 Fosforitos no tempo geológico: Neoproterozóico ................................................48

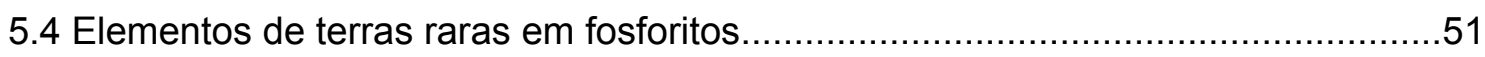

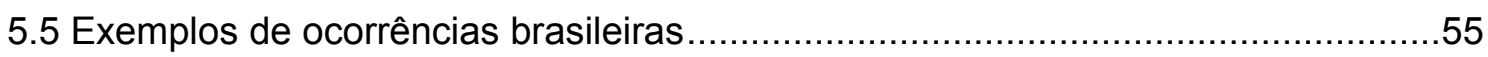

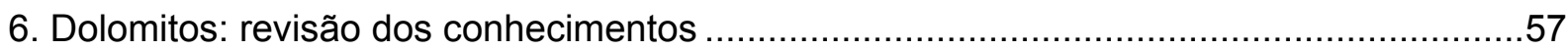

7. Petrografia das rochas da Formação Bocaina …………………………………….....64

7.1 Fácies Sedimentares da Fazenda Ressaca .....................................................64

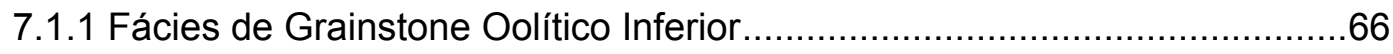

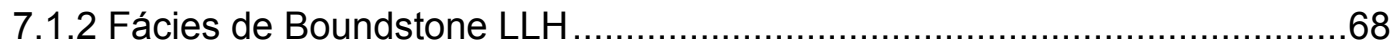

7.1.3 Fácies de Mudstone maciço ................................................................

7.1.4 Fácies de Boundstones SH...............................................................

7.1.5 Fácies de Grainstone Oolítico Superior .................................................

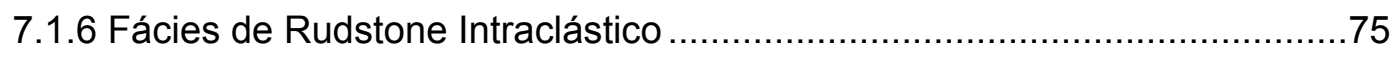

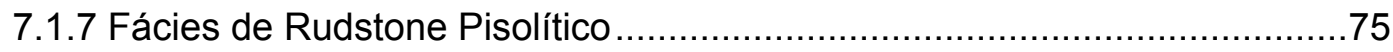

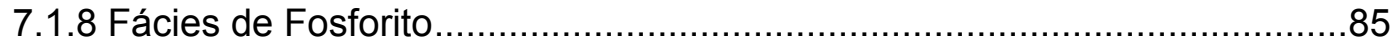

7.1.9 Fácies de Conglomerado Polimítico ………………….........................92 


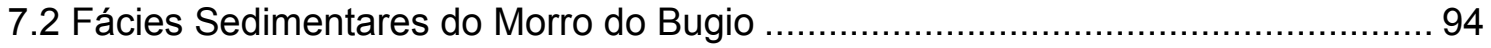

7.2.1 Fácies de Grainstone Oolítico Silicificado ............................................... 94

7.2.2 Fácies de Grainstone com oóides ...................................................... 97

7.2.3 Fácies de Rudstone Intraformacional.................................................. 98

7.3 Estromatólitos de Porto Morrinhos ................................................................... 100

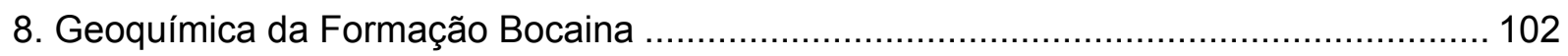

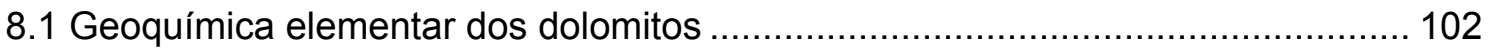

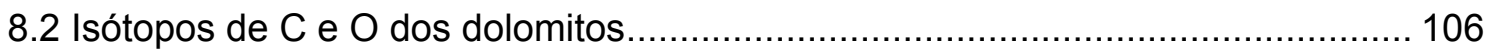

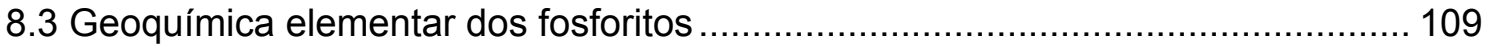

8.4 Elementos de terras raras para fosforitos.......................................................... 114

9. Gênese de dolomitos e fosforitos da Formação Bocaina ............................................. 118

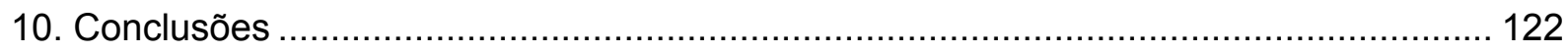

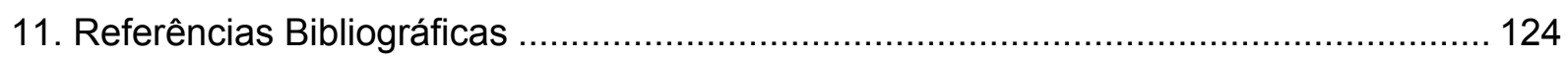

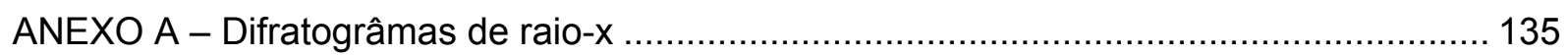

ANEXO B - Mapa de localização de afloramentos ...................................................... 141

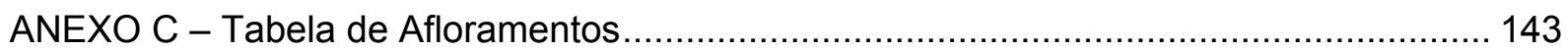




\section{LISTA DE FIGURAS}

Figura 3.1.1 - Mapa de localização da área de estudo, indicando os principais acessos a Serra da Bodoquena e Corumbá (base cartográfica: Google Maps).

Figura 3.2.1 - Perfil esquemático do modelo deposicional da Formação Puga e Grupo Cuiabá, durante a glaciação criogeniana superior (Marinoana) ( 635 Ma), ao longo da borda sudeste do Cráton Amazônico (modificado de ALVARENGA; TROMPETTE, 1992 e DANTAS et al., 2009).

Figura 3.3.1 - Mapa geológico esquemático da Serra da Bodoquena (modificado de BOGGIANI; ALVARENGA, 2004).

Figura 3.3.2 - Relações estratrigráficas entre as unidades do Grupo Corumbá (formações Cadiueus, Cerradinho, Bocaina, Tamengo e Guaicurus) e os diamictitos da Formação Puga (modificado de BOGGIANI et al., 2010).

Figura 3.3.3 - Mapa geológico esquemático da região de Corumbá, com destaque para os depósitos de ferro e manganês do Grupo Jacadigo e carbonáticos do Grupo Corumbá (modificado de TROMPETTE et al., 1998).

Figura 3.3.4 - Esquema do modelo genético proposto para a ocorrência de rocha fosfática da Formação Bocaina do Grupo Corumbá. Neste modelo, o autor interpreta uma variação lateral de fácies, nas quais a Formação Bocaina representaria as fácies de águas rasas enquanto a Formação Tamengo, as fácies de águas profundas (extraído

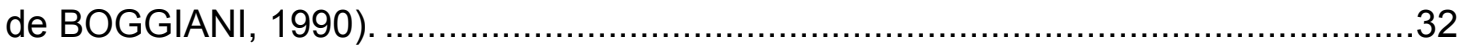

Figura 4.2.1 - Classificação e nomenclatura de calcários segundo Dunham (1962)............37

Figura 4.2.2 - Complementações de Embry e Klovan (1971) à classificação de rochas carbonáticas.

Figura 4.2.3 - Classificação de estromatólitos, baseada na morfologia externa (LOGAN et al., 1964). A nomenclatura utilizada é a abreviação dos termos em inglês: LLH laterally-linked hemispheroids (hemisferóides ligados lateralmente), $\mathrm{SH}$ - stacked hemispheroids (hemisferóides empilhados), LLH - laterally-linked/stacked hemispheroids (hemisferóides ligados lateralmente/empilhados) e SS - spheroids (esferóides) (modificado de LOGAN et al., 1964).

Figura 4.2.4 - Classificação das rochas fosfáticas, adaptada por Slansky (1986), baseada nos termos utilizados para rochas carbonáticas (FOLK, 1959).

Figura 5.2.1 - Ilustração simplificada do modelo fosfogenético de ressurgências marinhas. As acumulações de fosfato em rochas sedimentares Pré-Cambrianas são representadas, em vermelho, como: círculos (concreções e nódulos), linhas curvas (camadas finas), colunas (estromatólitos) e pequenos pontos (disseminação fina). Vários litotipos estão representados, incluindo rochas vulcânicas ("v"), granitóides 
(“+”), formações ferríferas bandadas (em preto), folhelhos (listras horizontais), calcários ("tijolinhos"), arenito (pontilhado) e conglomerado (polígonos semicirculares). Os principais processos metabólicos estão indicados em amarelo. As cores em degradê na coluna d'água representam: azul claro (zona fótica - óxica); azul escuro (zona redox transicional) e verde (zona anóxica) (modificado de PAPINEAU, 2010).

Figura 5.2.2 - Cenário proposto para a gênese da Formação Hawthorn (Flórida): A) durante a eodiagênese e B) deposição final depois do retrabalhamento sedimentar. Aumento na taxa de soterramento da matéria orgânica devido ao aumento da superfície de produtividade, resultado da intensificação das correntes de ressurgências marinhas durante períodos de nível do mar alto ou subindo. A degradação da matéria orgânica nos sedimentos leva a formação de fosforito e dolomito. Os dolomitos são formados inicialmente abaixo da zona de formação de fosforito, amplamente na zona de sulfato-redução, na forma de romboedros dispersos e cimento preenchendo os poros. A dolomitização é promovida pela dissolução de conchas aragoníticas e de calcita magnesiana, difundindo o $\mathrm{Mg}$, removendo os íons de sulfato e aumentando a alcalinidade do carbonato. $\mathrm{H}_{2} \mathrm{~S}$ produzido durante a sulfato-redução reage com os íons de Fe para formar pirita ou difunde para esteiras microbianas acima, que oxidam o $\mathrm{H}_{2} \mathrm{~S}$, transformando-o novamente em sulfato. $\mathrm{O}$ retrabalhamento dos sedimentos durante a regressão marinha concentra os grãos de fosforito e dolomito, exumando e expondo os níveis dolomíticos, removendo a matéria orgânica e pirita por oxidação (modificado de COMPTON et al., 1994).

Figura 5.3.3 - (1A) Abundância estimada de fosforito (em toneladas de $\mathrm{P}_{2} \mathrm{O}_{5}$ ) no tempo geológico, baseada nos maiores depósitos de fosforito do mundo (NOTHOLT et al., 1989) e a relação com períodos de glaciação (barras pretas horizontais no topo da figura). (1B) Número estimado de depósitos fosfáticos (avaliação baseada na reserva potencial) (NOTHOLT et al., 1989). (1C) Número estimado de depósitos fosfáticos para o Fanerozóico (após COOK; MCELHINNY, 1979); (1D) Abundância estimada de fosfato em depósitos fosfáticos (em tons de $\mathrm{P}_{2} \mathrm{O}_{5}$ ), em escala logarítimica (após COOK; MCELHINNY, 1979).

Figura 5.4.1 - Representação esquemática do modelo paleo-oceanográfico para explicação da gênese do reservatório de fósforo dissolvido em bacias oceânicas do fim do Proterozóico. (A) Oceanos não estratificados apresentam circulação vertical normal de oxigênio para partes profundas da bacia com anomalias negativas de $\mathrm{Ce}$. (B) Oceanos estratificados, com a coluna de água anóxica caracterizada por baixo Eh e $\mathrm{pH}$ devido a sulfato-redução $\left(\mathrm{H}_{2} \mathrm{~S}, \mathrm{P}\right.$ dissolvido e $\left.{ }^{12} \mathrm{C}\right)$. Condições de baixo Eh e pH 
facilitam a transformação redutora de $\mathrm{Ce}^{4+} \mathrm{em} \mathrm{Ce}^{3+}$ solúvel, permitindo desse modo o enriquecimento da coluna d'água anóxica em Ce (anomalia positiva da $\mathrm{Ce}$ ). A linha redox é a zona de separação entre as partes oxidadas e anóxicas do oceano estratificado (modificado de MAZUMDAR et al., 1999a).

Figura 5.4.2 - Distribuição dos ETR (normalizados para o folhelho PAAS) para: (a) água do Oceano Atlântico moderno (ELDERFIELD; GREAVES, 1982) e fosforitos/partículas fosfáticas mundiais - (b, c, d, g) para grãos, nódulos e calcários fosfáticos; (e) fosforitos peloidais e (f) fósseis fosfáticos (modificado de SHIELDS; STILLE, 2001).54

Figura 6.1 - Corte transversal de esteira microbiana da Lagoa Vermelha (RJ). É possível observar a alternância de lâminas com precipitação de carbonato (cores brancas) e lâminas orgânicas não-litificadas (verde). Escala, a esquerda, em centímetros (VASCONCELOS et al., 2006).

Figura 7.1.1 - Coluna estratigráfica do topo da Formação Bocaina e base da Formação Tamengo na Fazenda Ressaca, município de Bonito, MS.

Figura 7.1.2 - Romboedros de dolomita delimitando a borda dos oóides. À direita, observar que o núcleo do oóide está preenchido por quartzo. Nicóis paralelos (à esquerda) e nicóis cruzados (à direita).

Figura 7.1.3 - Núcleo de oóides preenchidos com quartzo e carbonato. Observa-se cimento dolomítico também entre os grãos oolíticos. Nicóis paralelos (à esquerda) e nicóis

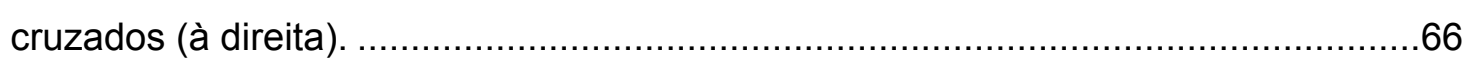

Figura 7.1 .4 - Estromatólito com laminação pseudo-colunar.............................................68

Figura 7.1.5 - Laminação estromatolítica vista ao microscópio petrográfico. Observar a alternância de lâminas de dolomita e quartzo. Nicóis paralelos, à esquerda e nicóis cruzados, à direita.

Figura 7.1.6 - Partículas arredondadas, ovais e irregulares identificadas pelo envoltório preto, constituídas possivelmente de micrita ou matéria orgânica.

Figura 7.1.7 - Estromatólitos pseudo-colunares e oncólitos.

Figura 7.1.8 - Estruturas circulares interpretadas como oóides. Nicóis paralelos (à esquerda) e nicóis cruzados (à direita). Notar a substituição de carbonato por quartzo no núcleo dos oóides.

Figura 7.1.9 - Aspecto macroscópico da fácies de grainstone oolítico superior. À esquerda, estratificações cruzadas parcialmente silicificadas e à direita, detalhe da fácies, destacando a textura oolítica.

Figura 7.1.10 - Aspecto da fácies de grainstone oolítico superior ao microscópio petrográfico, notar oóides recristalizados e presença de intraclastos micrítico, 
inclusive como núcleo dos grãos envelopados (à esquerda) e macro-oóide, ou pisóide, com dupla laminação envoltória preservada (à direita).

Figura 7.1.11 - Bloco in situ na Fazenda Ressaca, a partir do qual foram definidas as heterogeneidades da fácies de rudstone pisolítico. Os números à esquerda correspondem a: (1) mudstone maciço, (2) rudstone pisolítico com fosfato e (3) rudstone pisolítico não fosfatizado. Observar a alternância das sub-fácies em aproximadamente $50 \mathrm{~cm}$ de espessura do bloco. À direita estão especificadas as amostras coletadas. 76

Figura 7.1.12 - À esquerda, cristais prismáticos interpretados como pseudomorfos de cristais de gipso e à direita, contato irregular do mudstone maciço (porção inferior da foto, de coloração mais escura) com rudstone pisolítico com fosfato (porção superior da foto, de coloração mais clara). Nicóis paralelos. 77

Figura 7.1.13 - Detalhe do contato entre a sub-fácies de mudstone maciço (1, na base) com a sub-fácies de grainstone pisolítico com fosfato (2, topo). Observar as partículas escuras na sub-fácies 2 , que correspondem às partículas fosfáticas. 78

Figura 7.1.14 - Partículas fosfáticas presentes na sub-fácies de grainstone pisolítico com fosfato. À esquerda, possível pelóide fosfático e à direita, grão revestido fosfatizado.78

Figura 7.1.15 - Na imagem de MEV pode-se observar o pisólito parcialmente fosfatizado, cujas porções em cinza mais claro representa apatita e em cinza mais escuro, dolomita (variação composicional confirmada no EDS). Observar a irregularidade da laminação.

Figura 7.1.16 - Detalhe das lâminas dolomíticas (porção mais escura) e lâminas fosfáticas (porção mais clara). Observar que a apatita é criptocristalina, enquanto a dolomita cristais maiores (imagem de MEV). 79

Figura 7.1.17 - Detalhe da banda dolomítica (ao centro da imagem, cinza mais escura) em contato com as porções fosfatizadas (cinza mais claro) (imagem de MEV).

Figura 7.1.18 - Aspecto macroscópico da sub-fácies de rudstone pisolítico não-fosfatizado. Observar a elevada densidade de pisódes que raramente estão em contato.

Figura 7.1.19 - Pisóides visto ao microscópio petrográfico. Observar a laminação irregular, crenulada e interrompida. Notar a matriz micrítica aprisionada entre as lâminas do grão revestido.

Figura 7.1.20 - Detalhe do cimento entre os pisóides. Na imagem da direita são destacadas as três fases de cimentação dolomítica observada ao microscópio petrográfico: (A) primeira fase de cimentação em franja, $(B)$ segunda fase de cimentação também em franja (separada da primeira fase pela linha tracejada em amarelo) e (C) fase final de cimentação espática no centro do antigo poro. 
Figura 7.1.21 - À esquerda, matriz micrítica entre os "fantasmas de grãos revestidos", e à direita, observa-se níveis de mudstone dolomítico rompido e levemente dobrado com fina laminação plano-paralela

Figura 7.1.22 - Formação de grãos revestidos fosfáticos. A zona ativa de precipitação de fosfato (ZOP) ocorre nos 5-20 cm superficiais de sedimento. Em zonas de elevada produtividade, a fosfogênese é estimulada primariamente pela produção de fosfato nas águas intersticiais derivada da degradação microbiana, em zona subóxica, nos sedimentos ricos em matéria orgânica (SOM). Isso ocorre em associação com a redução de $\mathrm{NO}_{3}{ }^{-}, \mathrm{SO}_{4}{ }^{2-}$ e dos óxidos de $\mathrm{Mn}$ e $\mathrm{Fe}$, sendo limitada nos intervalos mais profundos pela falta de $\mathrm{F}^{-}$derivado da água do mar e a elevada alcalinidade decorrente da degradação acumulativa da matéria orgânica. (A) Formação de limites de discordâncias de grãos fosfáticos. Ciclos de erosão e deposição ocasionados pela migração da ZOP na coluna de sedimentos. (B) Formação de grãos agregados fosfáticos redox. O fluxo episódico de carbono orgânico para o fundo oceânico faz a interface redox deslocar-se verticalmente nos sedimentos através ZOP em resposta a mudanças na demanda biológica de oxigênio (BOD). O tipo da laminação depende da quantidade de matéria orgânica e a composição dos sedimentos. 1= interface redox $\mathrm{Fe}^{3+}-\mathrm{Fe}^{2+} ; 2=$ interface redox $\mathrm{SO}_{4}{ }^{2-}-\mathrm{H}_{2} \mathrm{~S}$. (C) Grãos híbridos formados quando ambos os processos agem juntos [modificado de Pufahl \& Grimm (2003)] . 84

Figura 7.1.23 - Aspecto do fosfautito com veios preenchidos por calcedônia (nicóis paralelos

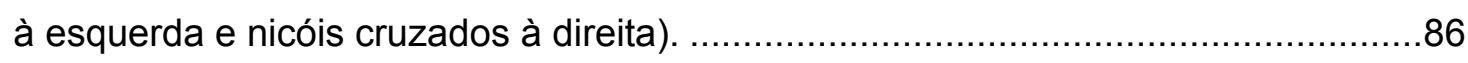

Figura 7.1.24 - Possíveis pseudomorfos de gipso disposto em matriz fosfática afanítica. Observar padrão característico da geminação do mineral: à esquerda, geminação em cotovelo e à direita, arranjo radial dos cristais.

Figura 7.1.25 - Estruturas globulares constituídas de apatita, de formas esféricas, com 40 $\mu \mathrm{m}$ de diâmetro, estruturadas por arranjo de cristais euedrais hexagonais com tamanhos por volta de $2 \mu \mathrm{m}$ (imagens obtidas por MEV, a direita detalhe da imagem da esquerda)......

Figura 7.1.26 - As imagens obtidas por MEV mostram possíveis estruturas fossilíferas encontradas no fosforito da Fazenda Ressaca.

Figura 7.1.27 - Possível estrutura fossilífera encontradas no fosforito da Fazenda Ressaca partida ao meio, destacando arranjo poligonal da parede interna (imagem obtida por MEV).

Figura 7.1.28 - Filamentos de possíveis estruturas fossilíferas. À direita, detalhe da imagem da esquerda (imagens obtidas por MEV). 
Figura 7.1.29 - Partículas fosfáticas alongadas, à esquerda, e à direita, detalhe da partícula com incipiente laminação finamente crenulada.

Figura 7.1.30 - Poro originário da dissolução do núcleo do grão, preenchido por apatita euhedrica (à esquerda) porosidade tipo fenestral preenchida por argilo-minerais (à direita)

Figura 7.1.31 - Aspecto geral do fosfarenito. Notar a heterogeneidade da granulação.

Figura 7.1.32 - Núcleo clástico dissolvido e preenchido por apatita acicular, assim como os interstícios (à esquerda, nicóis paralelos e à direita, nicóis cruzados). 90

Figura 7.1.33 - Aspecto do fosfarenito, com grãos bem arredondados de fosfato, isótropos a nicóis cruzados (à direita), com cimento de óxido de ferro.

Figura 7.1.34 - Aspecto macroscópico do conglomerado polimítico da base da Formação Tamengo (Mina Laginha, Corumbá). Notar a heterogeneidade litológica dos clastos.93

Figura 7.1.35 - Aspecto do conglomerado polimítico em seção delgada. Observar clastos de fosforito isótropos sob nicóis cruzados em matriz dolomítica recristalizada (direita). 93

Figura 7.2.1 - Oóides da fácies de grainstone oolítico silicificado. Observar a laminação concêntrica e a total silicificação. À esquerda, nicóis paralelos, e à direita, nicóis cruzados.

Figura 7.2.2 - Variedade de grãos revestidos da fácies de grainstone oolítico silicificado. Observar a laminação concêntrica porém o formato curvilíneo do grão e a total silicificação. À esquerda, nicóis paralelos, e à direita, nicóis cruzados 95

Figura 7.2.3 - Grão revestido com laminação truncada. A porção central indica que o grão estava parado durante sua formação, enquanto a porção externa, cuja laminação é contínua, demonstra que houve movimentação durante esta fase de desenvolvimento do grão revestido. À esquerda, nicóis paralelos, e à direita, nicóis cruzados.

Figura 7.2.4 - Resquício de dolomito em oóide silicificado da fácies grainstone oolítico silicificado. À esquerda, nicóis paralelos, e à direita, nicóis cruzados. 96

Figura 7.2.5 - Grãos de quartzo junto de oóides da fácies de grainstone oolítico silicificado. À esquerda, nicóis paralelos, e à direita, nicóis cruzados 96

Figura 7.2.6 - Veio de sílica cortando o oóide, indicando que corresponde a um processo posterior a formação e cimentação dos grãos revestidos. 96

Figura 7.2.7 - Nível de brecha intraformacional intercalado ao grainstone com oóides. 97

Figura 7.2.8 - Aspecto macroscópico da brecha intraformacional. Observar os clastos centimétricos a decimétricos, tabulares, angulosos, rompidos e arqueados de dolomito em matriz dolomítica. Interpreta-se que esta estrutura seja gerada por processos repetitivos de contração e expansão da superfície deposicional, durante a 
alternância de períodos de exposição subaérea e presença de água, com cristalização e dissolução de minerais carbonáticos e/ou evaporíticos (estrutura

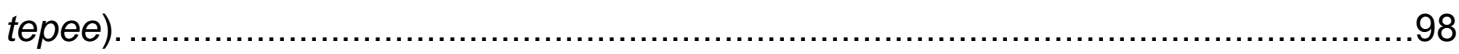

Figura 7.2.9 - Aspecto microscópico da brecha intraformacional. À esquerda, observa-se clastos de mudstone e grãos detríticos de quartzo também dispersos na matriz dolomítica (nicóis paralelos). À direita, observa-se elevada concentração de grãos de quartzo detríticos em matriz dolomítica (nicóis cruzados).

Figura 7.3.1 - Detalhe dos estromatólitos de Porto Morrinhos. À esquerda, etromatólito dômico e à direita detalhe da laminação convexa e lisa e do espaço intercolunar. .100

Figura 7.3.2 - À esquerda, brecha intraformacional e à direita, níveis centimétricos contendo partículas fosfáticas pretas sub-arredondadas. 101

Figura 7.3.3 - Desenho esquemático do afloramento de Porto Morrinhos, ilustrando os estromatólitos colunares e dômicos, bem como os níveis com clastos de fosforito e as brechas intraformacionais. No topo, o autor ilustra a camada pelítica preta, sobreposta por mudstones (FREITAS, 2010).

Figura 7.3.4 - Dolomitos de Porto Morrinhos visto ao microscópio petrográfico. À esquerda, notar a morfologia ovalada dos cristais e a presença de cimento de óxido de ferro. À direita, observar a grande quantidade de fraturas tardias preenchidas com cimento de óxido de ferro (nicóis paralelos)................................................................101

Figura 8.1.1 - Gráfico de correlação entre $\mathrm{CaO}$ e Sr para dolomitos. ...............................106

Figura 8.2.1 - Variação dos valores de $\delta^{13} \mathrm{C}$ e $\delta^{18} \mathrm{O}$ ao longo da coluna estratigráfica da Fazenda Ressaca. 108

Figura 8.2.2 - Gráfico da composição isotópica para dolomitos organogênicos. No eixo das ordenadas, os valores de $\delta^{13} \mathrm{C}$, e no eixo das abscissas, valores de $\delta^{18} \mathrm{O}$. Os valores isotópicos para a Fazenda Ressaca (pontos em vermelho) foram plotados juntos aos dados compilados de Mazzullo (2000).

Figura 8.4.1 - Curva de distribuição de ETR para fosforitos da Fazenda Ressaca, concentrações normalizadas para o folhelho PAAS.

Figura 9.1 - Bloco diagrama esquemático representando um possível modelo de distribuição das fácies sedimentares da Formação Bocaina, no ambiente lagunar com conexões restritas ao mar aberto (complexo de canais de marés). Neste esquema, também é representada a zona ativa de fosfogênese. 


\section{LISTA DE TABELAS}

Tabela 3.3.1 - Síntese das fácies sedimentares da Formação Bocaina. 31

Tabela 8.1.1 - Análise química de rocha total por FR-X para os dolomitos da Fazenda Ressaca. 103

Tabela 8.2.1 - Isótopos de C e O para dolomitos da Fazenda Ressaca. 107

Tabela 8.3.1 - Análise química de elementos maiores, menores e traços por ICP-OES para os fosforitos da Fazenda Ressaca. 111

Tabela 8.3.2 - Análise química multiespectral pelo ICP-MS da amostra FR-22 (ppm). 112

Tabela 8.3.3 - Elementos traços em fosforito analisados pelo ICP-MS (ppm) 114

Tabela 8.4.1 - Análise química de ETR para fosforito pelo ICP-MS (ppm) 115

Tabela 8.4.2 - Concentrações (ppm) de ETR normalizadas para Folhelho PAAS. 116

Tabela 8.4.3 - Anomalias de Ce, Eu e Pr e relações entre ETR. 116 


\section{INTRODUÇÃO}

O interesse no estudo de rochas fosfáticas sedimentares é secular, motivado pela sua importância econômica, já que constituem os maiores e mais importantes depósitos de fosfato do mundo, cuja aplicação principal é na indústria de fertilizantes. Além da importância econômica, os fosforitos são comumente utilizados na interpretação da evolução química e biológica dos oceanos, condições de sedimentação e diagênese, bem como em estudos mais amplos como estratigrafia de seqüências, paleogeografia e paleoambiente (SHELDON, 1981; FÖLLMI, 1996; BATURIN, 2003; KHOLODOV, 2003b).

Os dolomitos, da mesma forma, são intensamente estudados, há mais de 200 anos, do ponto de vista da petrologia sedimentar. No registro sedimentar, são abundantes no PréCambriano, mas sua ocorrência em ambientes modernos é restrita (GIVEN; WILKINSON, 1987; MCKENZIE; VASCONCELOS, 2009). Esta constatação, aliada ao fato de não ser possível sintetizar o mineral dolomita diretamente a partir da água do mar, nas condições do ambiente sedimentar, torna a gênese dos dolomitos um dos maiores enigmas da sedimentologia, conhecido como o "Problema Dolomito" (MCKENZIE, 1991).

No entanto, estudos atuais, em ambientes modernos onde se constata a precipitação da dolomita, apontam para origem primária, com participação de microorganismos (VASCONCELOS et al., 1995; VASCONCELOS; MCKENZIE, 1997; VASCONCELOS et al., 2006). Da mesma forma, as rochas fosfáticas também demonstram evidências de participação de atividade microbiana associada, direta ou indiretamente, na formação dos minerais de fosfato.

A Formação Bocaina, unidade de estudo da presente dissertação de mestrado, de idade ediacarana, aflora no sudoeste do estado do Mato Grosso do Sul, na região da Serra de Bodoquena e Corumbá. Está geotectonicamente inserida na Faixa de Dobramentos Paraguai e respectiva cobertura cratônica. Corresponde à espessa seção de dolomitos do Grupo Corumbá, com abundantes estromatólitos além de diversos tipos de grãos revestidos. As rochas fosfáticas encontram-se estratigraficamente no topo da formação, em camadas descontínuas, algumas de até $10 \mathrm{~m}$ de espessura. Este estudo baseou-se na petrografia sedimentar, com auxílio também da geoquímica elementar e isótopos estáveis de carbono e oxigênio, para o entendimento dos processos geradores destas rochas, colaborando para melhor definição do paleoambiente deposicional e diagenético da Formação Bocaina.

A comparação entre os ambientes modernos e seqüências dolomíticas neoproterozóicas pode levar à compreensão da gênese dos dolomitos ao longo da história da Terra, bem como o entendimento das formas de vida primordiais no planeta e seu papel na formação de microbialitos. 


\section{OBJETIVOS E JUSTIFICATIVA}

O presente estudo teve por objetivo estudar a Formação Bocaina no âmbito sedimentológico, enfatizando a descrição de suas fácies sedimentares para o entendimento dos processos deposicionais e diagenéticos envolvidos na dolomitização e fosfogênese, colaborando, assim, com o refinamento da interpretação paleoambiental da Formação Bocaina.

A importância científica atribuída a este estudo de mestrado está no fato de o mesmo abordar a questão controversa, relacionada à gênese de dolomitos, conhecida como o "Problema Dolomito" (capítulo 6), atualmente foco de muitos trabalhos científicos que abrangem a participação microbiana na origem destas rochas.

O estudo de fosforitos (capítulo 5), além da importância científica, por representarem marcadores estratigráficos em bacias sedimentares permitindo explicar sua evolução, possui também importância econômica, já que rochas fosfáticas sedimentares representam as maiores jazidas de fosfato do mundo, recurso mineral essencial para a agricultura.

A investigação de detalhe dos dolomitos e fosforitos da Formação Bocaina é uma contribuição, de forma geral, para o entendimento da evolução sedimentar e estratigráfica da Bacia Corumbá.

A ocorrência de fosforito da Formação Bocaina em estudo, conhecida como Fazenda Ressaca, no município de Bonito, foi alvo de trabalhos superficiais de pesquisa mineral (JUSTO, 2000) que apontaram para a potencialidade econômica da ocorrência. O Brasil não possui auto-suficiência na produção de insumos minerais para a agricultura, portanto o fosfato representa um minério estratégico, ressaltando assim a importância de estudar rochas fosfáticas.

Da mesma forma, o estudo de rochas carbonáticas em Geologia do Petróleo no Brasil esteve relativamente abandonado nos últimos anos, em função dos principais reservatórios brasileiros encontrarem-se em rochas siliciclásticas (turbiditos). Entretanto, as recentes descobertas de campos gigantes em situação geológica conhecida como "pré-sal", predominantemente em carbonatos microbiais (CARMINATTI et al., 2009), tem direcionado pesquisas sedimentológicas para essas rochas, de tal forma que a Formação Bocaina pode vir a ser um importante análogo para esses estudos. 


\section{CONTEXTO GEOLÓGICO}

\subsection{Localização da Área de Estudos}

A área de estudo do presente trabalho abrange desde a Serra da Bodoquena até as proximidades do município de Corumbá, ambos no Estado do Mato Grosso do Sul (Figura 3.1.1), onde aflora a Formação Bocaina (Figura 3.3.1).

A Serra da Bodoquena situa-se na porção sudoeste do Estado do Mato Grosso do Sul, a cerca de $320 \mathrm{~km}$ da capital Campo Grande, que por sua vez dista $1.014 \mathrm{~km}$ de São Paulo, SP. O principal acesso é pela rodovia BR-060, partindo de Campo Grande, até Guia Lopes da Laguna, seguindo para Bonito, principal cidade da região, $64 \mathrm{~km}$ através da rodovia MS-382. Corumbá dista $420 \mathrm{~km}$ da capital do estado e o acesso é feito pela BR-262 (Figura 3.3.1).

A rodovia MS-178 (Figura 3.1.1), conhecida como Bonito-Bodoquena, de direção NW-SE, acompanha a porção leste da Serra da Bodoquena e permite o acesso a grande parte dos afloramentos da Formação Bocaina (Figura 3.3.1), tanto dos dolomitos, como também permite o acesso à Fazenda Ressaca, local da principal ocorrência de fosforito.

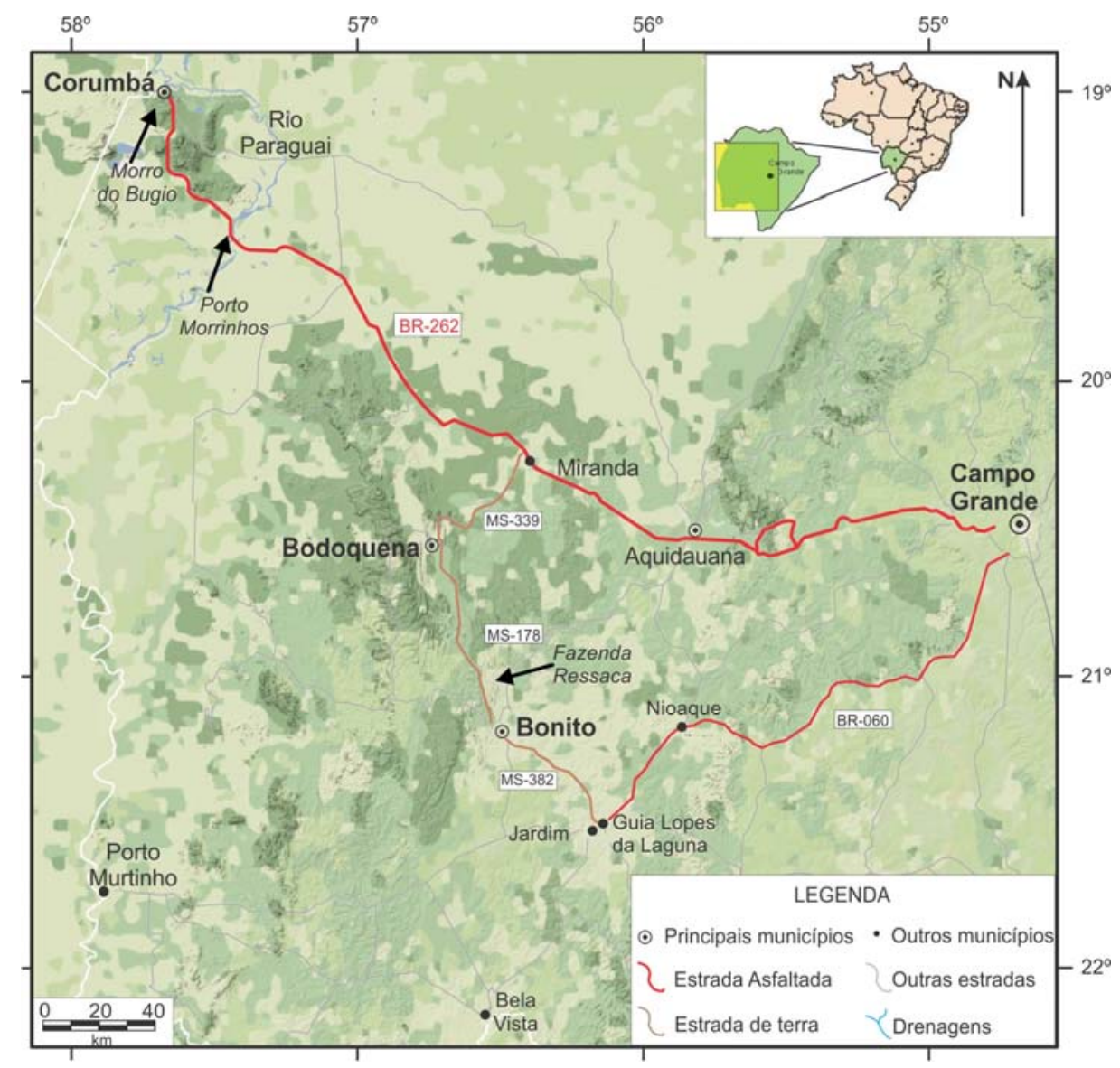

Figura 3.1.1 - Mapa de localização da área de estudo, indicando os principais acessos a Serra da Bodoquena e Corumbá (base cartográfica: Google Maps). 


\subsection{Domínio Geotectônico da Faixa Paraguai}

A Faixa Paraguai constitui uma faixa de dobramentos de idade brasiliana localizada na região Centro-Oeste brasileira, a Sudeste do Cráton Amazônico e a leste do Bloco do Rio Apa. Sua extensão é de aproximadamente $1.200 \mathrm{~km}$ de comprimento, desde a região do Rio das Mortes em Mato Grosso, passando pelas adjacências de Cuiabá, onde inflete para a direção norte-sul e se prolonga até Corumbá e Serra da Bodoquena, no Estado de Mato Grosso do Sul (BOGGIANI; ALVARENGA, 2004). É caracterizada por metassedimentos terrígenos, em fácies xisto verde, e carbonáticos, com baixo grau metamórfico, além de intensa deformação linear polifásica, longos falhamentos inversos e/ou empurrão, ausência de rochas vulcânicas aflorantes e ocorrência de granitogênese pós-tectônica nas porções mais internas da faixa (ALMEIDA, 1984).

Devido às diferenças nas composições faciológicas e paleontológicas, a Faixa Paraguai é subdividida em Meridional e Setentrional, tendo ao Norte as exposições do Grupo Araras e ao Sul as do Grupo Corumbá (BOGGIANI; ALVARENGA, 2004).

O Grupo Corumbá (ALMEIDA, 1965; BOGGIANI, 1990; BOGGIANI, 1998; GAUCHER et al., 2003), como será discutido no item 3.2, é representado por rochas silicicásticas na base (conglomerados, arenitos e pelitos das formações Cadiueus e Cerradinho), recobertas por uma sucessão carbonática de água rasa (Formação Bocaina), na qual se encontram os depósitos fosfáticos, sobrepostos por calcários e folhelhos carbonosos depositados em evento transgressivo (Formação Tamengo) com registro fóssil de Cloudina e Corumbella. Sobre estes calcários encontram-se os folhelhos da Formação Guaicurus. O Grupo Corumbá apresenta registro completo de evolução de uma bacia do tipo rifte para margem passiva (BOGGIANI, 1998).

Ainda na região de Corumbá, ocorrem formações ferríferas bandadas, com camadas de manganês na base, localizadas no Maciço do Urucum, pertencentes ao Grupo Jacadigo, posicionado estratigraficamente abaixo do Grupo Corumbá.

Para a Faixa Paraguai Setentrional, Alvarenga e Trompette (1992) individualizaram a unidade inferior, formada por sedimentos glácio-marinhos da Formação Puga e por turbiditos distais do Grupo Cuiabá (Figura 3.2.1). Esta unidade inferior é recoberta por rochas carbonáticas do Grupo Araras e uma unidade superior, siliciclástica, correspondente ao Grupo Alto Paraguai. Os metassedimentos dobrados e metamorfizados passam progressivamente, em direção ao Cráton Amazônico, a coberturas sedimentares, em parte contemporâneas, ligeiramente dobradas e falhadas, porém não metamorfizadas (ALVARENGA; TROMPETTE, 1993). 
O estudo sedimentar do Grupo Cuiabá e de seus equivalentes cratônicos mostra uma evolução lateral de sedimentação que pode ser interpretado tanto como característica de uma margem passiva, desenvolvido na borda oeste de um oceano brasiliano, como de acumulação em borda de aulacógeno ou de um rifte intracontinental (ALVARENGA; TROMPETTE, 1992).

A porção basal, tanto na Faixa Paraguai Meridional como Setentrional é representada por diamictitos da Formação Puga (MACIEL, 1959; ALVARENGA; TROMPETTE, 1992; BOGGIANI, 1998). Os depósitos glaciogênicos são interpretados como relacionados ao evento glacial Marinoano (ALVARENGA; TROMPETTE, 1992; ALVARENGA et al., 2004), ocorrido há 635 Ma (Criogeniano Superior) (ALVARENGA et al., 2004; DANTAS et al., 2009). Porém, até o presente momento, não há datação radiométrica que possibilite comprovar esta correlação, sendo estabelecida de forma indireta devido à sobreposição por calcários da Formação Tamengo, cuja idade é bem definida a partir dos fósseis metazoários Cloudina e Corumbella (ZAINE; FAIRCHILD, 1987), de idade ediacarana, além de intercalações de tufos vulcânicos, com idade por volta de $545 \pm 6 \mathrm{Ma}$ obtida pela datação U/Pb de zircões (BOGGIANI et al., 2005; BABINSKI et al., 2006).

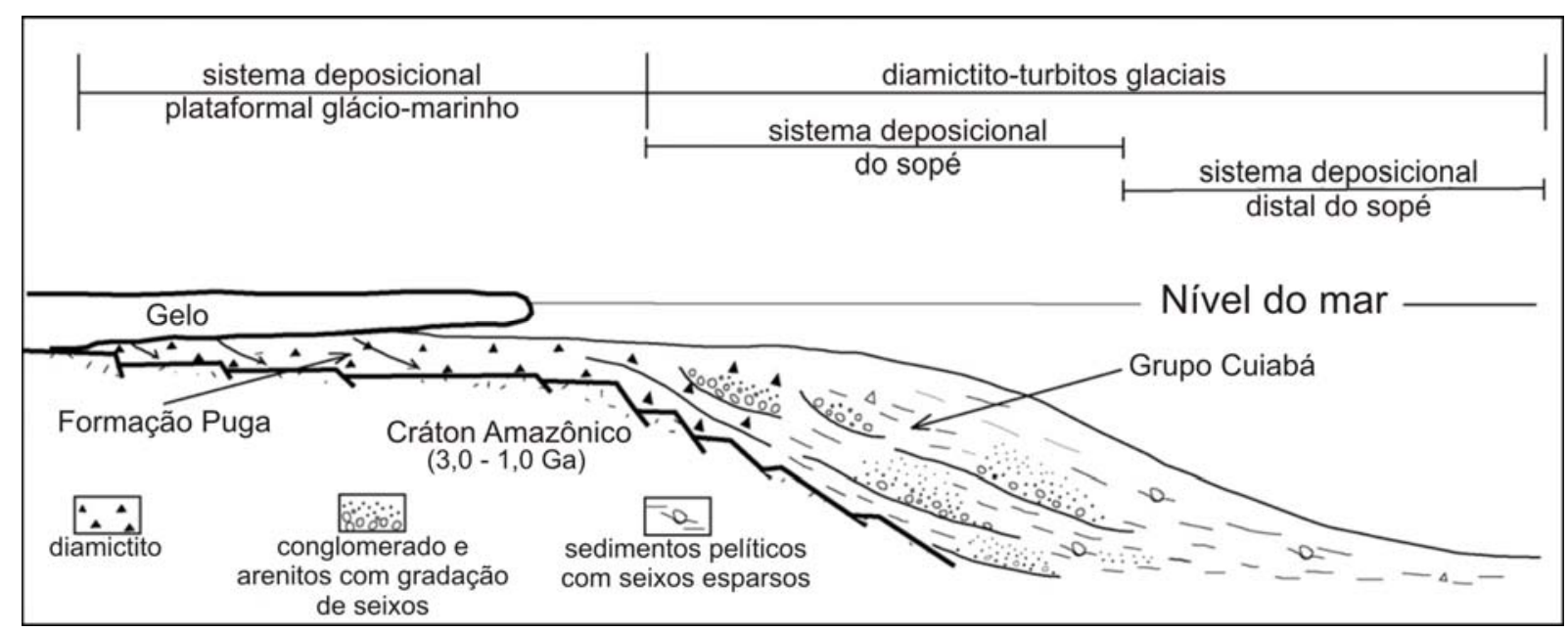

Figura 3.2.1 - Perfil esquemático do modelo deposicional da Formação Puga e Grupo Cuiabá, durante a glaciação criogeniana superior (Marinoana) ( 635 Ma), ao longo da borda sudeste do Cráton Amazônico (modificado de ALVARENGA; TROMPETTE, 1992 e DANTAS et al., 2009).

Almeida (1984) estabeleceu zoneamento tectônico para a Faixa Paraguai, considerando o grau de deformação das rochas. Nesse sentido, foram estabelecidos dois domínios chamados de Brasilides Metamórfica e Brasilides não-metamórfica, posteriormente renomeados como Zona Interna e Zona Externa, respectivamente, por Alvarenga \& Trompette (1993), além do domínio cratônico correspondendo a terceira zona estrutural. 
A porção oriental $(E)$ da faixa de dobramentos refere-se à Brasilides Metamórfica ou Zona Interna e apresenta tectonismo intenso, marcado por falhas inversas e dobras isoclinais, e metamorfismo em fácies xisto verde. Já a porção ocidental (W), que corresponde à Brasilides não-metamórfica ou Zona Externa, é representada por rochas sedimentares praticamente não metamorfizadas, pouco tectonizadas, apresentando apenas dobras abertas e suaves, cujas camadas mergulham com baixo ângulo para leste

A evolução estrutural da Faixa Paraguai foi dividida em três estágios por Almeida (1984), separados por discordâncias e mudanças contrastantes de litologia, associados a uma zonalidade tectônica e dispostos em longas e estreitas faixas paralelas à borda do cráton. O estágio supostamente mais antigo (Grupo Cuiabá) é formado por rochas intensamente dobradas, pelíticas de fácies xisto verde, intercaladas a camadas de quartzitos e calcários subordinados, metamorfizadas durante a Orogenia Brasiliana/Pan-Africana no final do Neoproterozóico e início do Cambriano (DANTAS et al., 2009). O estágio médio é definido pelos diamictitos da Formação Puga (Criogeniano, DANTAS et al., 2009), recobertos pelas sucessões carbonáticas do Grupo Corumbá e Araras, ambos contendo capas carbonáticas (capas de Mirassol d'Oeste e Morro do Puga). O estágio superior é representado pelo Grupo Alto Paraguai, predominantemente siliciclástico, discordante ao Grupo Araras, e aflorante na porção norte da Faixa Paraguai.

O último estágio é seguido de magmatismo granítico sub-alcalino pós-orogênico,

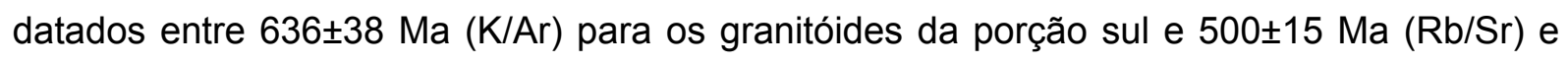
$504 \mathrm{Ma}$ (U/Pb) para a porção norte (ALMEIDA; MANTOVANI, 1975; MANZANO et al., 2010).

Dados paleomagnéticos, corroboram com a idade de 520 Ma para a colisão dos blocos Amazônico - West Africa com os blocos menores mais a oeste como o Rio Apa e Pampia (TOHVER et al., 2006).

Dantas et al. (2009), por meio de estudos de isótopos de $\mathrm{Nd}$, identificaram fontes continentais, provenientes do Cráton Amazônico, para os sedimentos basais da Faixa Paraguai, bem como idades $\mathrm{T}_{\mathrm{DM}}$ compatíveis ao Paleo e Mesoproterozóico. Já para as formações superiores, formações Raizama e Diamantino - Grupo Alto Paraguai, as composições isotópicas revelam fontes mais jovens (Neoproterozóico), interpretadas como referentes ao arco magmático de Goiás e a Faixa Brasília.

Anomalias gravimétricas para a Bacia do Pantanal foram associadas a arcos magmáticos e/ou crosta inferior alçada ao longo da zona de colisão (sutura) entre dois blocos crustais com parâmetros petrofisicamente distintos. No quadro da geologia regional, estes blocos crustais a Oeste e Leste são atribuídos respectivamente ao Bloco Rio Apa e Paraná. As assinaturas geofísicas profundas desta zona de colisão reforçam a hipótese de 
uma possível continuação para norte da Faixa Pampeana, como Faixa orogênica Paraguai, sob as coberturas sedimentares do Pantanal (FISSEHA, 2004).

A deformação dessas rochas pode ser interpretada como resultado de uma orogênese de colisão com o desenvolvimento completo do ciclo de Wilson ou como o fechamento deste aulacógeno ou rifte intracontinental, possivelmente com reduzida formação de crosta oceânica. De acordo com a primeira hipótese, o Grupo Cuiabá representaria um paleo-prisma sedimentar numa antiga margem passiva ou, de acordo com a segunda hipótese na borda oeste do aulacógeno. Nenhum vestígio de crosta oceânica ou de arcos magmáticos que poderiam estar relacionados à subducção de litosfera oceânica foi identificado na região de Cuiabá. O final do processo resultante do fechamento do Oceano do Brasiliano foi acompanhado de intrusões graníticas pós tectônicas com idades em torno de 500 Ma (ALVARENGA; TROMPETTE, 1992; ALMEIDA; MANTOVANI, 1975; MANZANO et al., 2010; CAMPANHA et al., 2011).

\subsection{Geologia de Corumbá e Serra da Bodoquena}

Na região de Corumbá ocorrem os grupos Corumbá (ALMEIDA, 1945; BOGGIANI, 1998), predominantemente carbonático, e o Jacadigo (ALMEIDA, 1945; DORR II, 1945), com os extensos depósitos de ferro e manganês. De idade estimada pleistocênica, também compõem a geologia da região depósitos de calcretes com específicos significados paleoclimáticos e paleogeográficos, bem como as tufas holocênicas da Serra da Bodoquena (ALMEIDA, 1945; BOGGIANI; COIMBRA, 1995; OLIVEIRA, 2009). Recobrindo os depósitos mais antigos, desenvolve-se, atualmente, a extensa planície do Pantanal, com sedimentos predominantemente siliciclásticos. Neste trabalho, o destaque é para o Grupo Corumbá, no qual se encontra a Formação Bocaina, alvo do estudo (Figura 3.3.1).

O Grupo Corumbá representa um conjunto de unidades sedimentares e metassedimentares siliciclásticas e carbonáticas de idade ediacarana (Figura 3.3.2), aflorantes na porção oeste do Estado do Mato Grosso do Sul, particularmente na porção leste da Serra da Bodoquena e nas adjacências do município de Corumbá (Figura 3.3.1). 


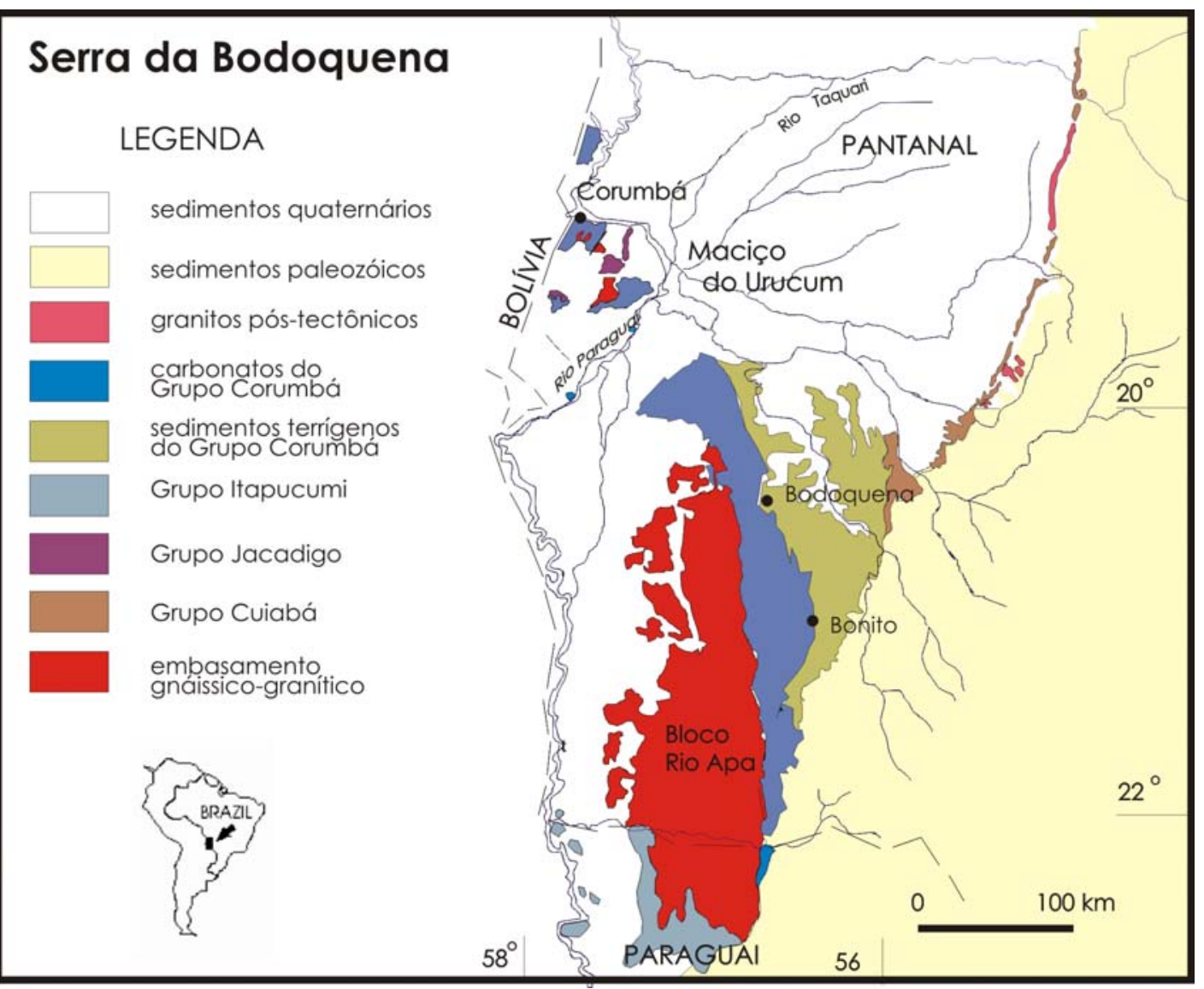

Figura 3.3.1 - Mapa geológico esquemático da Serra da Bodoquena (modificado de BOGGIANI; ALVARENGA, 2004).

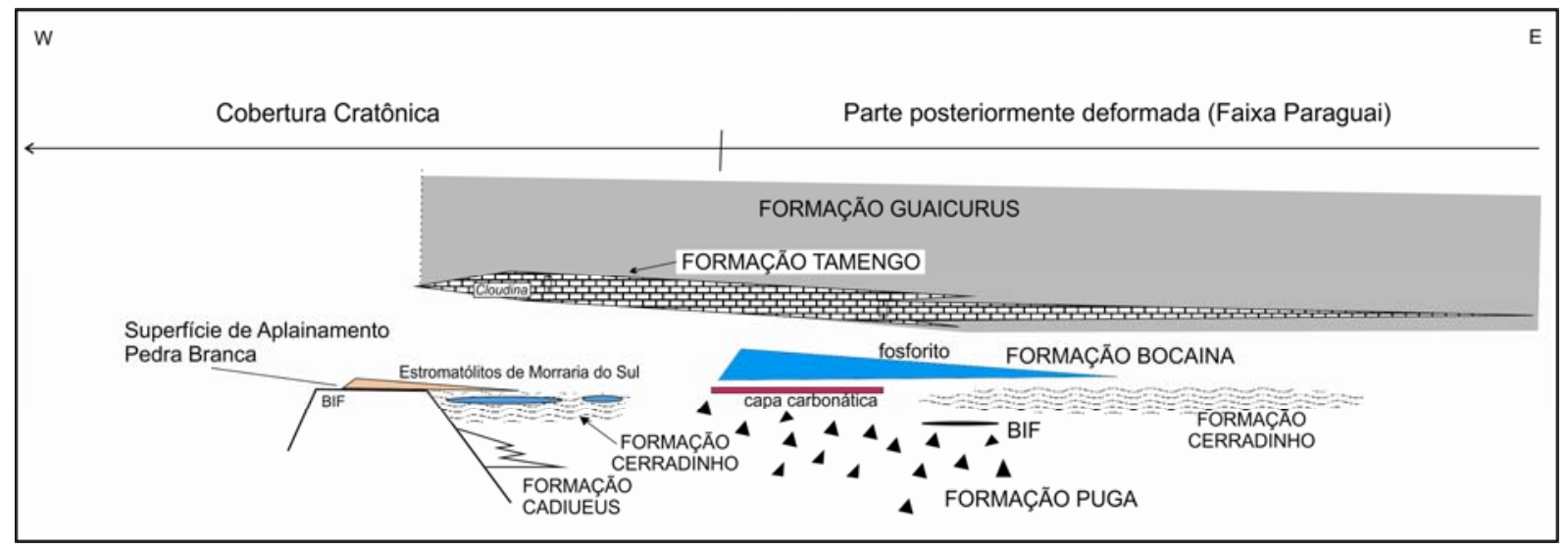

Figura 3.3.2 - Relações estratrigráficas entre as unidades do Grupo Corumbá (formações Cadiueus, Cerradinho, Bocaina, Tamengo e Guaicurus) e os diamictitos da Formação Puga (modificado de BOGGIANI et al., 2010).

Os primeiros registros das rochas do Grupo Corumbá devem-se ao estudo de rochas carbonáticas por Castelnau (1857) entre os anos de 1843 e 1847 (CASTELNAU, 1857). Posteriormente, Evans (1984) nomeou os calcários da Província Serrana, ao norte, como Araras Limestones e, ao sul, como Corumbá Limestones (EVANS, 1894). 
A geologia da região de Corumbá também teve destaque na década de 40 devido ao interesse econômico nos depósitos de ferro e manganês do Maciço do Urucum, já conhecidos desde o início do século XX. Em 1945, Almeida definiu a estratigrafia da "Série" Jacadigo como Grupo Urucum, basal, constituído por conglomerados e arcóseos e Grupo Santa Cruz, superior, representado por depósitos de ferro e manganês. No mesmo ano, Dorr II propôs outra denominação para as mesmas rochas, sendo os depósitos terrígenos basais denominados de Formação Urucum, uma unidade intermediária composta de conglomerados e arenitos com hematita chamada de Córrego das Pedras, e os depósitos de sedimentos químicos superiores de Formação Banda Alta. O contato dos grupos Jacadigo e Corumbá ainda é controverso. Trompette et al. (1998) sugerem que o contato ocorra por meio de falhas (Figura 3.3.3) enquanto trabalhos recentes apontam para a passagem gradual do Grupo Jacadigo para o Corumbá, na fase pós-rifte da bacia (FREITAS, 2010).

Almeida, em 1945, definiu também a "Série" Bodoquena, subdividindo-a nos grupos Bocaina, basal, composto por dolomitos, e Tamengo, superior, caracterizado por calcários escuros, folhelhos, siltitos e arenitos. Em 1965, Almeida reuniu as exposições carbonáticas da Serra da Bodoquena com as encontradas em Corumbá, em um único Grupo, mantendo a denominação original de Grupo Corumbá. Neste trabalho, o autor propõe a subdivisão do grupo em quatro formações, da base para o topo: Cerradinho, Bocaina, Tamengo e Guaicurus.

Posteriormente, diversas propostas estratigráficas foram definidas para o Grupo Corumbá, porém com os trabalhos específicos de Boggiani $(1990,1998)$ na região, atualmente adota-se a coluna estratigráfica original de Almeida (1965) com a inserção da Formação Cadiueus na base do grupo (BOGGIANI, 1998) (Figura 3.3.2).

A Formação Cadiueus é representada por conglomerados e arcóseos interpretados como produtos de leques aluviais e folhelhos roxos de ambiente lacustre depositados em uma bacia do tipo rifte (BOGGIANI, 1998). Esses sedimentos estão dispostos sobre o embasamento granítico-gnáissico, com exposições restritas à porção oeste da Serra da Bodoquena.

A Formação Cerradinho, aflorante também na borda oeste da referida serra é representada por arenitos, siltitos, argilitos, calcários e dolomitos, interpretados como continuidade lateral aos leques aluviais que depositaram a Formação Cadiueus, representando fácies distais de planície de maré. Sobre o embasamento, há uma superfície de aplainamento pré-cambriana sobre a qual, com elevação do nível eustático, permitiu o ingresso de águas oceânicas de forma ampla sobre o bloco cratônico. Desta forma, propiciou-se ampla sedimentação carbonática, sob condições de águas rasas e quentes, 
propícias a intensa proliferação microbiana, na forma de estromatólitos, e origem de extensos e espessos depósitos de dolomitos da Formação Bocaina (BOGGIANI, 1998).

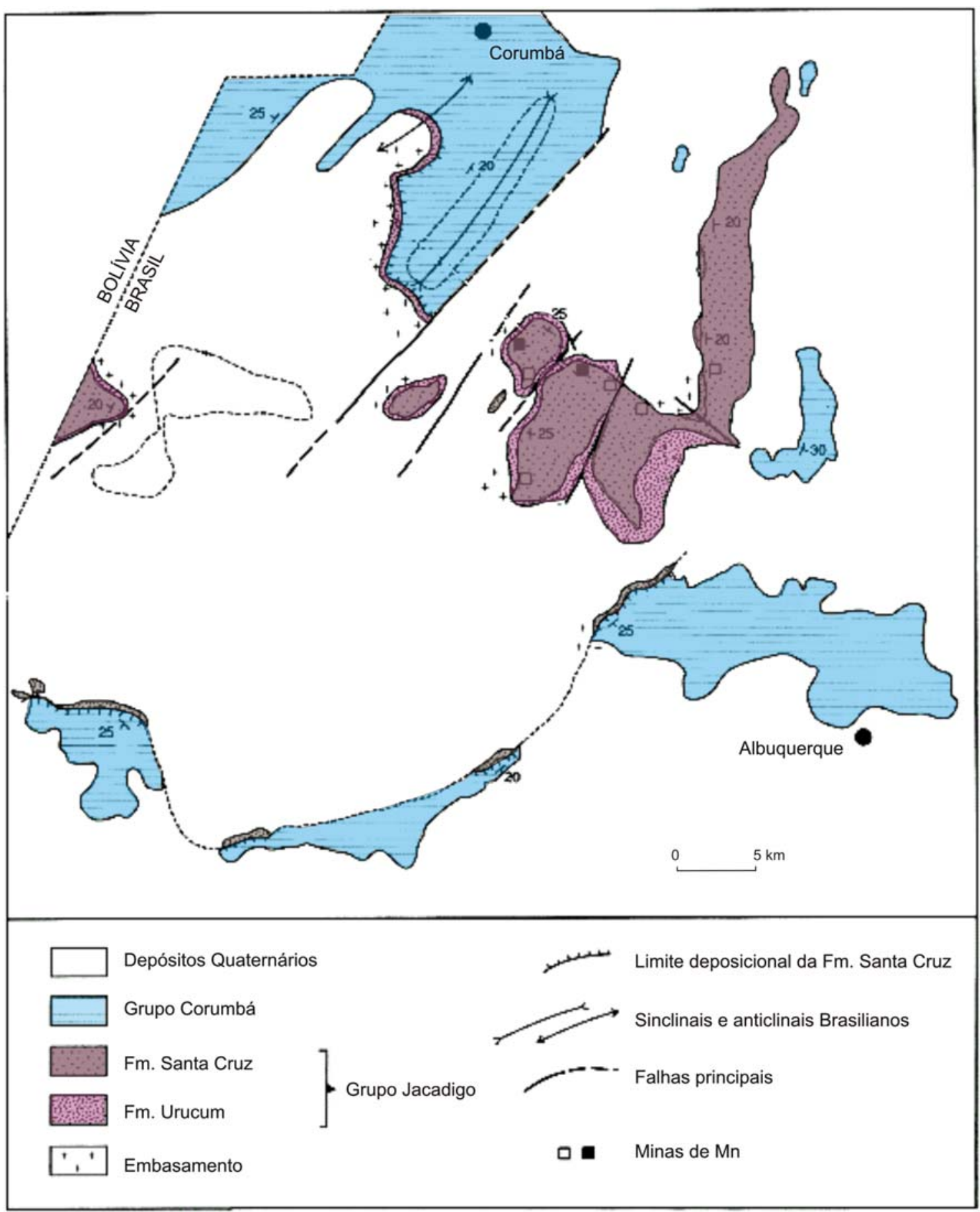

Figura 3.3.3 - Mapa geológico esquemático da região de Corumbá, com destaque para os depósitos de ferro e manganês do Grupo Jacadigo e carbonáticos do Grupo Corumbá (modificado de TROMPETTE et al., 1998). 
A Formação Bocaina, unidade de estudo deste trabalho, caracteriza-se por dolomitos com estromatólitos, oncólitos, oóides, estratificações cruzadas, brechas intraformacionais, estruturas tepees, além de rochas fosfáticas no topo da sucessão. As melhores exposições encontram-se na região de Corumbá e adjacências, onde foi definida originalmente na Garganta Bocaina (ALMEIDA, 1945), trecho da morraria dolomítica que circunda o sul da cidade de Corumbá, cortada pela ferrovia e estrada de acesso à cidade. No Planalto da Bodoquena, os dolomitos apresentam-se dobrados, intensamente marmorizados e parcialmente silicificados nas exposições da Faixa Paraguai e horizontalizados a oeste, na cobertura cratônica (BOGGIANI, 1998).

A expressão geomorfológica da Formação Bocaina são morros baixos, isolados e abaulados ou tendendo a formas cônicas. Estratigraficamente, dispõe-se sobre o embasamento aplainado e também sobre os diamictitos da Formação Puga. O contato com a Formação Cerradinho não é observado

As fácies sedimentares da Formação Bocaina foram definidas por Boggiani (1998), apesar da dificuldade de correlacioná-las devido às grandes variações laterais de fácies, distribuídas por extensão de centenas de quilômetros. A síntese das fácies é apresentada na tabela 3.3.1.

Tabela 3.3.1 - Síntese das fácies sedimentares da Formação Bocaina.

\begin{tabular}{|c|c|c|c|}
\hline Fácies & Descrição & $\begin{array}{l}\text { Estruturas } \\
\text { Sedimentares }\end{array}$ & $\begin{array}{l}\text { Ambiente de } \\
\text { Deposição }\end{array}$ \\
\hline Pisóide rudstone & Oóides $>2 \mathrm{~mm}$, córtex concêntrico & & $\begin{array}{c}\text { Costeiro } \\
\text { (baixios oolíticos) }\end{array}$ \\
\hline Rochas fosfáticas & $\begin{array}{l}\text { Microfosforito maciço, estromatólitos } \\
\text { e laminações algáceas fosfatizadas }\end{array}$ & $\begin{array}{c}\text { Maciça a } \\
\text { estromatolítica }\end{array}$ & $\begin{array}{l}\text { Costeiro sujeito } \\
\text { a upwellings }\end{array}$ \\
\hline $\begin{array}{l}\text { Dolomitos } \\
\text { estromatolíticos }\end{array}$ & $\begin{array}{l}\text { Laminações algáceas, estromatólitos } \\
\text { bulbosos e colunares }\end{array}$ & $\begin{array}{c}\text { Maciça, } \\
\text { laminada } \\
\text { e estromatolítica }\end{array}$ & Inframaré \\
\hline $\begin{array}{c}\text { Mudstones } \\
\text { alternados com } \\
\text { silexitos }\end{array}$ & $\begin{array}{l}\text { Camadas centimétricas de } \\
\text { mudstones dolomítcos alternadas } \\
\text { com camadas de silexito incolor }\end{array}$ & $\begin{array}{l}\text { Estratificação } \\
\text { plano-paralela }\end{array}$ & Inframaré \\
\hline Flakestones & $\begin{array}{l}\text { Brecha carbonática com clastos na } \\
\text { forma de placas }\end{array}$ & $\begin{array}{c}\text { Placas } \\
\text { imbricadas } \\
\text { tepees } \\
\end{array}$ & $\begin{array}{l}\text { Inter e } \\
\text { supramaré }\end{array}$ \\
\hline $\begin{array}{c}\text { Mudstones } \\
\text { dolomíticos } \\
\text { estratificados }\end{array}$ & $\begin{array}{l}\text { Estratificação plano-paralela } \\
\quad(1-2 \mathrm{~cm} \text { de espessura) }\end{array}$ & $\begin{array}{l}\text { Estratificação } \\
\text { plano-paralela }\end{array}$ & Inframaré \\
\hline Estromatólitos LLH & $\begin{array}{c}\text { Espesso pacote basal de } \\
\text { estromatólitos com laminações } \\
\text { ligadas lateralmente (LLH) formando } \\
\text { pseudo-colunas }\end{array}$ & estromatolítica & Inframaré \\
\hline
\end{tabular}

Extraído de Boggiani (1998). 
No topo da Formação Bocaina, encontram-se rochas fosfáticas sedimentares, dispostas em camada descontínua de aproximadamente $10 \mathrm{~m}$ de espessura, que aflora nas proximidades do município de Bonito.

As primeiras ocorrências do fosfato no Grupo Corumbá foram identificadas em 1976 pela Rio Doce Geologia e Mineração S/A - DOCEGEO, através de levantamento geoquímico na Serra da Bodoquena. A partir dessas informações, a CPRM (Companhia de Pesquisas de Recursos Minerais) realizou trabalho de prospecção de fosfato com o nome de "Projeto Fosfato de Bonito" (LUZ et al., 1980).

Nos trabalhos do referido projeto, foram localizados corpos fosfáticos intercalados em pelitos e metapelitos, mas com posição estratigráfica incerta, na Formação Bocaina ou na Formação Tamengo. O ambiente de deposição foi interpretado como costeiro, alternando períodos de instabilidade ou correntes marinhas marcados pela sedimentação terrígena, na qual se encontrariam os depósitos fosfáticos e períodos de calmaria, nos quais teriam se depositado os carbonatos. Desta maneira, o fosfato encontrado intercalado aos pelitos seria alóctone, produto de retrabalhamento. Nesse estudo, foi dimensionada uma reserva total inferida de aproximadamente 4 milhões de toneladas, com teor médio de 5,95\% de $\mathrm{P}_{2} \mathrm{O}_{5}$, o que levou a conclusão, naquela época, de que esses depósitos não seriam econômicos (LUZ et al., 1980).

Outras ocorrências de rocha fosfática sedimentar foram encontradas e estudadas por Boggiani (1990), com destaque para a ocorrência da Fazenda Ressaca, no município de Bonito.

O ambiente de deposição foi interpretado como costeiro de talude, sujeito a correntes de ressurgências marinhas (upwellings) (Figura 3.3.4) e a relativa ausência de terrígenos sugere calmaria tectônica durante a deposição, constituindo um ambiente propício para a origem de sedimentos fosfáticos (BOGGIANI, 1990; BOGGIANI et al., 1993).

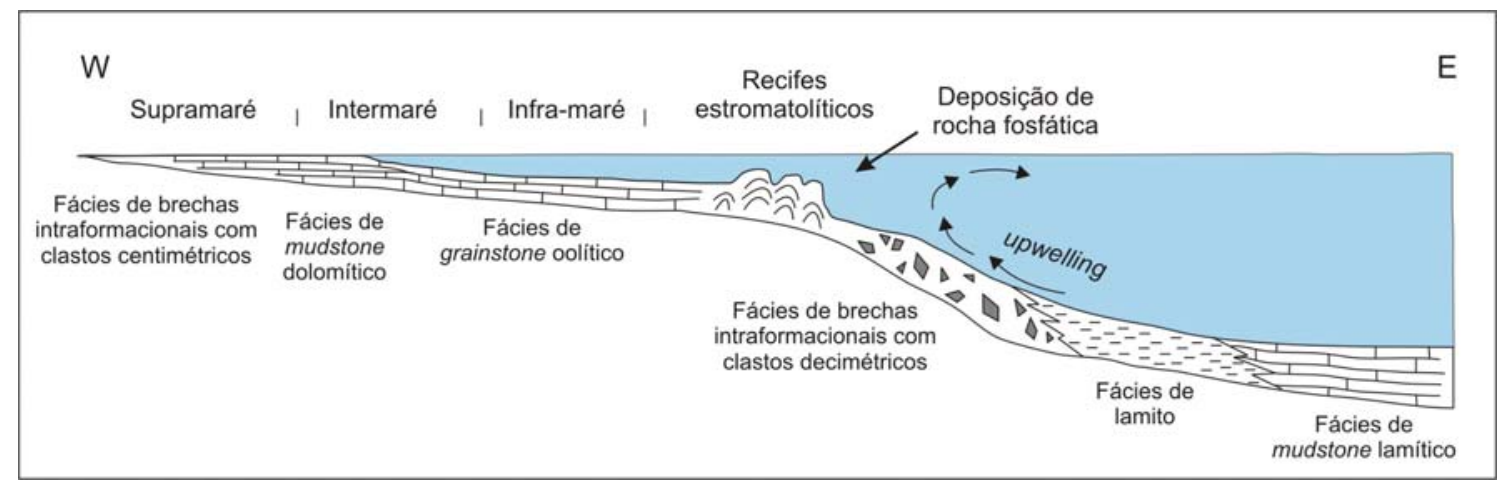

Figura 3.3.4 - Esquema do modelo genético proposto para a ocorrência de rocha fosfática da Formação Bocaina do Grupo Corumbá. Neste modelo, o autor interpreta uma variação lateral de fácies, nas quais a Formação Bocaina representaria as fácies de águas rasas enquanto a Formação Tamengo, as fácies de águas profundas (extraído de BOGGIANI, 1990). 
Posteriormente, a CPRM retomou os trabalhos de prospecção no Estado do Mato Grosso do Sul, na região da Serra da Bodoquena, com estudo mais detalhado da ocorrência da Fazenda Ressaca no projeto intitulado "Fosfato da Serra da Bodoquena, Mato Grosso do Sul" por Justo (2000). Neste trabalho, foram identificados dois tipos principais de fosforito: (i) o tipo Chert preto, com textura amigdaloidal, maciço, fratura conchoidal, muito duro, asssociado aos dolomitos do topo da Formação Bocaina; e (ii) o tipo Microbrecha, que apresenta cor cinza escura, estratificado, estruturas estromatolíticas e amigdaloidal, também associado com dolomitos estromatolíticos da Formação Bocaina. O termo "chert" foi empregado devido ao aspecto superficial do fosforito, semelhante a sílex preto e não devido à composição silicosa.

As rochas fosfáticas do Grupo Corumbá ocorrem no topo da Formação Bocaina, em camadas centimétricas de microfosforito maciço. Foram identificados também intercalações centimétricas de fosforitos maciços (microfosforitos) em folhelhos e ritmitos (folhelhos grafitosos/ mudstones pretos) da Formação Tamengo.

$\mathrm{Na}$ ocorrência da Fazenda Ressaca, foram observados também fosforitos associados com estromatólitos colunares e laminados, com teores de até $35 \%$ de $\mathrm{P}_{2} \mathrm{O}_{5}$, cujo principal mineral é a fluorapatita (BOGGIANI et al., 1993). Nesses estromatólitos foram identificadas estruturas microscópicas globulares, interpretadas como microfósseis (SALLUN FILHO et al., 1994) e fósseis esqueletais de Titanotheca coimbrae (GAUCHER et al., 2003).

A Formação Bocaina é interpretada como depositada em extensa planície de maré com transição a leste para plataforma marinha, na qual teriam se originado as rochas fosfáticas associadas a eventos de correntes marinhas de ressurgência. O ambiente de águas rasas e bem iluminado permitiu a proliferação microbiana, destacada pela presença de estromatólitos (BOGGIANI, 1998). Em âmbito de bacia, interpreta-se que a Formação Bocaina represente a transição de uma bacia restrita do tipo rifte pra uma bacia francamente marinha, durante fase de abertura oceânica (BOGGIANI, 1998).

A Formação Tamengo compreende calcários carbonosos, tipicamente de cor preta, com freqüentes intercalações de folhelhos carbonosos. Na base da formação encontram-se brechas intraformacionais, com clastos de litologias da Formação Bocaina e também do embasamento. São encontradas exposições tanto na Serra da Bodoquena, geomorfologicamente expressas como morros alongados com altitude superior aos morros relativos à Formação Bocaina, como também na região de Corumbá, onde foram encontrados fósseis de metazoários Cloudina e Corumbella, relacionados ao período Ediacarano. 
Boggiani (1998) interpretou que a brecha polimítica basal da Formação Tamengo representaria um acentuado rebaixamento do nível do mar, estabelecendo assim uma plataforma marinha com quebra de talude, na qual teria se depositado a brecha. Com a subseqüente elevação do nível do mar, depositaram-se os calcários e ritmitos em evento transgressivo. Desta forma, a Formação Tamengo representa a passagem de ambiente de águas rasas, eventualmente sujeito a exposições subaéreas, registrado na Formação Bocaina, para um ambiente francamente marinho, no qual foi possível a deposição de sedimentos pelágicos.

Mais recentemente, uma interpretação alternativa vem sendo colocada para a relação estratigráfica entre a Formação Bocaina e Formação Tamengo, com a possibilidade de não haver correlação lateral entre as duas. Desta forma, a brecha polimítica basal da Formação Tamengo representaria o siginificativo rebaixamento eustático, com exposição da Formação Bocaina e seu retrabalhamento, após o qual, com a subida do nível do mar, teria se dado a deposição das porções médias e superiores da Formação Tamengo (BOGGIANI et al., 2010).

O subseqüente afogamento da plataforma carbonática, em continuidade do evento transgressivo, já registrado na deposição da Formação Tamengo, deu origem aos espessos pacotes de folhelhos da Formação Guaicurus, encontrados desde a Serra da Bodoquena até Corumbá. O aumento do nível d'água e maior quantidade de sedimentos siliciclásticos inviabilizaram a sedimentação carbonática, permitindo a instalação de uma plataforma terrígena durante o final da sedimentação do Grupo Corumbá. 


\section{MÉTODOS}

\subsection{Métodos de Campo}

As atividades de campo abrangeram as áreas de afloramento da Formação Bocaina, desde a região da Serra da Bodoquena até Corumbá, na porção sudoeste do Estado do Mato Grosso do Sul.

Estas atividades foram divididas em três etapas, sendo que a primeira ocorreu no ano de 2008, com duração de uma semana. A segunda etapa, com duração também de uma semana também, ocorreu em março de 2009 e a terceira, com duração de 15 dias, em julho de 2009. Também foi utilizado o material coletado no ano de 2006, como parte da iniciação científica da autora, relacionada ao mesmo tema do mestrado. No total, foram coletadas cerca de 80 amostras.

De maneira geral, a Formação Bocaina aflora de forma precária, apenas como exposições isoladas, o que dificulta o levantamento de seções estratigráficas. As melhores exposições encontram-se muito a totalmente silicificadas, ou fortemente metamorfizadas.

$\mathrm{Na}$ Fazenda Ressaca, local da principal ocorrência de rochas fosfáticas, foi possível levantar uma seção estratigráfica no topo da Formação Bocaina, que compreende cerca de $200 \mathrm{~m}$ de espessura de dolomitos estromatolíticos e oolíticos sobrepostos por uma camada de rocha fosfática, descontínua, de aproximadamente $10 \mathrm{~m}$ de espessura.

No Morro do Bugio, no município de Ladário, próximo a Corumbá, também foi levantada uma seção por tratar-se de uma mina de calcário abandonada, oferecendo excelentes amostras do topo da Formação Bocaina, com as estruturas sedimentares primárias bem preservadas devido à silicificação.

Nas demais localidades foram coletadas amostras pontuais em afloramentos preferencialmente pouco deformados ou metamorfizados.

\subsection{Petrografia}

Das amostras coletadas em campo, foram confeccionadas 90 seções delgadas para observação ao microscópio óptico de luz transmitida. As observações foram realizadas no Microscópio Petrográfico Zeiss AXIOPLAN 2, no Laboratório de Petrografia Sedimentar do Instituto de Geociências da Universidade de São Paulo (IGc-USP).

Algumas amostras foram também observadas ao Microscópio Eletrônico de Varredura LEO 440I, no Laboratório de Microscopia Eletrônica de Varredura (MEV) do IGcUSP. 
A classificação dos tipos petrográficos utilizada neste trabalho esta detalhada nos seguintes subitens:

\subsubsection{Classificação de Rochas Carbonáticas}

As rochas carbonáticas possuem tanto partículas transportadas fisicamente, como por exemplo, oóides, bioclastos, pellets entre outros, e também minerais precipitados nos sítios deposicionais e diagenéticos, como cimento ou substituindo o material pré-existente.

As principais classificações para as rochas carbonáticas são de Folk (1959) e de Dunham (1962). No presente trabalho foi adotada a classificação de Dunham (1962).

Esta classificação (Figura 4.2.1) tende a ser mais simplista que a de Folk (1959), considerando basicamente a textura deposicional da rocha.

O primeiro critério da classificação é se a rocha é sustentada pela matriz (lama carbonática) ou pelo arcabouço (grãos carbonáticos). Caso a rocha seja sustentada pela lama carbonática, possuindo menos de $10 \%$ de grãos transportados, a rocha é denominada mudstone, e caso possua mais de $10 \%$ de grãos, é denominada wackestone. No entanto, se a rocha é sustentada pelo arcabouço recebe o nome de packstone quando ainda há presença de lama carbonática nos interstícios (matriz) ou grainstone quando não há lama, apenas cimento (DUNHAM, 1962).

As rochas bioconstruídas ou bioinduzidas, cujos componentes carbonáticos foram originados conjuntamente, recebem o nome genérico de boundstone (DUNHAM, 1962).

Embry \& Klovan (1971) complementaram a divisão original de Dunham, detalhando o termo boundstone, acrescendo os termos bafflestone, bindstone e framestone (Figura 4.2.2) (EMBRY; KLOVAN, 1971), que no entanto são de difícil aplicabilidade em calcários antigos. Os autores contribuíram também com os termos floatstone e rudstone, que são os equivalentes de wackstone e packstone/grainstone, porém os grãos possuem mais de $2 \mathrm{~mm}$ de diâmetro.

Para as rochas bionduzidas da Formação Bocaina, foi utilizada a classificação de Logan et al. (1964) já que esta classificação possui ênfase para a morfologia de estromatólitos (Figura 4.2.3). 


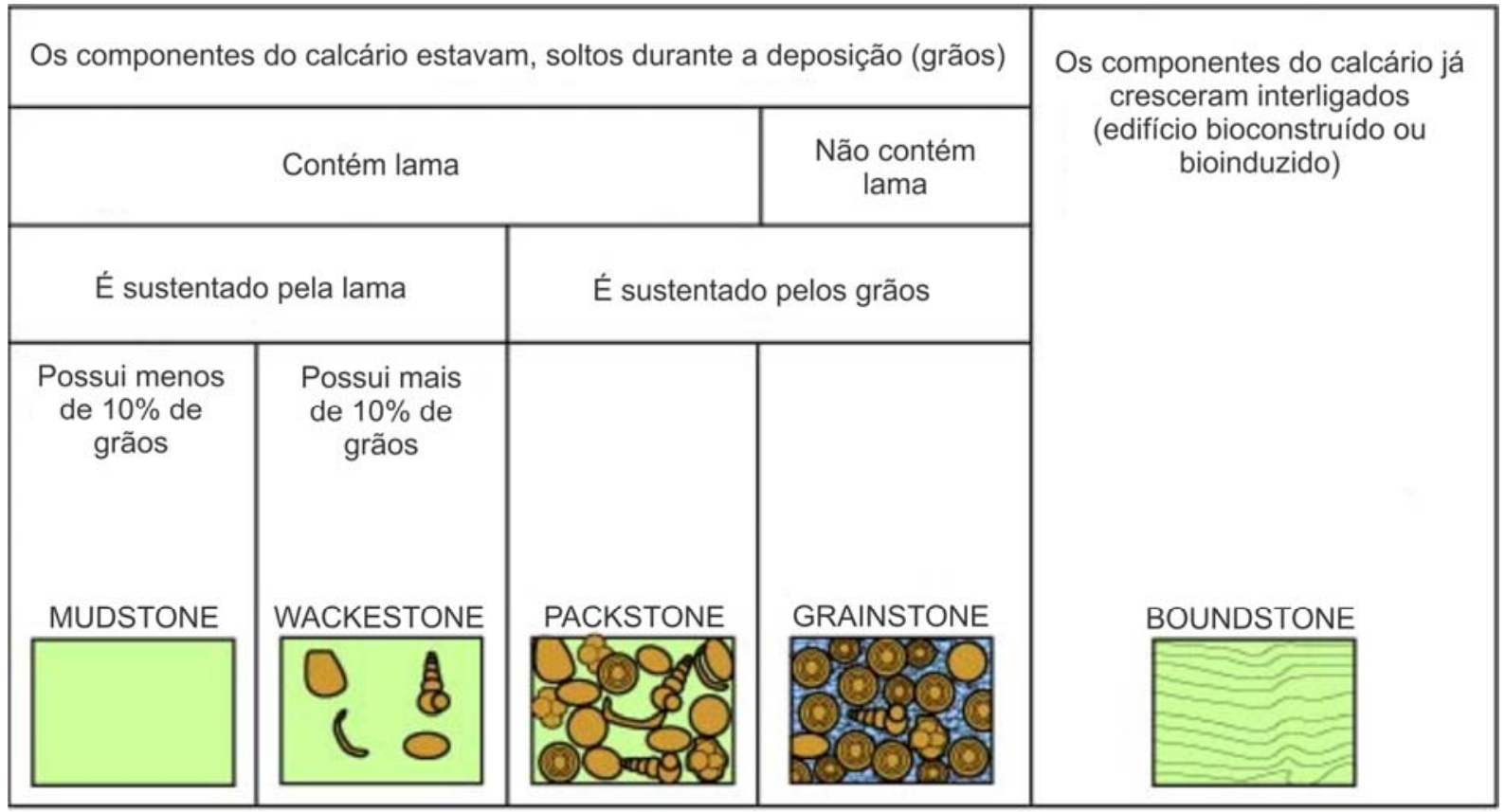

Figura 4.2.1 - Classificação e nomenclatura de calcários segundo Dunham (1962).

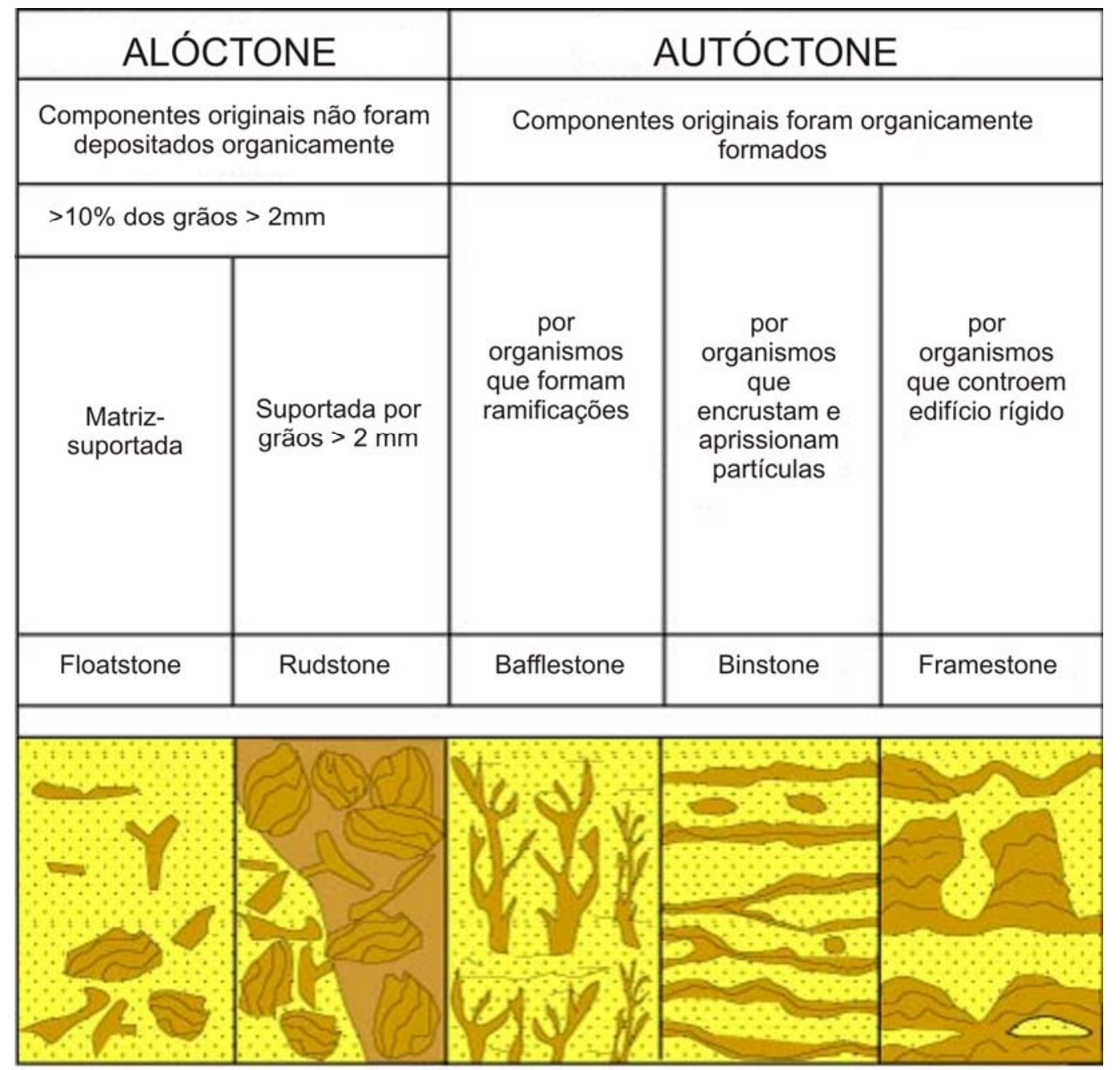

Figura 4.2.2 - Complementações de Embry e Klovan (1971) à classificação de rochas carbonáticas. 


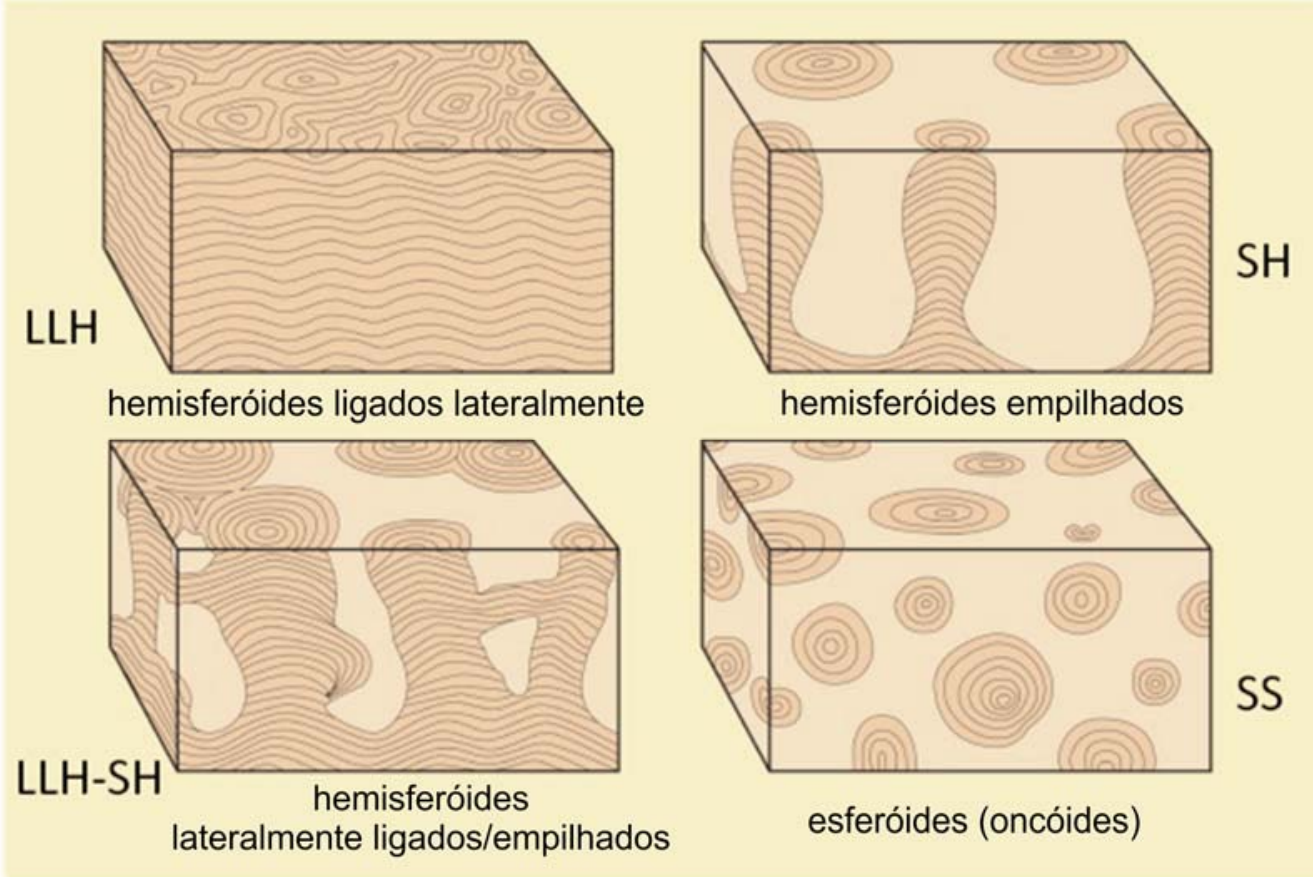

Figura 4.2.3 - Classificação de estromatólitos, baseada na morfologia externa (LOGAN et al., 1964). A nomenclatura utilizada é a abreviação dos termos em inglês: LLH - laterally-linked hemispheroids (hemisferóides ligados lateralmente), SH - stacked hemispheroids (hemisferóides empilhados), LLH - laterally-linked/stacked hemispheroids (hemisferóides ligados lateralmente/empilhados) e SS spheroids (esferóides) (modificado de LOGAN et al., 1964)

\subsubsection{Classificação de Rochas Fosfáticas Sedimentares}

Para a classificação de rochas fosfáticas, foi empregada a classificação de Slansky (1986) que compreende uma adaptação dos termos empregados por Folk (1959) para as rochas carbonáticas.

Para tal, utilizam-se os termos fosfalutito quando a granulação é inferior à 0,062 mm, fosfarenito quando a granulação compreende entre 0,062 - $2 \mathrm{~mm}$ e fosfarrudito quando a granulação for superior a $2 \mathrm{~mm}$ (Figura 4.2.4). Essa nomenclatura ainda pode ser acrescida dos prefixos oo, pel, bio e intra quando a predominância dos grãos fosfáticos for representada por oóides, pellets, fósseis ou intraclastos respectivamente (Figura 4.2.4). Assim, por exemplo, uma rocha fosfática formada essencialmente por oóides na granulação areia, pode ser denominada oofosfarenito. Já um fosforito composto por fósseis de tamanho superior a $2 \mathrm{~mm}$, pode ser classificado como biofosfarrudito. 


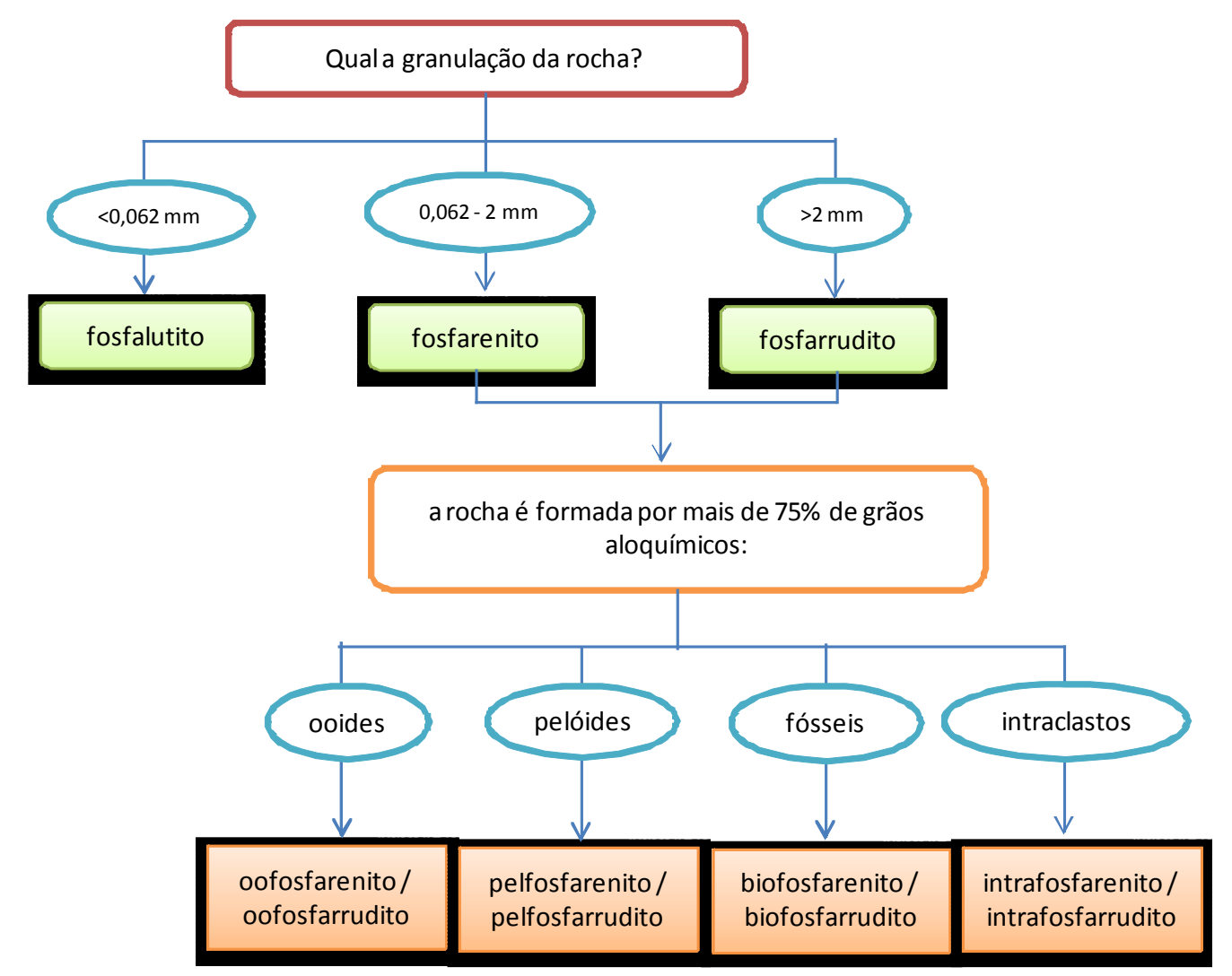

Figura 4.2.4 - Classificação das rochas fosfáticas, adaptada por Slansky (1986), baseada nos termos utilizados para rochas carbonáticas (FOLK, 1959).

\subsection{Geoquímica}

A caracterização geoquímica foi realizada por meio de análises de rocha total, para elementos maiores, menores e traços de toda a sucessão carbonática da Fazenda Ressaca, através do método de Fluorescência de raio-X (FR-X) e do depósito fosfático por ICP-OES (espectrometria por emissão ótica com plasma indutivamente acoplado). Para análise de elementos de terras raras foi empregado o método do ICP-MS (espectrometria de massa com plasma indutivamente acoplado).

\subsubsection{Elementos maiores, menores e traços para os dolomitos}

Foram analisadas 14 amostras de dolomitos da Fazenda Ressaca, mais duas duplicatas, pelo método de FR-X no Laboratório de Fluorescência de raios-x do IGc-USP.

Para elementos maiores e menores foi utilizada a pastilha fundida confeccionada no Laboratório de Química do IGc-USP, e para elementos traços foi utilizada a pastilha 
prensada, confeccionada no Laboratório de Preparação de Amostras do IGc-USP. O laboratório dispõe do equipamento automático Philips modelo PW2400.

O padrão IPT-48 foi analisado juntamente com as amostras a fim de comparar os valores obtidos com os valores recomendados.

\subsubsection{Elementos maiores, menores e traços em fosforitos}

As análises de elementos maiores, menores e traços para 4 amostras de fosforitos mais 1 duplicata foram realizadas no Laboratório de Química do IGc-USP, pelo ICP-OES, modelo 3410 da ARL.

Para a análise por ICP-OES, as amostras foram inicialmente britadas, cominuídas em prensa hidráulica e por fim, moídas em moedor de bolas de ágata. Em uma alíquota de $0,25 \mathrm{~g}$ do pó seco das amostras foi adicionado $0,75 \mathrm{~g}$ da mistura dos sais tetraborato de lítio e metaborato de lítio seco (1:4), e introduzido em mufla elétrica a $1000{ }^{\circ} \mathrm{C}$ por 20 minutos, em cadinho de grafite. $O$ material fundido foi avolumado com $150 \mathrm{~mL}$ de água e $25 \mathrm{~mL}$ de $\mathrm{HNO}_{3} 2 \mathrm{~N}$ e dissolvido em agitador magnético. Uma alíquota de $50 \mathrm{~mL}$ de cada amostra foi separada e adicionada 3 gotas de HF 48\%, para garantir que o elemento $\mathrm{Zr}$ permanecesse em solução.

Os padrões NIST-2711 e 694 foram analisados juntamente com as amostras a fim de comparar os valores obtidos com os valores recomendados. O controle do drift foi realizado a partir da amostra PI-41c que foi analisada juntamente as amostras do projeto, em intervalos de aproximadamente 30 minutos. O drift corresponde a descalibração do aparelho com o tempo e precisa ser corrigido para garantir a qualidade das análises.

\subsubsection{Elementos de terras raras para fosforitos}

As amostras de fosforitos foram analisadas pelo método do ICP-MS, do qual se obteve uma análise quantitativa e uma semi-quantitativa, visando os elementos de terras raras, que também foram quantificados pelo método do ICP-OES do tipo quadrupolo, modelo ELAN 6100DRC da PerkinElmer/Sciex.

Para o procedimento analítico do ICP-MS, o pó das amostras (previamente preparado) foi dissolvido por dissolução ácida em forno de microondas. Em uma alíquota de $100 \mathrm{mg}$ de amostra, adicionou-se $5 \mathrm{~mL}$ de $\mathrm{HNO}_{3}$ destilado e $15 \mathrm{~mL}$ de $\mathrm{HF}$ destilado. Efetuou-se então o ataque em forno de microondas com pressão controlada por 3 horas. Posteriormente as amostras passaram por três etapas de secagem em chapa elétrica para eliminação de HF, e então foram avolumadas para $100 \mathrm{~mL}$. 
O procedimento analítico para ICP-OES está descrito no subitem 4.3.2.

\subsubsection{Isótopos estáveis de C e O}

Para análises de isótopos de $\mathrm{C}$ e $\mathrm{O}$ foram obtidas amostras de rocha total com broca milimética. As análises foram realizadas no Laboratório de Isótopos Estáveis (NEG-LABISE) da Universidade Federal de Pernambuco (UFPE), onde o $\mathrm{CO}_{2}$ foi extraído em linha de alto vácuo após reação com ácido fosfórico (Eq. 4.3.1) a $25{ }^{\circ} \mathrm{C}$ durante três dias e analisado para isótopos de $\mathrm{C}$ e $\mathrm{O}$ em espectrômetro de massa VG Isotech SIRA II.

$$
6 \mathrm{H}^{+}+2 \mathrm{PO}_{4}{ }^{3-}+3 \mathrm{CaCO}_{3} \leftrightarrow 3 \mathrm{H}_{2} \mathrm{O}+3 \mathrm{Ca}^{2+}+2 \mathrm{PO}_{4}{ }^{3-}+3 \mathrm{CO}_{2(\mathrm{~g})} \uparrow
$$

As razões ${ }^{13} \mathrm{C} /{ }^{12} \mathrm{C}$ e ${ }^{18} \mathrm{O} /{ }^{16} \mathrm{O}$ foram mensuradas em partes por mil (\%o - Eq. 4.3.2 e 4.3.3) em relação ao padrão conhecido como VPDB (Vienna Pee Dee Belemnite - substituto da Belemnitella americana da Formação Pee Dee do Cretáceo - HOEFS, 2009; SHARP, 2007).

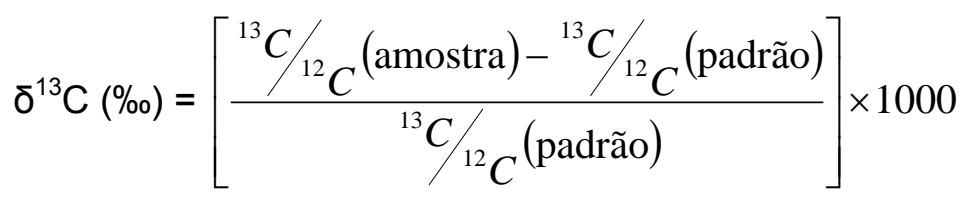

$$
\begin{aligned}
& \delta^{18} O(\%)=\left[\frac{{ }^{18} O /{ }^{16} O^{(\text {amostra })-{ }^{18} O /{ }^{16} O^{(\text {padrão })}}}{{ }^{18} O /{ }^{16} O^{(\text {padrão })}}\right] \times 1000
\end{aligned}
$$

\subsection{Mineralogia}

A mineralogia das amostras da Formação Bocaina foi em parte identificada por difração de raios- $x$, equipamento da Siemens modelo D5000. Foram analisadas 17 amostras no Laboratório de Difração de raios-x do IGc-USP. Os difratogrâmas estão apresentados no Anexo $\mathrm{A}$ e as amostras analisadas especificadas no anexo $\mathrm{C}$.

Além da difração, algumas seções delgadas foram tingidas com o corante orgânico Alizarina Vermelha $\mathrm{S}\left(\mathrm{C}_{14} \mathrm{H}_{7} \mathrm{NaO}_{7} \mathrm{~S}\right)$, a fim de diferenciar calcita de dolomita (FRIEDMAN, 1959). 


\section{FOSFORITOS: REVISÃO DOS CONHECIMENTOS}

\subsection{Ciclo do fósforo}

A formação de sedimentos fosfáticos está diretamente relacionada ao ciclo do fósforo nos oceanos. Este ciclo compreende diversos estágios, que vão desde a migração do elemento para as águas oceânicas até sua fixação e evolução diagenética nos sedimentos da bacia.

Para os oceanos atuais, a principal fonte de fósforo são os rios (BATURIN, 2003), que transportam às bacias oceânicas e marinhas o elemento sob as formas orgânica e inorgânica, tanto dissolvido ou como partículas sólidas (KHOLODOV, 2003a).

A média do conteúdo de fósforo dissolvido nas águas dos oceanos mundiais é de 62 $\mu \mathrm{g} / \mathrm{L}$, atingindo no máximo $100 \mu \mathrm{g} / \mathrm{L}$ (KHOLODOV, 2003a) e menos que $1 \mu \mathrm{g} / \mathrm{L}$ para águas superficiais durante a atividade planctônica, já que o fósforo é consumido pelo metabolismo destes organismos (BATURIN, 2003). Esses números podem atingir cerca de $300 \mu \mathrm{g} / \mathrm{L}$ de fósforo dissolvido em bacias com águas estagnadas, como no Mar Negro e Báltico (BATURIN, 2003). O fósforo é encontrado principalmente sob a forma de $\mathrm{HPO}_{4}{ }^{2-}$ mas também como $\mathrm{PO}_{4}{ }^{3-}$ e formas complexas associadas a Ca e Mg.

Outra forma comum de ocorrência de fósforo é a presente nos organismos. $O$ fitoplâncton marinho contém cerca de 0,3 a 2,0\% de fósforo e o zooplâncton de 0,05 a 1,6\% (porcentagem em peso seco). Partes de animais possuem quantidades mais elevadas, como 15 a $18 \%$ em conchas de braquiópodes, $6 \%$ em carapaças de crustáceos, $8 \%$ em ossos e $16 \%$ em escamas de peixes. No entanto, o fitoplâncton é o maior produtor de matéria orgânica nos níveis superiores dos oceanos mundiais, correspondendo a $25 \times 10^{9} \mathrm{t}$, sendo que dessa massa cerca de $53 \times 10^{6}$ t é de fósforo. A produção primária está relacionada à atividade vital do fitoplâncton, gerando cerca de 60 a $100 \mathrm{Gt}$ de carbono orgânico com o consumo de 1,5 a 2,5 Gt de fósforo por ano extraído da água do mar na zona fótica (BATURIN, 2003).

O fluxo do fósforo proveniente de águas profundas para águas rasas é estimado em aproximadamente $1,0 \mathrm{~g} / \mathrm{m}^{2}$ por ano, em zona costeira relacionada à correntes de ressurgências marinhas, e de $0,1 \mathrm{~g} / \mathrm{m}^{2}$ em outras zonas de plataforma, sopé continental e zonas pelágicas. Desta forma, o fluxo do elemento proveniente de águas profundas que atinge águas rasas em todos os oceanos é estimado em 10 a $12 \mathrm{Mt}$, ou seja, menos de $1 \%$ da massa de fósforo envolvida no ciclo biológico (BATURIN, 2003).

A distribuição do fósforo, em geral, é similar a do carbono orgânico, mas em alguns casos, pode se associar aos sedimentos enriquecidos em óxidos-hidróxidos de ferro. Nos 
sedimentos marinhos, os teores mais baixos de fósforo (menos que $0,01 \%$ ) são encontrado em calcários e diatomáceas filtradoras, enquanto os teores mais altos $(0,2$ a $0,6 \%)$ ocorrem em argilas vermelhas pelágicas e especialmente em argilas zeolíticas (BATURIN, 2003).

A distribuição lateral do fósforo em sedimentos superficiais, em geral, decresce da área de plataforma para zonas pelágicas, correspondendo à produção primária do fitoplâncton, como observado nos oceanos Atlântico e Índico. A distribuição vertical nos sedimentos não depende apenas da litologia, mas também da redistribuição diagenética do elemento. Os sedimentos das camadas superiores da costa e hemi-pelágicos são enriquecidos com fósforo em relação aos das camadas inferiores (BATURIN, 2003).

Nos oceanos atuais, o fósforo entra na zona diagenética como fosfato orgânico, detritos de ossos e coprólitos, enriquecendo, desta forma, as águas intersticiais em $\mathrm{P}_{2} \mathrm{O}_{5}$. $\mathrm{A}$ matéria orgânica rapidamente soterrada e a decomposição por ação microbiana, em geral sulfato-redutoras, tornam $\mathrm{o}$ ambiente diagenético rapidamente anóxico, permitindo o enriquecimento das águas intersticiais em fosfato dissolvido (COMPTON et al., 1994; FÖLLMI, 1996).

A difusão do elemento para as águas intersticiais é acompanhada pela mudança na alcalinidade devido à perda de $\mathrm{CO}_{2}$, formação de grãos e nódulos fosfáticos e fosfatização de coprólitos (COMPTON et al., 1994; KHOLODOV, 2003a). A subseqüente erosão e retrabalhamento dos sedimentos por correntes promovem a concentração mecânica dos nódulos, grãos, conchas e coprólitos e dá origem aos depósitos na forma que são conhecidos.

\subsection{Gênese de fosforitos}

As rochas fosfáticas sedimentares são denominadas de fosforitos quando possuem mais de $50 \%$ de minerais de fosfato (BATURIN, 2003) ou mais de $15 \%$ de $\mathrm{P}_{2} \mathrm{O}_{5}$ (PAPINEAU, 2010). São constituídas por uma variedade de minerais do grupo da apatita em especial fluorapatita ou compostos amorfos como o colofânio. A presença de $\mathrm{SiO}_{2}$ em fosforitos ocorre sob a forma de sílica ou silicatos, principalmente argilominerais, incluindo glauconita. São comuns as associações de fosforitos com enxofre, sob a forma de sulfetos, sulfatos ou com matéria orgânica. Alumínio e ferro estão principalmente associados com argilas, sulfetos e hidróxidos de ferro e alumino-fosfato (SLANSKY, 1986).

A gênese dos sedimentos fosfáticos ainda é um assunto controverso na literatura. Um dos primeiros estudos a respeito deve-se a Kazakov (1937), que formulou a hipótese de precipitação estritamente físico-química da apatita a partir da água do mar em zonas costeiras sujeitas à correntes marinhas ascendentes (upwellings). Kazakov baseou-se em 
pesquisas realizadas na década de 20, através das quais foram estimados valores entre 130 e $265 \mu \mathrm{g} / \mathrm{L}$ de fósforo dissolvido nas águas do Atlântico. Com estes valores, as águas dos oceanos seriam supersaturadas em fósforo, e a precipitação puramente química seria possível (KAZAKOV, 1937). No entanto, os valores da concentração do elemento estavam superestimados, sendo que as águas oceânicas possuem em média $62 \mu \mathrm{g} / \mathrm{L}$, atingindo no máximo $100 \mu \mathrm{g} / \mathrm{L}$ (KHOLODOV, 2003a). Desta forma, os oceanos são insaturados em fósforo sendo, portanto, inviável a precipitação orto-química da apatita.

$\mathrm{Na}$ hipótese original de Kazakov não era considerada a participação biológica no processo de deposição do fosfato. Considerava-se que o conteúdo de fósforo aumentava conforme a profundidade, sendo mínimo na zona fótica e máximo por volta de $500 \mathrm{~m}$. O fosfato precipitaria na zona plataformal, quando correntes frias e ricas em fósforo dissolvido ascendessem para águas rasas. Durante a ascensão, mudanças físico-químicas ocorreriam, incluindo o aumento de temperatura e decréscimo na pressão parcial de $\mathrm{CO}_{2}$, que ocasionariam a deposição do fosfato. No entanto, até $50 \mathrm{~m}$ de profundidade, na zona de fotossíntese, grande parte do fósforo é assimilada pelo fitoplâncton, não ocorrendo precipitação direta da apatita na superfície do mar como pensava Kazakov (SHELDON, 1981).

A hipótese quimiogênica de Kazakov foi amplamente criticada por diversos cientistas, apontando falhas ou colaborando no seu desenvolvimento. O papel da atividade biológica na precipitação dos minerais de fosfato é a principal colaboração à hipótese original. Diversos autores discutem a ação de comunidades microbianas sulfato-redutoras nos processos eodiagenéticos. Inicialmente, estas bactérias anaeróbias são responsáveis por degradar a matéria orgânica, liberando o fósforo para soluções intersticiais. Estas soluções altamente alcalinas, enriquecidas cerca de 250 vezes mais em fósforo que a água do mar (KHOLODOV, 2003a), e com baixo teor de Mg, podem resultar na formação de nódulos de fosfato (SHELDON, 1981).

De forma simplificada, a figura 5.2.1 ilustra o modelo de upwellings aplicado ao PréCambriano. A proliferação de cianobactérias na área de ressurgências marinhas produziria uma enorme quantidade de matéria orgânica, que concentra fósforo na biomassa, o que empobrece as águas superficiais e leva a diminuir a disponibilidade de oxigênio abaixo da zona fótica. Durante a decomposição da matéria orgânica na coluna d'água, o fósforo é liberado e sua concentração aumenta na zona anóxica. O fósforo é também regenerado durante a eodiagênese e pode retornar para a coluna d'água por ressurgência marinha ou concentrar-se nos sedimentos. De maneira geral, observa-se que a maior parte dos fosforitos estão relacionados a eventos transgressivos, quando há criação de novas bacias 
restritas e aumenta a entrada de nutrientes por intemperismo e upwelling (PAPINEAU, 2010).

O ambiente deposicional dos fosforitos é muito variado, e isso se reflete na variedade de litologias em que são encontrados (Figura 5.2.1), desde fácies de águas profundas, como folhelhos e formações ferríferas bandadas, até fácies de águas rasas, como argilitos, calcários, chert e arenitos (PAPINEAU, 2010).

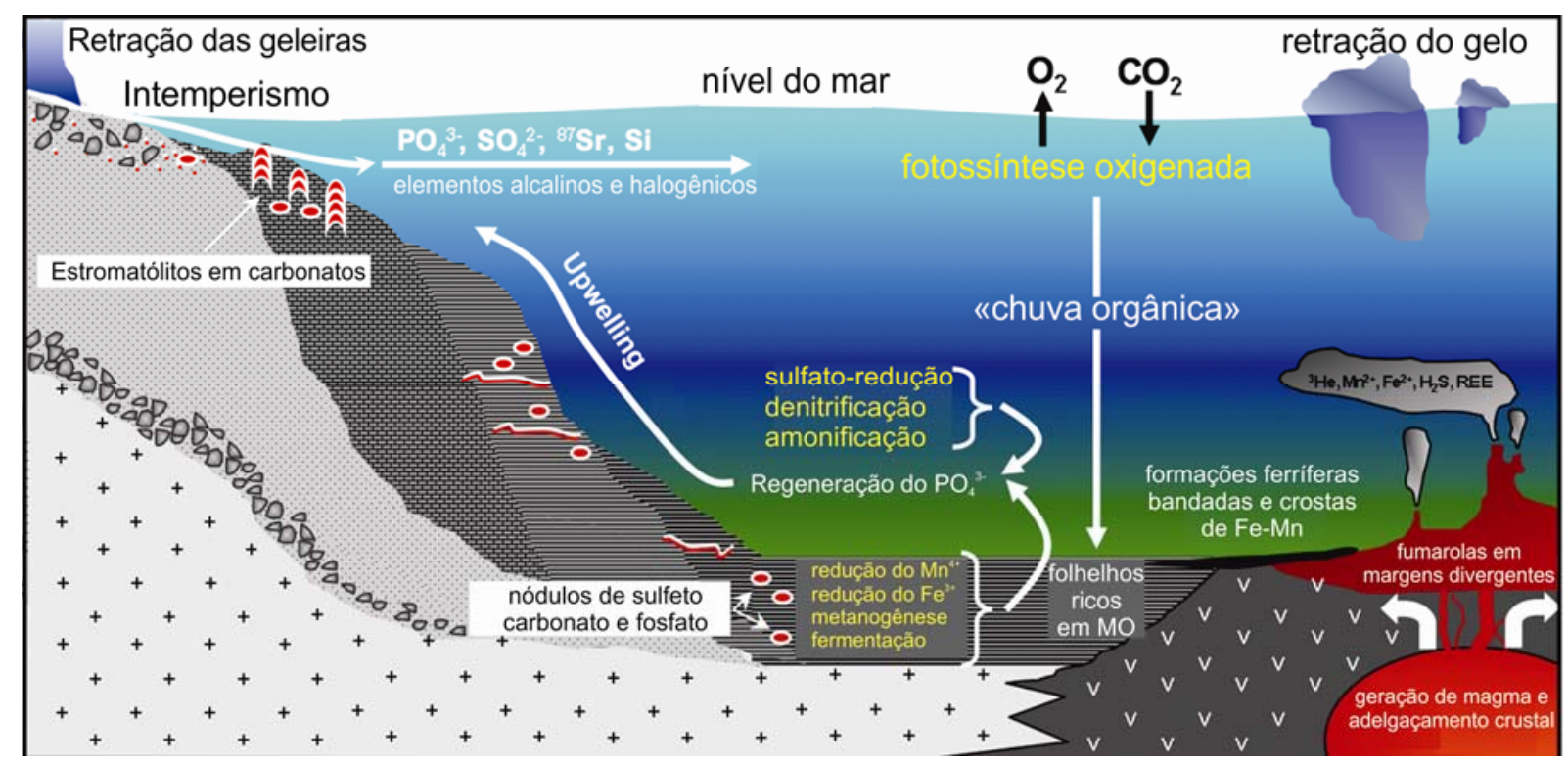

Figura 5.2.1 - Ilustração simplificada do modelo fosfogenético de ressurgências marinhas. As acumulações de fosfato em rochas sedimentares Pré-Cambrianas são representadas, em vermelho, como: círculos (concreções e nódulos), linhas curvas (camadas finas), colunas (estromatólitos) e pequenos pontos (disseminação fina). Vários litotipos estão representados, incluindo rochas vulcânicas ("v"), granitóides ("+"), formações ferríferas bandadas (em preto), folhelhos (listras horizontais), calcários ("tijolinhos"), arenito (pontilhado) e conglomerado (polígonos semi-circulares). Os principais processos metabólicos estão indicados em amarelo. As cores em degradê na coluna d'água representam: azul claro (zona fótica - óxica); azul escuro (zona redox transicional) e verde (zona anóxica) (modificado de PAPINEAU, 2010).

No entanto, a maior parte da matéria orgânica, soterrada em sedimentos marinhos, ocorre em área de não-upwelling, onde sedimentos deltáicos, estuarinos e de plataforma são depositados. Nesses ambientes, as águas intersticiais podem se enriquecer em fosfato dissolvido devido a sua liberação durante a degradação da matéria orgânica por comunidades microbianas anaeróbicas (BERNER, 1990; PAPINEAU, 2010).

Assim, há outros modelos fosfogenéticos que não envolvem diretamente correntes de ressurgências marinhas, como os propostos por Schwennicke et al. (2000) que incluem bacias em mares epicontinentais e sedimentação relacionada a atol. A exemplo da Polinésia Francesa, onde lagunas são repletas de cianobactérias entre outras formas de vida microbianas devido ao constante suprimento de nutrientes, inclusive o fósforo, por endo- 
upwelling (correntes de ressurgências marinhas que alcançariam as lagunas quando o nível do mar encontrar-se-ia elevado). A grande quantidade de matéria orgânica torna a água de fundo anóxica, que conseqüentemente preserva este material. As águas intersticiais são enriquecidas em fósforo, favorecendo a precipitação in situ da apatita autigênica. Observase também, a influência das cianobactérias como sítio de nucleação do mineral, além do enriquecimento secundário devido à dissolução e reprecipitação do fosfato (SCHWENNICKE et al., 2000).

O modelo proposto acima poderia ser aplicado também ao Pré-Cambriano, considerando que haveria grande disponibilidade de matéria orgânica proveniente de comunidades microbianas que dominaram os ambientes marinhos da época, devido à ausência de predadores. Esse modelo adéqua-se aos modelos paleogeográficos nos quais não há possibilidade de haver ressurgências marinhas, como no caso de bacias intracontinetais rasas, a exemplo da bacia neoproterozóica de Irecê, Bahia, na qual são encontradas rochas fosfáticas (MISI; KYLE, 1994). A interpretação para a gênese dessas rochas poderia ser um modelo semelhante ao dos atóis da Polinésia Francesa.

Outro modelo de fosfogênese, também baseado em correntes de ressurgências marinhas, é proposto por Compton et al. (1994). O ambiente deposicional da Formação Hawthorn (Mioceno), Flórida, é interpretado pelos referidos autores como um ambiente lagunar raso, no qual haveria a formação de dolomita organogênica e sedimentos fosfáticos associados durante a eodiagênese, em ambiente com excesso de matéria orgânica soterrada em eventos de subida do nível do mar. A degradação da matéria orgânica seria responsável por mudanças geoquímicas nas águas intersticiais, que permitiriam a formação destes minerais (Figura 5.2.2). Assim, haveria difusão do $\mathrm{PO}_{4}{ }^{3-}$ para as águas intersticiais, além do nível do mar alto ou em ascensão, o que favoreceria a ação de correntes de ressurgências marinhas, enriquecendo ainda mais as águas em fosfato, permitindo a formação de sedimentos fosfáticos tanto em zonas sub-óxicas como anóxicas (Figura 5.2.2A).

Subseqüentemente, com o soterramento contínuo, estes sedimentos alcançariam níveis anóxicos, já propriamente na zona de sulfato-redução, o que permitiria a formação de cristais de dolomita. A formação de dolomita por processos de sulfato-redução são descritas em ambientes modernos e em culturas de laboratório (VASCONCELOS et al., 1995; VASCONCELOS; MCKENZIE, 1997; WARTHMANN et al., 2000; VAN LITH et al., 2003 WARTHMANN et al., 2000; VAN LITH et al., 2003), como discutido no capítulo seguinte. Após a formação destes sedimentos, o rebaixamento do nível do mar seria responsável pelo retrabalhamento e concentração dos mesmos (Figura 5.2.2B). 


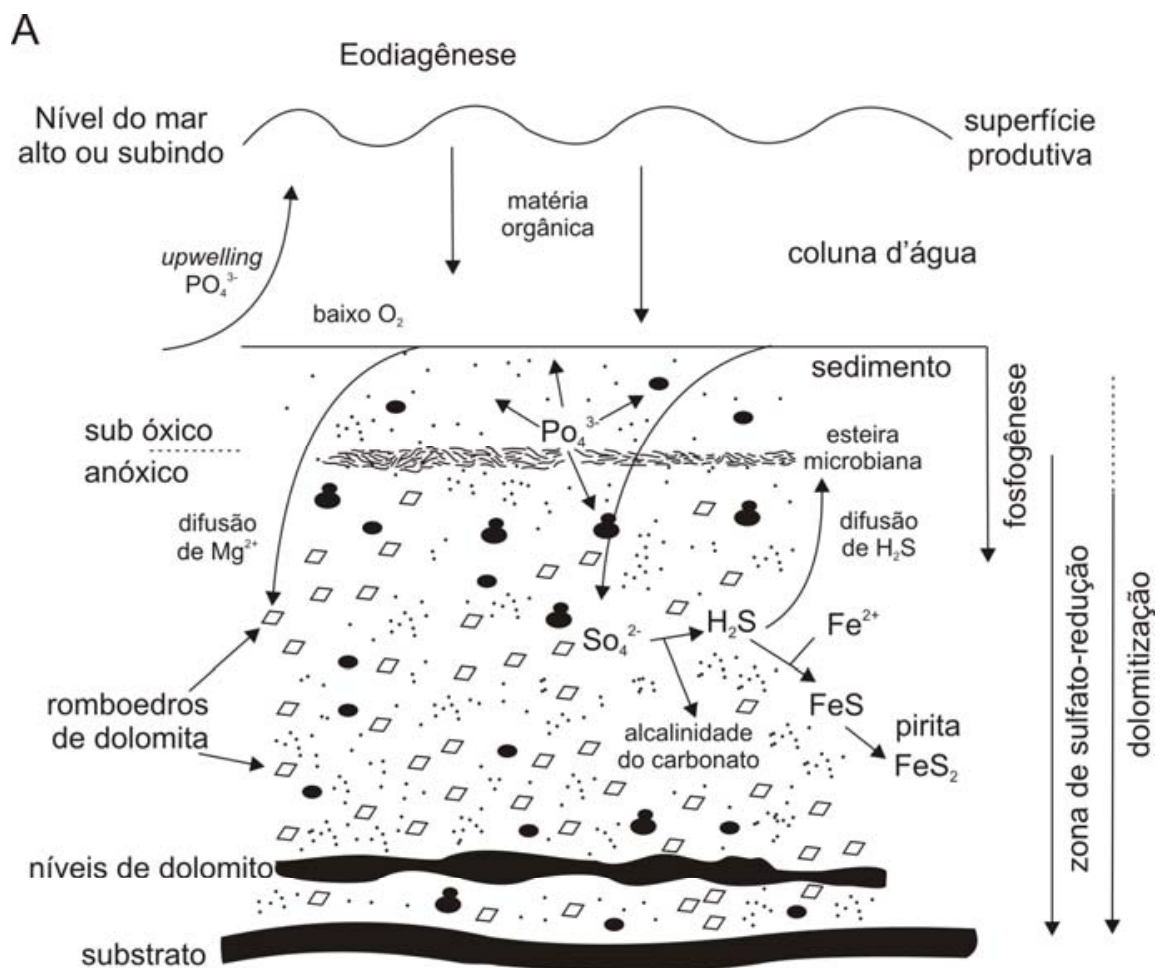

B

Retrabalhamento

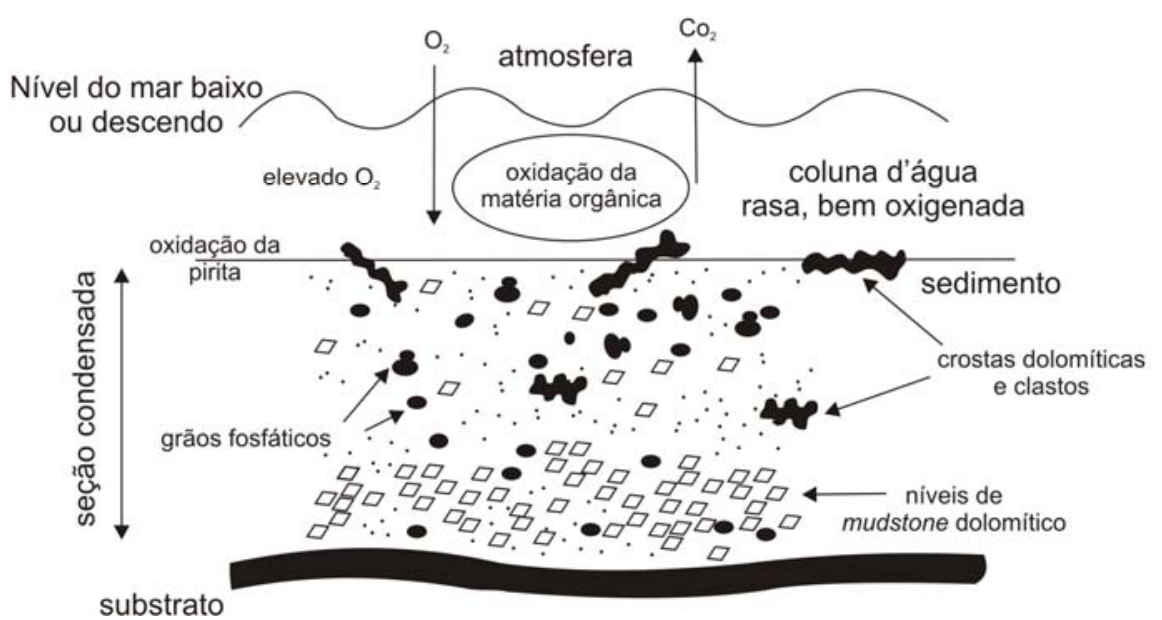

Figura 5.2.2 - Cenário proposto para a gênese da Formação Hawthorn (Flórida): A) durante a eodiagênese e B) deposição final depois do retrabalhamento sedimentar. Aumento na taxa de soterramento da matéria orgânica devido ao aumento da superfície de produtividade, resultado da intensificação das correntes de ressurgências marinhas durante períodos de nível do mar alto ou subindo. A degradação da matéria orgânica nos sedimentos leva a formação de fosforito e dolomito. Os dolomitos são formados inicialmente abaixo da zona de formação de fosforito, amplamente na zona de sulfato-redução, na forma de romboedros dispersos e cimento preenchendo os poros. A dolomitização é promovida pela dissolução de conchas aragoníticas e de calcita magnesiana, difundindo o $\mathrm{Mg}$, removendo os íons de sulfato e aumentando a alcalinidade do carbonato. $\mathrm{H}_{2} \mathrm{~S}$ produzido durante a sulfato-redução reage com os íons de Fe para formar pirita ou difunde para esteiras microbianas acima, que oxidam $\circ \mathrm{H}_{2} \mathrm{~S}$, transformando-o novamente em sulfato. $\mathrm{O}$ retrabalhamento dos sedimentos durante a regressão marinha concentra os grãos de fosforito e dolomito, exumando e expondo os níveis dolomíticos, removendo a matéria orgânica e pirita por oxidação (modificado de COMPTON et al., 1994). 
Observa-se que a formação de fosforitos, tanto em ambientes antigos como recentes, é uma combinação de diversos fatores que envolvem processos oceanográficos, sedimentológicos, diagenéticos e de erosão e ressedimentação (SHELDON, 1981).

Kholodov (2003b) sumarizou seis processos básicos para a formação de um depósito de sedimentos fosfáticos: (i) intensidade do fluxo de fósforo do continente e dos níveis profundos dos oceanos e consumo pela biomassa primária, e subseqüente morte e decantação no fundo da bacia, (ii) desenvolvimento de condições necessárias para o soterramento da matéria orgânica, rica em fósforo, nos sedimentos mais profundos, (iii) relativa ausência de material terrígeno silicoso ou carbonático, (iv) transformação diagenética da matéria orgânica e dissolução do fósforo nas águas intersticiais e subseqüente precipitação do fosfato, (v) posterior retrabalhamento do nível fosfático com remoção de terrígenos finos (material argiloso) e formação de nódulos fosfáticos, e (vi) infiltração de águas meteóricas, formação de elúvio e enriquecimento supergênico em zona de oxidação do fosfato.

\subsection{Fosforitos no tempo geológico: Neoproterozóico}

A distribuição dos fosforitos no tempo geológico é um ponto questionado por muitos pesquisadores. Uma das questões é que a origem de grandes depósitos fosfáticos aparenta ser episódica no registro geológico e poderia estar relacionada com fases de separação continental, formação de oceanos, eventos glaciais e períodos de mudanças no ciclo biogeoquímico dos oceanos (COOK; MCELHINNY, 1979; SHIELDS et al., 2000; PAPINEAU, 2010).

Cook \& McElhinny (1979) compilaram dados de 216 depósitos de fosfato sedimentar e identificaram seis intervalos de tempo principais de fosfogênese: o limite PréCambriano/Cambriano, os períodos Ordoviciano, Permiano, Jurássico, e os limites Cretáceo Superior-Eoceno e Mioceno-Recente (Figura 5.3.3).

Estudos posteriores também apontam para dois principais eventos de formação de depósitos gigantes de fosforitos: um no Ediacarano/Cambriano Médio (<590-510 Ma) e outro no Mioceno/Recente (75-0 Ma) (NOTHOLT et al., 1989), apesar de grandes jazidas também serem conhecidas no Cretáceo Médio e Jurássico do leste Europeu, Ordoviciano, Carbonífero e Permiano nos EUA (SHIELDS et al., 2000). 


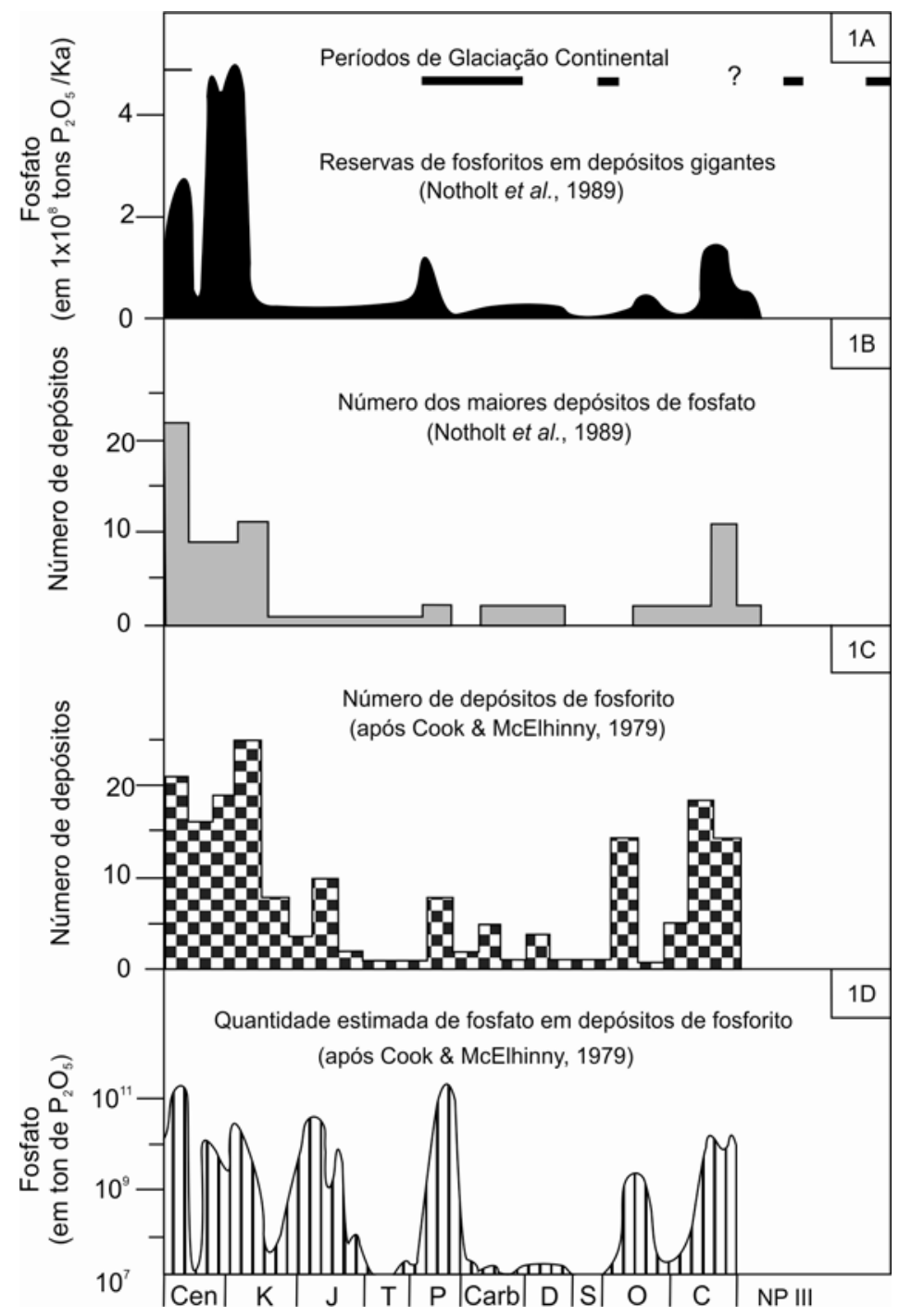

Figura 5.3.3 - (1A) Abundância estimada de fosforito (em toneladas de $\mathrm{P}_{2} \mathrm{O}_{5}$ ) no tempo geológico, baseada nos maiores depósitos de fosforito do mundo (NOTHOLT et al., 1989) e a relação com períodos de glaciação (barras pretas horizontais no topo da figura). (1B) Número estimado de depósitos fosfáticos (avaliação baseada na reserva potencial) (NOTHOLT et al., 1989). (1C) Número estimado de depósitos fosfáticos para o Fanerozóico (após COOK; MCELHINNY, 1979); (1D) Abundância estimada de fosfato em depósitos fosfáticos (em tons de $\mathrm{P}_{2} \mathrm{O}_{5}$ ), em escala logarítimica (após COOK; MCELHINNY, 1979).

Notavelmente, a maior parte dos fosforitos neoproterozóicos ocorre durante períodos pós-glaciais (PAPINEAU, 2010). Exemplos são encontrados na América do Norte e do Sul, África, Ásia e Austrália (COOK; SHERGOLD, 1984), sendo que grande parte está sobre tilitos, a exemplo dos depósitos fosfáticos do Grupo Bambuí (MISI et al., 2007).

A possível conexão de eventos de fosfogênese com glaciação continental é sugerida devido ao aumento da circulação oceânica vertical após os períodos glaciais, o que poderia incrementar as correntes de ressurgências marinhas, de forma parecida com o que ocorre nos oceanos atuais. Para o limite do Neoproterozóico/Cambriano, acredita-se que após o período de Snowball Earth, durante o qual as águas oceânicas permaneceram estagnadas e 
puderam concentrar elevada quantidade de nutrientes dissolvidos nas águas profundas e anóxicas, houve um período de vigorosa circulação oceânica, que pode ter conduzido a formação de fosforitos (SHIELDS et al., 2000; PAPINEAU, 2010). Para os depósitos do Cretáceo Superior e Cenozóico Inferior, períodos significativos de fosfogênese, há evidências sutis de glaciações (SHIELDS et al., 2000).

Como a maior fonte de fósforo para os oceanos são os rios (BATURIN, 2003; KHOLODOV, 2003a), eventos de formação de depósitos gigantes de fosforito poderiam estar associados com períodos de aumento do intemperismo continental (PAPINEAU, 2010). O limite do Pré-Cambriano-Cambriano e o período Cretáceo, apontados como os dois grandes momentos de fosfogênese global, são marcados por intenso rifiteamento e soerguimento de cadeias montanhosas (SHIELDS et al., 2000; PAPINEAU, 2010). Outro fator pode ser a circulação hidrotermal, que tende a remover o fósforo dos oceanos. Taxa de expansão dos oceanos pode ter influenciado significativamente a concentração de fósforo na água do mar (SHIELDS et al., 2000).

Os fosforitos do limite Pré-Cambriano/Cambriano apresentam diversas evidências da participação biológica na sua formação, sendo a mais notável delas os estromatólitos fosfáticos e as estruturas multicelulares preservadas na Formação Doushantuo, China (CHEN et al., 2003). Muitos autores apontam para mudanças químicas ocorridas nas águas dos oceanos, neste período, em parte iniciadas pelo aparecimento dos primeiros metazoários pelágicos, como responsáveis pelo aumento da quantidade de fósforo nos sedimentos (SHIELDS et al., 2000). A rápida decantação dos pellets fecais (registro mais antigo de digestão, um pouco mais recentes que $600 \mathrm{Ma}$ ) pode ter ajudado a limpar a superfície da água do mar dos detritos em suspensão, da mesma forma que organismos filtrantes, como as esponjas, promovendo o aumento da fotossíntese e a oxigenação das águas e auxiliando na transferência de fósforo para a interface sedimento/água. (SHIELDS et al., 2000).

Além desses fatores, o advento da bioturbação contribuiu para a concentração mecânica de fósforo nos sedimentos além da oxigenação no estágio inicial da diagênese e a oxidação do carbono orgânico, e conseqüentemente maior concentração de fósforo dissolvido nas águas intersticiais (GLENN, 1990; SHIELDS et al., 2000).

Shields e colaboradores (2000), a partir dessas observações, definem dois períodos distintos próximos ao limite Pré-Cambriano/Cambriano, para geração de depósitos fosfáticos: o primeiro, inicial, entre 590-555 Ma, corresponde ao surgimento dos primeiros animais macroscópicos, pellets fecais e a bioturbação. Já o segundo e principal período seria entre 545-525 Ma e corresponde ao advento da bioturbação penetrativa (característica do Fanerozóico) e o aumento da diversidade das macrofaunas durante a Explosão 
Cambriana. Os autores concluem que as inovações biológicas decorrentes do aparecimento e evolução da primeira fauna de metazoários têm papel fundamental na formação de depósitos fosfáticos gigantes no limite Pré-Cambriano/Cambriano, justificando assim a ausência de depósitos significativos antes de $600 \mathrm{Ma}$.

Os eventos ocorridos no Neoproterozóico, listados previamente como possíveis responsáveis pela fosfogênese, sugerem forte conexão entre rifiteamento seguidos por períodos de greenhouse, que conseqüentemente aumentariam o intemperismo químico e aumentariam o aporte de fósforo para os oceanos, permitindo intensa proliferação de cianobactérias, responsáveis pelo acúmulo de oxigênio na atmosfera, e que culminou, finalmente, no aparecimentos de organismos multicelulares que respiravam oxigênio (PAPINEAU, 2010).

\subsection{Elementos de terras raras em fosforitos}

Os elementos de terras raras (ETR) compreendem um grupo de 15 elementos que abrange do ${ }_{57} \mathrm{La}$ ao ${ }_{71} \mathrm{Lu}$ quimicamente semelhantes (HOLSER, 1997). São amplamente empregados em estudos de geoquímica marinha, devido a sua distribuição homogêna a partir da qual é possível deduzir sua fonte nos depósitos sedimentares (ELDERFIELD; GREAVES, 1982). São elementos trivalentes, porém o Eu e o Ce possuem estados de oxidação bivalentes e tetravalentes respectivamente, em função das condições oxiredutoras do ambiente deposicional (ELDERFIELD; GREAVES, 1982; HOLSER, 1997; MACLEOD; IRVING, 1996; SHIELDS; STILLE, 2001; CHEN et al., 2003).

$\mathrm{Na}$ água do mar, os ETR possuem concentrações extremamente baixas, da ordem de 3 a $70 \times 10^{-12} \mathrm{~mol} / \mathrm{kg}$, caracterizando-se por concentrações relativamente mais baixas nas águas superficiais e progressivo enriquecimento em profundidade, cujo máximo das concentrações é atingido em torno de $1000 \mathrm{~m}$ de profundidade (ELDERFIELD; GREAVES, 1982; HOLSER, 1997).

Para o estudo de rochas sedimentares pelíticas, utiliza-se a concentração normalizada para o folhelho PAAS (média da concentração de ETR de 23 folhelhos pósarqueanos da Austrália) (MCLENNAN, 1989), que para a água do mar reflete um leve enriquecimento em ETR pesados relativamente aos leves, já que os ETR leves possuem tendência de ficarem adsorvidos em partículas em suspensão (SHIELDS; STILLE, 2001).

Os rios são a principal fonte de ETR para a água do mar, enquanto as outras fontes potenciais (fluidos hidrotermais das cadeias meso-oceânicas e cinzas vulcânicas derivadas de arcos de ilhas) são subordinadas e de importância local (HOLSER, 1997). 
As concentrações, padrões de ETR e anomalias positivas ou negativas de Ce e Eu em rochas sedimentares marinhas são usualmente indicadores de ambientes deposicionais e pós-deposicionais (MURRAY et al., 1990; CHEN et al., 2003). O Ce é um importante indicador de paleo-oceano redox, enquanto o Eu é pouco móvel em condições diagenéticas normais. Entretanto, a distribuição de ETR pode ser subseqüentemente alterada por variações pós-deposicionais ou superficiais (SHIELDS; STILLE, 2001).

\section{Anomalias de $\mathrm{Ce}$}

A anomalia de Ce é representada pela equação 5.4.1 (ELDERFIELD; GREAVES, 1982):

$$
\mathrm{Ce}_{\text {anomalia }}=\log \left[3 \mathrm{Ce}_{\mathrm{n}} /\left(2 \mathrm{La}_{\mathrm{n}}+\mathrm{Nd}_{n}\right)\right]
$$

Chen et al. (2003) consideram a razão $\mathrm{Ce} / \mathrm{Ce}^{*}$ como sendo (equação 5.4.2):

$$
\mathrm{Ce} / \mathrm{Ce}^{*}=3 \mathrm{Ce}_{n} /\left(2 \mathrm{La}_{\mathrm{n}}+\mathrm{Nd}_{n}\right)
$$

enquanto a anomalia de Ce como (equação 5.4.3):

$$
\mathrm{Ce}_{\text {anomalia }}=\left(\mathrm{Ce} / \mathrm{Ce}^{*}\right)
$$

Onde $\mathrm{Ce}^{*}$ representa o valor da concentração do elemento no estado de oxidação trivalente esperado, por interpolação com os elementos vizinhos. Já Shields \& Stille (2001) consideram $\mathrm{Ce}_{\text {anomalia }}=\mathrm{Ce} / \mathrm{Ce}^{*}$, representados pela mesma expressão.

Segundo Wright et al. (1987), são consideradas anomalias negativas de Ce quando $\mathrm{Ce}_{\text {anomalia }}<-0,10$ e anomalias positivas quando $\mathrm{Ce}_{\text {anomalia }}>-0,10$.

As anomalias negativas de $\mathrm{Ce}$ estão relacionadas principalmente às águas oceânicas oxigenadas, já que ocorre a remoção do elemento da coluna d'água devido a oxidação do $\mathrm{Ce}^{3+}$ e precipitação como $\mathrm{Ce}^{4+}$ (insolúvel) junto a outros metais multivalentes como o ferro e o manganês (WRIGHT et al., 1987; MURRAY et al., 1990; SHIELDS; STILLE, 2001). Estas anomalias podem ser associadas também com paleo-oceanos não estratificados com constante circulação de águas oceânicas e oxigenação das mesmas (Figura 5.4.1). No entanto, o empobrecimento de Ce nas águas oceânicas não depende apenas do potencial de oxidação, mas também da atividade microbiana como catalisador da oxidação do $\mathrm{Ce}^{3+}$, bem como pH e profundidade (SHIELDS; STILLE, 2001).

Em relação às anomalias positivas de $\mathrm{Ce}$ ou valores normais indicam ambientes diagenéticos subóxidos a anóxicos, nos quais há predominância do $\mathrm{Ce}^{3+}$ em solução na coluna d'água (WRIGHT et al., 1987; MAZUMDAR et al., 1999b) (Figura 5.4.1). No modelo de oceano estratificado, águas profundas e anóxicas ricas em ${ }^{12} \mathrm{C}$ e $\mathrm{P}$ dissolvidos, devido à 
matéria orgânica preservada, contém também $\mathrm{Ce}^{3+}$ dissolvido. Quando essas águas ascendem por meio das ressurgências marinhas, entram em contato com águas oxigenadas, então o excesso de Ce é removido da água através da precipitação sob a forma insolúvel de $\mathrm{Ce}^{4+}$. Devido a esta reação de oxidação, as águas da zona oxidada são rapidamente empobrecidas em $\mathrm{Ce}$, resultando em uma anmolia negativa do elemento, enquanto a zona anóxica permanece com anomalia positiva do elemento $\left(\mathrm{Ce}^{3+}\right.$ dissolvido na coluna d'água) (Figura 5.3.1) (MAZUMDAR et al., 1999b).

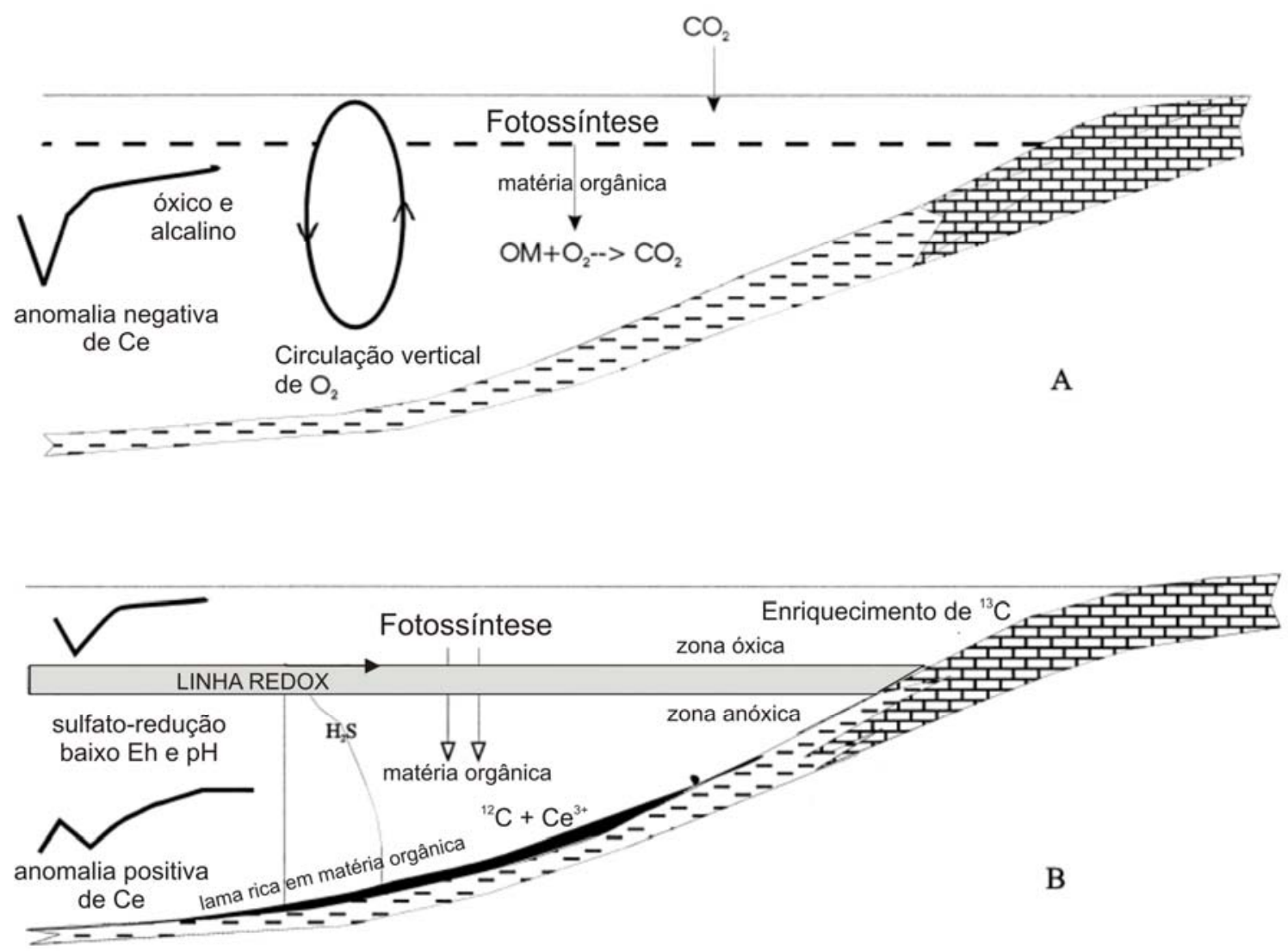

Figura 5.4.1 - Representação esquemática do modelo paleo-oceanográfico para explicação da gênese do reservatório de fósforo dissolvido em bacias oceânicas do fim do Proterozóico. (A) Oceanos não estratificados apresentam circulação vertical normal de oxigênio para partes profundas da bacia com anomalias negativas de Ce. (B) Oceanos estratificados, com a coluna de água anóxica caracterizada por baixo $\mathrm{Eh}$ e $\mathrm{pH}$ devido a sulfato-redução $\left(\mathrm{H}_{2} \mathrm{~S}, \mathrm{P}\right.$ dissolvido e $\left.{ }^{12} \mathrm{C}\right)$. Condições de baixo Eh e $\mathrm{pH}$ facilitam a transformação redutora de $\mathrm{Ce}^{4+} \mathrm{em} \mathrm{Ce}^{3+}$ solúvel, permitindo desse modo o enriquecimento da coluna d'água anóxica em $\mathrm{Ce}$ (anomalia positiva da $\mathrm{Ce}$ ). A linha redox é a zona de separação entre as partes oxidadas e anóxicas do oceano estratificado (modificado de MAZUMDAR et al., 1999a).

Em geral, os fosforitos apresentam variedade de anomalias de Ce e diferente padrão de distribuição de ETR, devido à variação na composição, quantidade de detritos associados, ambientes diagenéticos e idade (Figura 5.4.2). Como observado na figura 5.4.2, fosforitos pós-Jurássicos apresentam anomalia negativa de Ce e enriquecimento em ETR pesados (SHIELDS; STILLE, 2001), enquanto fosforitos plataformais do Recente ao final do 
Quaternário raramente apresentam alguma anomalia de Ce (MAZUMDAR et al., 1999b). Nódulos ou crostas fosfáticas associadas à precipitação ferro-magnesiana apresentam anomalias positivas de Ce (SHIELDS; STILLE, 2001).

Já as rochas fosfáticas sedimentares neoproterozóicas-cambrianas, apresentam, em geral, empobrecimento em ETR leves e pesados e anomalias negativas de Ce (Figura 5.4.2). Como exemplo, o fosforito da Formação Doushantuo apresenta anomalias negativas de Ce que são interpretadas como a mudança do ambiente deposicional de anóxico para oxidante durante o aparecimento das primeiras faunas metazoárias (Fauna de Ediacara) e as concentrações de ETR indicam a composição original da água oceânica, estando pouco alterada pela diagênese e intemperismo (CHEN et al., 2003). Em relação aos fosforitos da Formação Tal Inferior, na Índia, as anomalias negativas de Ce indicam rápida remoção do elemento por correntes de ressurgências marinhas ricas em $\mathrm{P}$ para águas oxidantes, ocasionando o empobrecimento de Ce nas águas.
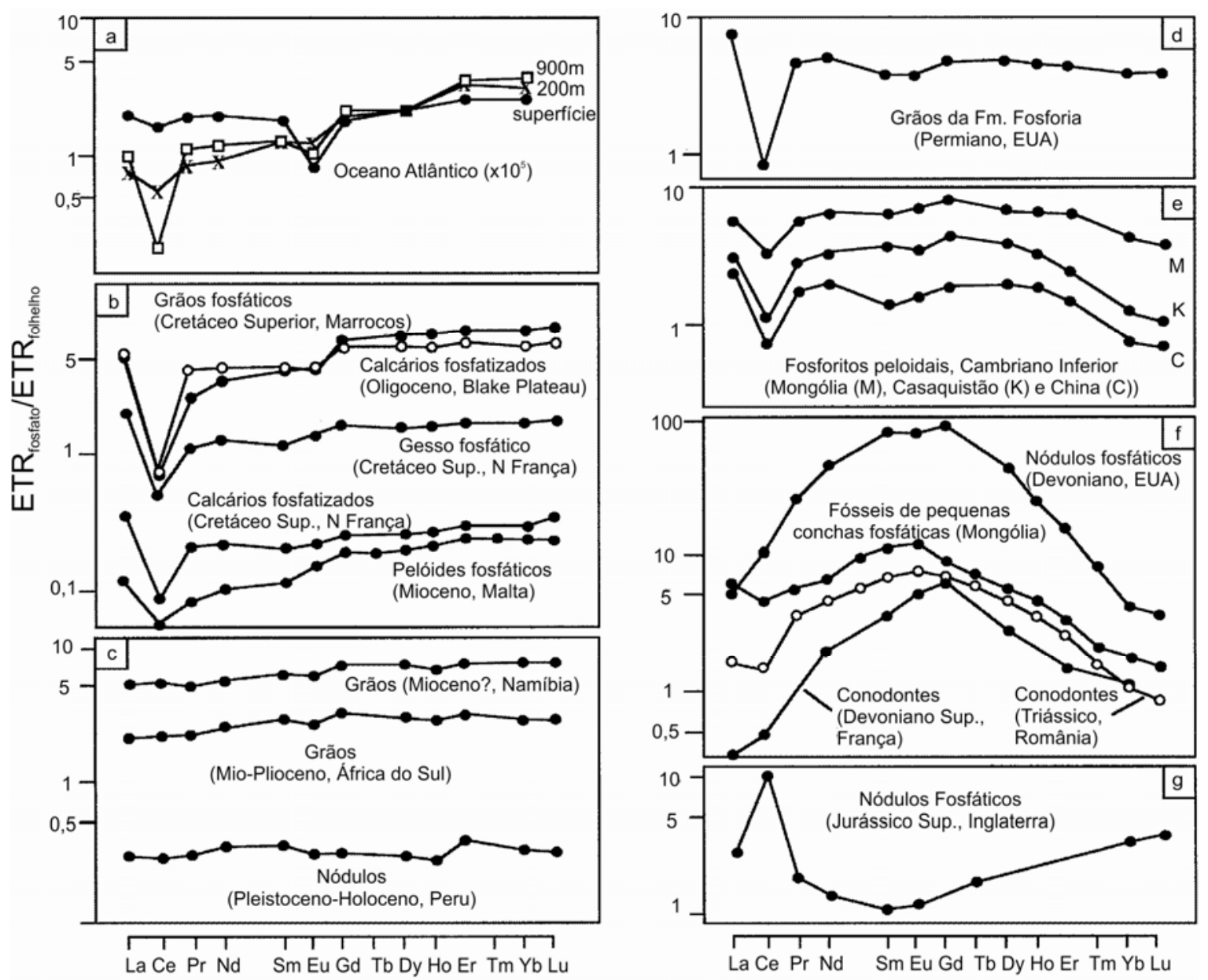

Figura 5.4.2 - Distribuição dos ETR (normalizados para o folhelho PAAS) para: (a) água do Oceano Atlântico moderno (ELDERFIELD; GREAVES, 1982) e fosforitos/partículas fosfáticas mundiais - (b, c, d, g) para grãos, nódulos e calcários fosfáticos; (e) fosforitos peloidais e (f) fósseis fosfáticos (modificado de SHIELDS; STILLE, 2001). 


\subsection{Exemplos de ocorrências brasileiras}

Os principais depósitos econômicos de fosfato explorados no Brasil são de origem ígnea, associados com complexos intrusivos alcalinos (SOUZA, 2001). Em termos mundiais, são considerados menos comuns e constituem depósitos relativamente menores e de teores mais baixos de $\mathrm{P}_{2} \mathrm{O}_{5}$.

As ocorrências de rocha fosfática sedimentar no Brasil são encontradas em unidades cretáceas da Bacia Paraíba nos estados de Pernambuco e Paraíba (Fosfato de Olinda) (DUARTE; KRAUSS, 1978; FREIRE, 2003), em seqüência metassedimentar cambriana de Itataia, no Ceará, associadas à mineralizações de urânio (AMARAL, 1997; FREIRE, 2003) e nas unidades pré-cambrianas do Grupo Una, Bahia (MISI; KYLE, 1994), e os depósitos de Rocinha e Lagamar, da base do Grupo Vazante, em Minas Gerais (NOGUEIRA, 1993; DARDENNE et al., 1997).

A jazida de Pernambuco, informalmente chamada de "Fosfato de Olinda", já era conhecida desde a década de 40. Está inserida na sucessão carbonática transgressiva da Formação Gramame, Bacia Paraíba, estendendo-se por uma faixa descontinua pela região metropolitana de Recife (REZENDE, 1994). O minério caracteriza-se por cores amareladas, branca, cinza e preta, constituído por grânulos fosfáticos, coprólitos e moldes de foraminíferos e moluscos, além de matriz e cimento (DUARTE; KRAUSS, 1978). O ambiente de sedimentação proposto é de plataforma continental, com comunicação para mar aberto e sujeita à ressurgências marinhas, recoberta em evento transgressivo por águas quentes e salinidade normal, propícias ao desenvolvimento da vida planctônica e bentônica (DUARTE; KRAUSS, 1978).

A ocorrência fosfática de Itataia, no município de Santa Quitéria, CE, corresponde ao único depósito de fosfato associado com mineralizações de urânio no Brasil. Está incluída na seqüência metassedimentar cambriana de Itataia, de natureza transgressiva, cujo topo corresponde a mármores calciticos com matéria orgânica e dolomíticos que hospedam a mineralização urano-fosfática (FREIRE, 2003). A interpretação da gênese do depósito ainda é controversa, mas admite-se que a concentração do fósforo ocorreu por remobilição e acumulação em depressões cársticas. O urânio associado ao fosfato pode ser produto de condições redutoras do ambiente plataformal de deposição. Desta forma, o minério de fosfato e urânio pode ser considerado supergênico (AMARAL, 1997).

A ocorrência neoproterozóica de rocha fosfática sedimentar de Irecê, Bahia, encontra-se inserida na seqüência carbonática marinha do Grupo Una composta por calcários, calcários dolomíticos e siltitos na porção basal, que gradam verticalmente para dolomitos e dolomito silicificado (MISI; KYLE, 1994). As mineralizações primárias ocorrem 
nas camadas de estromatólitos e estão associadas às colunas de laminações microbianas. A mineralização supergênica é constituída de fragmentos da mineralização primária, formados pela ação do intemperismo sobre o minério primário, sendo enriquecido em $\mathrm{P}_{2} \mathrm{O}_{5} \mathrm{e}$ empobrecido em MgO (MONTEIRO et al., 1997). O modelo genético proposto por Misi \& Kyle (1994) para o fosforito de Irecê sugere que o enriquecimento das águas em fosfato deve-se a degradação microbiana da matéria orgânica das cianobactérias em ambiente redutor. Não é proposto o modelo de ressurgências marinhas, devido à natureza intracratônica da bacia com acesso restrito às águas profundas.

As ocorrências de rocha fosfática de Rocinha e Lagamar, situadas no noroeste do estado de Minas Gerais, estão inseridas na seqüência metassedimentar neoproterozóica do Grupo Vazante (NOGUEIRA, 1993). O minério está associado a ardósias carbonosas e carbonáticas na forma de fosfarenito e fosfalutito (DARDENNE et al., 1997). A gênese destes fosforitos está relacionada à evolução da matéria orgânica em condições físicoquímicas transicionais entre ambientes redutor e oxidante, em mar profundo de águas frias (DARDENNE et al., 1997). Os sedimentos fosfáticos foram depositados na borda de uma plataforma continental de margem continental passiva. A precipitação fosfática marinha foi provavelmente intermediada por cianobactérias (NOGUEIRA, 1993). 


\section{DOLOMITOS: REVISÃO DOS CONHECIMENTOS}

Dolomitos são rochas carbonáticas formadas por mais de $50 \%$, em peso, do mineral dolomita [CaMg $\left(\mathrm{CO}_{3}\right)_{2}$ ] (LEIGHTON; PENDEXTER, 1962). A origem do termo dolomita esta relacionada ao geólogo e mineralogista francês Déodat de Dolomieu (1750-1802) a quem é atribuída à descoberta do mineral, na região alpina italiana conhecida como Tirol. Durante uma excursão de campo para a região, Dolomieu reconheceu a ocorrência de um tipo incomum de rocha carbonática, que se assemelhava ao calcário, porém efervescia muito pouco ao ácido clorídrico (DE DOLOMIEU, 1791 apud MCKENZIE; VASCONCELOS, 2009). Devido à alta resistência do dolomito ao intemperismo químico, os dolomitos do Tirol, que mais tarde receberiam o nome de Dolomite Mountains, destacam-se como uma feição proeminente na paisagem, despertando o interesse de gerações de cientistas em entender a gênese de tão expressiva concentração de rocha constituída de carbonato de cálcio e magnésio.

Passados mais de 200 anos da descoberta de Dolomieu, este tópico ainda é foco de muitos estudos e debates geológicos, e a gênese dos dolomitos, conseqüentemente do mineral dolomita, permanece ainda como um dos enigmas da geologia conhecido como o "Problema Dolomito" (MCKENZIE, 1991; WARREN, 2000).

O fato dos dolomitos serem abundantes no registro sedimentar do Pré-Cambriano e Paleozóico, freqüentemente associados com estruturas microbianas, mas raramente serem encontrados em ambientes sedimentares modernos (GIVEN; WILKINSON, 1987; MCKENZIE; VASCONCELOS, 2009), somado ao fato de não conseguir sintetizar o mineral dolomita em experimentos físico-químicos de laboratório, diretamente a partir da água do mar, sob condições de pressão e temperatura da superfície do planeta, suportaram por séculos este enigma.

Apesar de não se conseguir sintetizar dolomita em laboratório, sob condições normais de temperatura e pressão, qualquer sólido de carbonato de cálcio é imediatamente dolomitizado (LIPMANN, 1973). Contraditoriamente, as águas dos mares modernos são supersaturadas em dolomita, no entanto, nem precipitação nem dolomitização por substituição ocorrem atualmente, o que conduziu à interpretação de que a precipitação não ocorre em função da presença de barreiras cinéticas (WRIGHT, 1997; 2000).

Os inibidores cinéticos para formação de dolomita em condições de águas superficiais foram postulados como: (a) alta energia de hidratação do cátion $\mathrm{Mg}^{2+}$ (LIPMANN, 1973; TUCKER; WRIGHT, 1990); (b) baixa atividade do ânion $\mathrm{CO}_{3}{ }^{2-}$ (LIPMANN, 1973) e (c) presença, mesmo em pequenas concentrações, de íon $\mathrm{SO}_{4}{ }^{2-}$ (BAKER; KASTNER, 1981). O cátion de magnésio tende a permanecer ligado aos átomos de oxigênio 
de seis moléculas de água, formando um dipolo que exige grande quantidade de energia para ser removido, formando, assim, uma redoma no cátion que impede a ligação com o ânion de carbonato (WRIGHT, 1997; 2000). Barker e Kastner (1981), através de experimentos laboratoriais físico-químicos, concluíram que, apesar da água do mar ser supersaturada em dolomita, o mineral raramente se forma na presença de íons de sulfato dissolvido, mesmo em concentrações baixas, de até 5 vezes menores do que a da água do mar. Os autores relatam que a formação de dolomita só ocorreria em ambientes onde a concentração de sulfato dissolvido fosse muito baixa, a exemplo de sedimentos ricos em matéria orgânica, onde ocorrem processos de sulfato-redução, apontados pelos autores como forma de remover o sulfato da água e permitir a precipitação da dolomita. Este processo, segundo estes autores, explicaria provavelmente por que a ocorrência da dolomita é rara em sedimentos calcários puros, sem matéria orgânica.

Baker e Kastner (1981) discutem que a sulfato-redução promoveria a dolomitização devido a três aspectos: (a) por remoção dos íons de sulfato dissolvido, (b) devido ao aumento da alcalinidade e (c) por produzir $\mathrm{NH}_{4}{ }^{+}$que conseqüentemente libera íons de magnésio adsorvidos.

Para tentar explicar a gênese dos dolomitos, surgiram então numerosos modelos, baseados em substituição de calcários por fluidos ricos em magnésio em situações hidrogeológicas específicas (TUCKER; WRIGHT, 1990). Já em 1845, Haidinger considerava a possibilidade de substituição secundária de carbonato de cálcio por dolomita, justificando que a precipitação do mineral não era obtida em condições superficiais e apoiando em evidências de fósseis de amonites, originalmente calcíticos, que são encontrados em composição dolomítica (HAIDINGER, 1845 apud MCKENZIE; VASCONCELOS, 2009).

Nos últimos 40 a 50 anos, a descoberta da formação de dolomita em ambientes sedimentares modernos específicos, como nas sabkhas litorâneas em Abu Dhabi e lagoas hipersalinas no Brasil e na Austrália, abriu uma nova perspectiva para interpretação da gênese de dolomitos, que envolve a participação de microorganismos na precipitação do mineral dolomita (VASCONCELOS et al., 1995; VASCONCELOS; MCKENZIE, 1997; WRIGHT, 1997; WRIGHT; WACEY, 2005).

A hipótese da precipitação da dolomita relacionada à presença de microorganismos, no entanto, data do início do século XX. Segundo revisão sobre a evolução dos conhecimentos de McKenzie e Vasconcelos (2009), em 1928, o microbiologista russo Georgi A. Nadson (1867-1940) publicou, em uma revista acadêmica russa, a presença de finos grãos de dolomita precipitados em experimentos laboratoriais com culturas de bactérias sulfato-redutoras de um lago hipersalino. Já em 1928, o autor sugeriu que o entendimento dos fenômenos bacterianos poderia ser a solução para o "Problema Dolomito" 
(NADSON, 1928 apud MCKENZIE; VASCONCELOS, 2009). Seu trabalho não recebeu o devido reconhecimento na época, devido a pouca circulação da revista russa, o que o levou a publicá-lo em um periódico alemão de grande prestígio acadêmico, incluindo os comentários de Walther (1908) de que bactérias presentes nos poros dos sedimentos em ambientes marinhos seriam mediadoras para a precipitação do mineral dolomita (WALTHER, 1908 apud MCKENZIE; VASCONCELOS, 2009). No entanto, sua hipótese não deixou claro se as bactérias seriam responsáveis pela formação primária do mineral ou pela substituição do carbonato de cálcio pré-existente.

A hipótese de remoção do sulfato como fator indutor da precipitação primária de dolomita, por meio da ação de bactérias sulfato-redutoras presentes em níveis inferiores das esteiras microbianas (BAKER; KASTNER, 1981), encontrou grande impulso com a observação desse processo em ambiente moderno, na Lagoa Vermelha, Estado do Rio de Janeiro, por Vasconcelos et al. (1995). A degradação microbiana da matéria orgânica e particularmente a ação de bactérias sulfato-redutoras em níveis anóxicos, logo abaixo das superfícies de crescimento das cianobactérias, promoveriam as modificações bioquímicas necessárias para a formação de dolomita (VASCONCELOS et al., 1995; VASCONCELOS; MCKENZIE, 1997; VASCONCELOS et al., 2006).

No entanto, estudos recentes demonstraram que o mineral dolomita pode se formar mesmo na presença de íons de sulfato a partir de culturas de bactérias aeróbicas a temperaturas de $25^{\circ}$ a $35^{\circ} \mathrm{C}$ (SÁNCHEZ-ROMÁN et al., 2009). Nesses experimentos, observou-se que a quantidade de $\mathrm{SO}_{4}{ }^{2-}$ permanece inalterada antes e depois da precipitação da dolomita, indicando que o sulfato não é consumido. O estudo de SánchezRomán et al. (2009) contrasta com experimentos envolvendo bactérias anaeróbicas, nos quais foram observados a remoção da barreira cinética do sulfato durante o metabolismo de bactérias sulfato-redutoras, e precipitação da dolomita (WARTHMANN et al., 2000; VAN LITH et al., 2003; WRIGHT; WACEY, 2005).

Os autores defendem que a sulfato-redução, produzida por bactéria aneróbicas, pode induzir a precipitação de dolomita de forma semelhante ao que pode ocorrer com bactérias aeróbicas, o que sugere que os produtos do processo de sulfato-redução, como o aumento da alcalinidade, podem ser mais determinantes para a formação da dolomita do que simplesmente a remoção de sulfato. Em ambientes naturais atuais, onde há formação de dolomita, são observadas concentrações de íons de sulfato bem maiores do que as encontradas na água do mar, a exemplo das lagoas Vermelha e Brejo dos Espinhos, ambas localizadas no Rio de Janeiro (VAN LITH et al., 2002; VAN LITH et al., 2003; SÁNCHEZROMÁN et al., 2009). Desta forma, Sánchez-Román et al (2009) sugerem que o modelo do 
sulfato como inibidor da precipitação da dolomita não se aplica a muitos dos ambientes modernos onde ocorre a formação deste mineral.

A presença de bactérias pode induzir a precipitação da dolomita por dois fatores: (1) modificando as condições e/ou concentração de íons no envelope celular bacteriano e (2) servindo como sítios de nucleação, devido a adsorção de cátions ao redor da membrana celular ou da camada de polímero extra-celular (extracellular polymeric substances - EPS), que envolve as colônias bacterianas (SÁNCHEZ-ROMÁN et al., 2009).

Ainda estes autores descrevem que compostos orgânicos como aminoácidos, que

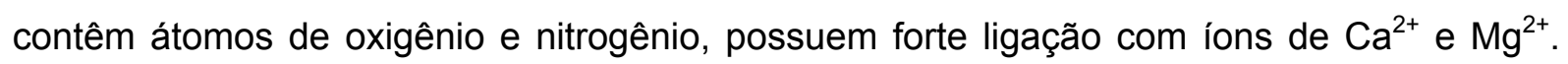
Durante a degradação destes compostos, por ação de bactérias aeróbicas, são liberados os íons de cálcio e magnésio juntamente com $\mathrm{CO}_{3}{ }^{2-}, \mathrm{HN}_{4}{ }^{+}$e $\mathrm{PO}_{4}{ }^{3+}$. A disponibilidade destes íons nas águas intersticiais e o aumento da alcalinidade devido à liberação de amônia permitem a precipitação de dolomita e também de minerais fosfáticos (SÁNCHEZ-ROMÁN et al., 2009).

Os experimentos de Baker e Kastner (1981) demonstraram claramente que o sulfato representaria um inibidor para a precipitação da dolomita, porém a temperaturas da ordem de $200^{\circ} \mathrm{C}$, enquanto Sánchez-Román et al. (2009) trabalharam a temperaturas ambiente $\left(25^{\circ}\right.$ a $\left.35^{\circ} \mathrm{C}\right)$. Desta forma, os resultados obtidos pelos segundos são aplicáveis a dolomitos primários formados em condições superficiais, enquanto o resultado dos primeiros é melhor aplicável a processos de dolomitização secundária em sedimentos soterrados, por substituição de calcários, a temperaturas de $200^{\circ} \mathrm{C}$.

No processo de sulfato-redução bacterial o oxigênio do íon $\mathrm{SO}_{4}{ }^{2-}$ dissolvido é utilizado no metabolismo das bactérias envolvidas, durante a decomposição da matéria orgânica. Este processo é dominante onde a taxa de sedimentação é relativamente baixa e quando a difusão da água do mar fornece $\mathrm{SO}_{4}{ }^{2-}$ suficiente para manter o processo (BURNS; BAKER, 1987; MAZZULLO, 2000). A metanogênese bacteriana, também relatada como um processo formador de dolomitas (BURNS; BAKER, 1987; MAZZULLO, 2000; SÁNCHEZROMÁN et al., 2009), predomina em áreas com elevada taxa de sedimentação e quando o $\mathrm{SO}_{4}$ não é mais fornecido por difusão, e é responsável pela fermentação dos carboidratos por remoção do oxigênio diretamente da matéria orgânica. A metanogênese e sulfatoredução não coexistem, já que a presença de sulfato inibe as reações de metanogênese. Normalmente a metanogênese substitui a sulfato-redução conforme a profundidade de soterramento e as taxas de sedimentação aumentam. Ambos os processos ocorrem em sedimentos ricos em matéria orgânica, sob condições anóxicas, desde ambientes de supramaré até em águas marinhas profundas. Mazzullo (2000) considera que os dois processos levariam a superação de barreiras químicas para a formação da dolomita, 
permitindo a precipitação do mineral e demonstra a complexidade do processo de formação da dolomita e que sua gênese primária pode ser explicada a partir de mais de um processo geoquímico.

Os estudos na Lagoa Vermelha demonstram dois mecanismos diferentes para a formação de carbonato, operantes em diferentes níveis de profundidade em esteiras microbianas (VASCONCELOS et al., 1995; VASCONCELOS; MCKENZIE, 1997; VAN LITH et al., 2002; MOREIRA et al., 2004).

As esteiras microbianas possuem em média $3 \mathrm{~cm}$ de espessura e são compostas por lâminas de carbonato alternados com lâminas orgânicas não litificados assemelhando-se a estrutura estromatolítica. As porções de precipitação de carbonato são embebidas em matriz de EPS e microorganismos. A composição microbiana das esteiras da Lagoa Vermelha (Figura 6.1) registra, no topo, porção verde com bactérias fotossintetizantes, seguidos de porções de cor marrom constituídas por bactérias heterótrofas, porções vermelhas com bactérias roxas de enxofre e uma última porção cinza, com bactérias sulfato-redutoras (VASCONCELOS et al., 2006).

Os referidos autores concluíram que os processos metabólicos microbianos, acompanhados das mudanças de alcalinidade, são responsáveis pela precipitação de carbonato nas esteiras microbianas da Lagoa Vermelha. Fotossíntese oxigenada e respiração aeróbica resultam em precipitação de calcita nos níveis superiores da esteira e os processos diagenéticos de sulfeto-oxidação aliada a sulfato-redução promovem a precipitação de calcita magnesiana e cálcio dolomita, nos níveis inferiores da esteira microbiana.

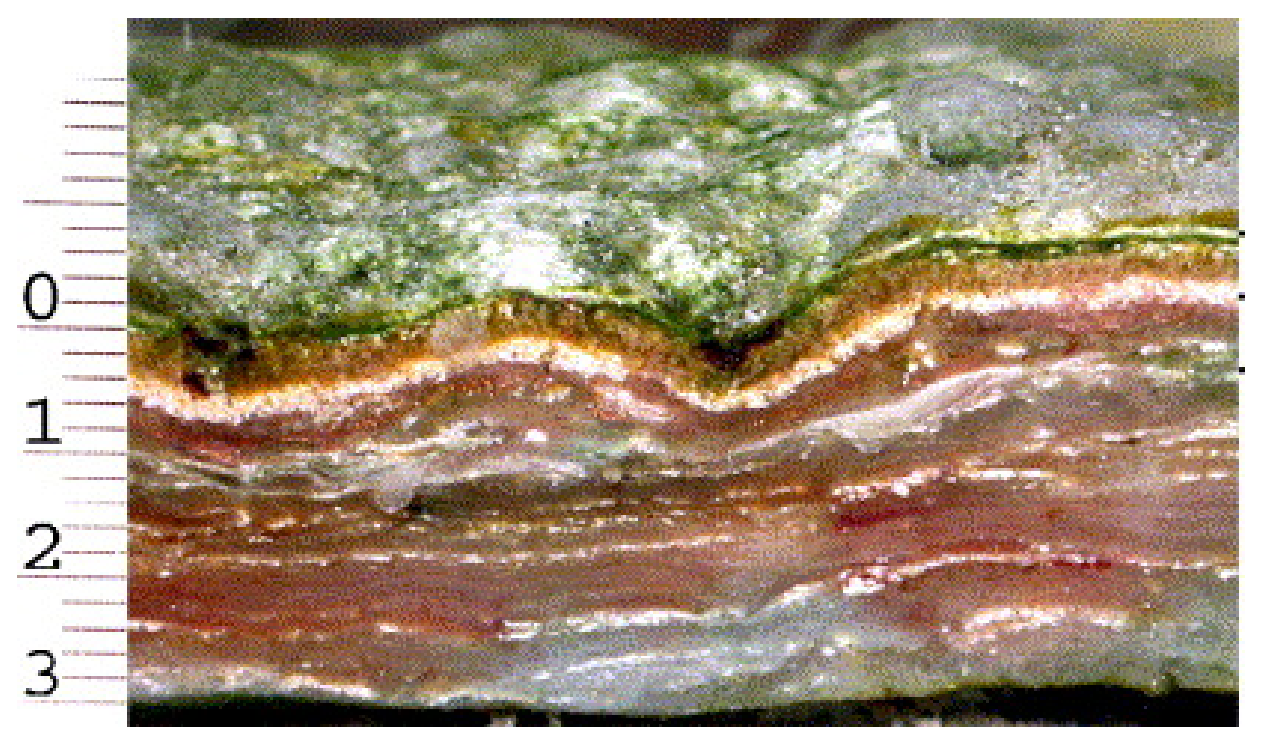

Figura 6.1 - Corte transversal de esteira microbiana da Lagoa Vermelha (RJ). É possível observar a alternância de lâminas com precipitação de carbonato (cores brancas) e lâminas orgânicas nãolitificadas (verde). Escala, a esquerda, em centímetros (VASCONCELOS et al., 2006). 
As observações na região de Coorong, no sul da Austrália (WRIGHT, 1997; 2000; WRIGHT; WACEY, 2005), evidenciam aumento da concentração de magnésio e da alcalinidade devido à intensa sulfato-redução por degradação das colônias de cianobactérias. A quebra enzimática das proteínas, na decomposição da matéria orgânica, liberaria amônia o que promoveria a elevação do $\mathrm{pH}$ e da alcalinidade a níveis esperados para precipitação de dolomita (WRIGHT, 1997). O processo bioquímico ocorreria logo abaixo da interface com a contínua modificação bioquímica da água intersticial. Em análise, pelo referido autor, de Conophyton arqueanos da África do Sul, constatou a presença e aumento de cristais de dolomita autigênica em matriz calcítica acompanhada do progressivo aumento da desintegração de bainhas de cianobactérias. As bainhas das cianobactérias são naturalmente enriquecidas em magnésio e mais resistentes a degradação que o resto da célula, permanecendo por mais tempo preservadas. Durante a degradação das esteiras microbianas, o magnésio concentrado nas bainhas orgânicas das cianobactérias seria liberado, enriquecendo a água em níveis até três vezes superiores aos da água do mar (GEBELEIN; HOFFMAN, 1973; WRIGHT, 1997; 2000).

Em porções de total degradação das bainhas, Wright (2000) descreve a ocorrência de doloesparito sem nenhuma evidência da origem microbiana. Relação semelhante foi também observada em amostras de silicificação diagenética precoce de sedimentos microbianos da Formação Eilean Dubh (NW da Escócia), onde a dolomitização foi interpretada como ocorrido nos estágios iniciais da diagênese.

O estudo desses ambientes modernos demonstra a importância dos processos microbianos na formação de carbonatos, com a presença de células ativas associadas a biofilmes. Os experimentos com culturas sugerem que é necessário a presença microbiana para a precipitação de dolomita, que permitem criar condições favoráveis para a formação da dolomita (VASCONCELOS; MCKENZIE, 1997; WARTHMANN et al., 2000; VAN LITH et al., 2003; WRIGHT; WACEY, 2005; BONTOGNALI et al., 2010).

Do ponto de vista evolucionário, as bactérias sulfato-redutoras são um dos organismos mais antigos conhecidos, e juntamente com as cianobactérias, provavelmente, dominaram os ecossistemas do Pré-Cambriano, uma vez que não havia competição por alimento ou espaço. Sob a ótica dos modelos microbianos para formação de dolomitas, a explicação para abundância de dolomitos no Pré-Cambriano, e relativa ausência no Fanerozóico, seria em função da presença relativamente maior de comunidades microbianas, representadas por estromatólitos, no passado e o declínio dessas no início do Fanerozóico, com surgimento de organismos superiores, como vertebrados e crustáceos, predadores das comunidades bentônicas. Esta associação também explicaria a maior abundância relativa de dolomitos em relação aos calcários calcíticos no Pré-Cambriano, 
onde os dolomitos representariam fácies sedimentares de águas rasas (supra e intermarés) e os calcários, fácies de águas relativamente mais profundas. Os ambientes modernos, onde se registra a formação de dolomita, podem representar análogos para os ecossistemas do passado da Terra e o modelo microbiano para a formação da dolomita é apontado, atualmente, como uma possível solução para o "Problema Dolomito".

Em estudos referentes à gênese de dolomitos microbianos no Pré-Cambriano, Corsetti et al. (2006) discutem que a dolomitização das seqüências neoproterozóicas do Death Valley (Califórnia) ocorreu em diagênese precoce, bem próxima a superfície, preservando as estruturas sedimentares primárias da calcita ou aragonita, como os oóides e textura do cimento, no que os autores denominaram como "dolomitos miméticos". A baixa concentração de sulfato nos oceanos do Neoproterozóico, uma vez que esta concentração é proporcional ao conteúdo de oxigênio na atmosfera, considerada baixa para o período, aliada a elevada razão Mg/Ca são as prováveis causas, apontadas pelos referidos autores, para a dolomitização em larga escala na sucessão do Death Valley (CORSETTI et al., 2006).

Entretanto, a partir do início do Cambriano, não se observa mais a presença de grandes quantidades de dolomitos miméticos. Segundo Corsetti et al. (2006), mudanças significativas ocorreram no campo da diagênese precoce durante a transição PréCambriano/Cambriano, relacionadas com o aparecimento da bioturbação penetrativa, apontada como responsável pela oxigenação dos sedimentos, promovendo desequilíbrio no delicado ecossistema das esteiras microbianas, reduzindo drasticamente sua presença nos ambientes sedimentares.

A hipótese de Corsetti et al. (2006) é de que as condições para formação de dolomitos miméticos estão intimamente relacionada com a presença de sedimentos capeados por esteiras microbianas durante o Pré-Cambriano. Assim, a dolomitização mimética, volumetricamente importante, teve fim com o advento da bioturbação penetrativa (a partir do Cambriano) e nunca mais retornou a estas quantidades durante o resto do tempo geológico. 


\section{PETROGRAFIA DAS ROCHAS DA FORMAÇÃO BOCAINA}

A Formação Bocaina é composta por dolomitos com abundantes estruturas estromatolíticas, diversidade de grãos revestidos, brechas intraformacionais e níveis de fosforito, marcada por grande variação lateral e vertical de fácies sedimentares.

Para a individualização destas fácies, foram realizadas descrições de campo complementadas por descrições petrográficas de amostras coletadas por toda a área de exposição da formação, desde as proximidades do município de Bonito até Corumbá, concentrando-se principalmente na Fazenda Ressaca e no Morro do Bugio (Figura 3.1.1), onde foram levantadas seções estratigráficas, além do clássico afloramento de Porto Morrinhos.

\subsection{Fácies Sedimentares da Fazenda Ressaca}

A Fazenda Ressaca, principal localidade estudada no presente trabalho, corresponde a uma elevação topográfica suave, com inclinação de $10^{\circ}$. Neste local, foi realizado um perfil de caminhamento com cerca de $435 \mathrm{~m}$ de comprimento na direção NESW, cujas camadas mergulham com ângulos de por volta $35^{\circ}$ para SE, o que possibilitou a construção de uma seção colunar e coleta de amostras.

A seção colunar (Figura 7.1.1) possui espessura superior a $200 \mathrm{~m}$, na qual foram coletadas amostras representativas de cada fácies sedimentar totalizando 25 amostras, indicadas na figura 7.1.1 com o código FR, seguido de números ordinais. A sucessão encontra-se em posição normal, certificada pela orientação das laminações estromatolíticas. Posteriormente, foram coletadas outras seis amostras, identificadas com o código 09-BOC (referente ao ano de coleta do material e à sigla adotada para a Formação Bocaina) que foram posicionadas também na seção estratigráfica.

Com base nas observações de campo e também ao microscópio petrográfico, foi possível refinar a descrição das micro-fácies, que exibem boa preservação das estruturas sedimentares primárias. São encontradas predominantemente fácies de grainstones oolíticos, pisolíticos, mudstones e boundstones. 


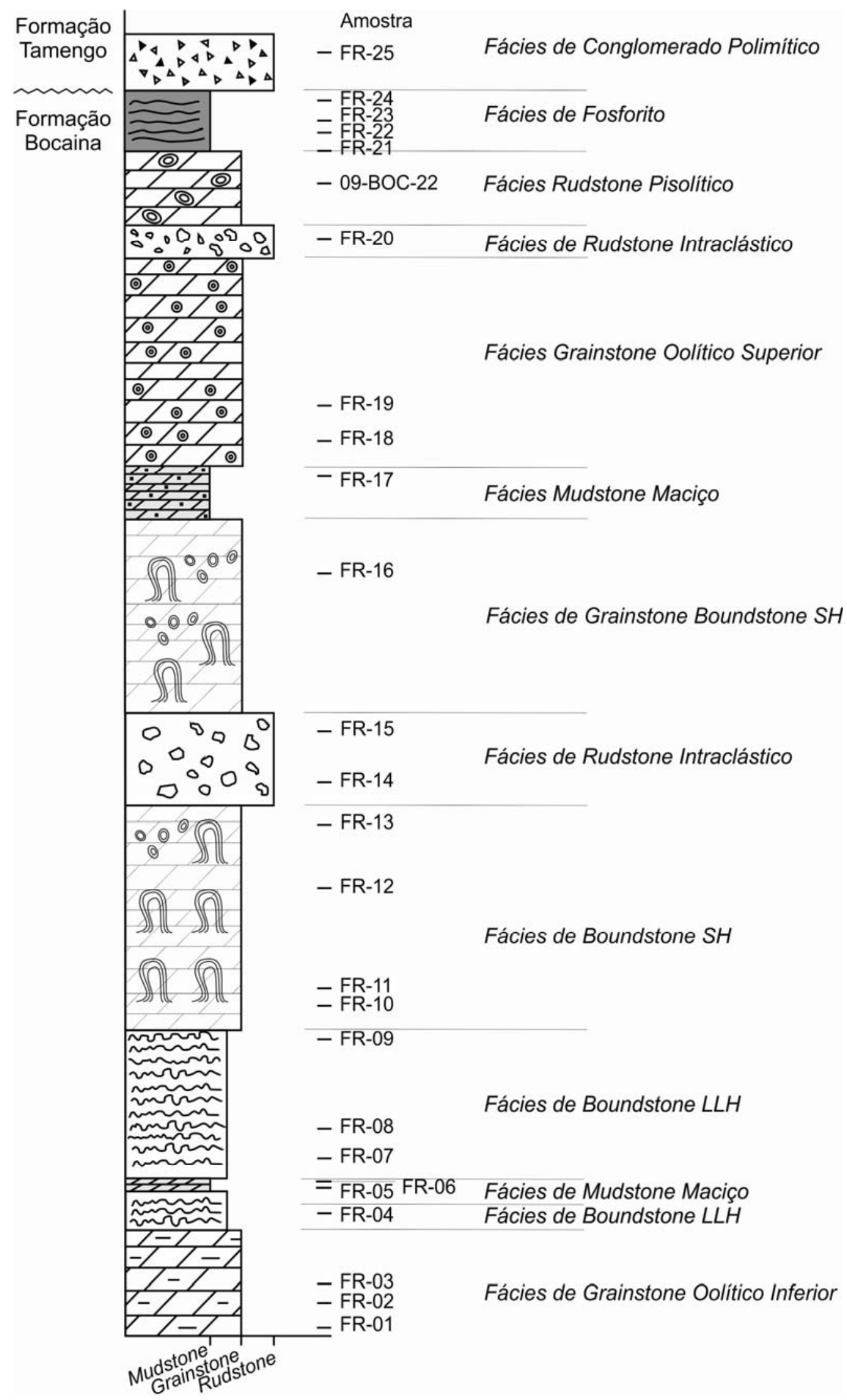

Figura 7.1.1 - Coluna estratigráfica do topo da Formação Bocaina e base da Formação Tamengo na Fazenda Ressaca, município de Bonito, MS. 


\subsubsection{Fácies de Grainstone Oolítico Inferior}

Amostras: FR-01, 02, 03

Descrição: Dolomitos oolíticos, cujos oóides, em parte das amostras, não se encontram preservados, sendo identificados apenas pela borda micritizada, na qual se observa, por vezes, cristais romboédricos de dolomita espática de até $100 \mu \mathrm{m}$ de comprimento e núcleo recristalizado do oóide (Figura 7.1.2). Os núcleos dos oóides, eventualmente, estão preenchidos por quartzo (Figuras 7.1 .2 e 7.1.3), cujos cristais variam de 0,05 a $1 \mathrm{~mm}$ de comprimento, anédricos, com contatos lobados a interdigitados entre si e extinção ondulante, além do preenchimento por dolomita espática. Entre os oóides, encontra-se cimento dolomítico espático (Figura 7.1.3).
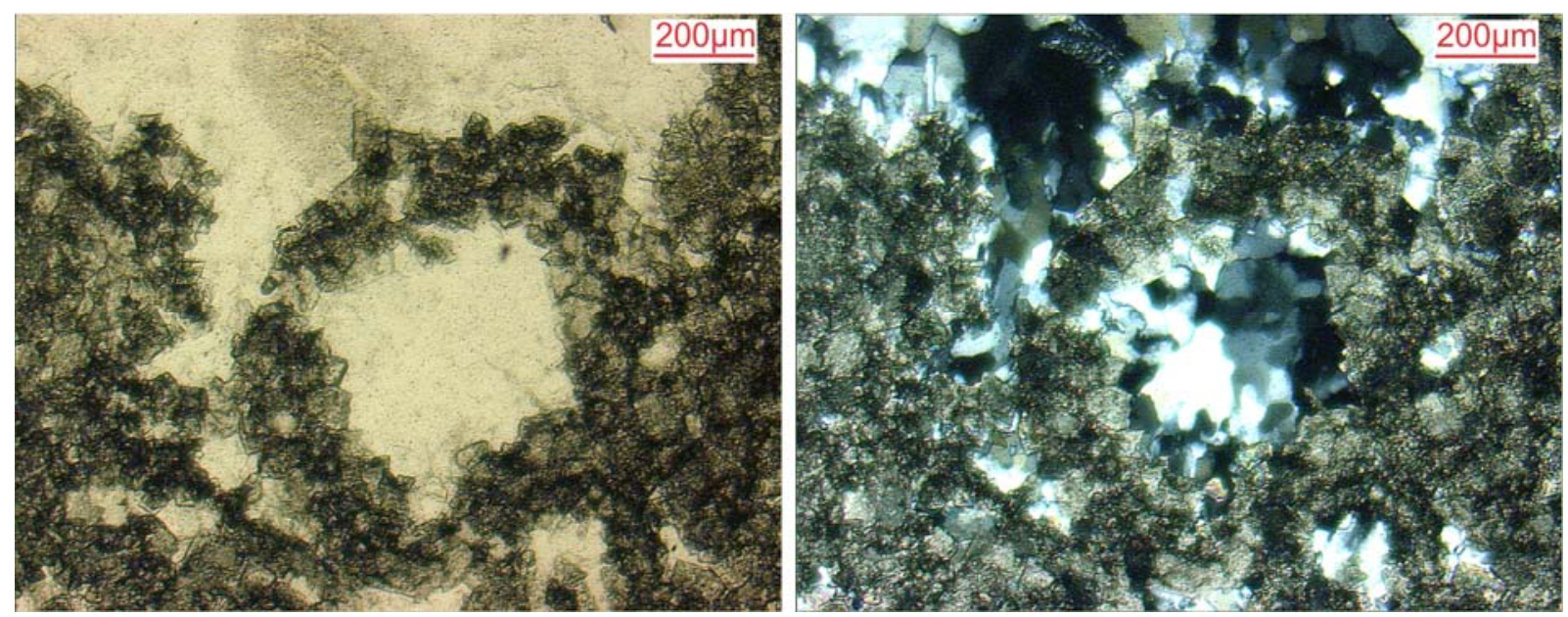

Figura 7.1.2 - Romboedros de dolomita delimitando a borda dos oóides. À direita, observar que o núcleo do oóide está preenchido por quartzo. Nicóis paralelos (à esquerda) e nicóis cruzados (à direita).
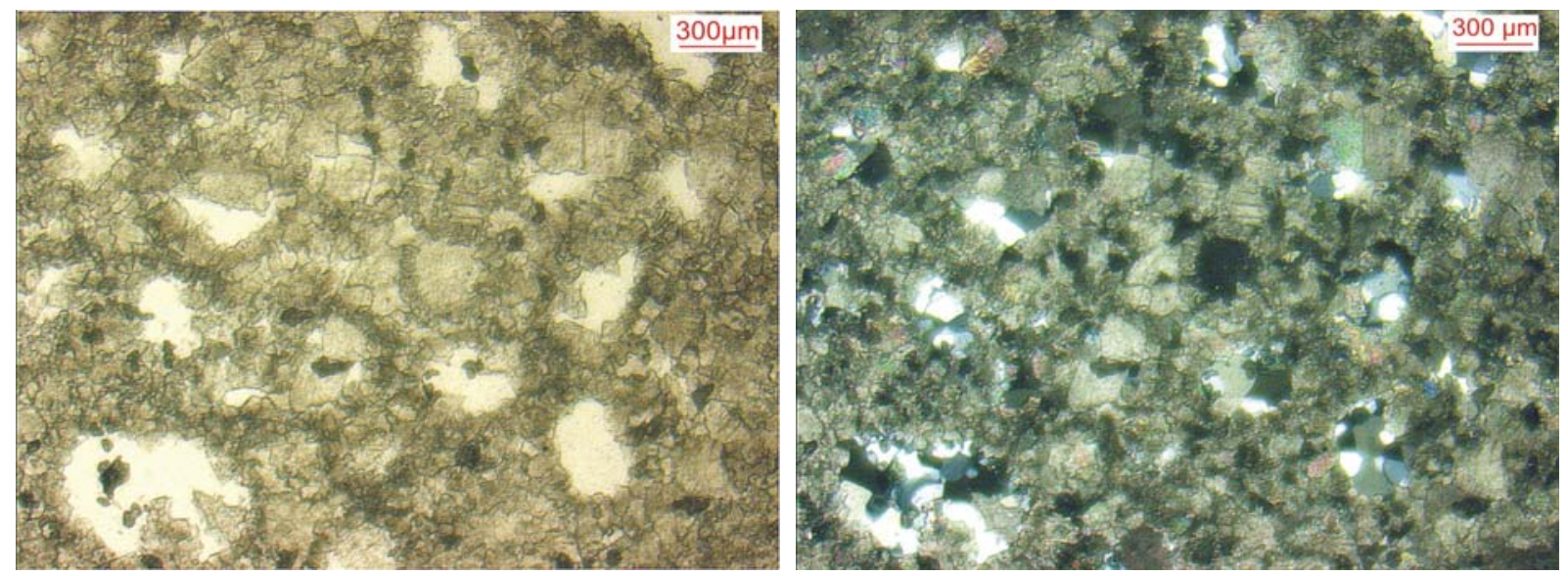

Figura 7.1.3 - Núcleo de oóides preenchidos com quartzo e carbonato. Observa-se cimento dolomítico também entre os grãos oolíticos. Nicóis paralelos (à esquerda) e nicóis cruzados (à direita). 
Interpretação: Oóides são descritos na literatura como grãos revestidos, de diâmetro inferior a $2 \mathrm{~mm}$, caracterizados por laminação concêntrica uniforme ao redor de um núcleo, que pode ou não estar presente. São característicos de ambientes de águas rasas e agitadas, cujas profundidades são, em geral, inferiores a $5 \mathrm{~m}$, mas podem ocorrer a profundidades de 10 a $15 \mathrm{~m}$. São encontrados nos mais diversos ambientes, desde marinhos, em fácies de inter e inframarés, sujeitos a correntes de marés e tempestade, como nas Bahamas, a ambientes lacustrinos, como em Great Salt Lake, hipersalinos ou não, e até fontes termais, como encontrado na Turquia (PERYT, 1983; TUCKER, 2001). Atualmente, são encontrados em regiões de águas quentes, a baixas latitudes, como a exemplo das Bahamas, Golfo de Suez, Golfo Persa e Plataforma de Yucatã (PERYT, 1983).

Oóides modernos exibem cristais de calcita ou aragonita fibrorradiados, no entanto, oóides pré-cambrianos e paleozóicos não apresentam esta orientação dos cristais preservada. A conversão de aragonita para calcita durante a diagênese pode implicar na dissolução parcial ou completa dos grãos, restando apenas os "oomoldes", que podem ser preenchidos por cimento calcíticos posteriormente. Muitos oóides antigos apresentam lâminas micritizadas, processo atribuído à presença de microorganismos endolíticos que degradam o carbonato de cálcio (TUCKER, 2001).

A origem dos oóides é atribuída a processos inorgânicos, nos quais águas supersaturadas em $\mathrm{CaCO}_{3}$, com a agitação do ambiente, liberam $\mathrm{CO}_{2}$ (degassing) e somadas à elevada temperatura, permitem a precipitação de carbonato de cálcio ao redor de um núcleo. A origem biogeoquímica não é descartada, mas sua contribuição é diminuta na formação de oóides, mas expressiva na formação de oncóides.

Os oóides da fácies de Grainstone oolítico inferior constituem "oomoldes", cujas bordas dos grãos estão preservadas por cristais espáticos de dolomita (Figura 7.1.2) e também pela micritização (Figuras 7.1.2 e 7.1.3). O processo de geração de porosidade está diretamente ligado à dissolução, que provavelmente ocorreu na diagênese precose, já que os poros preservam a forma dos oóides sem indícios de compactação. O preenchimento dos poros por cimento carbonático e silicoso também deve ter ocorrido precocemente, já que preservaram os "oomoldes". A micritização das lâminas carbonáticas pode ser atribuída à ação de bactérias endolíticas na diagênese.

Para a origem da composição dolomítica desta fácies, há duas possibilidades: (1) a composição original dos oóides era aragonita ou calcita que foi substituída por dolomita ainda na eodiagênese, possivelmente devido a elevada taxa de evaporação e refluxo de águas oceânicas ou (2) os oóides são constituídos originalmente de dolomita. Considera-se mais provável a primeira possibilidade, já que não há descrito na literatura dolomita primária formada em ambientes de elevada energia, como esperado para a formação de oóides. 


\subsubsection{Fácies de Boundstone LLH}

Amostras: FR-04, 05, 06, 07, 08 e 09

Descrição: Dolomito fino cinza claro, estromatolítico com laminação ligada lateralmente, predominantemente plano-paralela irregular e, subordinadamente, pseudo-colunares (Figura 7.1.4). Em seção delgada, a rocha apresenta-se totalmente recristalizada, porém é possível identificar a laminação estromatolítica, crenulada e em forma bulbosa constituída de dolomita fina, por vezes destacada por um filme de cor preta, e fenestras com diâmetro superiores a $4 \mathrm{~mm}$, preenchida por cimento dolomítico espático, alternada à lâminas lâminas silicificadas (Figura 7.1.5). Estas lâminas possuem aproximadamente 0,6 mm de espessura, nas quais o quartzo possui textura sacaroidal e extinção ondulante (Figura 7.1.5). Associadas com os estromatólitos, são encontrados também grãos arredondados, ovais ou de formas irregulares de até $1 \mathrm{~mm}$ de diâmetro, constituídos possivelmente de micrita ou matéria orgânica (Figura 7.1.6).

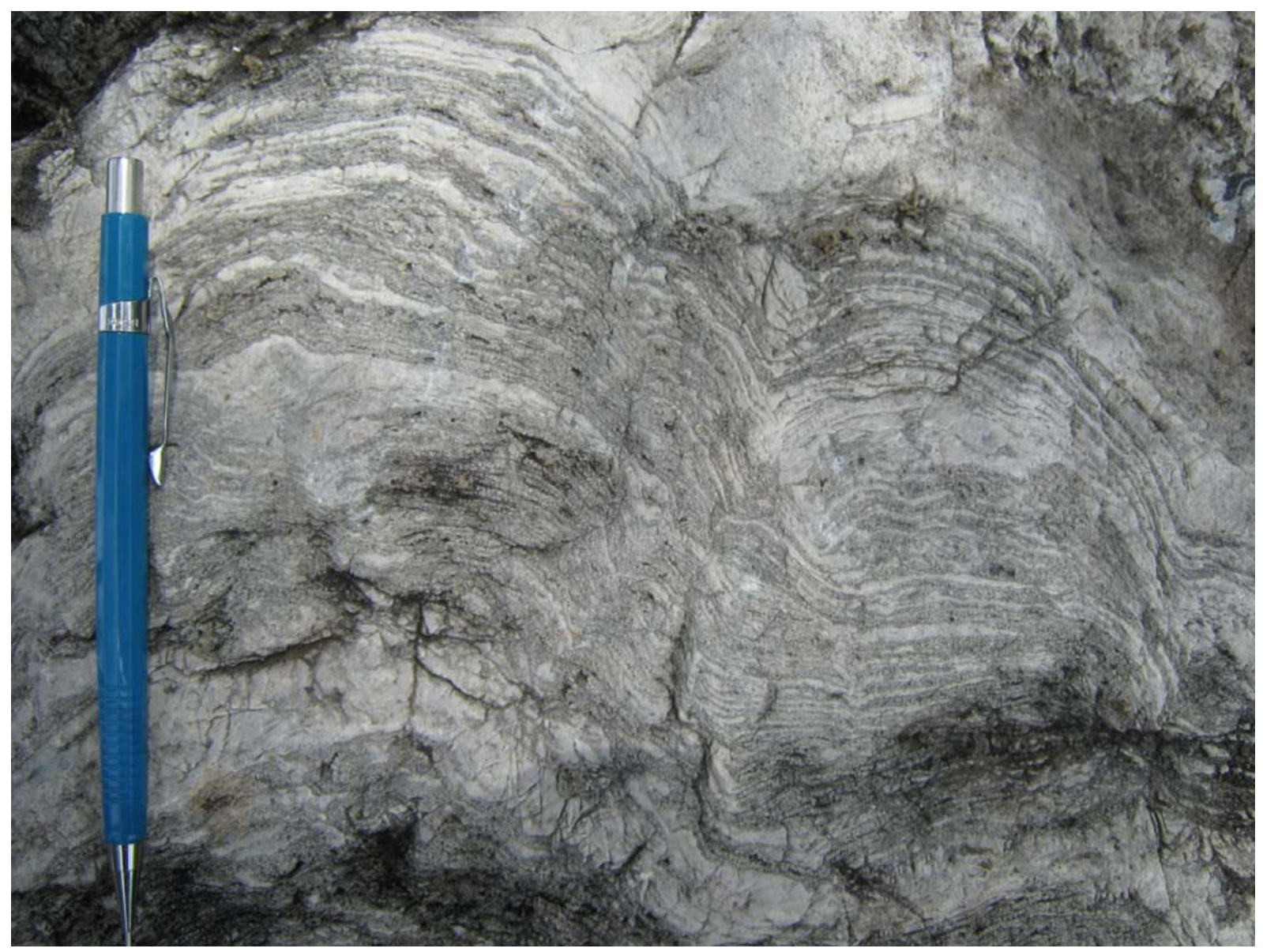

Figura 7.1.4 - Estromatólito com laminação pseudo-colunar. 

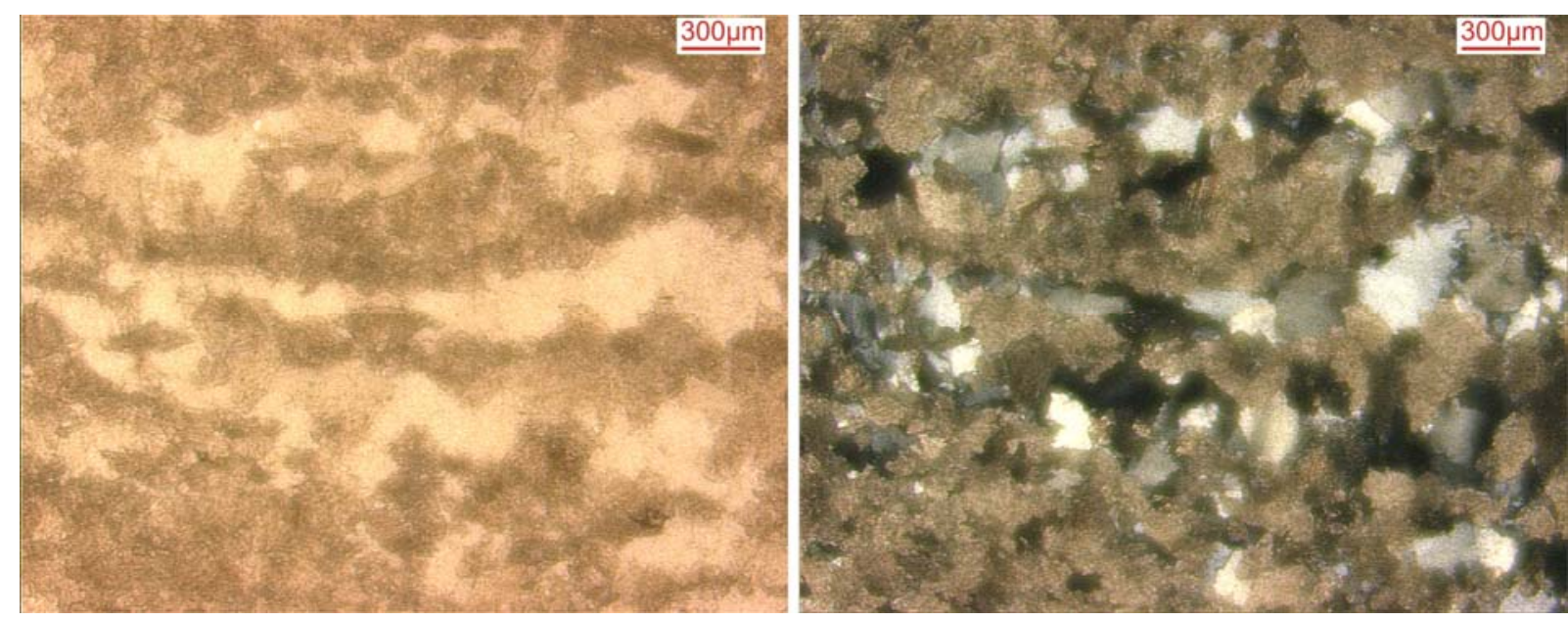

Figura 7.1.5 - Laminação estromatolítica vista ao microscópio petrográfico. Observar a alternância de lâminas de dolomita e quartzo. Nicóis paralelos, à esquerda e nicóis cruzados, à direita.
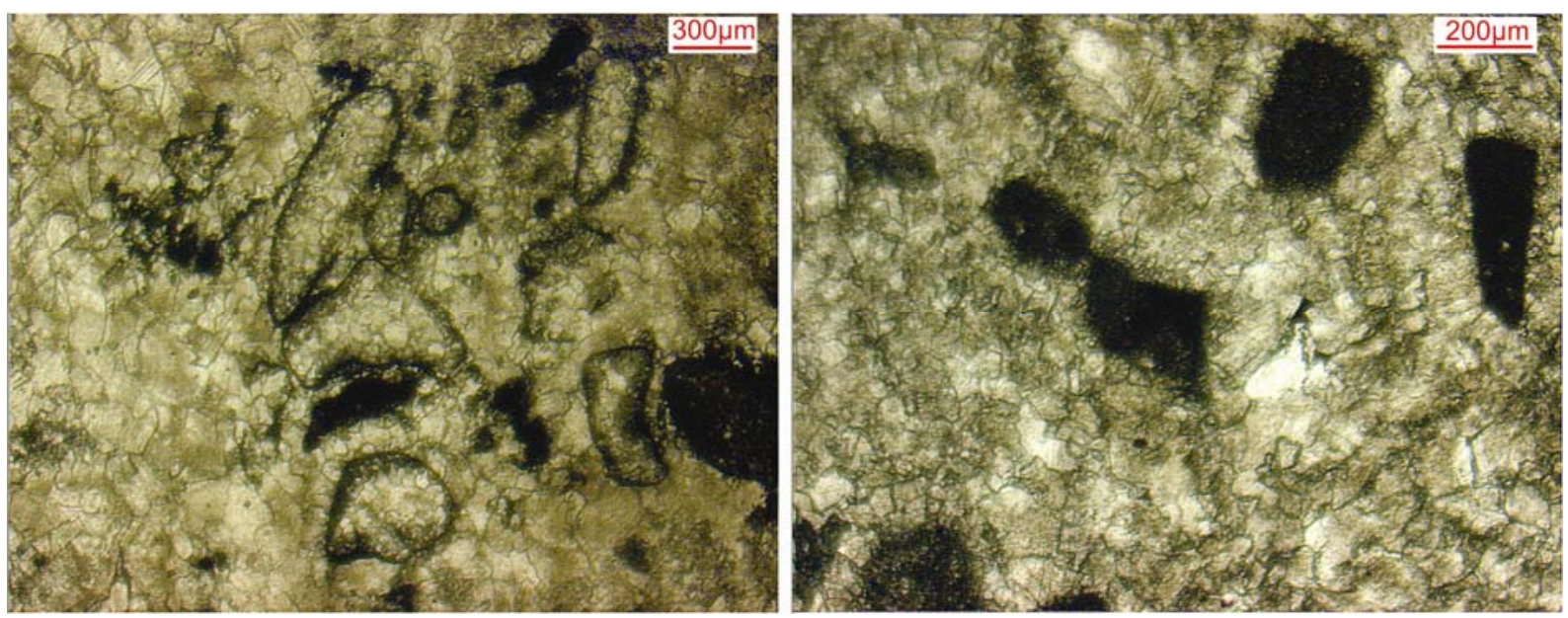

Figura 7.1.6 - Partículas arredondadas, ovais e irregulares identificadas pelo envoltório preto, constituídas possivelmente de micrita ou matéria orgânica.

Interpretação: Historicamente, estromatólitos são definidos como estruturas organossedimentares produzidas pelo aprisionamento de partículas sedimentares na mucilagem microbiana e/ou precipitação de carbonato de cálcio como resultado do crescimento e atividade metabólica de microorganismos, especialmente cianobactérias (WALTER, 1976). São considerados o registro fóssil mais antigo de vida no planeta, e sua ocorrência é datada de antes de $3,5 \mathrm{Ga}$ (SCHOPF, 1983). No entanto, alguns autores dissociam o conceito de estromatólito à presença de microorganismos, considerando apenas a estrutura sedimentar, que poderia ser gerada abioticamente (SEMIKHATOV et al., 1979; GROTZINGER; ROTHMAN, 1996).

Os estromatólitos modernos são registrados em ambientes marinhos e não marinhos, desde supramarés até profundidades moderadas de inframarés, em latitudes baixas à médias. Atualmente, os estromatólitos são encontrados, em geral, em ambientes 
hipersalinos, como o caso dos clássicos exemplos de Shark Bay, na Austrália e nas sabkhas do Golfo Arábico, especialmente devido à ausência de predadores para as comunidades bentônicas, porém acredita-se que no Pré-Cambriano, eles tenham ocupado os mais diversos nichos ecológicos justamente pela ausência de predadores (CORSETTI et al., 2006; VASCONCELOS et al., 2006).

Quanto à morfologia dos estromatólitos, há uma grande variedade de formas, desde planas (esteiras ou tapetes microbianos), colunares $(\mathrm{SH})$, dômicas (ligadas lateralmente LLH) até esferoides (oncóides - SS), que variam basicamente com a energia do meio (ondas e marés), taxa de sedimentação, profundidade da lâmina d'água e freqüência de exposição subaérea (LOGAN et al., 1964; TUCKER, 2001).

Os oncóides são grãos revestidos formados pela ação de microorganismos. São encontrados em ambientes marinhos, nas zonas de intermarés até inframarés raso, lacustres e fluviais, em zona freática. Diferem-se dos oóides por possuírem laminação crenulada e dimensões variadas. Estão presentes tanto em ambientes de águas agitadas, como também em águas calmas, com matriz micrítica ou cimento espático (PERYT, 1983).

As partículas arredondadas de coloração preta são descritas na literatura como microfitólitos. Swett e Knoll (1985) descrevem microfitólitos como uma variedade de grãos (oóides, oncólitos, grapestone, intraclastos, etc) derivados do crescimento de bactérias ou cianobactérias, associados com processos de mineralização inorgânica, abrasões periódicas, eventos erosivos e processos neomórficos. Nobre \& Coimbra (2000) descrevem microfitólitos no Grupo Bambuí, como "pequenas vesículas subesféricas, ovais ou irregulares que podem ainda formar agregados (...) limitados por um envelope micrítico, escuro". Os autores consideram o processo de formação destes grãos semelhante ao descrito por Swett \& Knoll (1985), incluindo processos orgânicos e inorgânicos não correspondendo portanto a um tipo fóssil definido (NOBRE; COIMBRA, 2000). Para Swett \& Knoll (1985) foram interpretados como indicadores de paleoambiente, sugerindo condições de correntes de energia baixa à intermediária, devido ao não paralelismo das lâminas internas e as poucas evidências de abrasão, e intermediária a alta energia devido à presença de grãos oolíticos e estratificação cruzada, nos litotipos estudados (SWETT; KNOLL, 1985).

Para a fácies de Boundstone LLH, a presença de estromatólitos pseudo-colunares variando para esteiras microbianas e oncólitos, indica ambiente de águas rasas, límpidas e oxigenadas, com nível moderado de energia. Os possíveis microfitólitos indicariam também ambiente rico em matéria orgânica. No entanto, para a confirmação se são formados de matéria orgânica preservada ou apenas micrita seria necessário fazer análise de carbono orgânico total (COT) das amostras. 
Nestas amostras, observa-se que a dolomita apresenta-se como cristais euédricos, de aproximadamente $100 \mu \mathrm{m}$ de comprimento, aparentemente recristalizando os microfitólitos e as laminações estromatolíticas. Desta forma, interpreta-se que esta dolomita é diagenética tardia, possivelmente formada na mesodiagênese.

A sílica encontrada nas lâminas estromatolíticas possui textura sacaroidal e extinção ondulante, o que sugere que é também tardia. Possivelmente a alternância entre lâminas dolomíticas e silicosas reflita heterogeneidade sedimentar (mineralogia, diferença na quantidade de matéria orgânica) ou que uma fase esteja substituindo a outra, o que não foi possível estabelecer apenas com análise ao microscópio petrográfico.

\subsubsection{Fácies de Mudstone maciço}

\section{Amostras: FR-06B e FR-17}

Descrição: Camadas pouco espessas de mudstone maciço, por volta de 1 a $2 \mathrm{~m}$, ou a níveis centimétricos intercalados às fácies de grainstone oolítico. Em seção delgada, os mudstones apresentam-se homogêneos e com textura micrítica, sem sinais de recristalização e, aparentemente, maciços.

Análise de difração de raios- $x$ demonstra que a amostra é composta praticamente de dolomita, além de quartzo e calcita subordinados (Anexo A - Figura 1).

Interpretação: mudstones estão presentes em diversos ambientes sedimentares, desde sedimentos de águas profundas, até sedimentos lacustres. Caracterizam, em geral, ambientes de baixa energia. Outra possibilidade para a formação de mudstones, descrita na literatura, é a da obliteração das estruturas sedimentares primárias devido à ação de microorganismos na degradação das bainhas de cianobactérias, durante a eodiagênese, por processos de organogênse (WRIGHT, 1997).

Para a fácies de mudstone da Fazenda Ressaca interpreta-se ambiente de águas calmas, possivelmente rasas e protegidas da ação de ondas e correntes (DAVIS, 1983), como em uma laguna, considerando o contexto na qual ocorrem, em conjunto com estromatólitos. Não se descarta a possibilidade organogenética. 


\subsubsection{Fácies de Boundstones SH}

Amostras: FR-10, 11, 12, 13 e 16

Descrição: Dolomitos cinza-escuros com presença de estromatólitos colunares a pseudocolunares (tipo $\mathrm{SH}$ ) centimétricos a métricos, associados ou não com oncólitos (Figura 7.1.7). É recorrente em vários níveis da seção, sendo que próximo ao topo apresenta oncólitos de diâmetros de até $6 \mathrm{~cm}$. Na base desta fácies predominam oóides arredondados a ovalados, de 0,4 a $1 \mathrm{~mm}$ de diâmetro maior, comumente com parcial silicificação das estruturas oolíticas (Figura 7.1.8).

A difração de raios-x da amostra FR-10 confirmou a composição dolomítica, apontada no pico principal, em vermelho (Anexo A - Figura 1). O quartzo também aparece na difração raios-x, confirmando as observações petrográficas. Subordinadamente observase a presença de calcita.
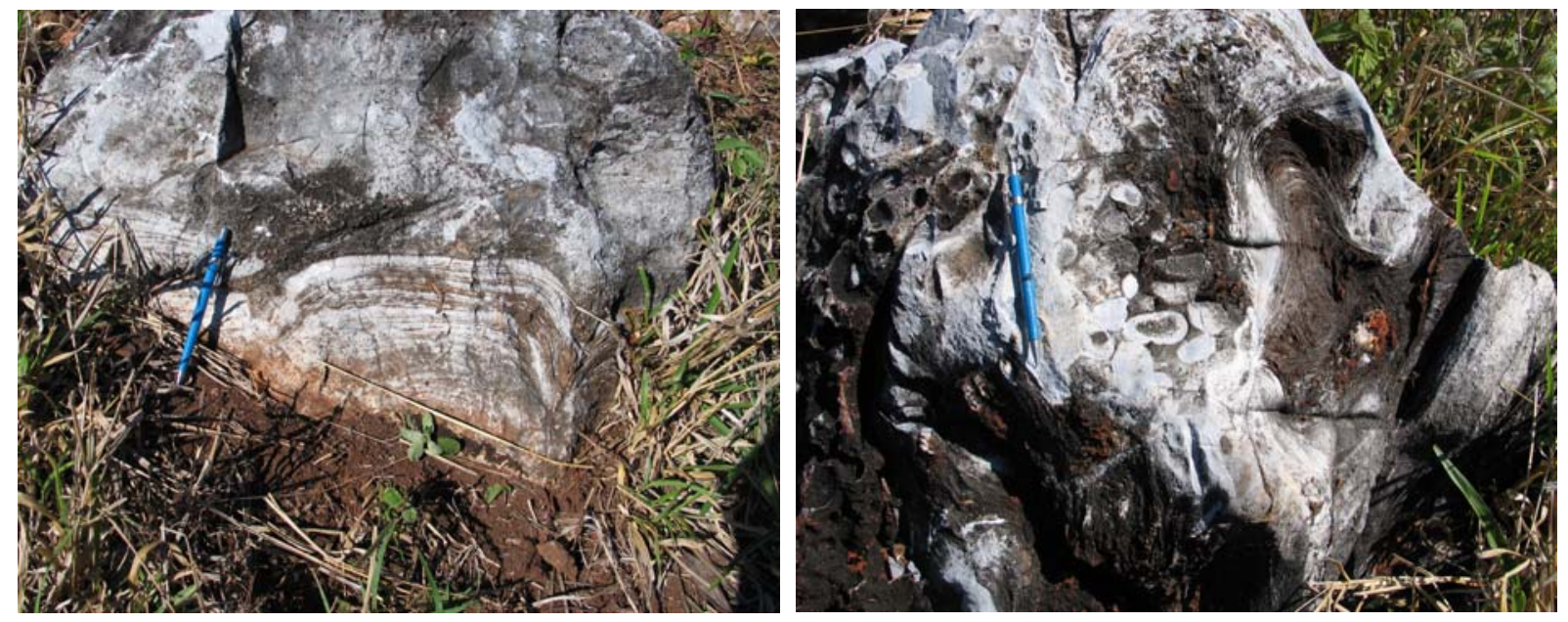

Figura 7.1.7 - Estromatólitos pseudo-colunares e oncólitos.
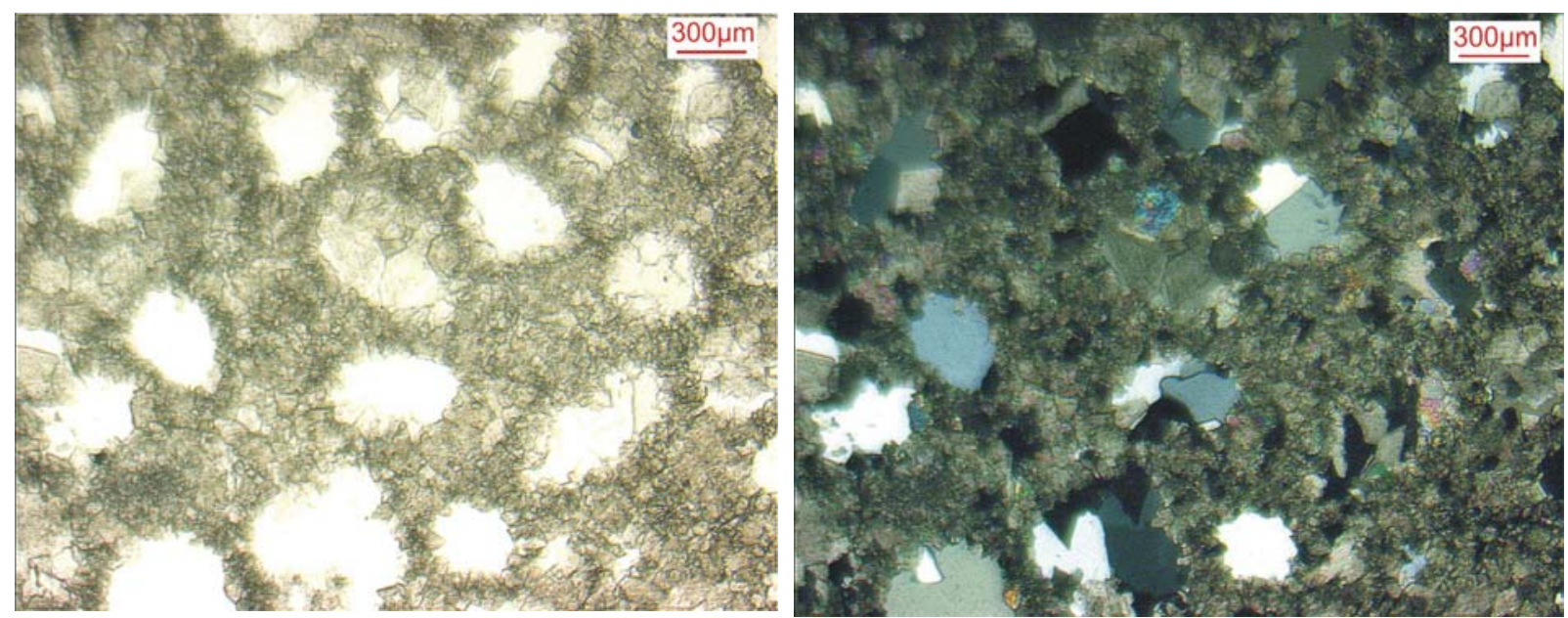

Figura 7.1.8 - Estruturas circulares interpretadas como oóides. Nicóis paralelos (à esquerda) e nicóis cruzados (à direita). Notar a substituição de carbonato por quartzo no núcleo dos oóides. 
Interpretação: a presença de estromatólitos colunares a pseudo-colunares e oóides leva a interpretação de ambiente de águas agitadas, límpidas e rasas (LOGAN et al., 1964; TUCKER, 2001).

Como os oóides presentes estão dissolvidos, interpreta-se que ocorreu processo semelhante descrito anteriormente para a fácies de Grainstone oolítico inferior.

\subsubsection{Fácies de Grainstone Oolítico Superior}

Amostras: FR-18 e 19.

Descrição: Pacotes espessos ( 20 m) de grainstone dolomítico cinza-escuro, recorrente na coluna estratigráfica da Fazenda Ressaca, (Figura 7.1.9) com estratificação plano-paralela e cruzada (Figura 7.1.9). Em seção delgada, é possível observar a predominância de oóides, cujas formas são em geral regulares, elipsoidais, com tamanho variando entre 0,4 e 1,0 mm no maior diâmetro, ocorrendo também, mas em menor freqüência, oóides de maior dimensão (macro-oóide ou psóide) (Figura 7.1.10). A presença de intraclastos é também freqüente, inclusive como núcleo do grão revestido (Figura 7.1.10). Textura grapestone é observada localmente, tratando-se de oóides reenvelopados. Em oóides bem preservados, observam-se lâminas envoltórias micritizadas ou constituídas de matéria orgânica.

A composição das amostras é dolomítica, confirmada pela difração de raios-x (Anexo A - Figura 1), em textura xenotópica.
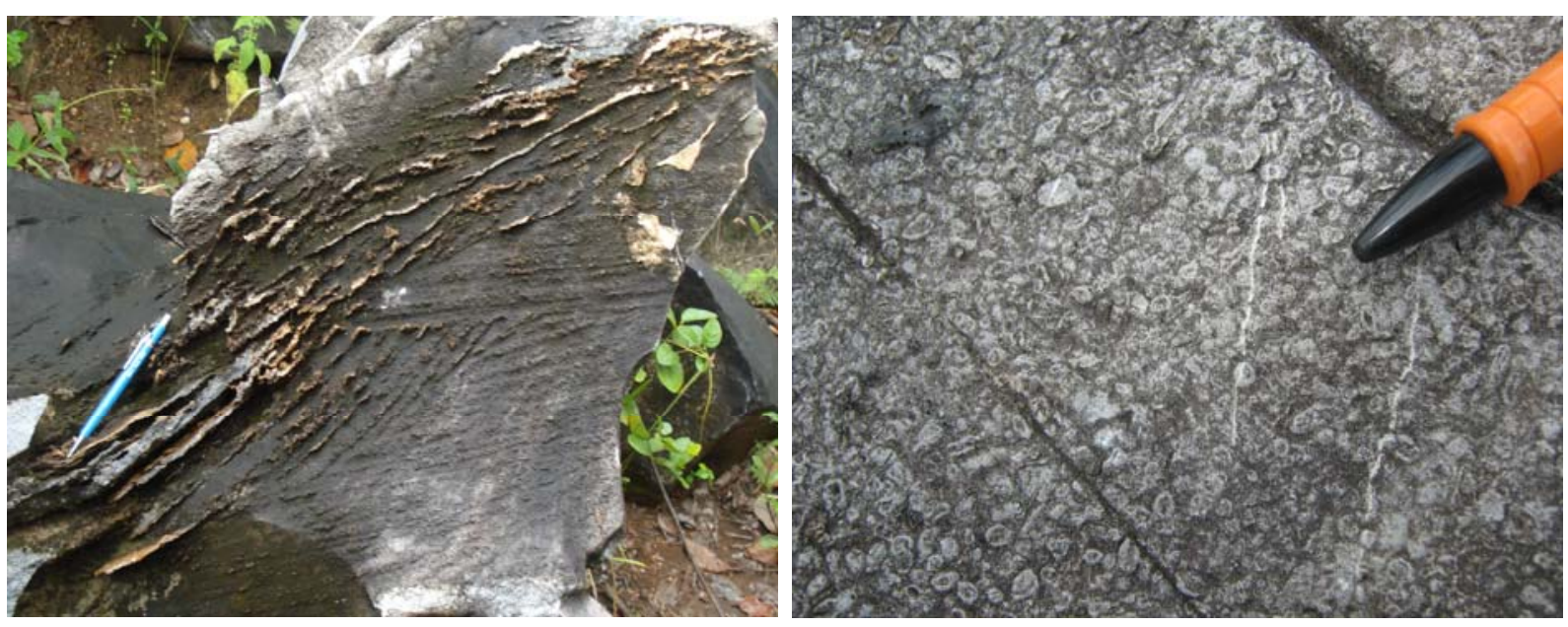

Figura 7.1.9 - Aspecto macroscópico da fácies de grainstone oolítico superior. À esquerda, estratificações cruzadas parcialmente silicificadas e à direita, detalhe da fácies, destacando a textura oolítica. 

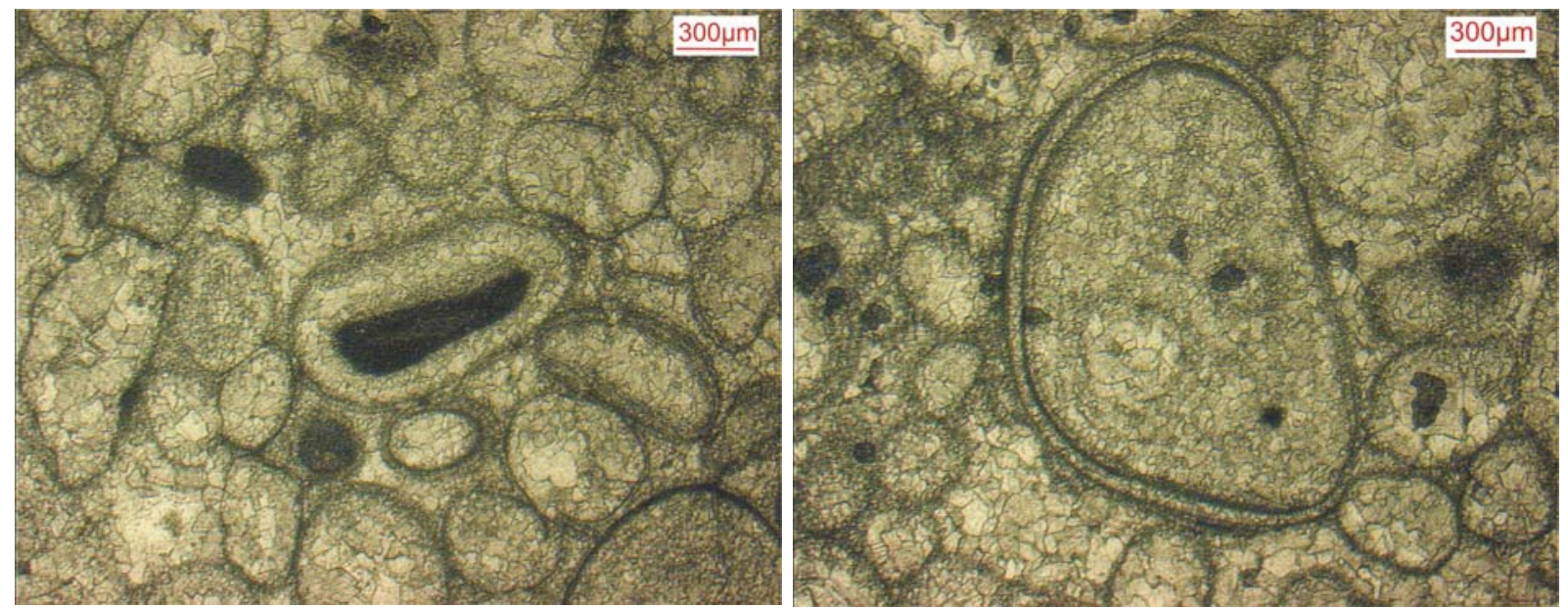

Figura 7.1.10 - Aspecto da fácies de grainstone oolítico superior ao microscópio petrográfico, notar oóides recristalizados e presença de intraclastos micrítico, inclusive como núcleo dos grãos envelopados (à esquerda) e macro-oóide, ou pisóide, com dupla laminação envoltória preservada (à direita).

Interpretação: o ambiente deposicional para a fácies é interpretado como de águas rasas e agitadas devido à presença de oóides. As estratificações cruzadas indicam processos hidrodinâmicos atribuídos à migração do leito sedimentar por ação de correntes. Esta fácies pode ser interpretada como um banco de areias oolítico.

A excelente preservação das estruturas sedimentares, onde os oóides apresentamse bem arredondados e não compactados indica que houve uma rápida cimentação da rocha, ainda na eodiagênese. A textura xenotópica da dolomita sugere que a mesma seja secundária. Provavelmente os oóides eram orginalmente de carbonato de cálcio, foram cimentados também por carbonato de cálcio, e na diagênese foram substituídos por dolomita, como discutido para a fácies de Grainstone oolítico inferior.

As lâminas micritizadas são interpretadas como fruto da ação de bactérias endolíticas durante a diagênese. Essa interpretação não descarta a possibilidade de parte dessas lâminas de coloração preta serem constituídas por matéria orgânica, mas para tal afirmação, seria necessário fazer análise de COT. 


\subsubsection{Fácies de Rudstone Intraclástico}

Amostras: FR-14, 15 e 20.

Descrição: brecha intraformacional de matriz dolomítica cinza claro muito fina, com clastos angulosos de até $5 \mathrm{~cm}$ de comprimento de mudstone. É recorrente ao longo da seção estratigráfica, em níveis restritos de aproximadamente $1 \mathrm{~m}$ de espessura.

Interpretação: comumente, brechas são formadas por processos de fluxo gravitacional, o que implica em desnível topográfico, como exemplo em borda de talude ou mesmo na região de forereef (FRIEDMAN; SANDERS, 1978; DAVIS, 1983). Há brechas de colapso, relacionadas à sistemas cársticos.

No entando, devido à pequena dimensão dos clastos bem como a pouca espessura das brechas, acredita-se que a fácies de Rudstone Intraclástico tenha sido formada em momentos de exposição subaérea, onde o sedimento carbonático previamente depositado, foi exposto, ressecado e rapidamente retrabalhado em períodos de mais umidade.

\subsubsection{Fácies de Rudstone Pisolítico}

Amostras: 09-BOC-22A a E.

Descrição: a fácies de rudstone pisolítico compreende três sub-fácies, que se alternam em aproximadamente $50 \mathrm{~cm}$. Destas sub-fácies foram coletadas cinco amostras estratigraficamente posicionadas (Figura 7.1.11). Na base do bloco, ocorre mudstone maciço (sub-fácies 1) em contato abrupto irregular com rudstone pisolítico com presença de partículas fosfáticas (sub-fácies 2), que se alterna com rudstone pisolítico não fosfatizado (sub-fácies 3). 


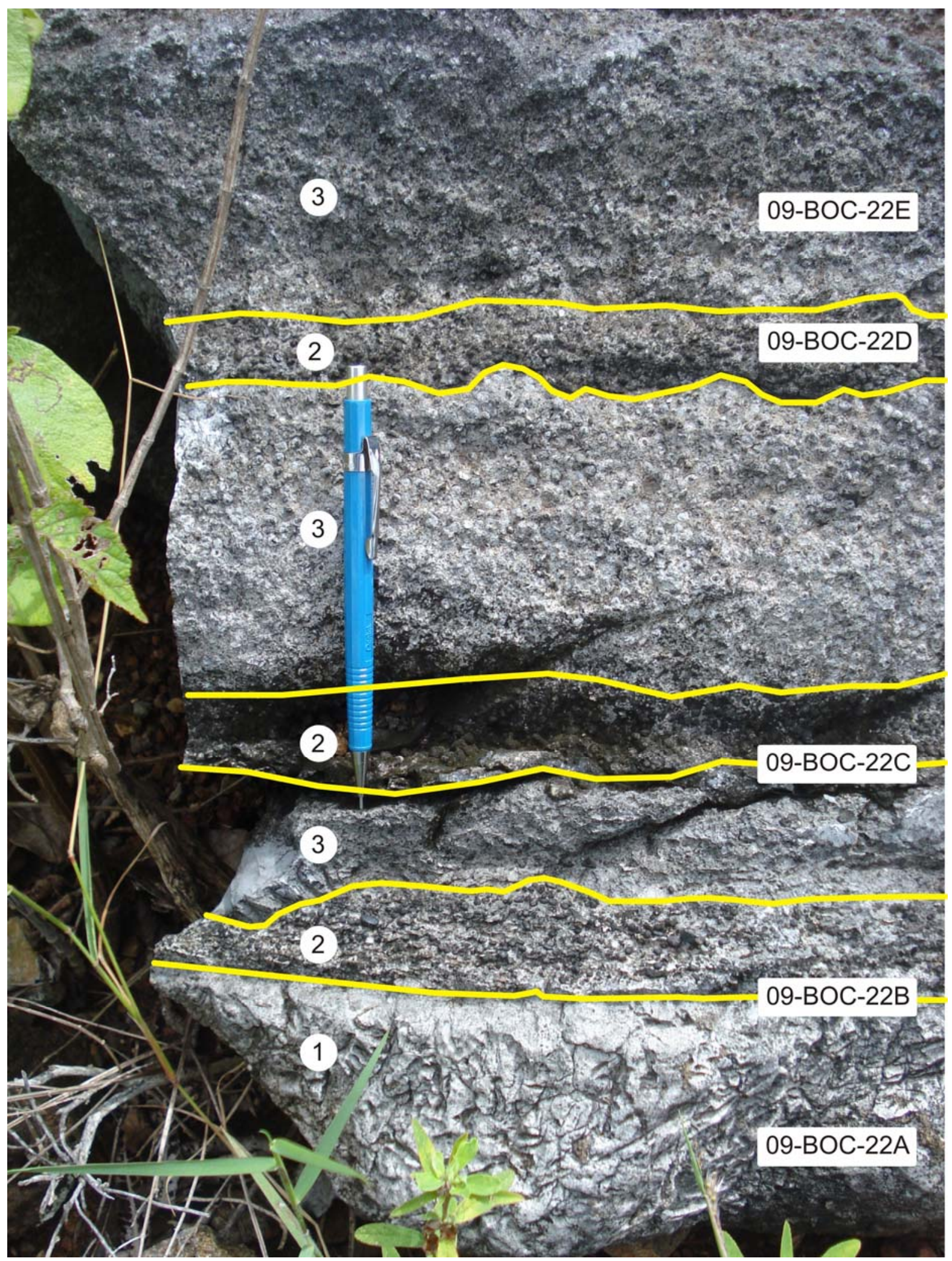

Figura 7.1.11 - Bloco in situ na Fazenda Ressaca, a partir do qual foram definidas as heterogeneidades da fácies de rudstone pisolítico. Os números à esquerda correspondem a: (1) mudstone maciço, (2) rudstone pisolítico com fosfato e (3) rudstone pisolítico não fosfatizado. Observar a alternância das sub-fácies em aproximadamente $50 \mathrm{~cm}$ de espessura do bloco. À direita estão especificadas as amostras coletadas. 
Ao microscópio petrográfico, observa-se porções da micrita recristalizadas e de cimento de dolomita espática. Observa-se também cristais alongados e prismáticos cuja morfologia assemelha-se a pseudomorfos de cristais de gipso, recristalizados como dolomita (Figura 7.1.12). O contato com a sub-fácies 2 é abrupto, irregular e interdigitado, também observado ao microscópio petrográfico (Figura 7.1.12).
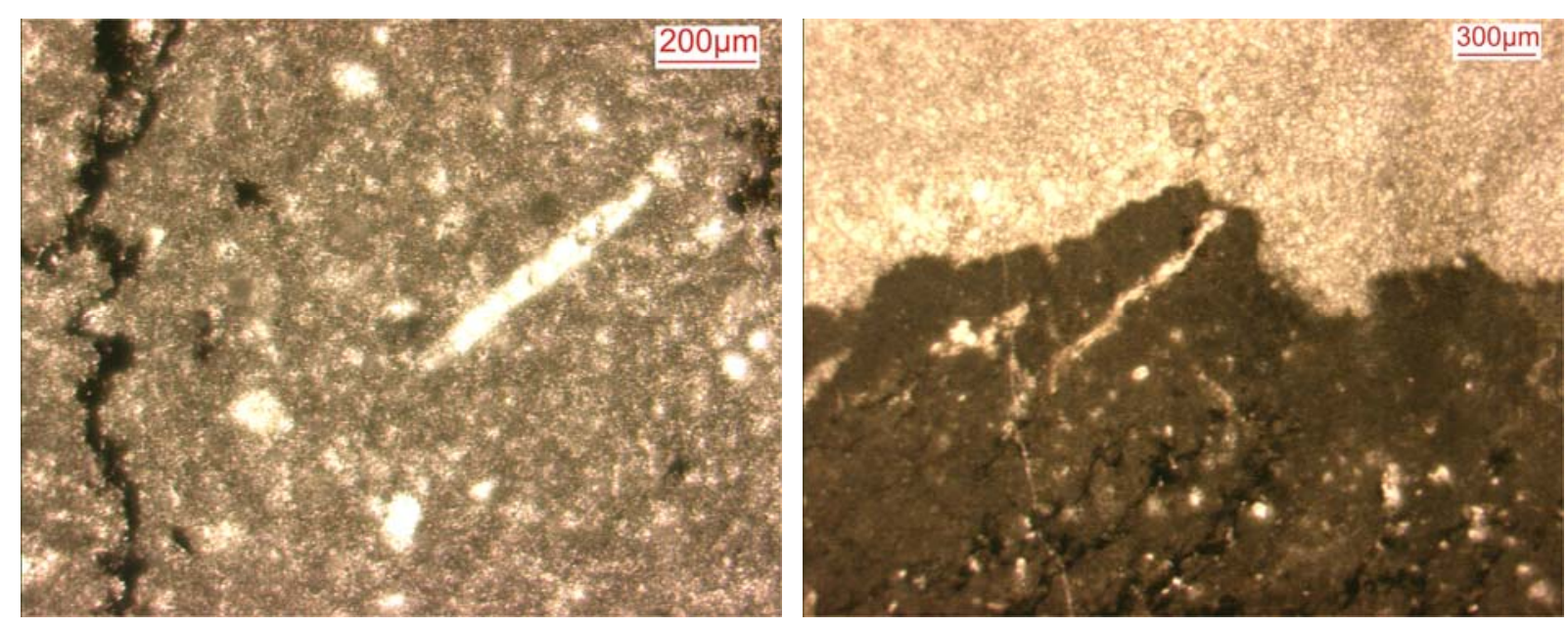

Figura 7.1.12 - À esquerda, cristais prismáticos interpretados como pseudomorfos de cristais de gipso e à direita, contato irregular do mudstone maciço (porção inferior da foto, de coloração mais escura) com rudstone pisolítico com fosfato (porção superior da foto, de coloração mais clara). Nicóis paralelos.

A sub-fácies de rudstone pisolítico com fosfato, macroscopicamente exibe partículas fosfáticas de coloração mais escura (Figura 7.1.13). Microscopicamente, é possível observar grãos revestidos dolomíticos e partículas fosfáticas arredondadas de até $2 \mathrm{~mm}$ de diâmetro, que por vezes possuem laminação irrelugar concêntrica, com porções fosfatizadas, por vezes compreendem apenas pelóides fosfáticos maciços (Figura 7.1.14). Observa-se orientação das partículas fosfáticas. Os grãos revestidos possuem a laminação irregular, aparentemente rompida. Apesar da elevada densidade de grãos revestidos, estes raramente se tocam, estando sustentados por cimento dolomítico espático zonado.

Ao microscópio eletrônico de varredura, é possível discriminar as lâminas fosfáticas das lâminas dolomíticas (Figuras 7.1.15 e 7.1.16). Observa-se que a apatita é criptocristalina, enquanto a dolomita apresenta cristais maiores (Figura 7.1.16). As relações de contato entre as bandas dolomíticas e fosfáticas são de difícil estabelecimento (Figura 7.1.17).

A mineralogia foi confirmada por difração de raios-x como dolomita, apatita e subordinadamente mica (Anexo A - Figura 2). 


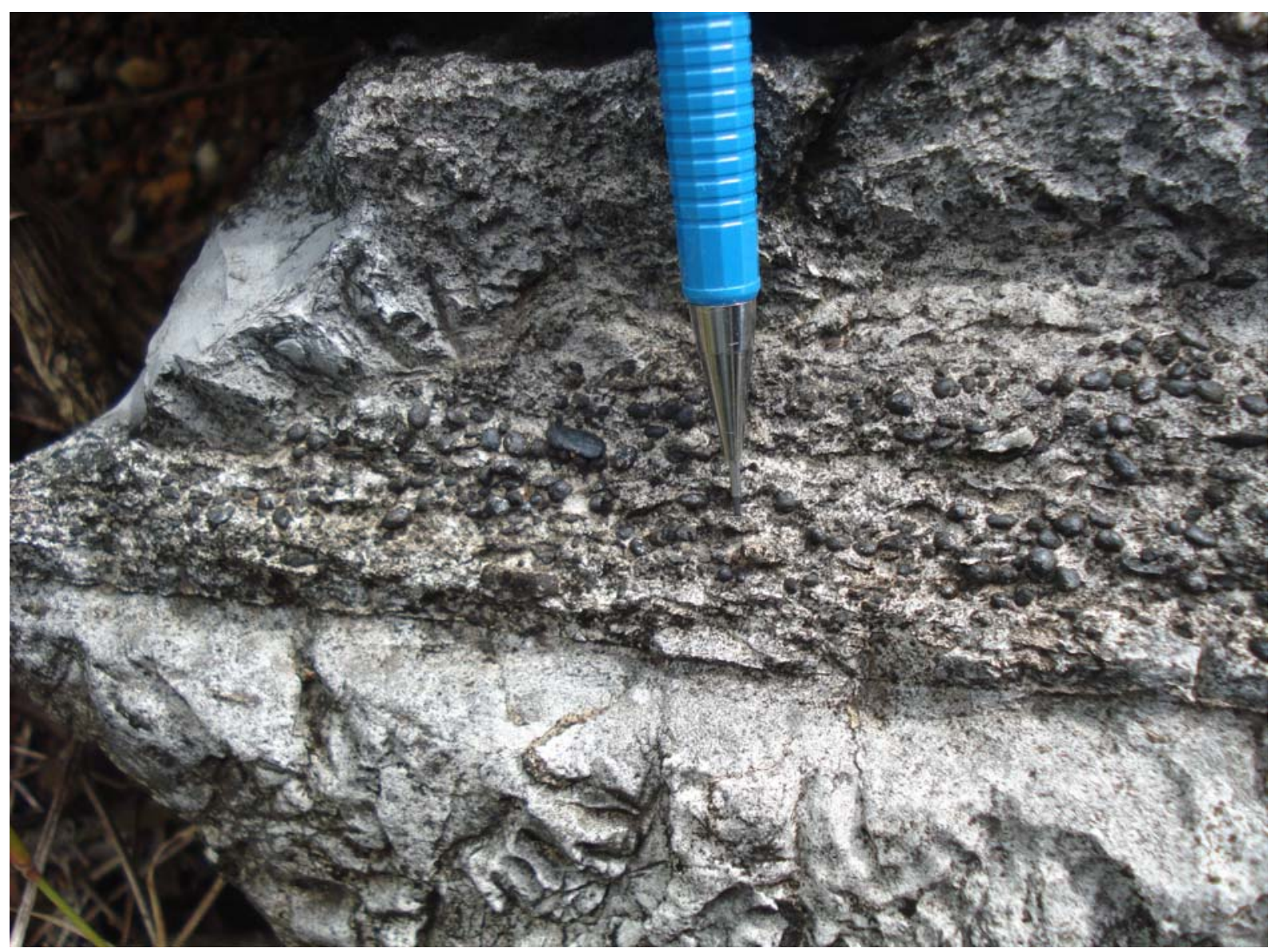

Figura 7.1.13 - Detalhe do contato entre a sub-fácies de mudstone maciço (1, na base) com a subfácies de grainstone pisolítico com fosfato (2, topo). Observar as partículas escuras na sub-fácies 2 , que correspondem às partículas fosfáticas.

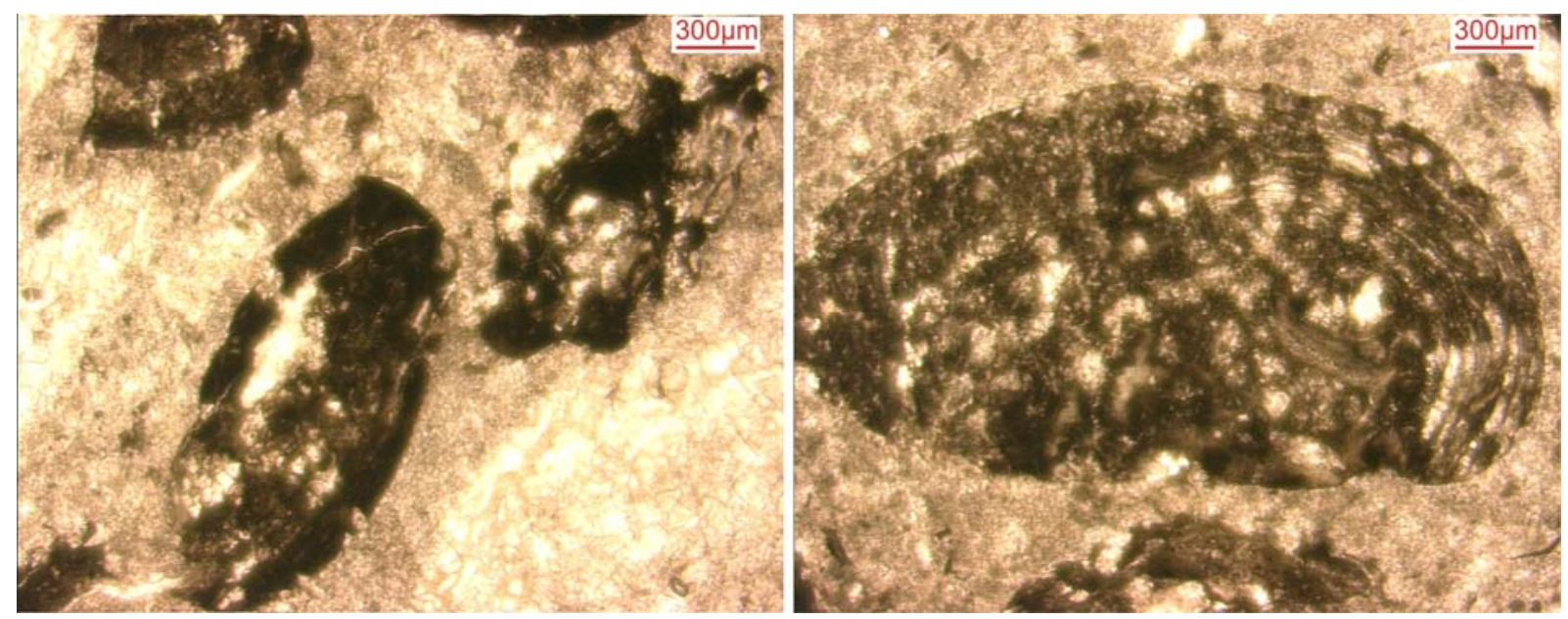

Figura 7.1.14 - Partículas fosfáticas presentes na sub-fácies de grainstone pisolítico com fosfato. À esquerda, possível pelóide fosfático e à direita, grão revestido fosfatizado. 


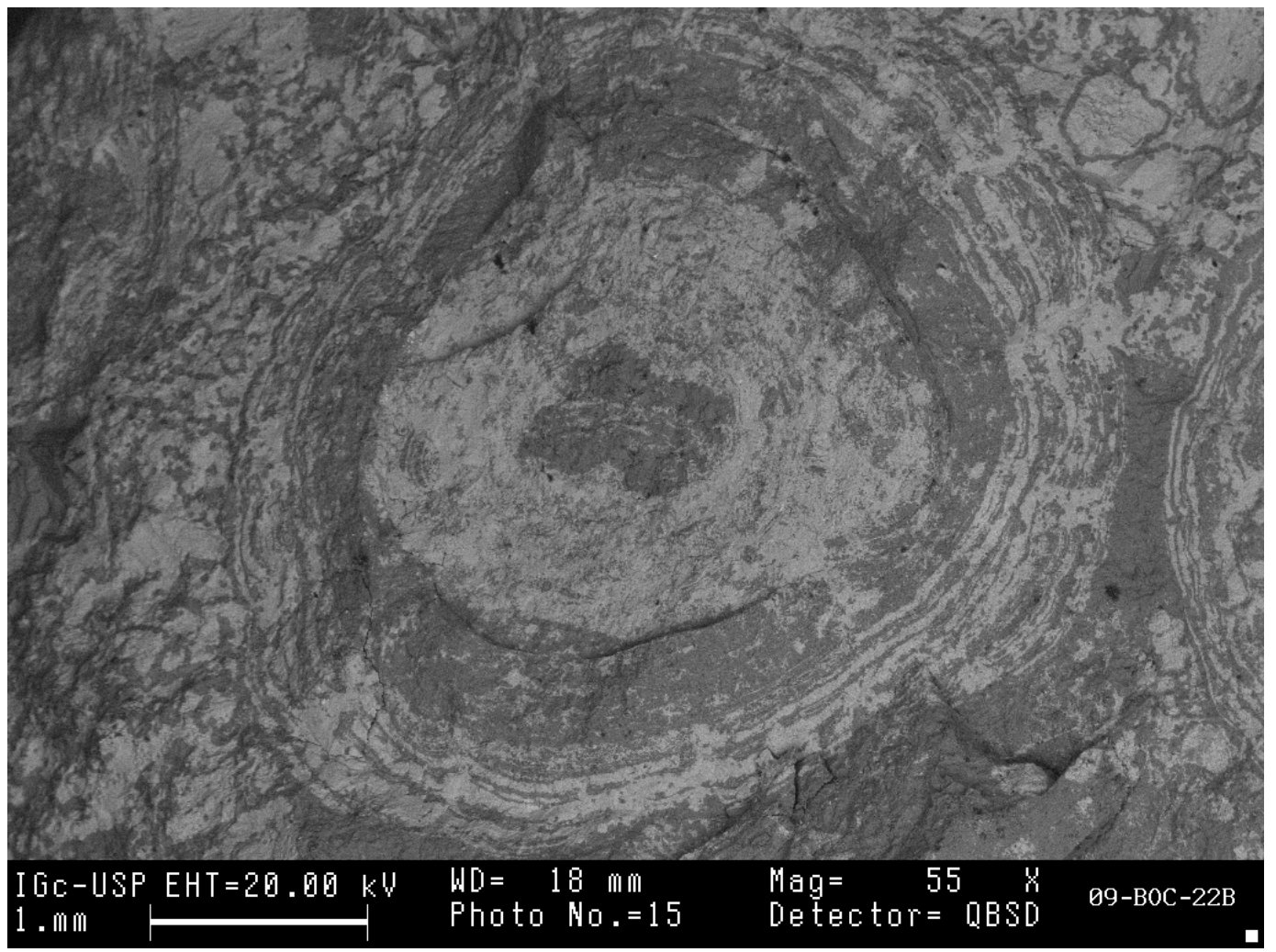

Figura 7.1.15 - Na imagem de MEV pode-se observar o pisólito parcialmente fosfatizado, cujas porções em cinza mais claro representa apatita e em cinza mais escuro, dolomita (variação composicional confirmada no EDS). Observar a irregularidade da laminação.

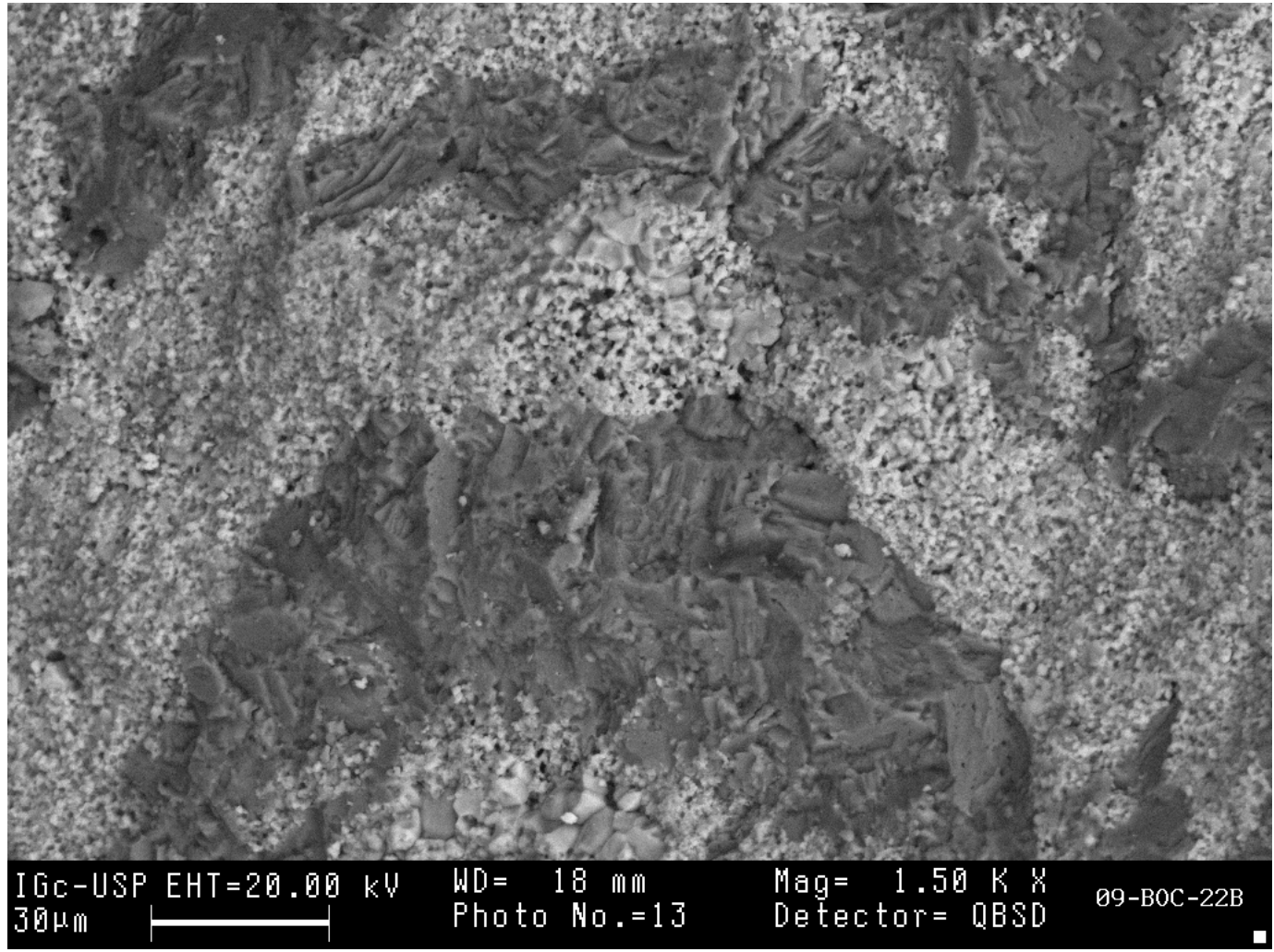

Figura 7.1.16 - Detalhe das lâminas dolomíticas (porção mais escura) e lâminas fosfáticas (porção mais clara). Observar que a apatita é criptocristalina, enquanto a dolomita cristais maiores (imagem de MEV). 


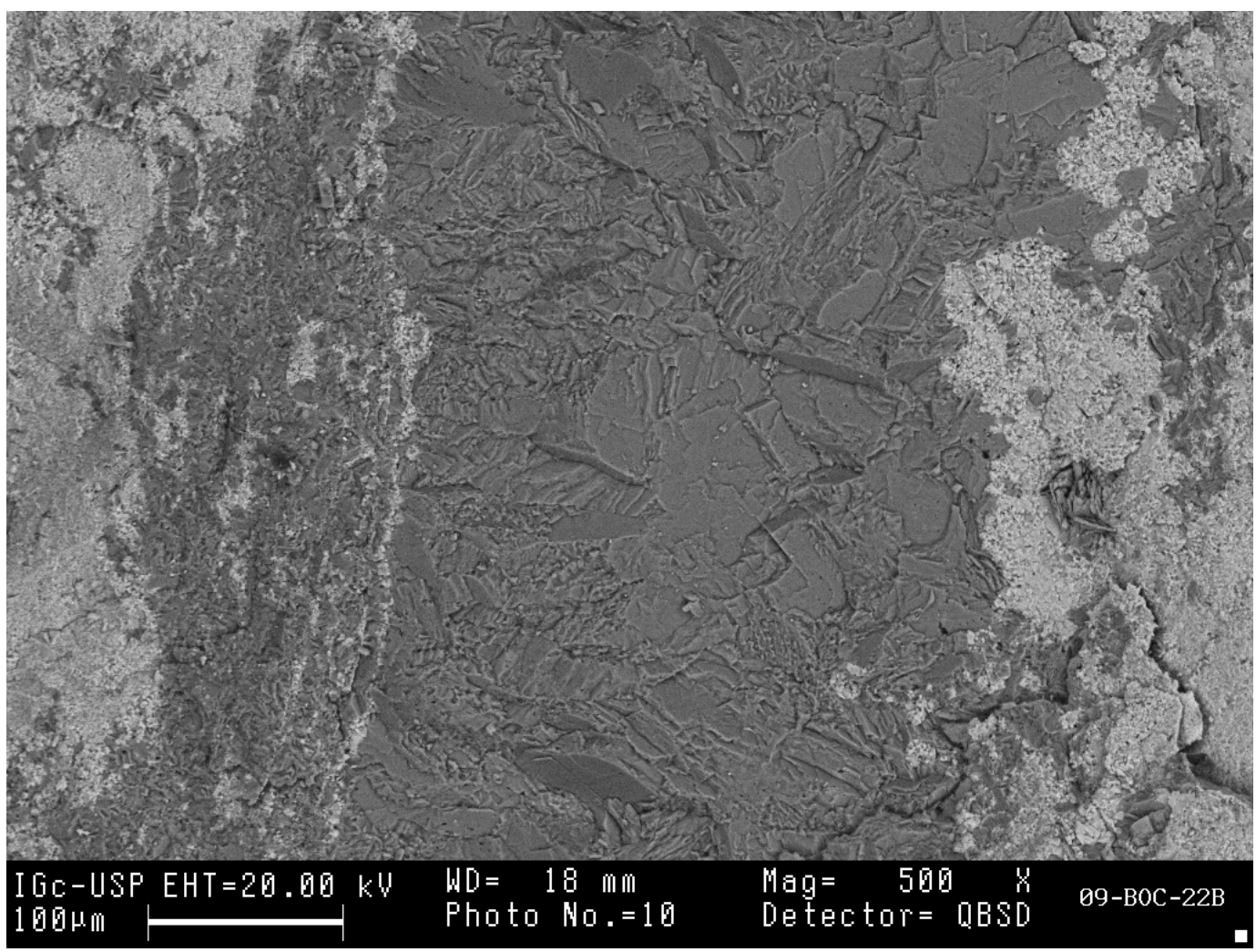

Figura 7.1.17 - Detalhe da banda dolomítica (ao centro da imagem, cinza mais escura) em contato com as porções fosfatizadas (cinza mais claro) (imagem de MEV).

A sub-fácies 3, de rudstone pisolítico não-fosfatizado (Figura 7.1.18), é composta por grãos envelopados com dimensões superiores aos encontrados sub-fácies 2, cujo diâmentro é em média de $1 \mathrm{~mm}$, podendo atingir até $2,5 \mathrm{~mm}$, com laminação finamente crenulada e irregular (Figura 7.1.19). Entre as lâminas dos grãos envelopados, observa-se a ocorrência de matriz micrítica aprisionada (Figura 7.1.19). em geral, os grãos revestidos não se tocam.

Entre os pisóides, observadas três fases de cimentação (indicadas como $A, B$ e C na Figura 7.1.20): a primeira fase (A) é de cimento dolomítico com textura em franja próximo a borda do grão, seguida por uma segunda fase de cimento dolomítico também em franja (B) e por fim, no centro do antigo poro, ocorre cimento de dolomita espática (C).

Por difração de raios-x, a mineralogia identificada é exclusivamente dolomítica (Anexo A - Figura 2). As lâminas mais escuras, observadas na petrografia, possivelmente estão micritizadas. 


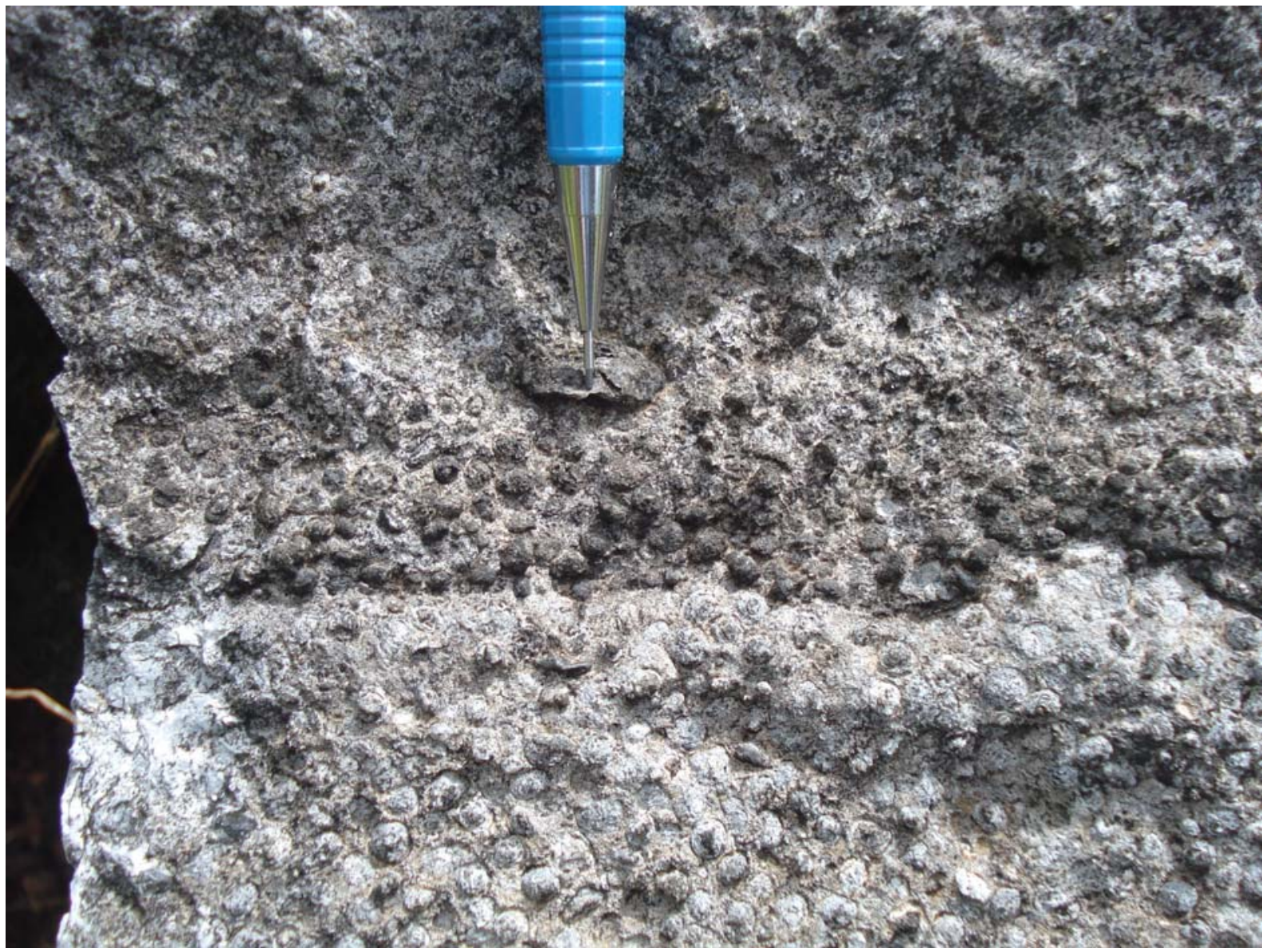

Figura 7.1.18 - Aspecto macroscópico da sub-fácies de rudstone pisolítico não-fosfatizado. Observar a elevada densidade de pisódes que raramente estão em contato.
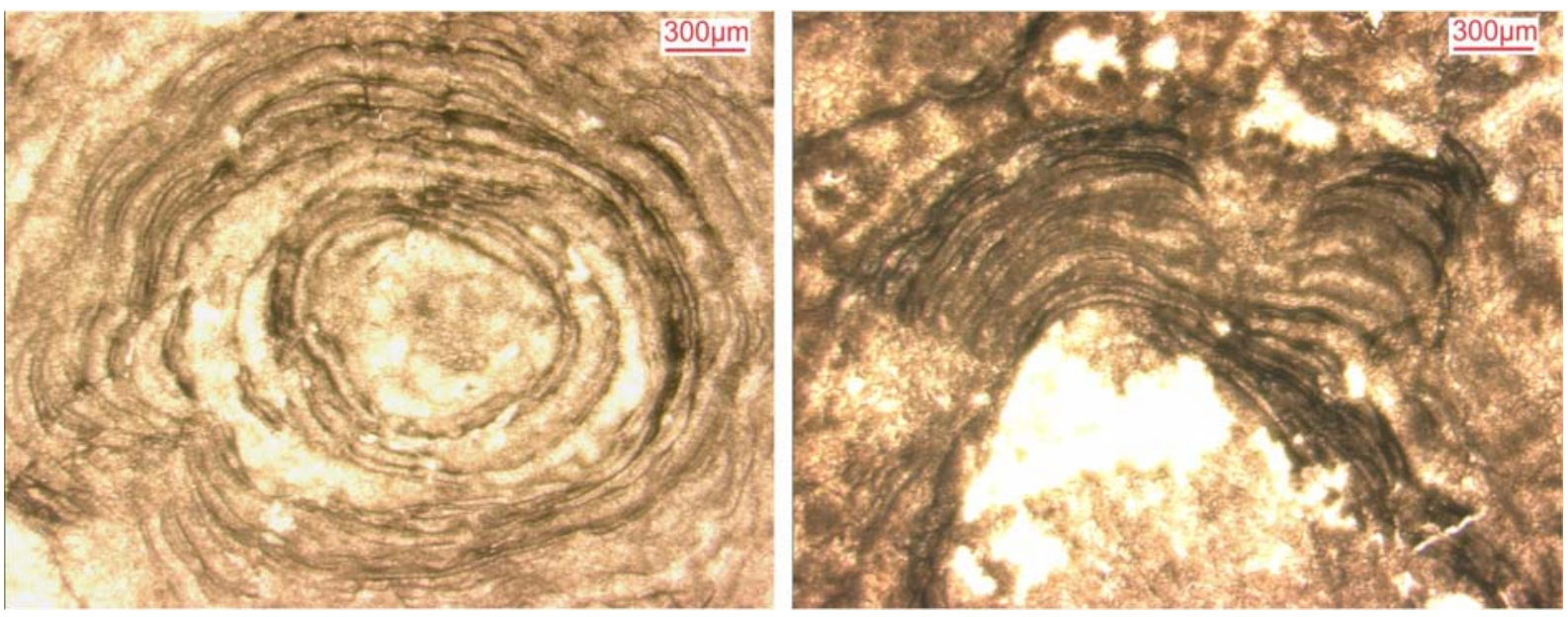

Figura 7.1.19 - Pisóides visto ao microscópio petrográfico. Observar a laminação irregular, crenulada e interrompida. Notar a matriz micrítica aprisionada entre as lâminas do grão revestido. 

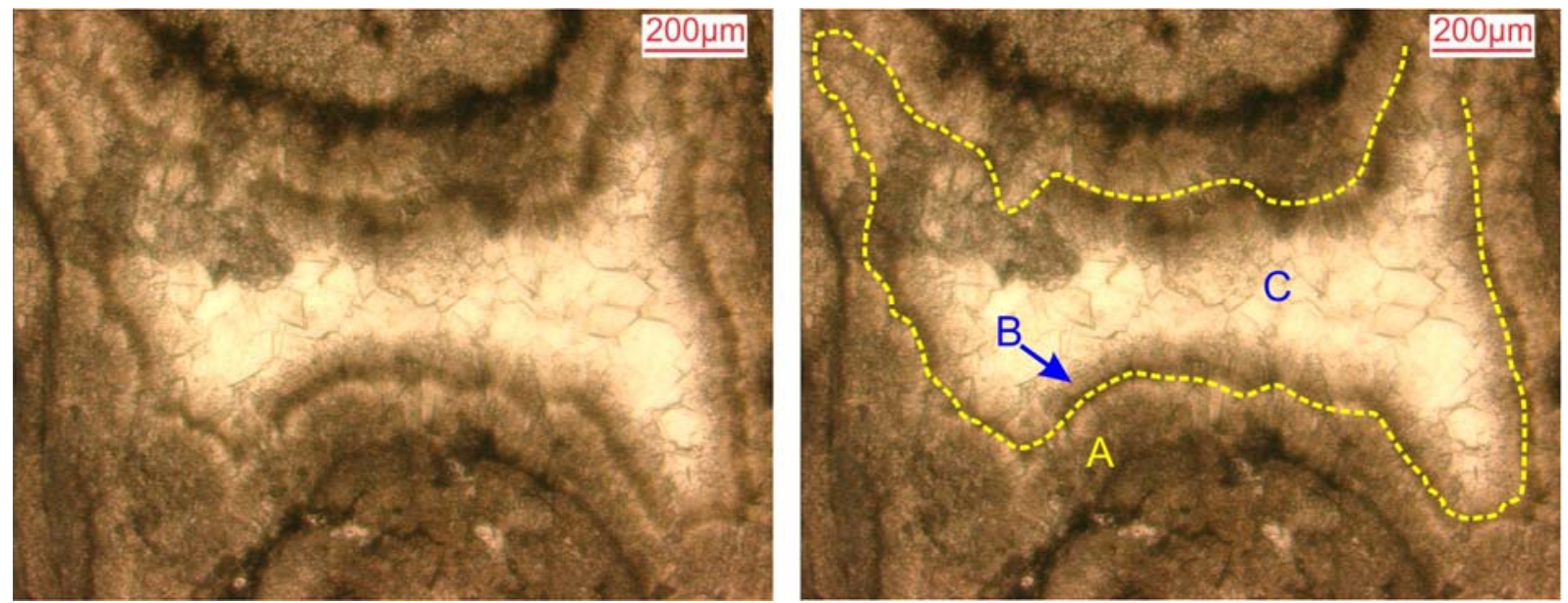

Figura 7.1.20 - Detalhe do cimento entre os pisóides. Na imagem da direita são destacadas as três fases de cimentação dolomítica observada ao microscópio petrográfico: (A) primeira fase de cimentação em franja, (B) segunda fase de cimentação também em franja (separada da primeira fase pela linha tracejada em amarelo) e (C) fase final de cimentação espática no centro do antigo poro.

Observa-se também porções onde ocorre matriz micrítica entre os fantasmas de grãos revestidos (Figura 7.1.21 à esquerda). Por vezes está associada à camadas de mudstones rompidas e levemente dobradas. (Figura 7.1.21 à direita).
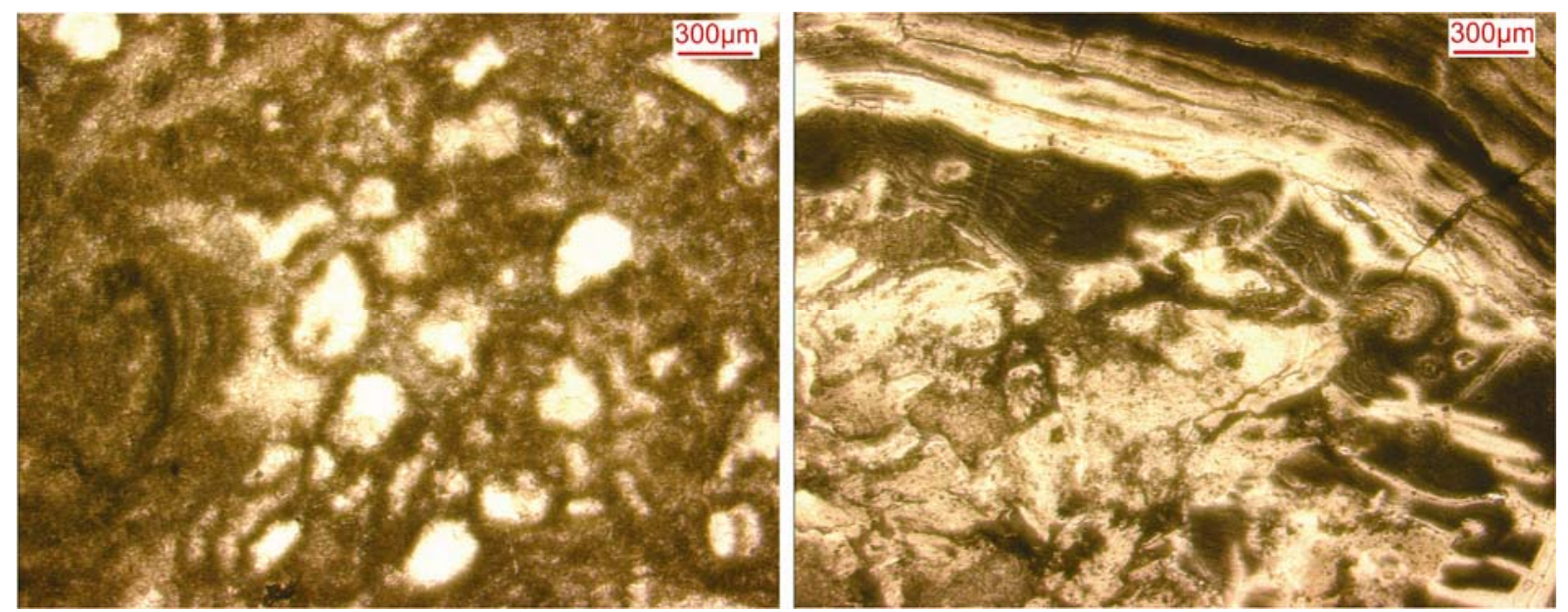

Figura 7.1.21 - À esquerda, matriz micrítica entre os "fantasmas de grãos revestidos", e à direita, observa-se níveis de mudstone dolomítico rompido e levemente dobrado com fina laminação planoparalela.

Interpretação: pisóides são grãos revestidos cuja gênese está relacionada à ação de microorganismos originados abaixo da interface sedimento/água (PERYT, 1983).

Para os pisóides da Formação Bocaina interpreta-se que foram formados na interface das zonas vadosa, especialmente pela presença de cimento em franja. A micritização das lâminas pisolíticas são características da ação de microorganismos endolíticos (TUCKER, 2001). 
Considerando a origem em zona vadosa, os pisólitos da Formação Bocaina podem ser denominados de vadóides. Os vadóides são encontrados nos mais diversos ambientes, como lacustres, fluviais, marinhos e pedogenéticos (PERYT, 1983).

A composição dolomítica dos grãos revestidos e também do cimento pode ser interpretada de duas maneiras: (1) a dolomita é eodiagenética, formada por precipitação bioinduzida ou (2) a dolomita é secundária, formada por substituição do carbonato de cálcio original (calcita ou dolomita), na eodiagênese por percolação de fluidos meteóricos, possivelmente em momentos de exposição subaérea.

Considera-se mais provável que a dolomita tenha se formado da segunda maneira já que os cristais são muito límpidos e de dimensões superiores a $10 \mu \mathrm{m}$ para serem formados por bioindução.

Os níveis preferencialmente fosfatizados podem ser explicados pela variação da zona ativa de fosfogênese, dentro da coluna de sedimentos, como indicado por Pufahl \& Grimm (2003) (Figura 7.1.22). Os autores discorrem sobre a formação de grãos revestidos de apatita autigênica, formados dentro de sedimentos ricos em matéria orgânica. A degradação da matéria orgânica seria responsável por enriquecer as águas intersticiais em fósforo. Se a taxa de sedimentação for muito elevada, os grãos são removidos desta zona e rapidamente retrabalhados, podendo retornar para a zona ativa e dar continuidade ao processo de precipitação de apatita. Considera-se que os grãos revestidos de fosfato representam o equivalente à superfícies condensadas, já que sua formação requer longo tempo de residência abaixo da interface sedimento/água (PUFAHL; GRIMM, 2003).

Para os vadóides com níveis preferencialmente fosfatizados da Formação Bocaina, interpreta-se que poderia ter ocorrido um processo semelhante, onde a apatita precipitou-se nas lâminas com maior concentração de matéria orgânica devido à variação da zona ativa de fosfogênese na coluna de sedimentos na interface das zonas vadosa/freática.

O contato entre as sub-fácies de mudstone maciço e a de grainstones pisolíticos (Figura 7.1.12) é irregular e sugere uma superfície de dissolução. Estas superfícies podem se formar por sucessivas etapas de exposição subaérea e entrada de água meteórica.

As camadas de mudstone rompidas e dobradas (Figura 7.1.21), observadas em microscópio petrográfico, são interpretadas como vestígios de esteiras microbianas, devido à laminação plano-paralela irregular. Estas evidências, somadas aos prováveis pseudomorfos de cristais de gipso (Figura 7.1.12), sugerem que estas camadas representem estrutura tipo tepee, que implica em condição climática árida a semiárida com exposição subaérea, recorrente em ambientes de supramaré.

Assim, considera-se que a fácies de grainstone pisolítico foi originada em zona vadosa, na qual houve a formação in situ dos grãos revestidos (vadóides), provavelmente de 
carbonato de cálcio e posteriormente substituídos por dolomita devido a exposições subaéreas e entrada de águas meteóricas. Os níveis preferencialmente fosfatizados correspondem às lâminas mais ricas em matéria orgânica que foram convertidas para apatita na eodiagênese por variações geoquímicas na interface das zonas vadosa/freática.

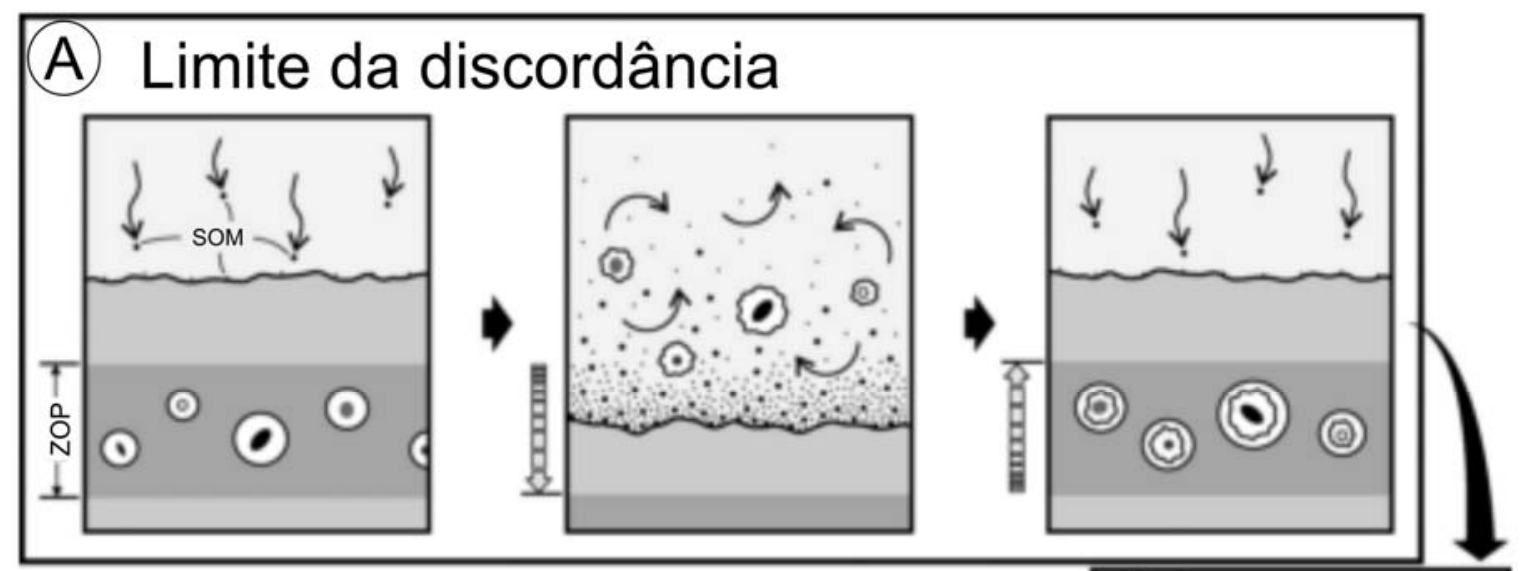

B) Agregado redox
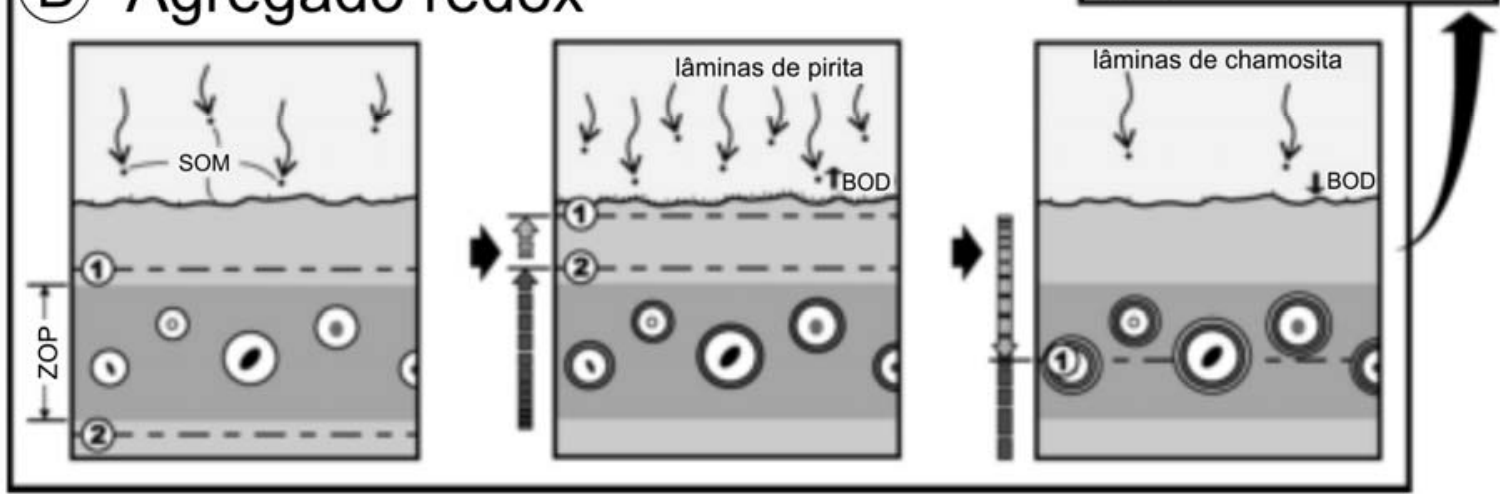

Figura 7.1.22 - Formação de grãos revestidos fosfáticos. A zona ativa de precipitação de fosfato (ZOP) ocorre nos $5-20 \mathrm{~cm}$ superficiais de sedimento. Em zonas de elevada produtividade, a fosfogênese é estimulada primariamente pela produção de fosfato nas águas intersticiais derivada da degradação microbiana, em zona subóxica, nos sedimentos ricos em matéria orgânica (SOM). Isso ocorre em associação com a redução de $\mathrm{NO}_{3}{ }^{-}, \mathrm{SO}_{4}{ }^{2-}$ e dos óxidos de $\mathrm{Mn}$ e $\mathrm{Fe}$, sendo limitada nos intervalos mais profundos pela falta de $\mathrm{F}^{-}$derivado da água do mar e a elevada alcalinidade decorrente da degradação acumulativa da matéria orgânica. (A) Formação de limites de discordâncias de grãos fosfáticos. Ciclos de erosão e deposição ocasionados pela migração da ZOP na coluna de sedimentos. (B) Formação de grãos agregados fosfáticos redox. O fluxo episódico de carbono orgânico para o fundo oceânico faz a interface redox deslocar-se verticalmente nos sedimentos através ZOP em resposta a mudanças na demanda biológica de oxigênio (BOD). O tipo da laminação depende da quantidade de matéria orgânica e a composição dos sedimentos. 1= interface redox $\mathrm{Fe}^{3+}-\mathrm{Fe}^{2+} ; 2=$ interface redox $\mathrm{SO}_{4}{ }^{2-}-\mathrm{H}_{2} \mathrm{~S}$. (C) Grãos híbridos formados quando ambos os processos agem juntos [modificado de Pufahl \& Grimm (2003)]. 


\subsubsection{Fácies de Fosforito}

Amostras: FR-21, 22, 23, 24 e 09-BOC-21C.

As fácies de fosforitos da Fazenda Ressaca são diversificadas, como apresentado por Justo (2000), porém, no levantamento realizado neste presente trabalho, não foi possível observar grandes exposições in situ, apenas pequenos afloramentos que permitiram ao menos a coleta de amostras com posicionamento estratigráfico.

No topo da seção levantada da Fazenda Ressaca, ocorrem blocos de fosforitos alinhados de forma que sugerem a presença de camada de $10 \mathrm{~m}$ de espessura. Cinco amostras coletadas possuem controle estratigráfico e as demais foram coletadas na superfície, de forma aleatória, mas representam o corpo de rocha fosfática ali presente, cuja investigação petrográfica demonstra diversidade faciológica do depósito.

\subsubsection{Fosfalutito}

O litotipo predominante entre os tipos de fosforito corresponde ao fosfalutito estratificado, com porções estromatolíticas. Possui cor preta, quando fresca, e esbranquiçada, amarelada quando alterada, correspondente ao que Justo (2000) definiu como fosfato do tipo chert. Esse termo não é adequado, já que chert é um tipo de silexito, mas o autor utilizou-o para referir-se ao aspecto do fosforito, preto e fosco, com fraturas conchoidais, semelhante às rochas silicosas.

Ao microscópio petrográfico, o fosfalutito apresenta textura maciça, composta de uma massa amarronzada muito fina, isótropa a nicóis cruzados. Apresenta-se toda entrecortada por veios, preenchidos por calcedônia cripto-cristalina (Figura 7.1.23). Em algumas partes, a massa aparenta que foi dissolvida, restando apenas aglomerados, cujos interstícios foram preenchidos por argilominerais de baixa birrefringência, dispostos em arranjos fibrorradiados.

A amostra 09-BOC-21C exibe matriz fosfática afanítica, inclusive isótropa a nicóis cruzados o que demonstra o baixo grau de cristalinidade, apresenta fenocristais prismáticos, de até $1 \mathrm{~cm}$ de comprimento, que possivelmente representam pseudomorfos de gipso (Figura 7.1.24).

A mineralogia do fosfalutito, por difração de raios-x, é exclusivamente apatita, como observado no Anexo A, Figura 3. 

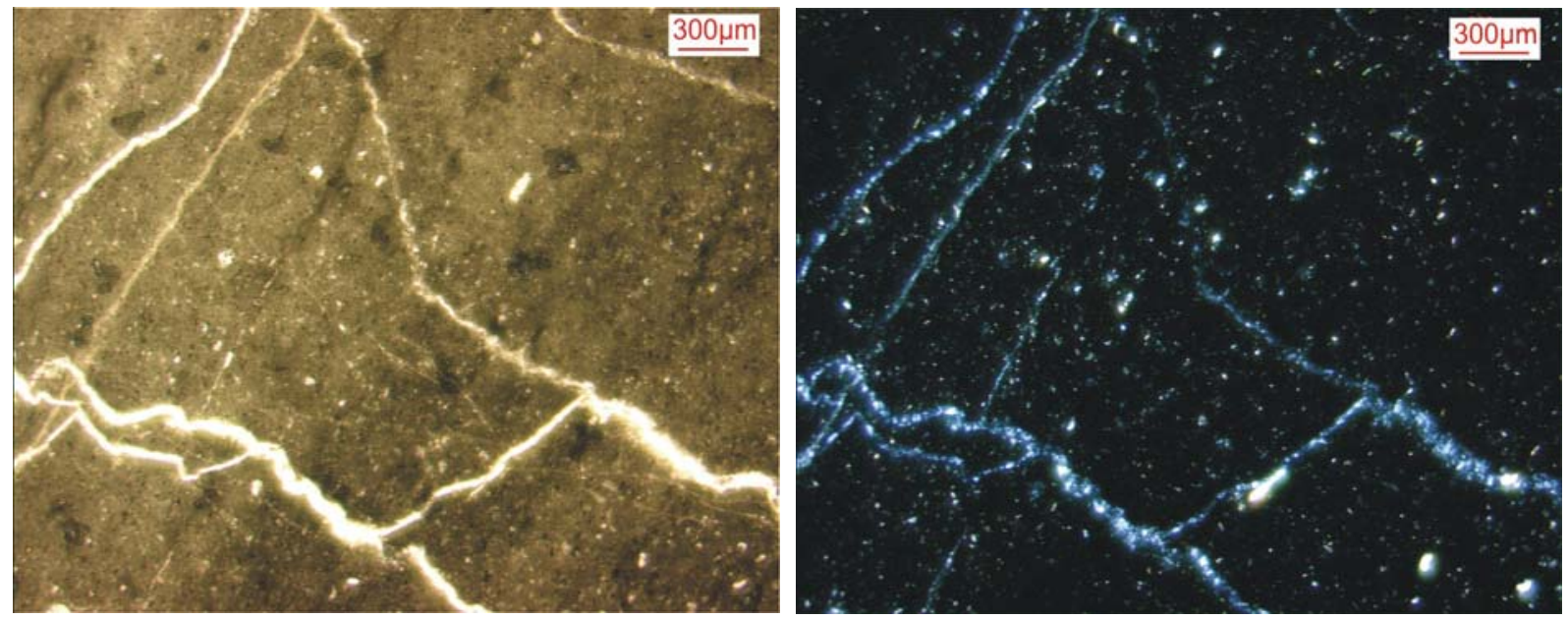

Figura 7.1.23 - Aspecto do fosfautito com veios preenchidos por calcedônia (nicóis paralelos à esquerda e nicóis cruzados à direita).

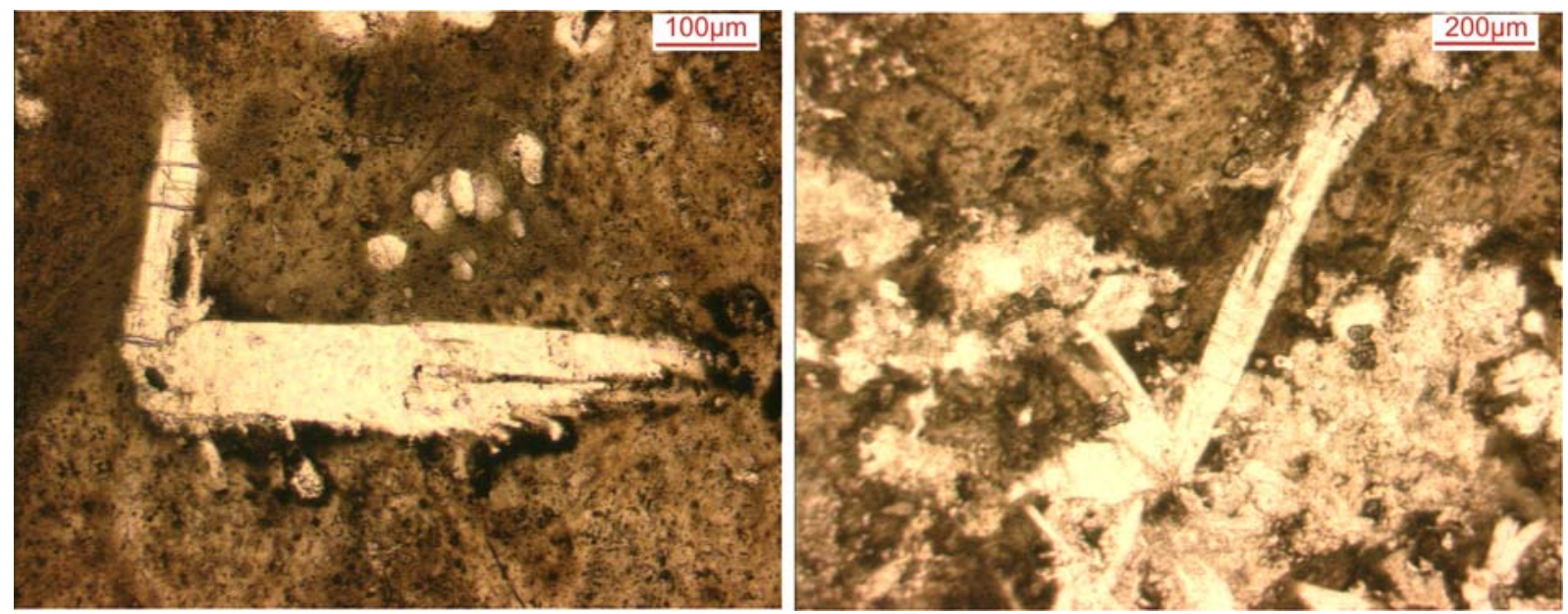

Figura 7.1.24 - Possíveis pseudomorfos de gipso disposto em matriz fosfática afanítica. Observar padrão característico da geminação do mineral: à esquerda, geminação em cotovelo e à direita, arranjo radial dos cristais.

Análise ao microscópio eletrônico de varredura de amostra das rochas fosfáticas demonstram textura microcristalina muito fina (aproximadamente $1 \mu \mathrm{m}$ de diâmetro dos cristais de apatita), com presença de estruturas globulares, de formas esféricas, com $10 \mu \mathrm{m}$ de diâmetro, estruturadas por arranjo de cristais euédricos hexagonais em textura botrioidal com tamanhos por volta de $2 \mu \mathrm{m}$ (Figura 7.1.25).

São encontradas formas elipsoidais com abertura hexagonal em uma extremidade e comprimento de por volta $40 \mu \mathrm{m}$ de comprimento e $10 \mu \mathrm{m}$ de largura (Figura 7.1.26) com textura poligonal hexagonal, semelhante a escamas, na parede interna (Figura 7.1.27).

Ainda por análise de MEV, pôde-se observar filamentos de aproximadamente $3 \mu \mathrm{m}$ de largura e $300 \mu \mathrm{m}$ de comprimento, aparentemente cilíndricos, que cortam a rocha. Alguns deles parecem estar encrustados por cristais de apatita (Figura 7.1.28), enquanto outros são nitidamente superficiais o que leva à a dúvida se seriam estruturas fossilíferas ou apenas uma contaminação da rocha por formas atuais. 

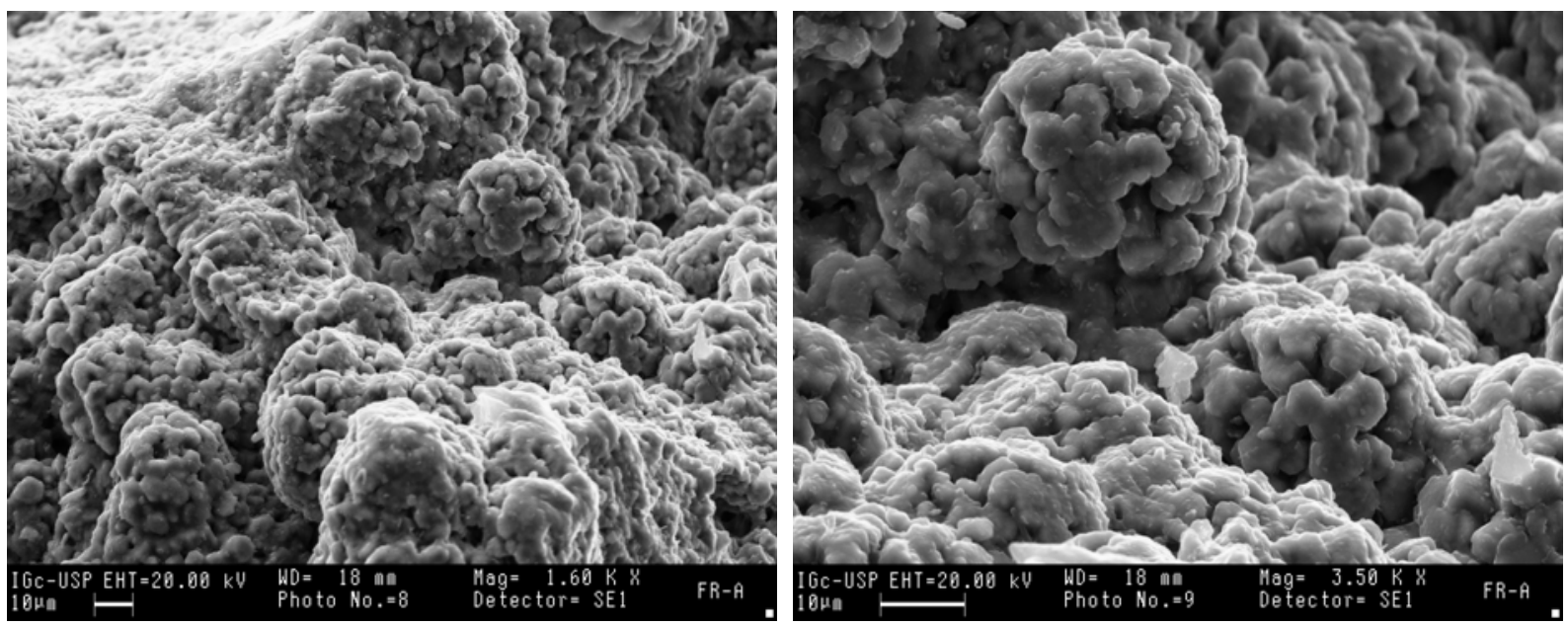

Figura 7.1.25 - Estruturas globulares constituídas de apatita, de formas esféricas, com $40 \mu \mathrm{m}$ de diâmetro, estruturadas por arranjo de cristais euedrais hexagonais com tamanhos por volta de $2 \mu \mathrm{m}$ (imagens obtidas por MEV, a direita detalhe da imagem da esquerda).
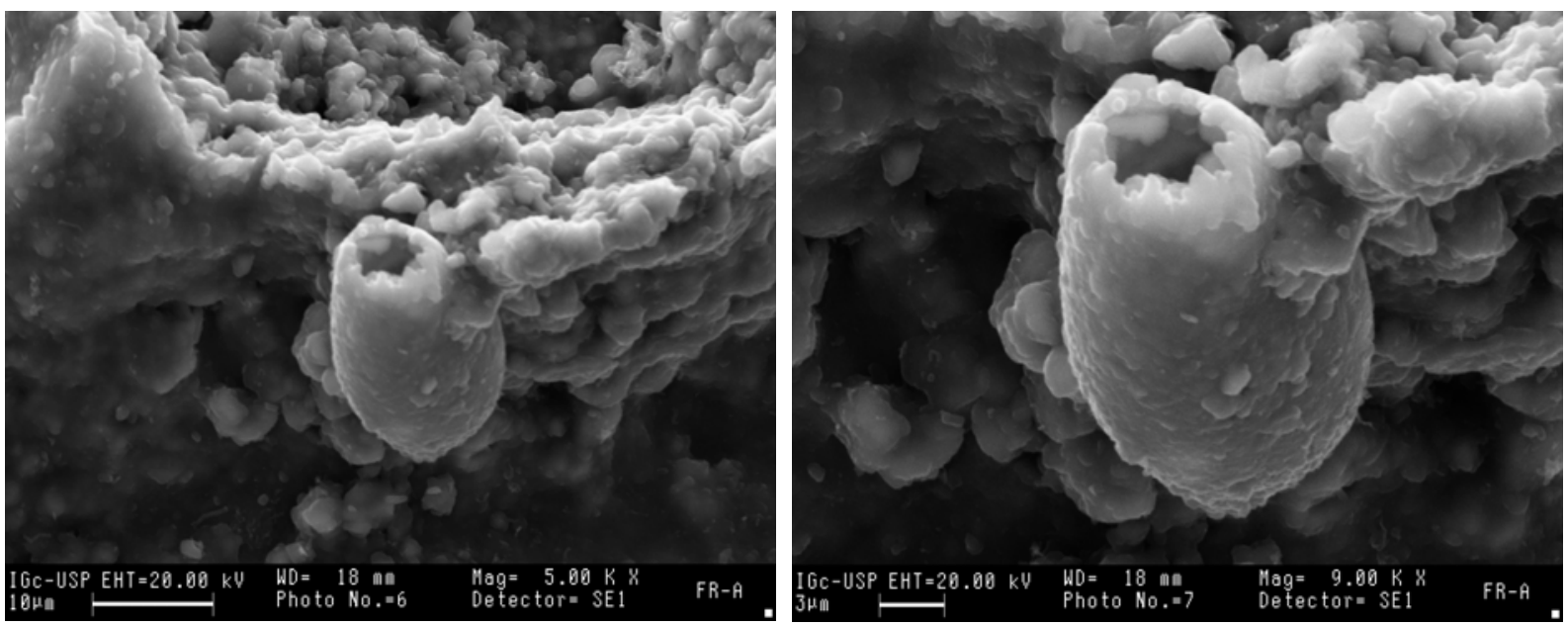

Figura 7.1.26 - As imagens obtidas por MEV mostram possíveis estruturas fossiliferas encontradas no fosforito da Fazenda Ressaca.
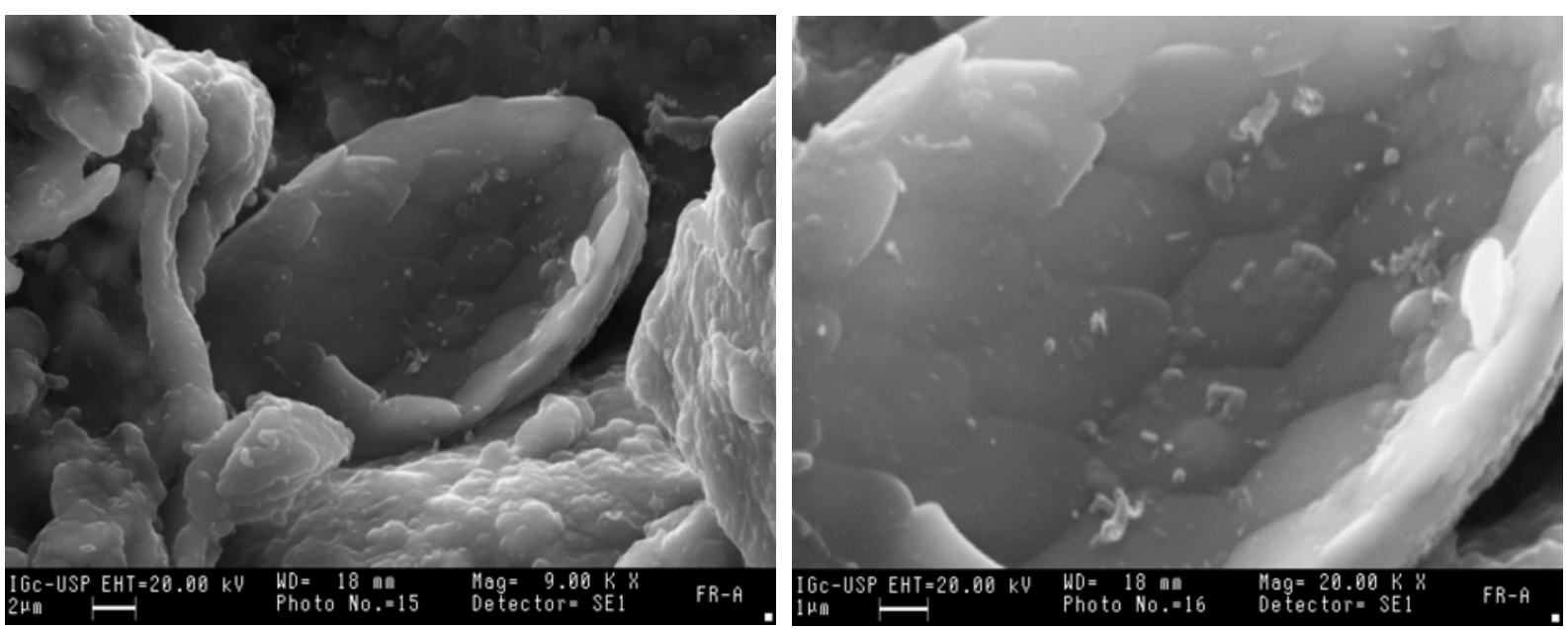

Figura 7.1.27 - Possível estrutura fossilífera encontradas no fosforito da Fazenda Ressaca partida ao meio, destacando arranjo poligonal da parede interna (imagem obtida por MEV). 

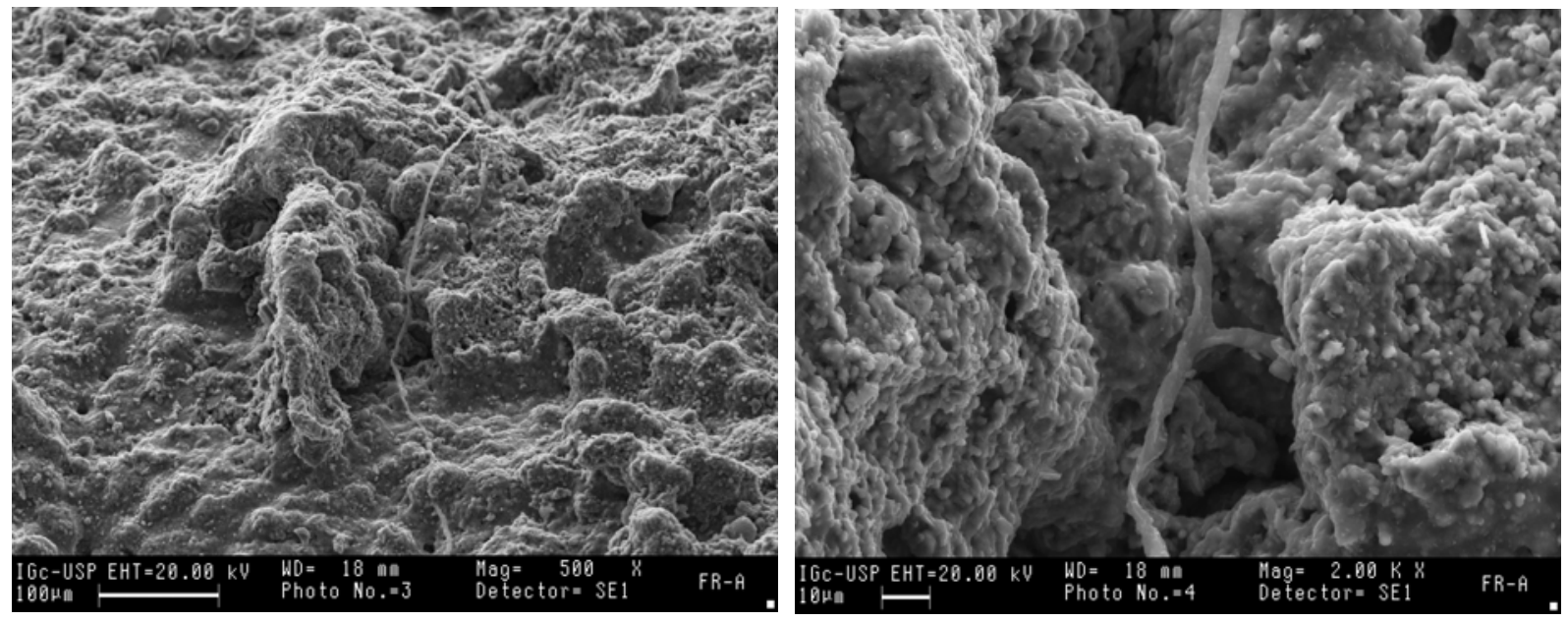

Figura 7.1.28 - Filamentos de possíveis estruturas fossiliferas. À direita, detalhe da imagem da esquerda (imagens obtidas por MEV).

\subsubsection{Fosforito "alongado"}

O nome fosforito "alongado" para esta variedade de fosforito foi aplicada informalmente devido à textura das partículas fosfáticas e a dificuldade de identificar e precisar qual a origem da mesma.

Macroscopicamente, é muito semelhante ao fosfalutito, porém em seção delgada foi possível constatar a presença de partículas arredondadas e alongadas de até $300 \times 600 \mu \mathrm{m}$, eventualmente com laminação concêntrica não muito nítida, que podem se tratar de pisóides ou pelóides fosfáticos. O contato entre as partículas não é nítido, talvez em função da presença de cimento de material semelhante ao das partículas (Figura 7.1.29).

As amostras apresentam nítida estratificação, decorrente do alinhamento e estiramento das partículas. Em alguns níveis, em média com $1 \mathrm{~mm}$ de espessura, é possível observar micro-brechas intraformacionais.

Algumas partículas encontram-se estiradas na forma de bastonetes alongados, alguns com laminação finamente crenulada (Figura 7.1.29), podendo se tratar de oncóides.

Observa-se poros alongados, tipo fenestral, com borda irregular de $1 \mathrm{~mm}$ de comprimento e 0,4 $\mathrm{mm}$ de largura, cujo envoltório é composto por uma lâmina fina de apatita acicular, seguida de uma lâmina de óxidos-hidróxidos de ferro e preenchidos por argilominerais e/ou dolomita espática (Figura 7.1.30).

Pode-se observar também, que algumas partículas foram totalmente dissolvidas, restando apenas o cimento que as envolvia. Parte destes poros foi preenchida por sílica microcristalina ou apatita euédrica (Figura 7.1.30). 
Por difração de raios- $x$, a mineralogia identificada para as amostras FR-22 e FR-24 é praticamente apatita, observando picos subordinados de quartzo para a amostra FR-22 (Anexo A - Figura 3).
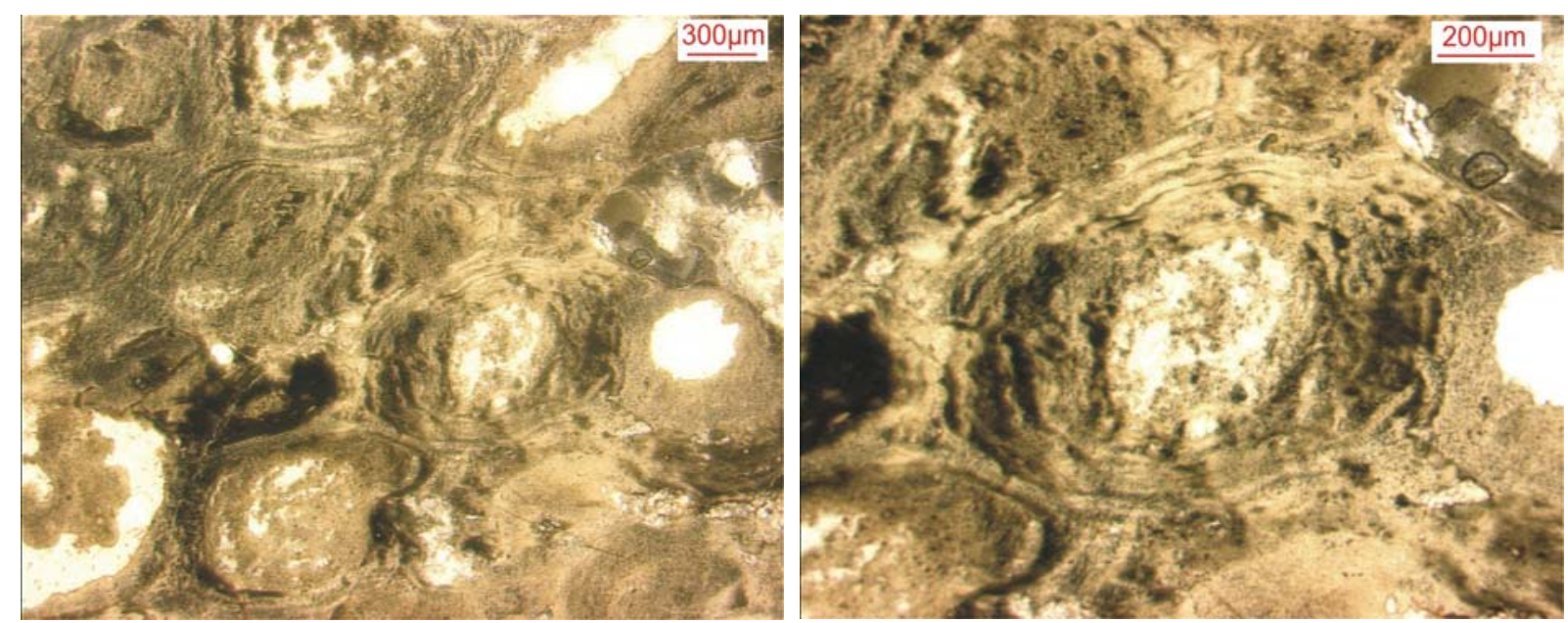

Figura 7.1.29 - Partículas fosfáticas alongadas, à esquerda, e à direita, detalhe da partícula com incipiente laminação finamente crenulada.
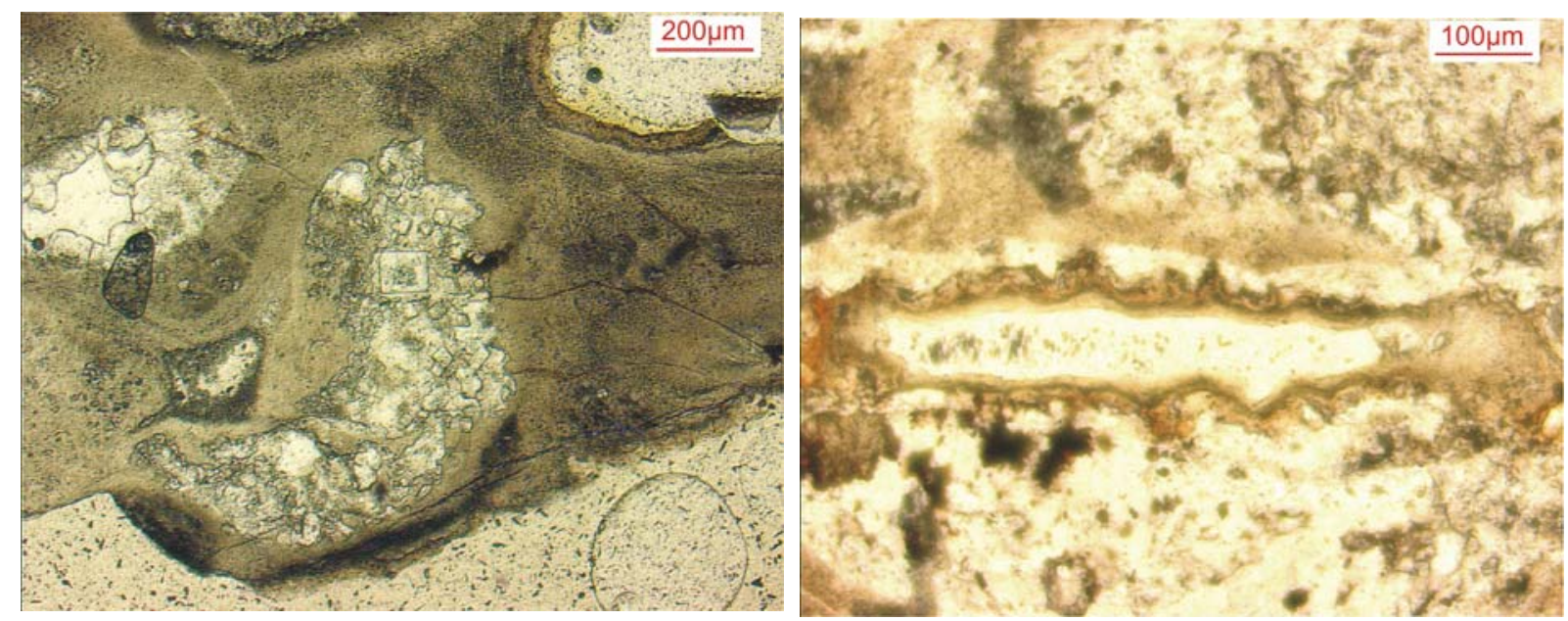

Figura 7.1.30 - Poro originário da dissolução do núcleo do grão, preenchido por apatita euhedrica (à esquerda) porosidade tipo fenestral preenchida por argilo-minerais (à direita).

\subsubsection{Fosfarenito}

A fácies de fosfarenito é composta por grãos de fosfato fino, bem arredondados, com baixa esfericidade, moderadamente selecionado, com granulação variando entre 0,05 a 1,0 mm (Figura 7.1.31). Subordinadamente, encontram-se grãos de quartzo. Os grãos possuem contato bem definido, por vezes realçado por película de material fosfático mais escuro, e o núcleo dissolvido e eventualmente preenchido por apatita acicular (Figura 7.1.32). Da 
mesma forma, o cimento é composto de apatita acicular e também de sílica microcristalina sacaroidal. Há também a presença de cimento carbonático envolvendo alguns grãos. Outras amostras exibem cimento de óxido de ferro (Figura 7.1.33).

Os clastos parecem ser constituídos do fosfalutito, inclusive apresentando as fraturas e evidências de dissolução pretéritas à formação do fosfarenito.

A mineralogia, pelo método de difração de raio-x, é identificada como exclusivamente apatita (Anexo A - Figura 3).
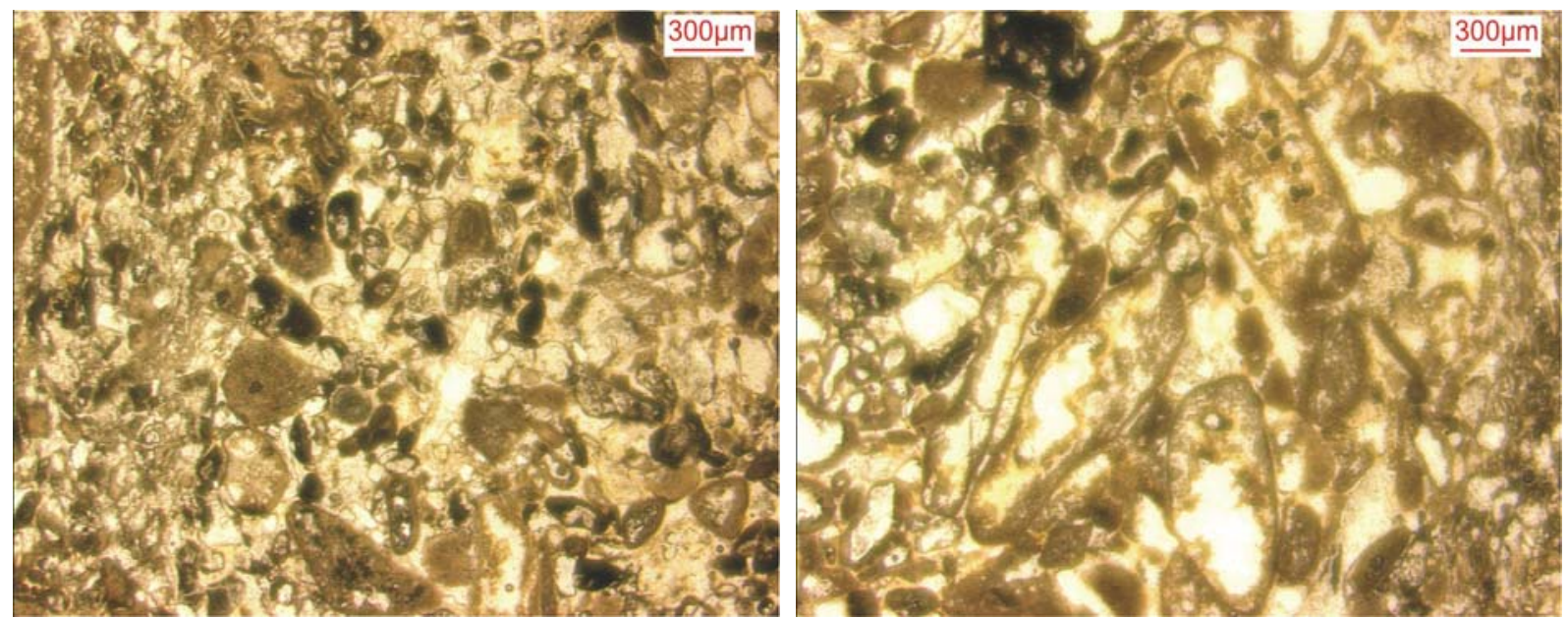

Figura 7.1.31 - Aspecto geral do fosfarenito. Notar a heterogeneidade da granulação.
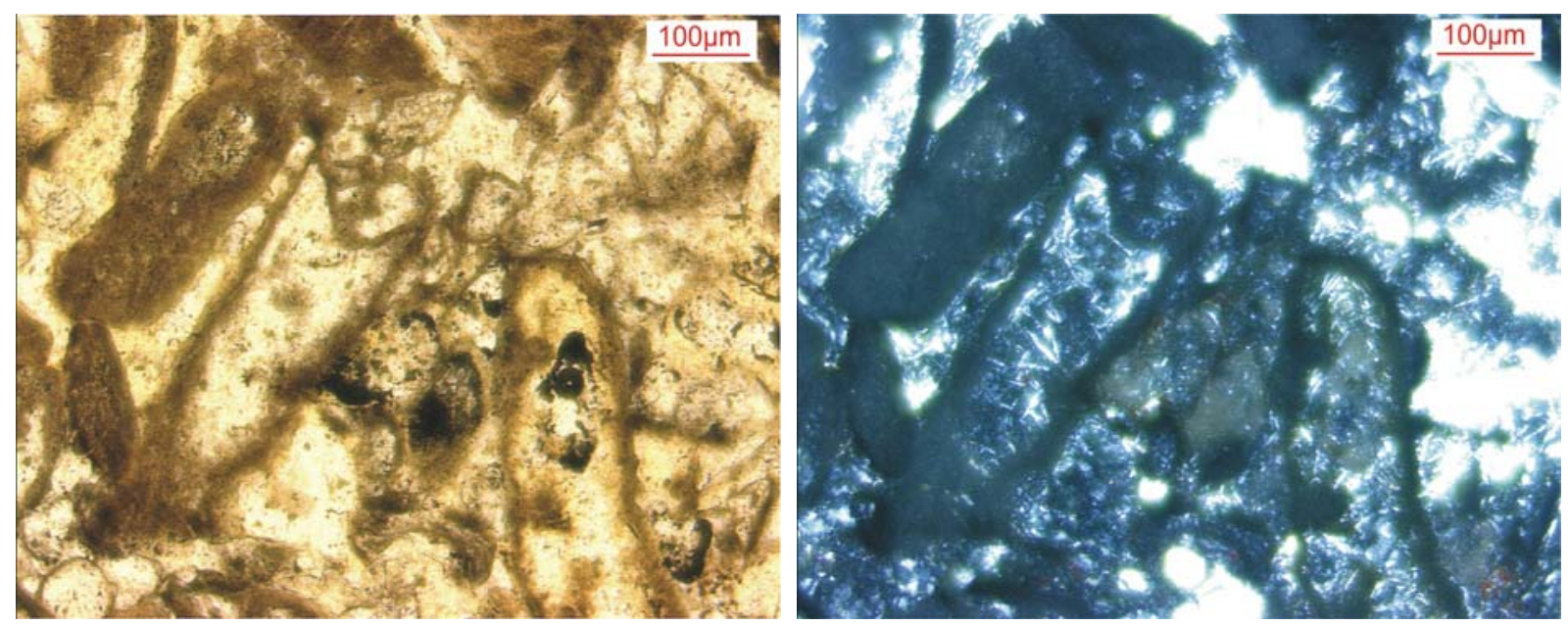

Figura 7.1.32 - Núcleo clástico dissolvido e preenchido por apatita acicular, assim como os interstícios (à esquerda, nicóis paralelos e à direita, nicóis cruzados). 

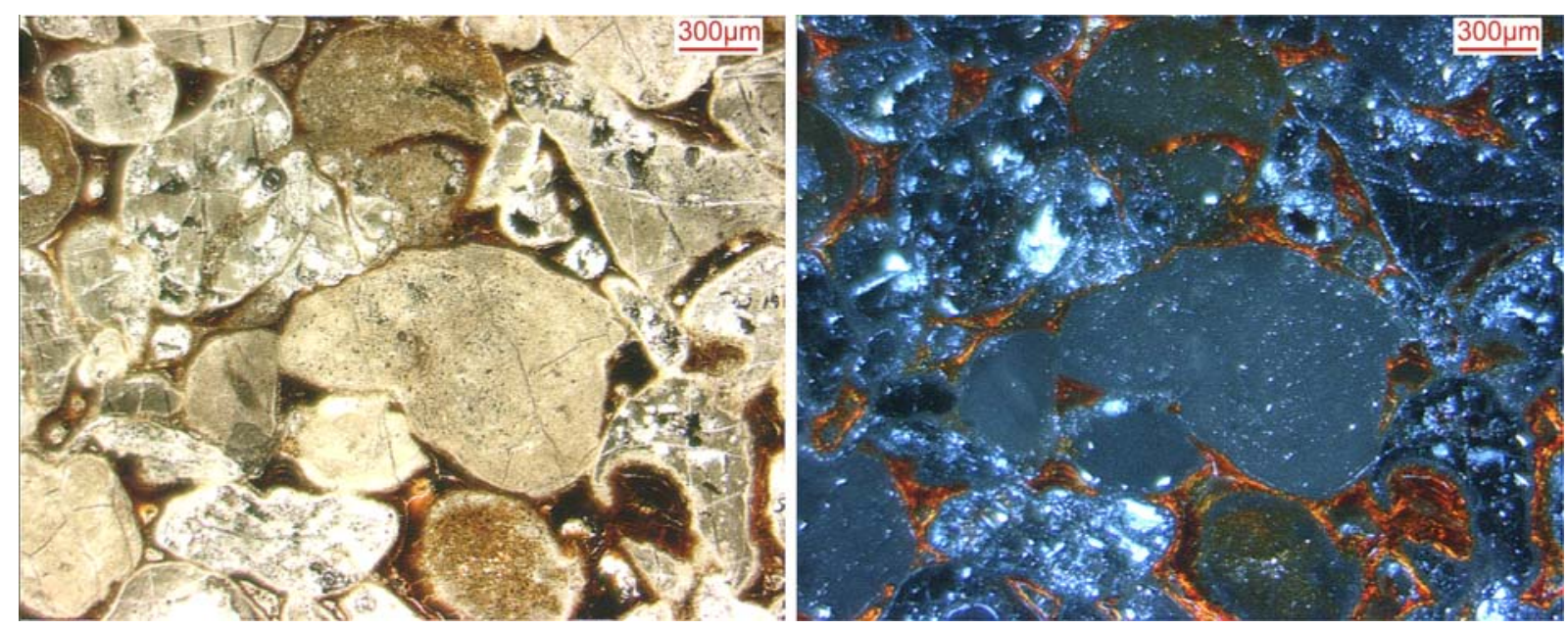

Figura 7.1.33 - Aspecto do fosfarenito, com grãos bem arredondados de fosfato, isótropos a nicóis cruzados (à direita), com cimento de óxido de ferro.

Interpretação: o nível principal de fosforito corresponde ao fosfalutito, em geral com laminação finamente crenulada e porosidade tipo fenestral. Essas características petrográficas sugerem que o fosfalutito correponda a um microbialito. Interpeta-se que a apatita foi formada na eodiagênese, devido à liberação de fósforo a partir da degradação da matéria orgânica preservada nas esteiras microbianas, em ambiente anóxico (SOUDRY; CHAMPETIER, 1983; LUCAS; PRÉVÔT, 1985; RAO et al., 1992; COMPTON et al., 1993). A morfologia dos cristais, observada ao MEV, em arranjo botrioidais, sugerem que a apatita seja bioinduzida.

O fosforito "alongado" aparentemente é formado de grãos revestidos como oncólitos ou pisólitos. A diferença entre estes dois tipos de grãos é que os oncólitos são formados acima da interface sedimento/água enquanto os pisólitos são formados in situ, abaixo desta interface (PERYT, 1983). Para a origem da composição fosfática destes grãos, há duas possibilidades que não podem ser descartadas, e com os estudos realizados neste presente trabalho, não puderam ser diferenciadas: (1) a origem dos grãos é autigênica, como descrita por Pufahl \& Grimm (2003) ou (2) a origem da apatita é secundária, por substituição de carbonato de cálcio previamente formado.

A formação de fosforitos, em geral, está associada a momentos de subida do nível do mar, ou de mar alto, quando são criadas novas mini-bacias, com águas estagnadas que podem ser revolvidas por correntes de ressurgências (SHELDON, 1981; FÖLLMI, 1996; PAPINEAU, 2010). Pufahl \& Grimm (2003), como já citado anteriormente, discutem a possibilidade de grãos revestidos fosfáticos serem correlacionáveis à superfícies condensadas (máxima transgressão). 
Já as fácies de fosfarenito indicam o retrabalhamento dessa superfície, a partir do rebaixamento do nível do mar. A associação com o conglomerado polimítico da Formação Tamengo, estratigraficamente acima do nível fosfático, reforça hipótese de rebaixamento do nível do mar.

\subsubsection{Fácies de Conglomerado Polimítico}

Amostras: FR-25

Descrição: conglomerado polimítico de matriz micrítica dolomítica, com clastos centimétricos a decimétricos do embasamento granítico, dos dolomitos e fosforitos da Formação Bocaina, além de silexito e calcário. Compreende um corpo contínuo ao longo da Rodovia Bonito-Bodoquena, sendo registrado também em Corumbá (Mina Laginha) e em Porto Morrinhos (BOGGIANI, 1998).

Na Fazenda Ressaca, foram observados clastos mal selecionados, de dolomito fino sub-anguloso e fosforito maciço e estratificado sub-arredondado de tamanho centimétrico, em matriz dolomítica. Foi descrita neste trabalho também na Mina Laginha em Corumbá, MS, na qual foi registrada a presença de clastos sub-arredondados de fosforito preto milimétricos a centimétricos (Figura 7.1.34).

Em seção delgada (Figura 7.1.35) apresenta matriz micrítica com alguns cristais dispersos de dolomita espática de até $0,1 \mathrm{~mm}$ de comprimento. Apresenta clastos arredondados de quartzo monocristalino, variando de 0,2 a $5 \mathrm{~mm}$ de diâmetro, de quartzo policristalino de textura sacaroidal com diâmetro de 0,7 a superior a $1 \mathrm{~mm}$, de dolomito oolítico anguloso de até $4 \mathrm{~mm}$ de comprimento, clastos arredondados e com baixa esfericidade de material fosfático fino e fraturado e clastos angulosos a sub-arredondados de fosforito constituído por pelóides.

Interpretação: A fácies de Conglomerado Polimítico tem sua gênese associada com o rebaixamento eustático com retrabalhamento e deposição dos clastos oriundos da Formação Bocaina na borda de plataforma (BOGGIANI, 1998). 


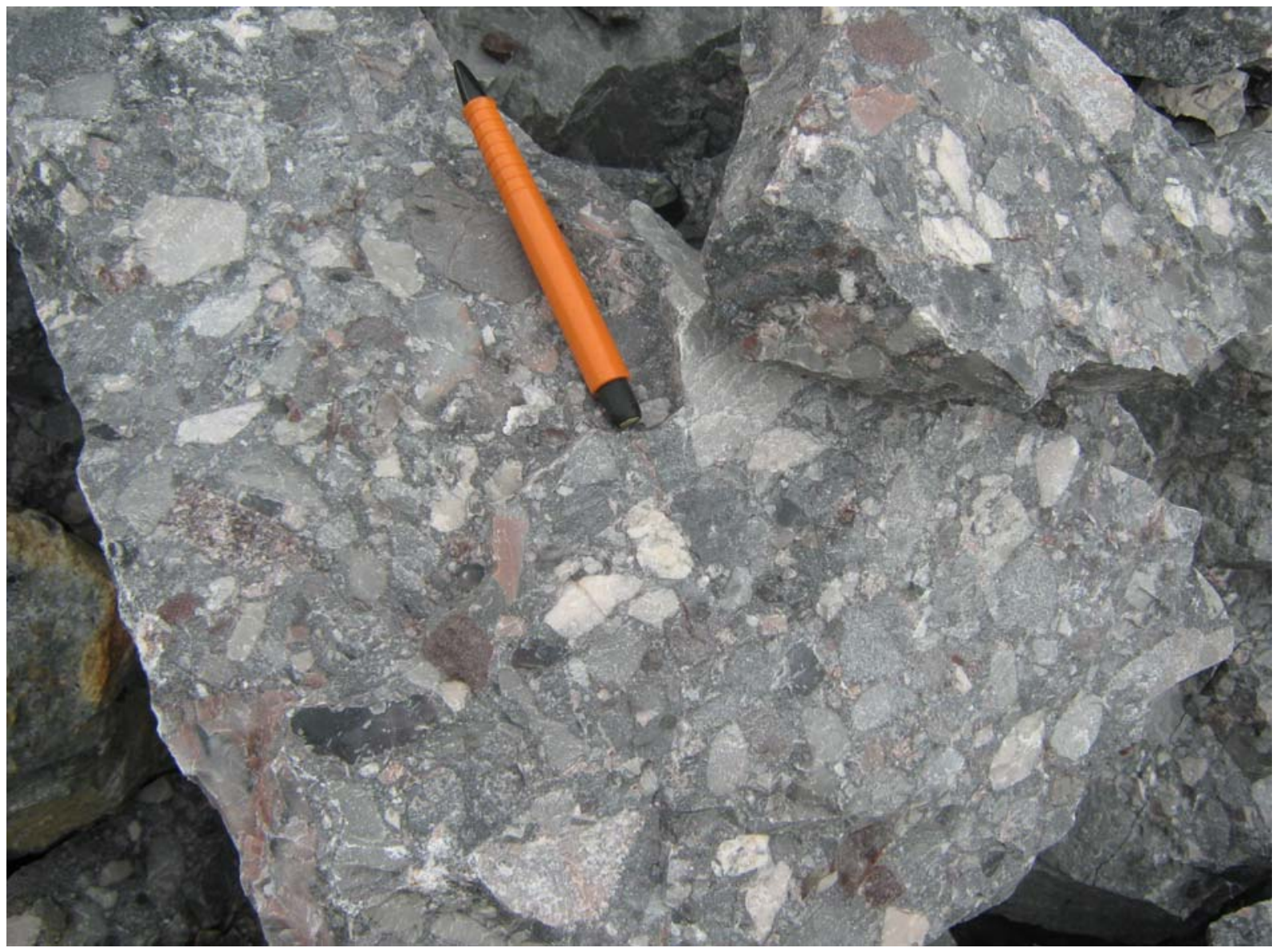

Figura 7.1.34 - Aspecto macroscópico do conglomerado polimítico da base da Formação Tamengo (Mina Laginha, Corumbá). Notar a heterogeneidade litológica dos clastos.
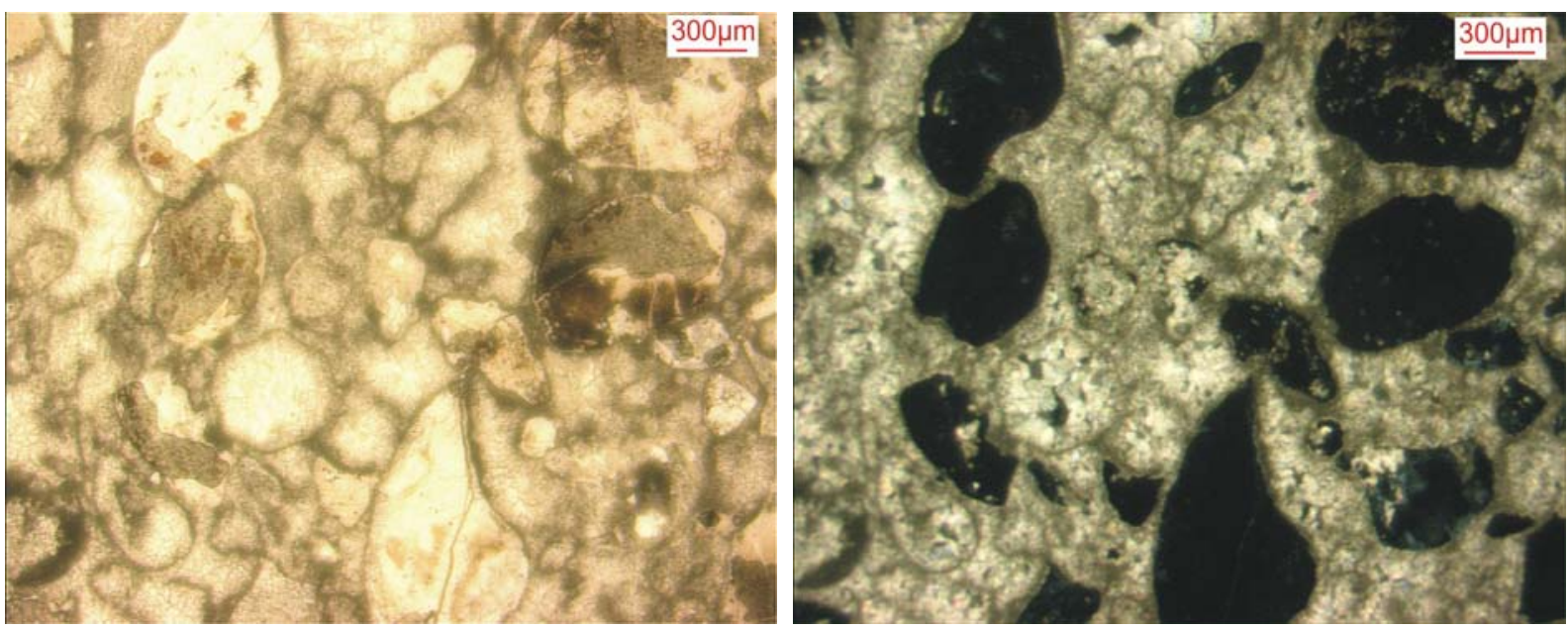

Figura 7.1.35 - Aspecto do conglomerado polimítico em seção delgada. Observar clastos de fosforito isótropos sob nicóis cruzados em matriz dolomítica recristalizada (direita). 


\subsection{Fácies Sedimentares do Morro do Bugio}

O Morro do Bugio está localizado na cidade de Ladário, próximo a Corumbá. Tratase de uma mina de calcário desativada, onde se pode observar o topo da Formação Bocaina e base da Formação Tamengo.

Nesta seção, pôde-se individualizar fácies de grainstone com grande quantidade de oóides, muito bem preservados devido à silicificação, e também grainstones com menor quantidade de oóides. No topo da seção, observa-se brechas intraformacionais com estruturas do tipo tepee.

\subsubsection{Fácies de Grainstone Oolítico Silicificado}

Descrição: grainstone composto por oóides bem arredondados de até 1,5 $\mathrm{mm}$ de diâmetro, com laminação concêntrica bem definida, silicificados (Figura 7.2.1 a 7.2.6). Alguns apresentam formas ovais ou curvas, porém preservando a laminação contínua e uniforme (Figura 7.2.2). Já outros exemplares possuem a laminação truncada (Figura 7.2.3). Algumas amostras ainda exibem o dolomito original em algumas lâminas dos oóides (Figura 7.2.4).

Em algumas seções delgadas, pôde-se observar a presença de grãos de areia quartzosa bem arredondados (Figura 7.2.5). Os grãos revestidos se tocam, os interstícios estão preenchido por sílica sacaroidal.

Interpretação: a presença de oóides indica ambiente de águas e agitadas. Os grãos de quartzo bem arredondado em meio aos oóides sugerem também um ambiente de alta energia, como discutido para a fácies de Grainstone oolítico inferior, da Fazenda Ressaca. A laminação truncada indica momentos de movimentação e momentos em que o grão permaneceria parado, durante sua formação.

Provavelmente esses oóides foram rapidamente cimentados, devido a boa preservação das estruturas sedimentares primárias não afetadas por compactação. A mineralogia dos oóides bem como do cimento não é possível de identificar, já que a maior parte da rocha está silicificada. A sílica, aparentemente, substituí o carbonato que previamente constituía os oóides, reliquiar em alguns grãos revestidos (Figura 7.2.4), provavelmente em diagênese tardia, pois se observa veios de sílica cortando os grãos revestidos (Figura 7.2.6). 

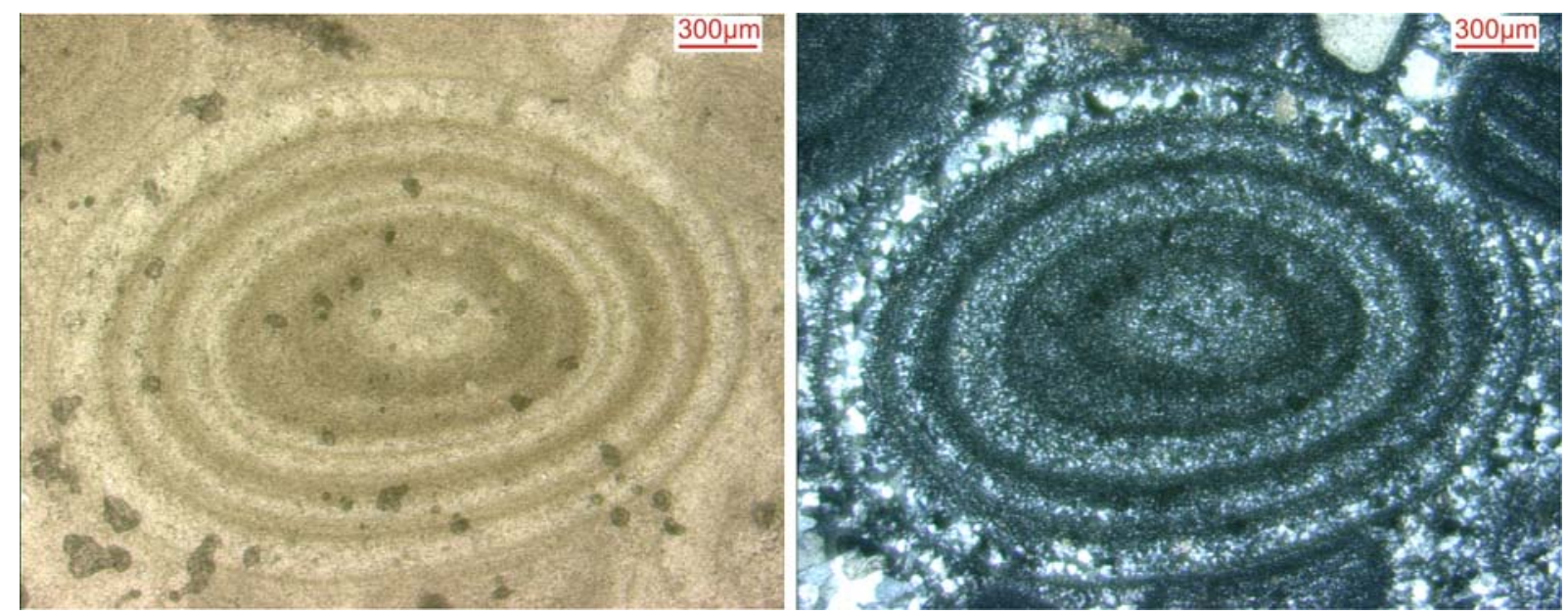

Figura 7.2.1 - Oóides da fácies de grainstone oolítico silicificado. Observar a laminação concêntrica e a total silicificação. À esquerda, nicóis paralelos, e à direita, nicóis cruzados.
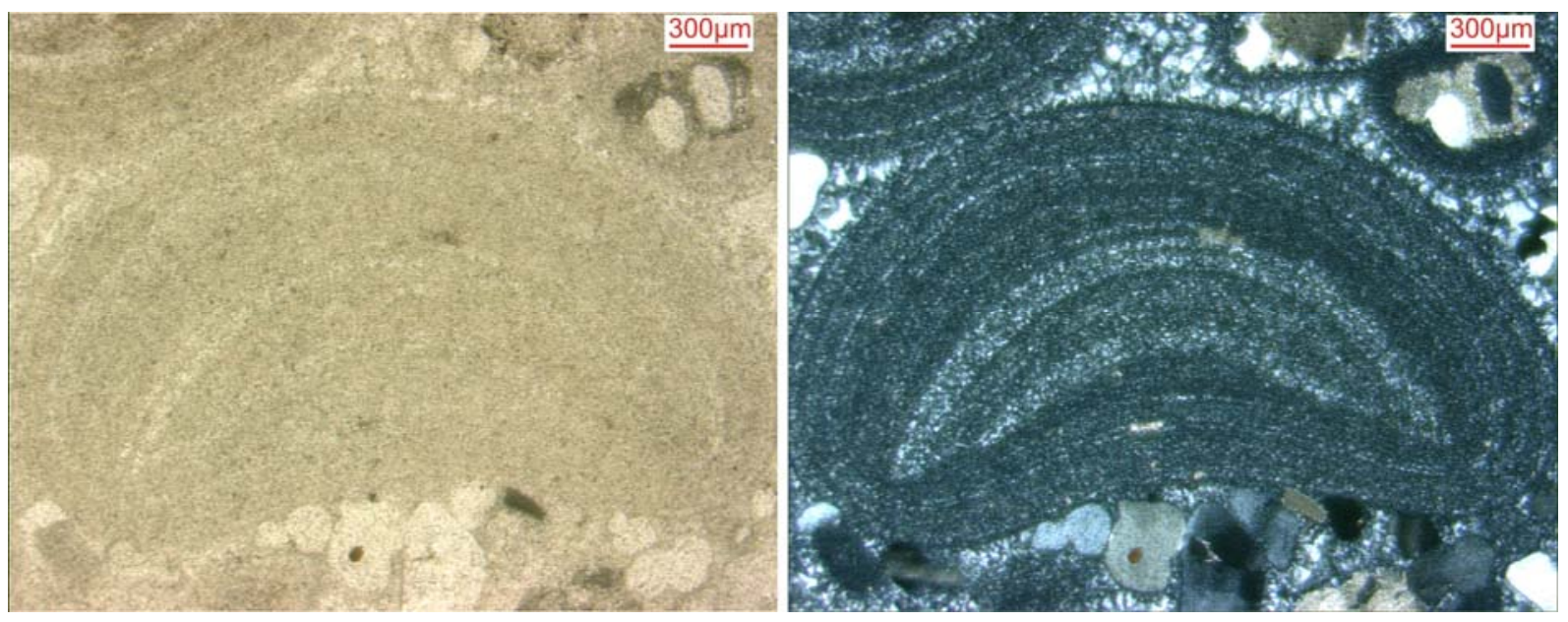

Figura 7.2.2 - Variedade de grãos revestidos da fácies de grainstone oolítico silicificado. Observar a laminação concêntrica porém o formato curvilíneo do grão e a total silicificação. À esquerda, nicóis paralelos, e à direita, nicóis cruzados.

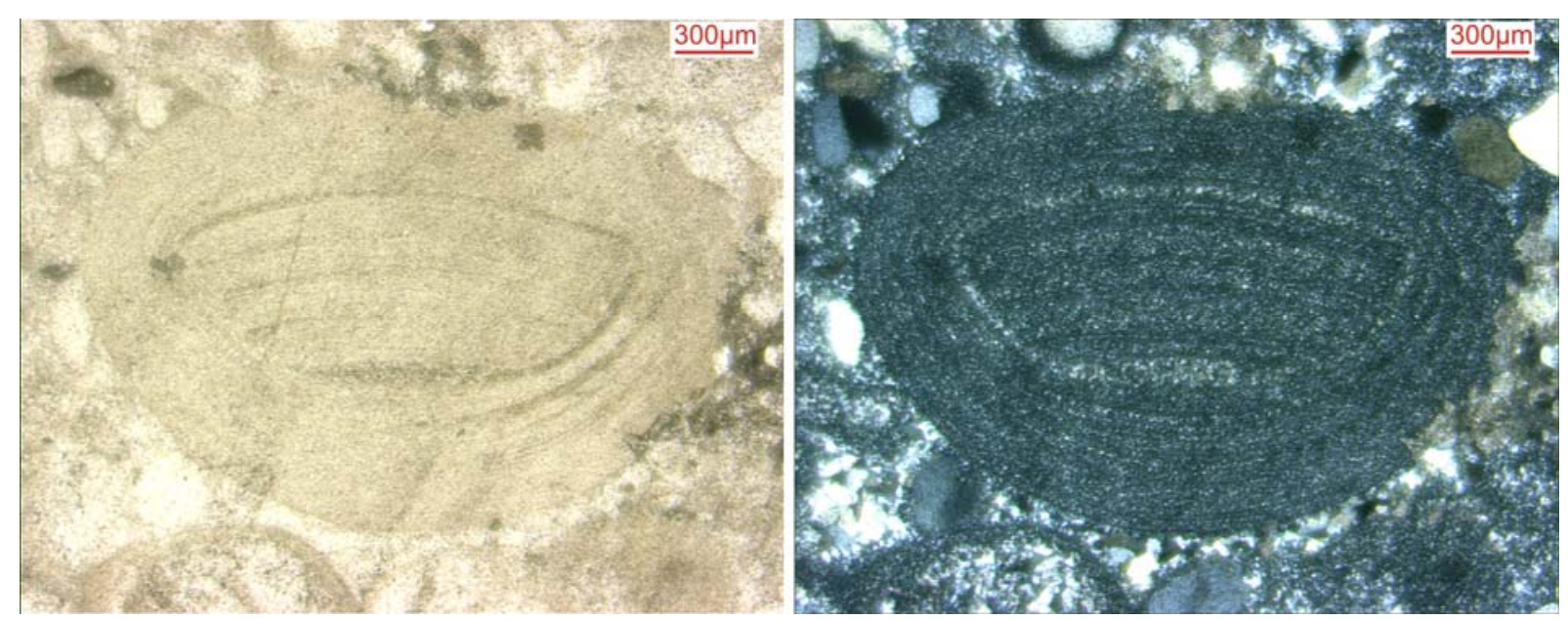

Figura 7.2.3 - Grão revestido com laminação truncada. A porção central indica que o grão estava parado durante sua formação, enquanto a porção externa, cuja laminação é contínua, demonstra que houve movimentação durante esta fase de desenvolvimento do grão revestido. À esquerda, nicóis paralelos, e à direita, nicóis cruzados. 

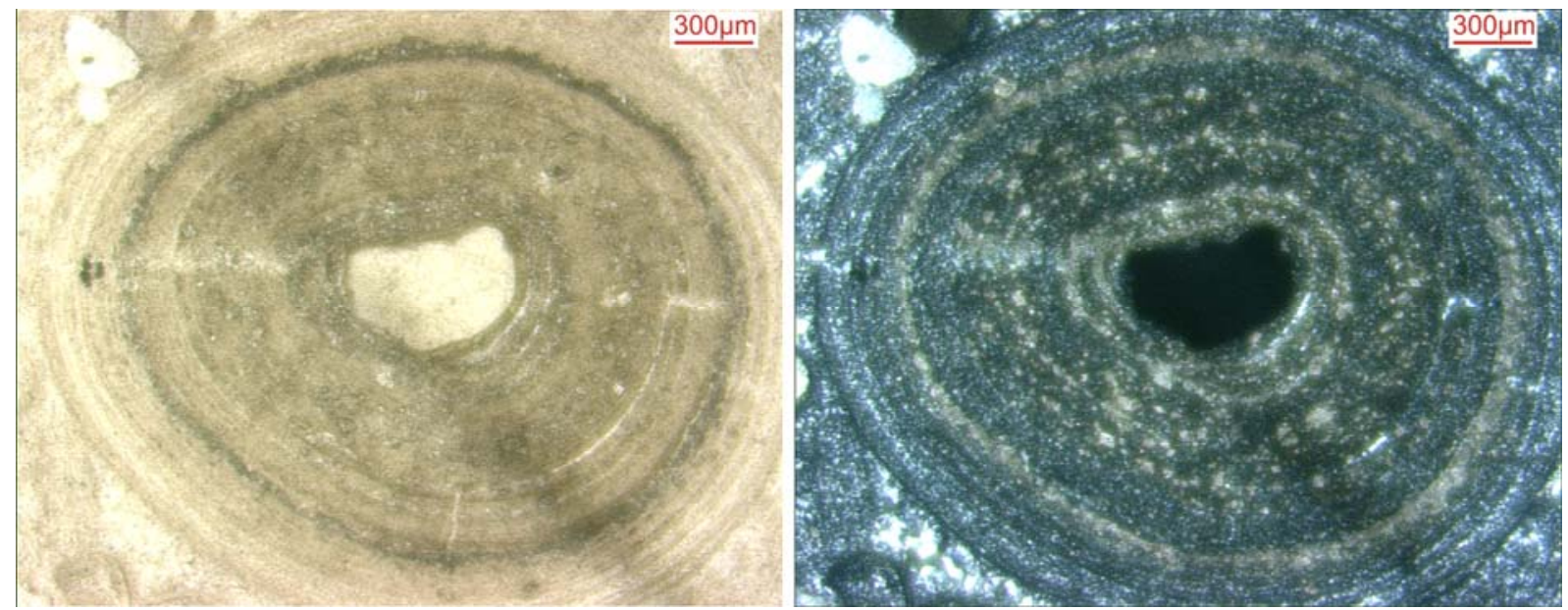

Figura 7.2.4 - Resquício de dolomito em oóide silicificado da fácies grainstone oolítico silicificado. À esquerda, nicóis paralelos, e à direita, nicóis cruzados.
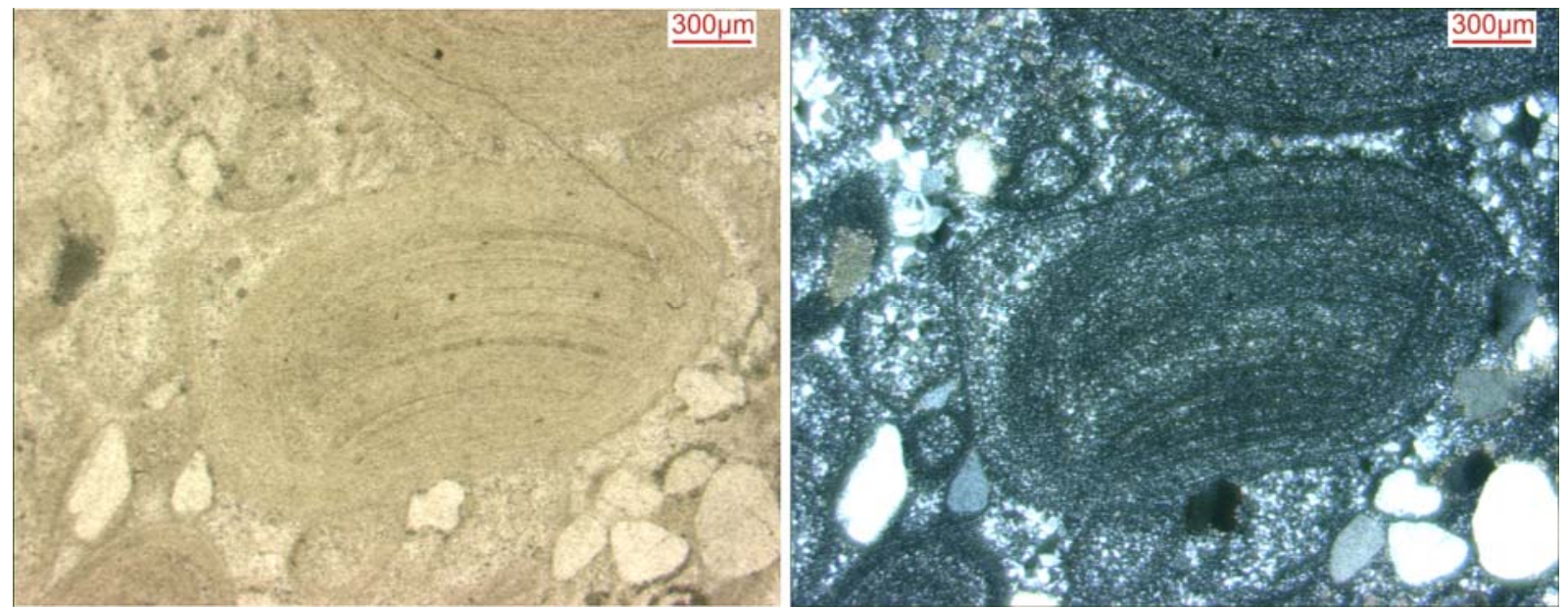

Figura 7.2.5 - Grãos de quartzo junto de oóides da fácies de grainstone oolítico silicificado. À esquerda, nicóis paralelos, e à direita, nicóis cruzados.
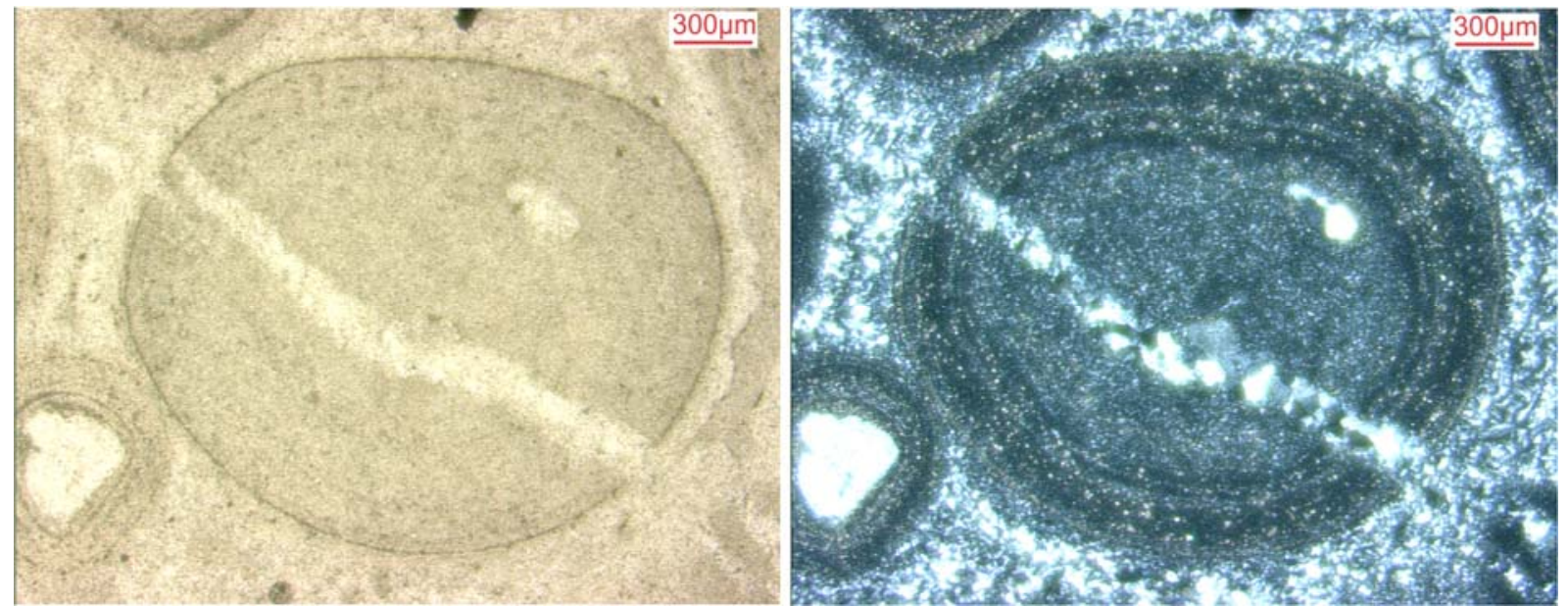

Figura 7.2.6 - Veio de sílica cortando o oóide, indicando que corresponde a um processo posterior a formação e cimentação dos grãos revestidos. 


\subsubsection{Fácies de Grainstone com oóides}

Descrição: grainstone composto por oóides sub-milimétricos dispersos em matriz dolomítica, diferentemente da fácies descrita anteriormente, na qual a quantidade de oóides é muito maior. Possui níveis intercalados de brechas intraformacionais, com clastos angulosos, centimétricos do próprio grainstone com oóides em matriz dolomítica fina (Figura 7.2.7).

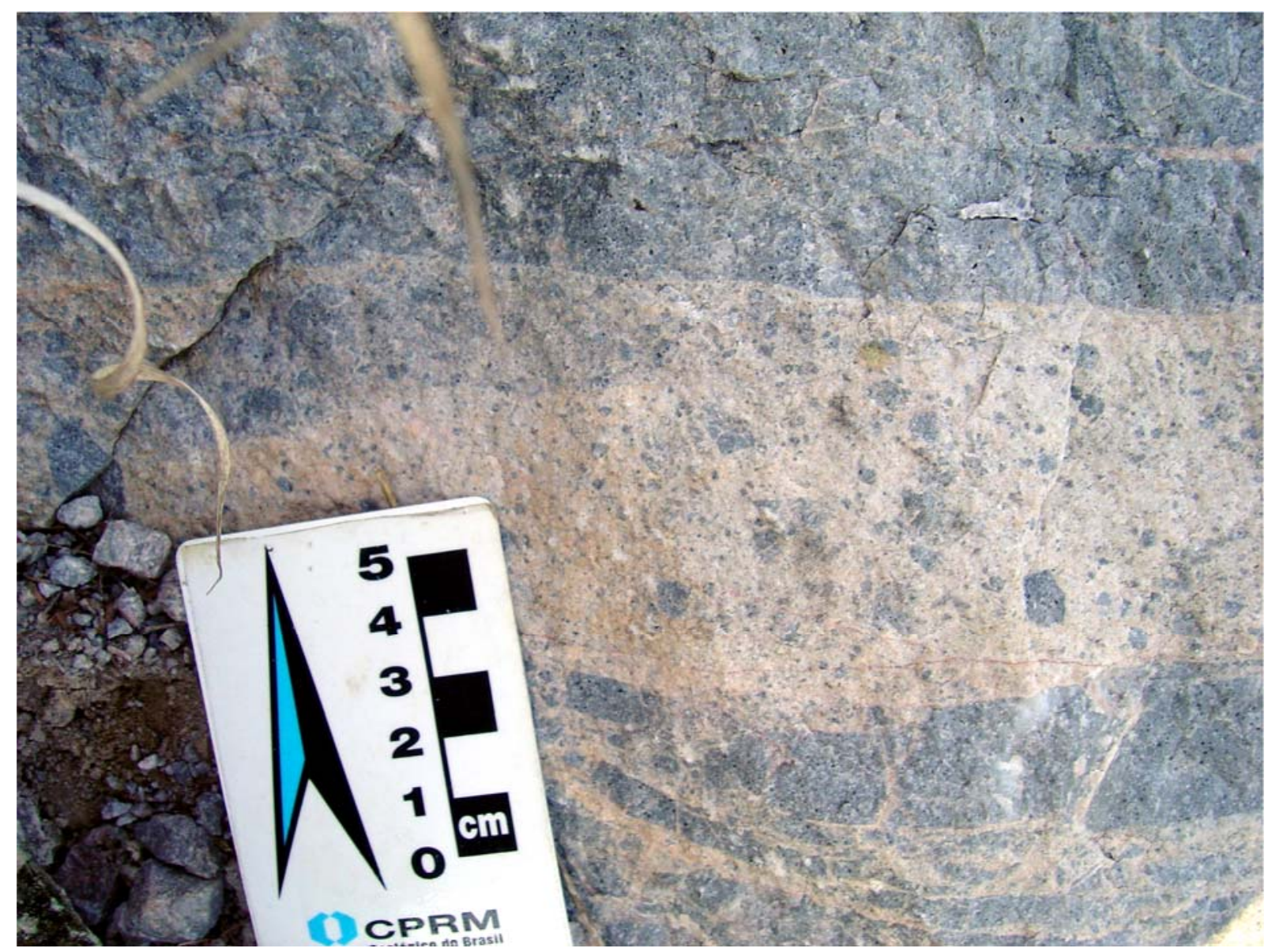

Figura 7.2.7 - Nível de brecha intraformacional intercalado ao grainstone com oóides.

Interpretação: a presença de oóides indica águas rasas e agitadas para a formação da fácies de grainstone com oóide. A ausência de seções delgadas dessa fácies não permite maiores interpretações sobre a fácies. A intercalação com níveis de brechas intraformacionais indica rápida exposição subaérea destes sedimentos que são rompidos e retrabalhados com a subida novamente do nível do mar. 


\subsubsection{Fácies de Rudstone Intraformacional}

Descrição: brechas com clastos de mudstone dolomítico angulosos, tabulares, tanto milimétricos, como podendo atingir até mais de $30 \mathrm{~cm}$ de comprimento, dispostos em matriz dolomítica fina (Figura 7.2.8). Por vezes, os clastos apresentam-se imbricados e arqueados em pseudo-anticlinais, semelhantes a estruturas tepee. Observa-se também a presença de grãos de areia muito fina e bem arredondados, compostos de quartzo, dispersos em matriz micrítica (Figura 7.2.9).

Estas brechas afloram também em outras localidades, como na estrada municipal MS-243, na porção NE da Serra da Bodoquena.

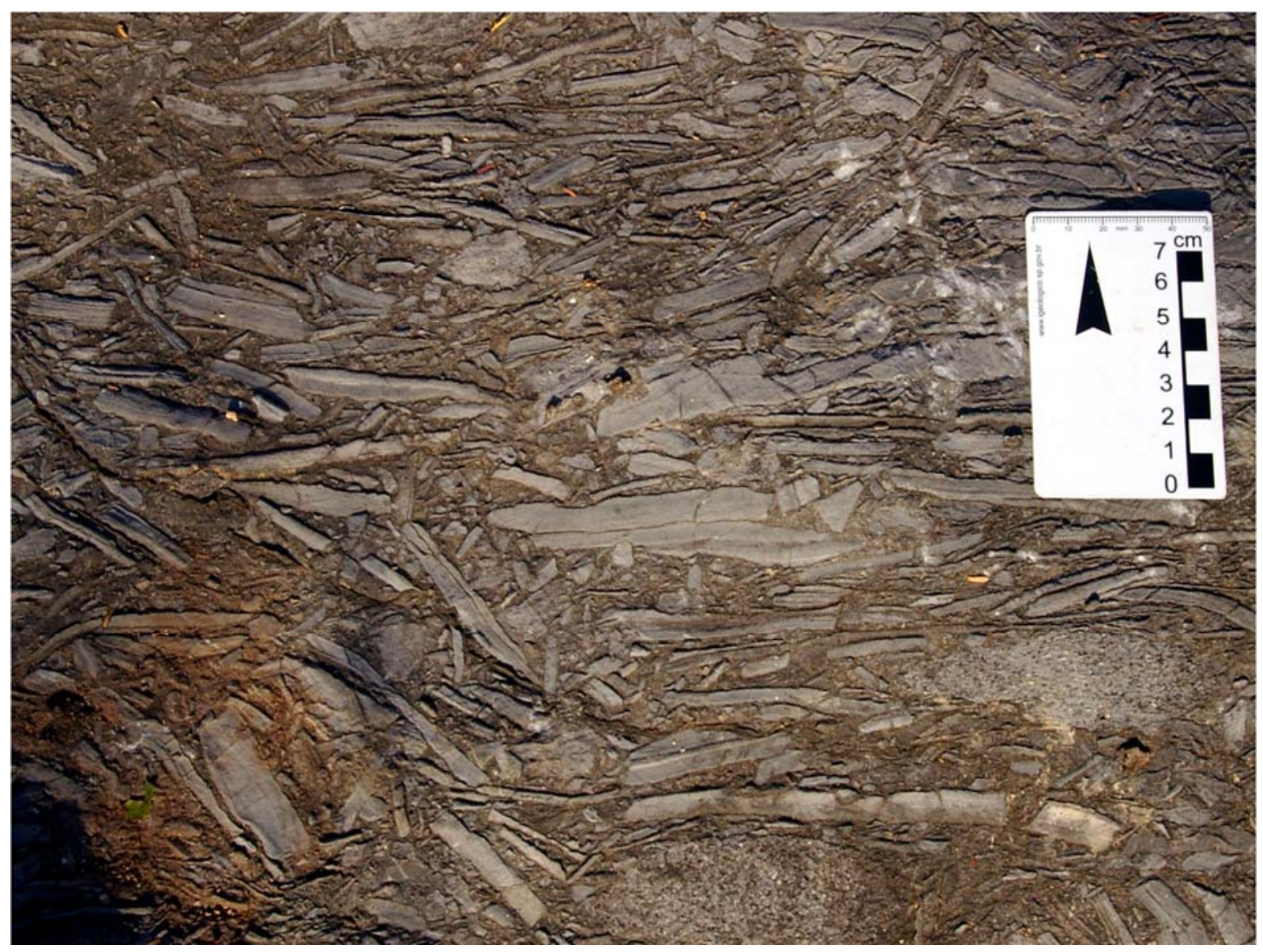

Figura 7.2.8 - Aspecto macroscópico da brecha intraformacional. Observar os clastos centimétricos a decimétricos, tabulares, angulosos, rompidos e arqueados de dolomito em matriz dolomítica. Interpreta-se que esta estrutura seja gerada por processos repetitivos de contração e expansão da superfície deposicional, durante a alternância de períodos de exposição subaérea e presença de água, com cristalização e dissolução de minerais carbonáticos e/ou evaporíticos (estrutura tepee). 

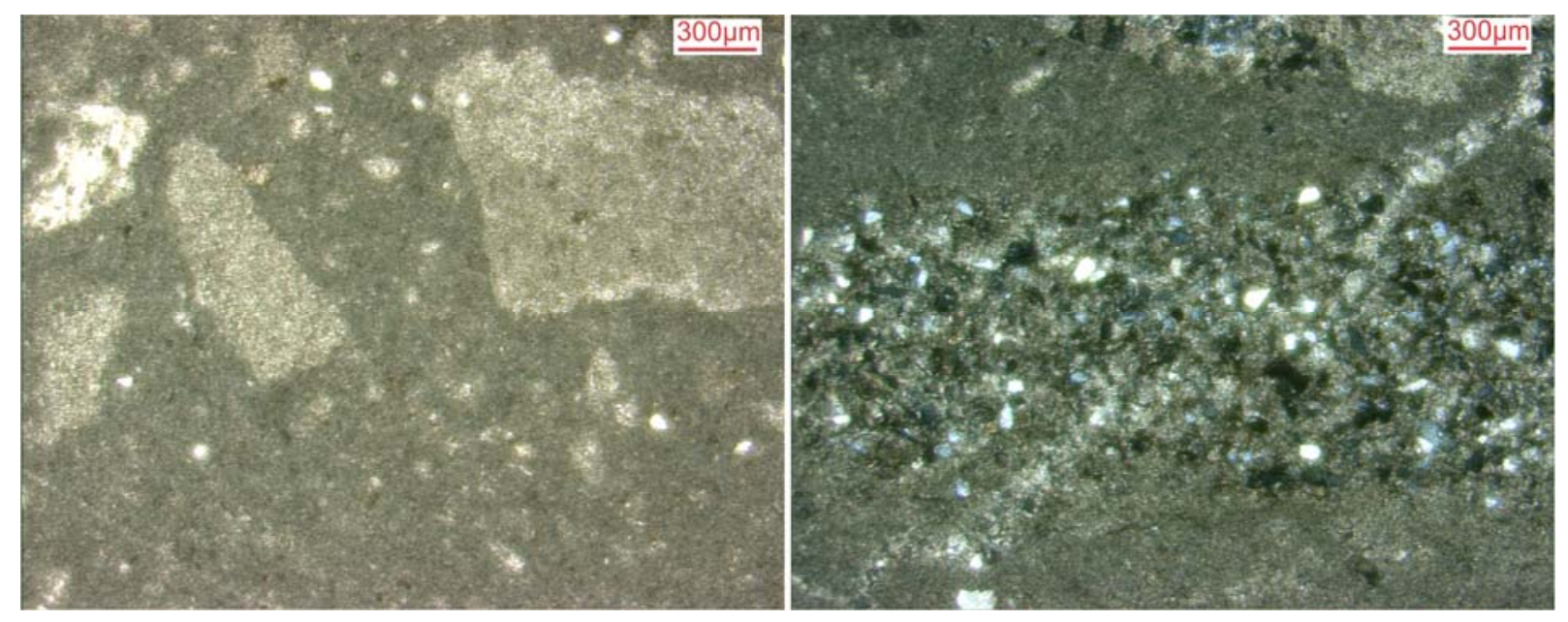

Figura 7.2.9 - Aspecto microscópico da brecha intraformacional. À esquerda, observa-se clastos de mudstone e grãos detríticos de quartzo também dispersos na matriz dolomítica (nicóis paralelos). À direita, observa-se elevada concentração de grãos de quartzo detríticos em matriz dolomítica (nicóis cruzados).

Interpretação: O termo tepee refere-se a uma complexa estrutura de fragmentos tabulares intraclásticos (megapolígonos), geralmente de material carbonático que podem estar imbricados, assemelhando-se a tendas de índios americanos, de onde se origina o nome da estrutura. Em geral, formam pseudo-anticlinais frutos da expansão da superfície sedimentar causada por processos repetitivos e contínuos de dessecação e contração termal, durante períodos áridos, gerando pequenas fraturas que são alargadas durante os períodos úmidos, seguidas de cristalização de carbonato de cálcio e outros minerais, em geral evaporíticos, que podem aumentar as fraturas e também cimentá-las (ASSERETO; KENDALL, 1977).

O tepee pode caracterizar desde uma crosta subaérea cimentada, exibindo estruturas de compressão e expansão, até um sedimento completamente rompido e brechado, com numerosas fraturas e cavidades que podem ser preenchidas por diversas fases de cimentos marinhos e de água doce.

Desenvolvem-se em sedimentos lacustrinos ou de supramarés, tanto submarinos como subaéreos, pela alternância de condições freáticas e vadosas em intervalo de tempo de dias ou anos, bem como em perfis de solos (calcretes) (KENDALL; WARREN, 1987).

Tepees são aplicados na reconstrução geológica por serem evidências de exposição subaérea em clima árido a semi-árido. Economicamente, tepees são importantes por possuírem boa porosidade para reservatórios de petróleo além de funcionarem com sítio de mineralização de minérios metálicos e não-metálicos (ASSERETO; KENDALL, 1977).

Para a Formação Bocaina, considerando o contexto das outras fácies sedimentares da Fazenda Ressaca, que já possuem indicativos de clima quente e árido, como por exemplo os pseudomorfos de cristais de gipso, interpreta-se que essas brechas 
representem estruturas tepee, e tenham a origem relacionada à exposição subaérea, ressecamento e rompimento da camada de mudstone original, em clima árido. A presença de grãos de quartzo indica a entrada de sedimentos terrígenos.

\subsection{Estromatólitos de Porto Morrinhos}

Os estromatólitos de Porto Morrinhos afloram na margem oeste do Rio Paraguai, cuja referência é a ponte da BR-262 que cruza o rio nesta localidade.

$\mathrm{Na}$ base do afloramento, observa-se a predominância de estromatólitos dômicos, centimétricos a métricos, de laminação convexa lisa, que lateralmente variam para o tipo esteira, e verticalmente para estromatólitos colunares que podem atingir até $2 \mathrm{~m}$ de altura (Figura 7.3.1). Lateralmente, estão associados à brechas intraformacionais compostas de clastos centimétricos à métricos, inclusive dos estromatólitos (Figura 7.3.2).

Em parte, os estromatólitos encontram-se fosfatizados, e observa-se a presença de níveis centimétricos contendo clastos sub-arredondados de material fosfático preto (Figura 7.3.2).

Acima dos estromatólitos, há um nível de mudstone bege claro laminado, de aproximadamente $50 \mathrm{~cm}$ de espessura, sobreposto por camada de folhelho preto, seguidos novamente por mudstones dolomíticos bege claro. A figura 7.3.3 é uma representação esquemática do afloramento com seus principais elementos sedimentológicos.

Microscopicamente, os dolomitos de Porto Morrinhos são formados por cristais com morfologia ovalada de 10 a $30 \mu \mathrm{m}$ de comprimento. Observa-se cimento de óxido de ferro relacionado às fraturas da rocha (Figura 7.3.4).
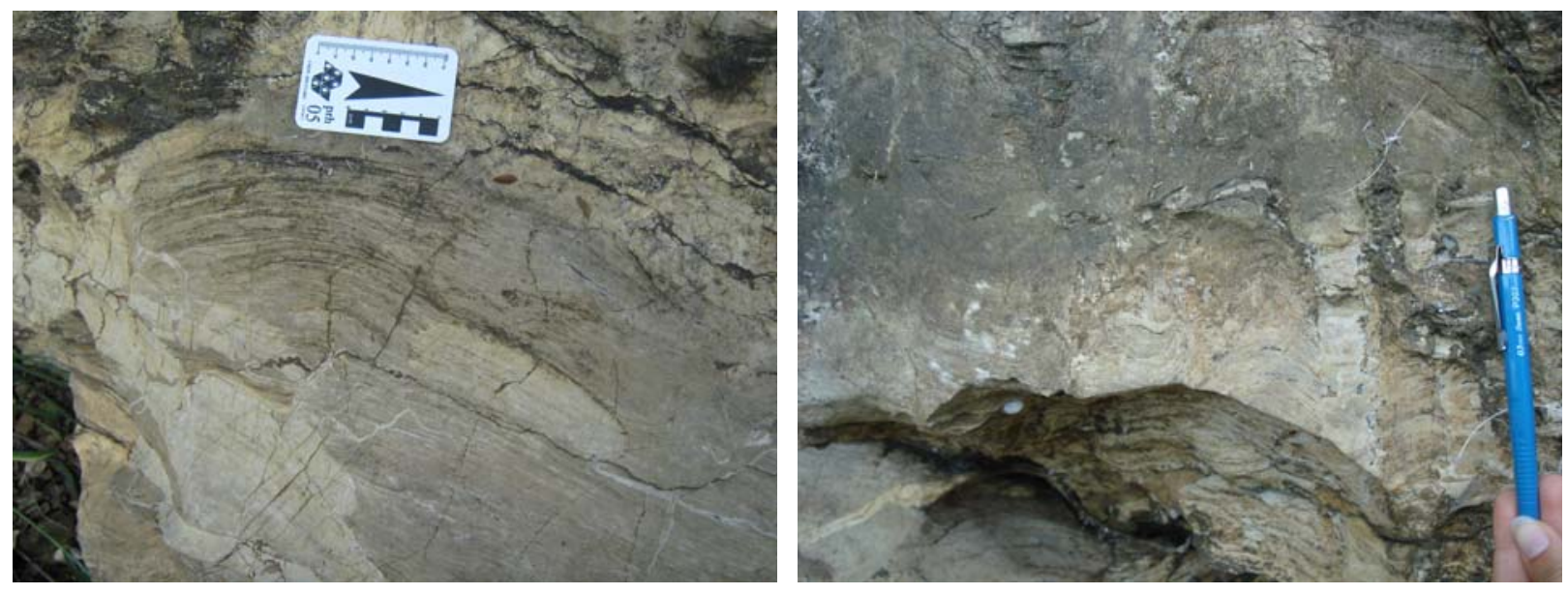

Figura 7.3.1 - Detalhe dos estromatólitos de Porto Morrinhos. À esquerda, etromatólito dômico e à direita detalhe da laminação convexa e lisa e do espaço intercolunar. 

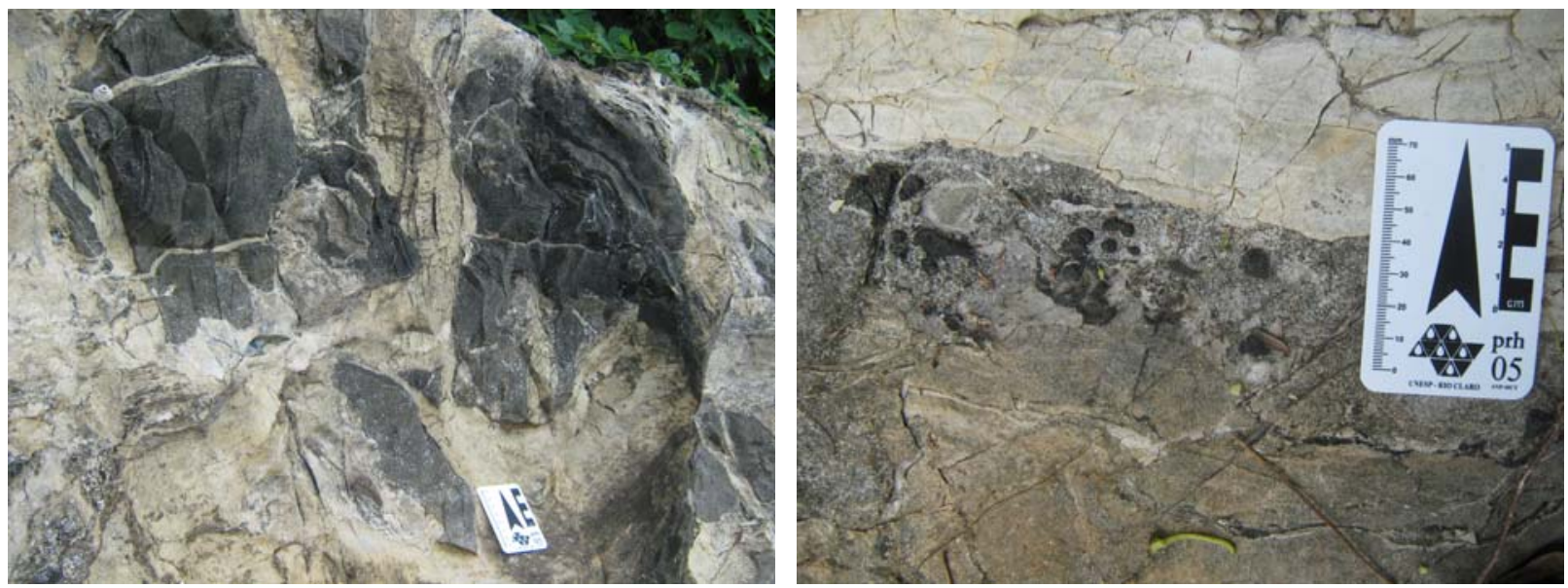

Figura 7.3.2 - À esquerda, brecha intraformacional e à direita, níveis centimétricos contendo partículas fosfáticas pretas sub-arredondadas.

\section{SSW}

NNE

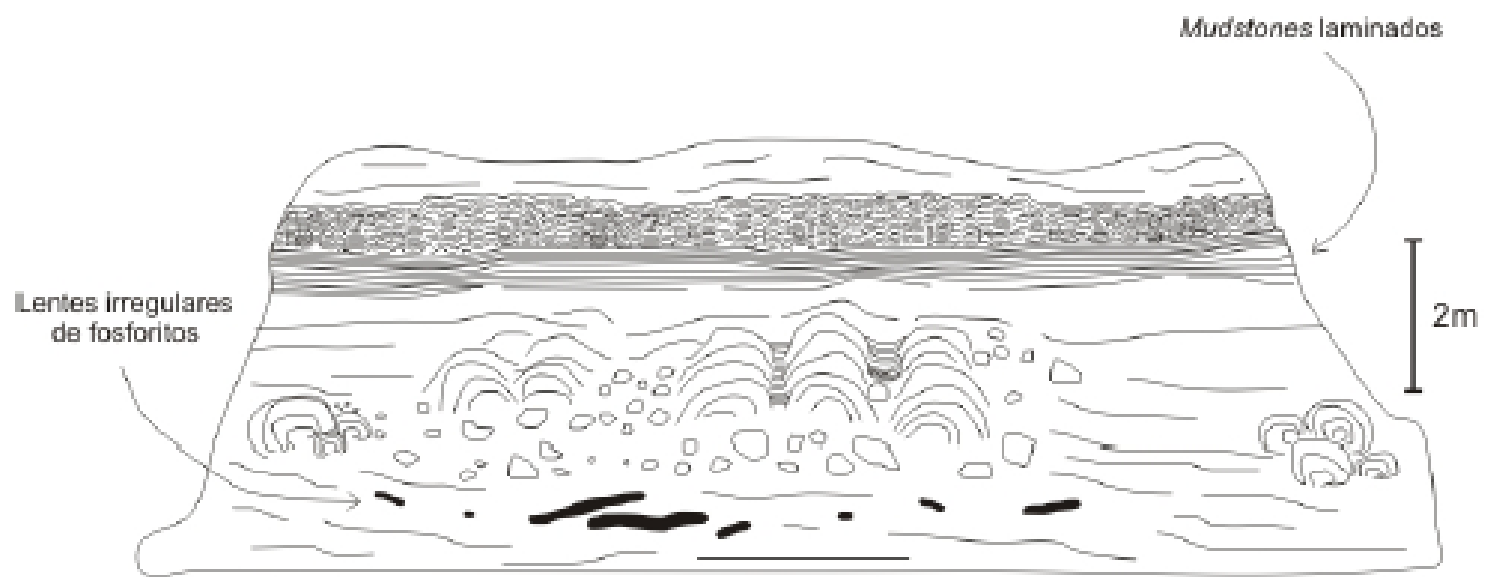

Figura 7.3.3 - Desenho esquemático do afloramento de Porto Morrinhos, ilustrando os estromatólitos colunares e dômicos, bem como os níveis com clastos de fosforito e as brechas intraformacionais. No topo, o autor ilustra a camada pelítica preta, sobreposta por mudstones (FREITAS, 2010).

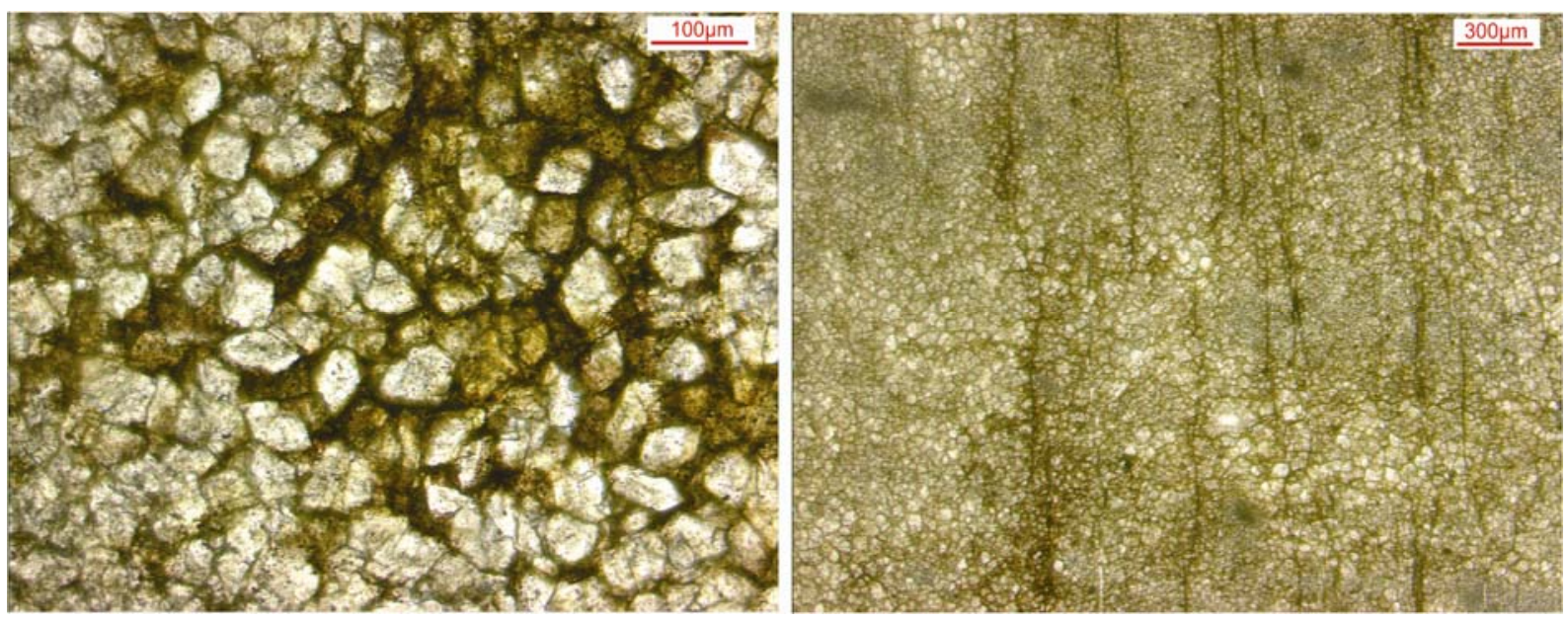

Figura 7.3.4 - Dolomitos de Porto Morrinhos visto ao microscópio petrográfico. À esquerda, notar a morfologia ovalada dos cristais e a presença de cimento de óxido de ferro. À direita, observar a grande quantidade de fraturas tardias preenchidas com cimento de óxido de ferro (nicóis paralelos). 
Interpretação: os estromatólitos de Porto Morrinhos foram interpretados por Boggiani (1998) como formados em ambiente de intermaré a inframaré, relacionados à ação de correntes e o nível pelítico foi interpretado como superfície de inundação máxima. Para o referido autor, a mudança dos tipos morfológicos de estromatólitos reflete mudanças nas condições ambientais, provavelmente relacionadas à subida do nível do mar.

Freitas (2010) interpreta os estromatólitos de Porto Morrinhos como a expressão de um recife e atribui as mudanças morfológicas à variações laterais da estrutura do recife bem como da espessura da lâmina d'água. As brechas intraformacionais relacionadas aos estromatólitos são interpretadas como produto de fluxo gravitacional na região do forereef.

A composição dolomítica para estas rochas, como discutido anteriormente, podem ser: (1) primária, e a dolomita formou-se a partir da bioindução em sedimentos ricos em matéria orgânica e (2) secundária, na qual a dolomita representa a substituição do carbonato de cálcio pré-existente. Acredita-se que a segunda hipótese seja mais coerente, uma vez que os cristais de dolomita não são compatíveis a cristais bioinduzido (menores que $1 \mu \mathrm{m}$ ), apesar da morfologia ovalada. No entanto, com base em apenas uma lâmina petrográfica não é possível definir a origem do mineral.

\section{GEOQUÍMICA DA FORMAÇÃO BOCAINA}

\subsection{Geoquímica elementar dos dolomitos}

Foram analisadas 14 amostras de dolomitos da Fazenda Ressaca, pelo método de Fluorescência de raios-X (FR-X). Todas as amostras são da Formação Bocaina e compreendem grainstones e mudstones além de brechas intraformacionais, com exceção do conglomerado polimítico da base da Formação Tamengo. O procedimento analítico esta detalhado no capítulo 4. Métodos. Os resultados obtidos estão apresentados na tabela 8.1.1.

Os dados obtidos são confiáveis, pois as análises totalizam valores próximos a $100 \%$ (máximo 100,82\% e mínimo 99,04\%). As análises das duplicatas apresentam-se muito semelhante, o que é um bom indicativo da qualidade das análises, assim como o padrão analisado também apresenta valores muito próximos aos recomendados pelo certificado. 
Tabela 8.1.1 - Análise química de rocha total por FR-X para os dolomitos da Fazenda Ressaca.

\begin{tabular}{|c|c|c|c|c|c|c|c|c|}
\hline Amostra & FR - 01 & FR - 03 & FR - 05 & FR - 08 & FR & 09 & FR - 10 & FR - 13 \\
\hline$\% \mathrm{SiO}_{2}$ & $<0.03$ & $<0.03$ & $<0.03$ & $<0.03$ & $<0.03$ & $<0.03$ & 14,67 & $<0.03$ \\
\hline$\% \mathrm{Al}_{2} \mathrm{O}_{3}$ & $<0.01$ & $<0.01$ & $<0.01$ & $<0.01$ & $<0.01$ & $<0.01$ & $<0.01$ & $<0.01$ \\
\hline$\% \mathrm{MnO}$ & $<0.002$ & 0,002 & 0,004 & 0,003 & 0,003 & 0,002 & 0,003 & 0,006 \\
\hline$\% \mathrm{MgO}$ & 19,22 & 19,29 & 19,84 & 21,57 & 20,41 & 20,47 & 18,3 & 21,55 \\
\hline$\% \mathrm{CaO}$ & 34,4 & 34,07 & 33,81 & 31,81 & 32,97 & 33,02 & 26,95 & 31,72 \\
\hline$\% \mathrm{Na}_{2} \mathrm{O}$ & $<0.02$ & $<0.02$ & $<0.02$ & $<0.02$ & 0,07 & 0,08 & $<0.02$ & 0,09 \\
\hline$\% \mathrm{~K}_{2} \mathrm{O}$ & $<0.01$ & $<0.01$ & $<0.01$ & $<0.01$ & $<0.01$ & $<0.01$ & $<0.01$ & $<0.01$ \\
\hline$\% \mathrm{TiO}_{2}$ & $<0.007$ & $<0.007$ & $<0.007$ & $<0.007$ & $<0.007$ & $<0.007$ & $<0.007$ & $<0.007$ \\
\hline$\% \mathrm{P}_{2} \mathrm{O}_{5}$ & 0,018 & 0,032 & 0,015 & 0,042 & 0,015 & 0,016 & 0,094 & 0,018 \\
\hline$\% \mathrm{Fe}_{2} \mathrm{O}_{3}$ & $<0.01$ & $<0.01$ & 0,04 & $<0.01$ & $<0.01$ & $<0.01$ & $<0.01$ & 0,03 \\
\hline P.F. & 47,18 & 46,43 & 46,89 & 46,55 & 46,72 & 46,72 & 40,22 & 46,79 \\
\hline \%Total & 100,82 & 99,82 & 100,60 & 99,98 & 100,19 & 100,31 & 100,24 & 100,20 \\
\hline $\mathrm{Ba}(\mathrm{ppm})$ & $<37$ & $<37$ & $<37$ & $<37$ & $<37$ & $<37$ & $<37$ & $<37$ \\
\hline $\mathrm{Ce}(\mathrm{ppm})$ & $<35$ & $<35$ & $<35$ & $<35$ & $<35$ & $<35$ & $<35$ & $<35$ \\
\hline $\mathrm{Cl}$ (ppm) & $<50$ & $<50$ & 111 & $<50$ & $<50$ & $<50$ & $<50$ & $<50$ \\
\hline Co (ppm) & $<6$ & $<6$ & $<6$ & $<$ & $<$ & $<$ & $<$ & $<$ \\
\hline $\mathrm{Cr}(\mathrm{ppm})$ & $<13$ & $<13$ & $<13$ & $<13$ & $<13$ & $<13$ & $<13$ & $<13$ \\
\hline $\mathrm{Cu}(\mathrm{ppm})$ & 5 & $<5$ & $<5$ & $<5$ & $<$ & $<$ & $<$ & $<5$ \\
\hline$F(p p m)$ & $<550$ & $<550$ & $<550$ & 590 & $<550$ & $<550$ & $<550$ & $<550$ \\
\hline $\mathrm{Ga}(\mathrm{ppm})$ & $<9$ & $<9$ & $<9$ & $<9$ & $<9$ & $<9$ & $<9$ & $<$ \\
\hline La (ppm) & $<28$ & $<28$ & $<28$ & $<28$ & $<28$ & $<28$ & $<28$ & $<28$ \\
\hline $\mathrm{Nb}$ (ppm) & 9 & $<9$ & $<9$ & $<9$ & $<$ & $<9$ & $<$ & $<9$ \\
\hline $\mathrm{Nd}(\mathrm{ppm})$ & $<14$ & $<14$ & $<14$ & $<14$ & $<14$ & $<14$ & $<14$ & $<14$ \\
\hline $\mathrm{Ni}(\mathrm{ppm})$ & 5 & $<$ & $<$ & $<$ & $<$ & $<$ & $<$ & $<$ \\
\hline $\mathrm{Pb}(\mathrm{ppm})$ & 4 & $<$ & $<$ & $<$ & 4 & $<$ & $<$ & $<$ \\
\hline $\mathrm{Rb}(\mathrm{ppm})$ & 3 & $<$ & $<$ & $<$ & $<$ & $<$ & $<$ & $<$ \\
\hline S (ppm) & $<300$ & $<300$ & $<300$ & $<300$ & $<300$ & $<300$ & $<300$ & $<300$ \\
\hline Sc (ppm) & $<14$ & $<14$ & $<14$ & $<14$ & $<14$ & $<14$ & $<14$ & $<14$ \\
\hline $\mathrm{Sr}(\mathrm{ppm})$ & 65 & 92 & 103 & 42 & 58 & 58 & 26 & 37 \\
\hline Th (ppm) & 7 & 8 & $<$ & $<$ & 9 & 7 & $<$ & 7 \\
\hline U (ppm) & 3 & $<$ & $<$ & $<$ & 3 & $<$ & $<$ & $<$ \\
\hline V (ppm) & 12 & $<$ & 9 & 13 & $<$ & $<$ & $<$ & $<$ \\
\hline$Y(p p m)$ & 3 & 3 & 3 & 3 & 2 & 2 & 2 & 2 \\
\hline Zn (ppm) & 2 & 2 & 3 & 3 & 2 & $<$ & $<$ & 3 \\
\hline $\mathrm{Zr}(\mathrm{ppm})$ & 9 & 9 & 9 & 10 & 9 & 9 & 9 & 9 \\
\hline
\end{tabular}


Tabela 8.1.1 - Análise química de rocha total por FR-X para os dolomitos da Fazenda Ressaca.

\begin{tabular}{lrrrrrrrrr}
\hline Amostra & FR - 14 & FR - 15 & \multicolumn{2}{c}{ FR - 16 } & FR - 17 & FR - 19 & FR - 20 & FR - 25 \\
\hline$\% \mathrm{SiO}_{2}$ & 1,5 & $<0.03$ & $<0.03$ & $<0.03$ & 0,78 & $<0.03$ & $<0.03$ & 0,29 \\
\hline$\% \mathrm{Al}_{2} \mathrm{O}_{3}$ & $<0.01$ & $<0.01$ & $<0.01$ & $<0.01$ & $<0.01$ & $<0.01$ & 0,03 & 0,14 \\
\hline$\% \mathrm{MnO}$ & 0,011 & 0,009 & 0,002 & 0,002 & 0,002 & 0,003 & 0,009 & 0,018 \\
\hline$\% \mathrm{MgO}$ & 21,27 & 20,97 & 21,72 & 21,31 & 21,47 & 21,89 & 21,28 & 15,34 \\
\hline$\% \mathrm{CaO}$ & 30,98 & 32,01 & 31,27 & 31,23 & 30,73 & 31,19 & 31,8 & 36,73 \\
\hline$\% \mathrm{Na}_{2} \mathrm{O}$ & 0,03 & 0,05 & 0,03 & $<0.02$ & 0,05 & 0,05 & $<0.02$ & $<0.02$ \\
\hline$\% \mathrm{~K}_{2} \mathrm{O}$ & $<0.01$ & $<0.01$ & $<0.01$ & $<0.01$ & $<0.01$ & $<0.01$ & 0,03 & 0,17 \\
\hline$\% \mathrm{TiO}_{2}$ & $<0.007$ & $<0.007$ & $<0.007$ & $<0.007$ & $<0.007$ & $<0.007$ & 0,002 & 0,014 \\
\hline$\% \mathrm{P}_{2} \mathrm{O}_{5}$ & 0,01 & 0,022 & 0,013 & 0,014 & 0,015 & 0,024 & 0,561 & 12,527 \\
\hline$\% \mathrm{Fe}_{2} \mathrm{O}_{3}$ & 0,14 & 0,11 & $<0.01$ & $<0.01$ & $<0.01$ & $<0.01$ & 0,09 & 0,17 \\
\hline $\mathrm{P.F}$ & 45,54 & 46,2 & 46,48 & 46,48 & 46,18 & 46,36 & 45,68 & \\
\hline$\% \mathrm{Total}$ & 99,48 & 99,37 & 99,52 & 99,04 & 99,23 & 99,52 & 99,48 & 99,41 \\
\hline
\end{tabular}

\begin{tabular}{|c|c|c|c|c|c|c|c|c|}
\hline $\mathrm{Ba}(\mathrm{ppm})$ & $<37$ & $<37$ & $<37$ & $<37$ & $<37$ & $<37$ & $<37$ & 55 \\
\hline $\mathrm{Ce}(\mathrm{ppm})$ & $<35$ & $<35$ & $<35$ & $<35$ & $<35$ & $<35$ & $<35$ & 18 \\
\hline $\mathrm{Cl}$ (ppm) & $<50$ & $<50$ & $<50$ & $<50$ & $<50$ & $<50$ & $<50$ & $<50$ \\
\hline Co (ppm) & $<6$ & $<6$ & $<6$ & $<6$ & $<6$ & $<6$ & $<6$ & $<6$ \\
\hline $\mathrm{Cr}(\mathrm{ppm})$ & $<13$ & $<13$ & $<13$ & $<13$ & $<13$ & $<13$ & $<13$ & $<13$ \\
\hline $\mathrm{Cu}(\mathrm{ppm})$ & $<5$ & $<5$ & $<5$ & $<5$ & $<5$ & $<5$ & 5 & 9 \\
\hline $\mathrm{F}(\mathrm{ppm})$ & $<550$ & $<550$ & 691 & $<550$ & $<550$ & $<550$ & $<550$ & 7339 \\
\hline $\mathrm{Ga}(\mathrm{ppm})$ & $<9$ & $<9$ & $<9$ & $<9$ & $<9$ & $<9$ & $<9$ & $<9$ \\
\hline La (ppm) & $<28$ & $<28$ & $<28$ & $<28$ & $<28$ & $<28$ & $<28$ & $<28$ \\
\hline $\mathrm{Nb}(\mathrm{ppm})$ & $<9$ & $<9$ & $<9$ & $<9$ & $<9$ & $<9$ & $<9$ & $<9$ \\
\hline $\mathrm{Nd}(\mathrm{ppm})$ & $<14$ & $<14$ & $<14$ & $<14$ & $<14$ & $<14$ & $<14$ & $<14$ \\
\hline $\mathrm{Ni}(\mathrm{ppm})$ & $<5$ & $<$ & $<5$ & $<5$ & $<5$ & $<5$ & $<$ & $<5$ \\
\hline $\mathrm{Pb}(\mathrm{ppm})$ & 4 & $<$ & 4 & $<$ & $<$ & $<$ & $<$ & 4 \\
\hline $\mathrm{Rb}(\mathrm{ppm})$ & $<3$ & $<3$ & $<3$ & $<3$ & $<3$ & $<3$ & $<$ & $<3$ \\
\hline $\mathrm{S}(\mathrm{ppm})$ & $<300$ & $<300$ & $<300$ & $<300$ & $<300$ & $<300$ & $<300$ & $<300$ \\
\hline $\mathrm{Sc}(\mathrm{ppm})$ & $<14$ & $<14$ & $<14$ & $<14$ & $<14$ & $<14$ & $<14$ & $<14$ \\
\hline $\mathrm{Sr}(\mathrm{ppm})$ & 40 & 66 & 25 & 26 & 21 & 28 & 60 & 268 \\
\hline Th (ppm) & $<$ & 7 & 7 & $<$ & $<$ & 7 & 8 & 11 \\
\hline $\mathrm{U}(\mathrm{ppm})$ & 3 & 3 & 3 & $<$ & $<$ & $<$ & $<$ & $<$ \\
\hline$V(\mathrm{ppm})$ & 9 & 11 & 9 & $<$ & $<$ & $<$ & $<$ & $<$ \\
\hline$Y(p p m)$ & 3 & 3 & 2 & 3 & 2 & 3 & 3 & 6 \\
\hline Zn (ppm) & 6 & 5 & 2 & 2 & 2 & $<$ & 7 & 7 \\
\hline $\mathrm{Zr}(\mathrm{ppm})$ & 12 & 10 & 9 & 9 & 10 & 10 & 10 & 18 \\
\hline
\end{tabular}


Tabela 8.1.1 - Análise química de rocha total por FR-X para os dolomitos da Fazenda Ressaca.

\begin{tabular}{lcc}
\hline Padrão & \multicolumn{2}{c}{ IPT 48 } \\
& Obtido & Recomendado \\
\hline$\% \mathrm{SiO}_{2}$ & 0,41 & 0,45 \\
\hline$\% \mathrm{Al}_{2} \mathrm{O}_{3}$ & 0,14 & 0,17 \\
\hline$\% \mathrm{MnO}$ & 0,014 & 0,014 \\
\hline$\% \mathrm{MgO}$ & 21,31 & 21,2 \\
\hline$\% \mathrm{CaO}$ & 31,15 & 31 \\
\hline$\% \mathrm{Na}_{2} \mathrm{O}$ & 0,02 & 0,013 \\
\hline$\% \mathrm{~K}_{2} \mathrm{O}$ & 0,03 & 0,026 \\
\hline$\% \mathrm{TiO}_{2}$ & 0,005 & 0,006 \\
\hline$\% \mathrm{P}_{2} \mathrm{O}_{5}$ & 0,020 & 0,022 \\
\hline$\% \mathrm{Fe}_{2} \mathrm{O}_{3}$ & 0,17 & 0,17 \\
\hline $\mathrm{P.F.}$ & 46,9 & 46,9 \\
\hline$\% \mathrm{Total}_{2}$ & 100,17 & 99,97 \\
\hline
\end{tabular}

Para os elementos maiores, são expressivas apenas as concentrações de óxido de cálcio, em média superiores a $30 \%$, óxido de magnésio, em torno de $20 \%$, e elevada porcentagem de perda ao fogo, superior a $40 \%$, referente ao $\mathrm{CO}_{2}$ (Tabela 8.1.1). Essas concentrações são esperadas para dolomitos.

A concentração de $\mathrm{P}_{2} \mathrm{O}_{5}$ é baixa nos dolomitos e mantém-se relativamente estável em toda a coluna estratigráfica. Apenas eleva-se o teor na amostra 25, que compreende ao conglomerado polimítico com clastos de fosforitos, na base da Formação Tamengo, apresentando teor de $12,5 \%$ de $\mathrm{P}_{2} \mathrm{O}_{5}$.

Não se pode concluir, portando, que o teor de fósforo aumentou gradativamente e significativamente ao longo da coluna, culminando na deposição de um sedimento predominantemente fosfático.

Para os outros elementos maiores analisados, representados sob a forma de óxidos, não apresentam teores significativos, estando a maior parte deles abaixo do limite de detecção do aparelho, bem como os elementos traços. Da mesma forma, os elementos que representam a fração terrígena ( $\mathrm{Al}$ e K) também se encontram abaixo do limite de detecção, o que sugere sedimentação autigênica sem contribuição significativa de sedimentos siliciclásticos.

O elemento $\mathrm{Sr}$, cuja concentração não ultrapassa 103 ppm para os dolomitos da Formação Bocaina, sendo superior apenas no conglomerado da base da Formação Tamengo, apresenta boa correlação com o Ca $(r=0,7242)$ (Figura 8.1.1), o que sugere que o $\mathrm{Sr}$ foi incorporado na estrutura dos minerais carbonáticos durante a precipitação. 


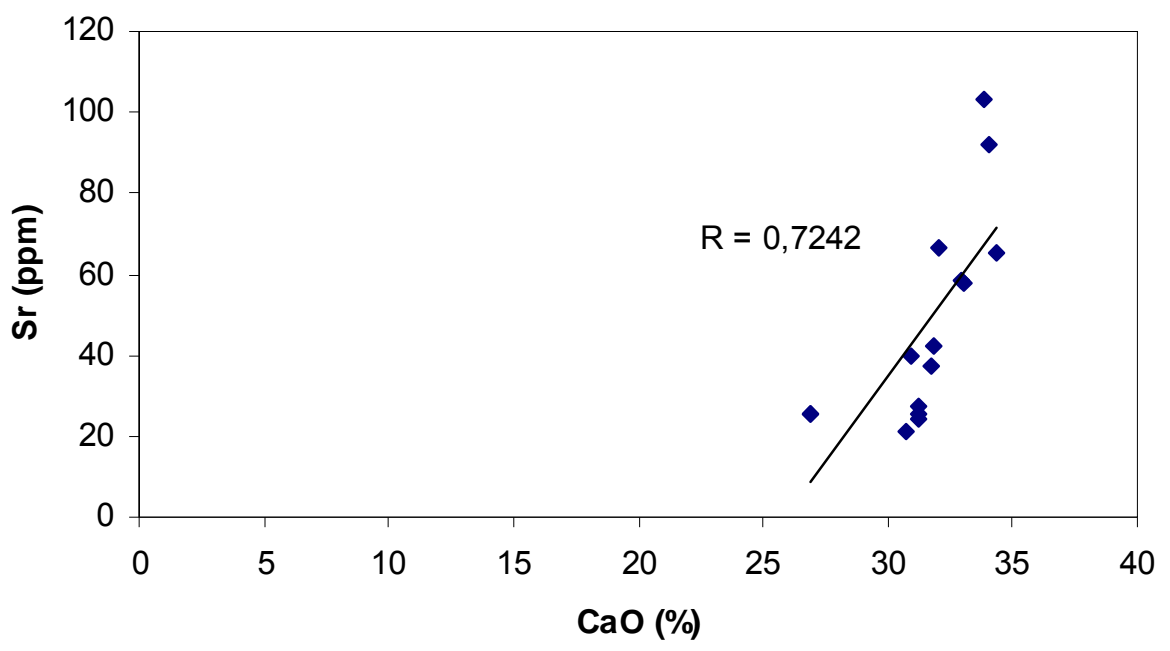

Figura 8.1.1 - Gráfico de correlação entre $\mathrm{CaO}$ e Sr para dolomitos.

\subsection{Isótopos de C e O dos dolomitos}

As análises de isótopos estáveis de carbono e oxigênio foram realizadas em 22 amostras de dolomitos da Fazenda Ressaca. Os resultados para isótopos de C e O estão representados na tabela 8.2.1.

Os valores de $\delta^{13} \mathrm{C}_{\text {PDB }}$ podem indicar o ambiente diagnético em que se formaram os dolomitos. Os valores muito negativos ( - $15 \%$ ) são relacionados a fracionamento por microorganismos, indicativos de processos de sulfato-redução. Já valores elevados de $\delta^{13} \mathrm{C}$ $(\sim+15 \%)$ referem-se a processos de metanogênese (BURNS; BAKER, 1987; COMPTON et al., 1994; MAZZULLO, 2000). Valores ligeiramente positivos indicam ambientes oxidantes.

Os valores de $\delta^{18} \mathrm{O}$ são bem sensíveis às variações ambientais, como a temperatura, e a inclusão de fluidos externos durante a formação da rocha. Por isso, não são utilizados em correlações estratigráficas, e sim aplicados em estudos de paleotemperatura em ocorrências modernas.

Para os dolomitos da Fazenda Ressaca, os valores de $\delta^{13} \mathrm{C}_{\mathrm{PDB}}$ são todos positivos, variando entre $+0,95 \%$ o e $+3,15 \%$, com exceção da amostra FR-12, cuja assinatura de $C$ é negativa (Figura 8.2.1). Estes valores não são representativos de zona de sulfato-redução, mas podem refletir pequena contribuição de fracionamento metanogenético, já que se apresentam ligeiramente positivos. Esses valores são mais comumente encontrados em rochas sedimentares marinhas formadas em ambientes oxigenados. Os valores de $\delta^{18} \mathrm{O}_{\mathrm{PDB}}$ são todos negativos, variando entre $-0,34 \%$ e $-6,52 \%$, o que indica que estas rochas não atingiram temperaturas muito elevadas durante a diagênese e nem foram afetadas por processos diagenéticos intensos. 
Tabela 8.2.1 - Isótopos de C e O para dolomitos da Fazenda Ressaca.

\begin{tabular}{cccc}
\hline Amostra & Fácies & $\delta^{13} \mathrm{C}_{\mathrm{VPDB}} \%$ & $\delta^{18} \mathrm{O}_{\mathrm{VPDB}} \%$ \\
\hline FR 01 & Grainstone oolítico inferior & 1.24 & -4.37 \\
FR 02 & Grainstone oolítico inferior & 2.07 & -3.58 \\
FR-03 & Grainstone oolítico inferior & 2.44 & -4.08 \\
FR-04 & Boundstone LLH & 2.62 & -3.51 \\
FR 05a & Boundstone LLH & 1.64 & -6.36 \\
FR-06a & Boundstone LLH & 1.73 & -5.26 \\
FR 06a' & Boundstone LLH & 2.30 & -2.24 \\
FR 06a" & Boundstone LLH & 2.56 & -3.53 \\
FR-07 & Boundstone LLH & 0.95 & -3.30 \\
FR-08 & Boundstone LLH & 1.79 & -4.40 \\
FR 09 & Boundstone LLH & 2.19 & -6.52 \\
FR-10 & Boundstone SH & 3.15 & -3.91 \\
FR 13 & Boundstone SH & 2.32 & -2.21 \\
FR 12 & Boundstone SH & -0.47 & -3.83 \\
FR 15 & Rudstone intrclástico & 1.40 & -2.79 \\
FR 16 & Boundstone SH & 1.74 & -4.53 \\
FR-17 & Mudstone maciço & 1.96 & -1.70 \\
FR 18 & Grainstone oolítico superior & 2.17 & -0.34 \\
FR 19 & Grainstone oolítico superior & 2.71 & -1.18 \\
FR 20 & Rudstone intrclástico & 2.56 & -1.31 \\
\hline & & &
\end{tabular}



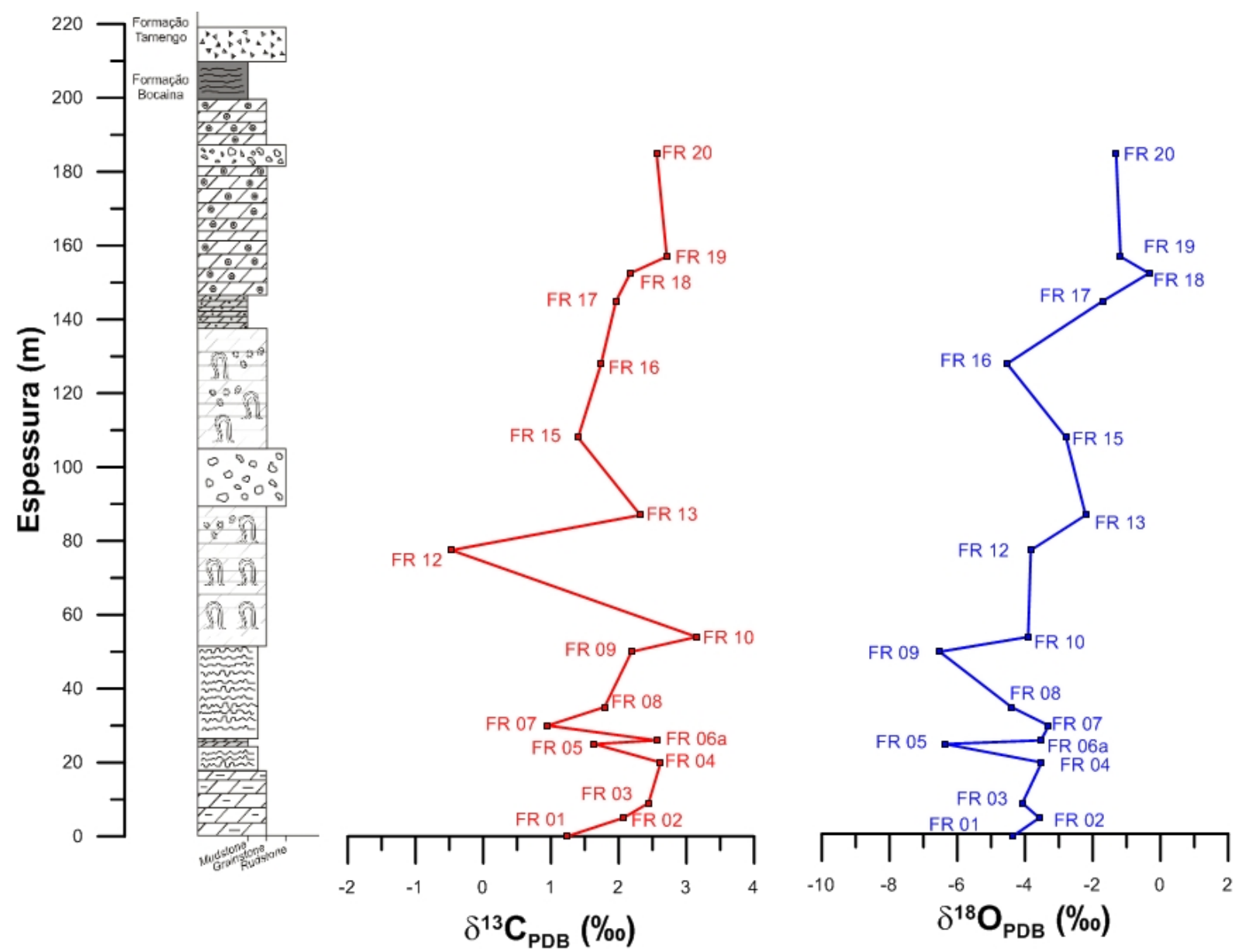

Figura 8.2.1 - Variação dos valores de $\delta^{13} \mathrm{C}$ e $\delta^{18} \mathrm{O}$ ao longo da coluna estratigráfica da Fazenda Ressaca.

Os dados isotópicos da Formação Bocaina foram confrontados com os disponíveis na literatura, plotando-se os valores de $\delta^{13} \mathrm{C}$ no eixo das ordenadas e os valores de $\delta^{18} \mathrm{O}$ no eixo das abscissas. Assim, observa-se que os dolomitos da Fazenda Ressaca não estão dispostos na zona de sulfato-redução (valores negativos de $\delta^{13} \mathrm{C}_{\mathrm{VPDB}}$ ) e podem ter pequena contribuição do processo de metanogênese (valores positivos de $\delta^{13} \mathrm{C}_{\mathrm{VPDB}}$ ) (Figura 8.2.2). Os valores isotópicos corroboram com a interpretação de que estas rochas foram depositadas em condições oxidantes, semelhantes à água do mar atual. 


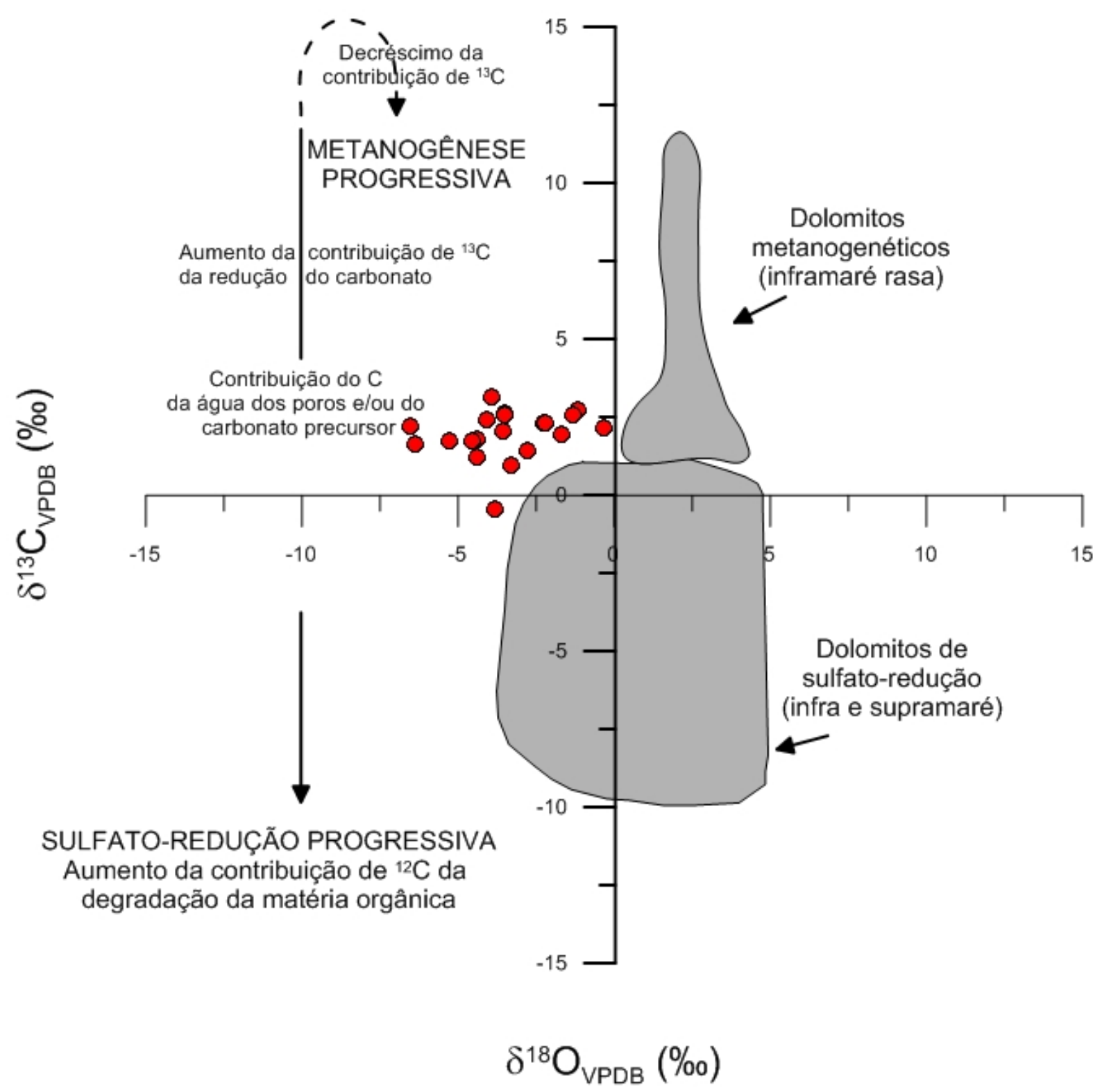

Figura 8.2.2 - Gráfico da composição isotópica para dolomitos organogênicos. No eixo das ordenadas, os valores de $\delta^{13} \mathrm{C}$, e no eixo das abscissas, valores de $\delta^{18} \mathrm{O}$. Os valores isotópicos para a Fazenda Ressaca (pontos em vermelho) foram plotados juntos aos dados compilados de Mazzullo (2000).

\subsection{Geoquímica elementar dos fosforitos}

As análises de elementos maiores, menores e traços para quatro amostras de fosforitos da Fazenda Ressaca foram realizadas por ICP-OES. Duas amostras possuem controle estratigráfico, FR-22 e FR-24, e duas não possuem controle estratigráfico, FR-A e FR-B.

Os resultados estão apresentados na tabela 8.3.1. As amostras foram analisadas também pelo ICP-MS, visando à quantificação dos elementos de terras raras. Porém 
apresentam bons resultados para elementos traços, alguns apresentados separadamente na tabela 8.3.2.

A amostra FR-22 foi realizada uma análise multiespectral no ICP-MS para os modos quantitativos e qualitativos que abrange todos os elementos da tabela periódica. Os resultados desta análise estão apresentados na tabela 8.3.3.

Os dados obtidos são confiáveis, pois as análises totalizam valores próximos a $100 \%$ (máximo 102\% e mínimo 100,10\%). A análise da duplicata apresenta-se muito semelhante, o que é um bom indicativo da qualidade das análises, assim como os padrões analisados também apresentam valores muito próximos aos recomendados pelos certificados.

Pode-se observar os valores elevados para $\mathrm{CaO}$ e $\mathrm{P}_{2} \mathrm{O}_{5}$, que totalizam quase $100 \%$ da rocha, tendo em vista que o cálcio e o fósforo são os componentes essenciais dos minerais do grupo da apatita, presentes nestes fosforitos.

A mineralogia, confirmada por difração de raio-x, também registra apenas apatita para os fosforitos da Fazenda Ressaca, como mostra o Anexo 1 - Figura 3. Em algumas amostras, aparece também quartzo.

O percentual de perda ao fogo (P.F.) está em torno de $1 \%$, representado provavelmente o flúor, presente no mineral flúor-apatita.

Os elementos que representam à fração terrígena $(\mathrm{Si}, \mathrm{Al}$ e $\mathrm{K})$ possuem concentrações baixas nos fosforitos da Fazenda Ressaca, o que indica reduzida contribuição de sedimentos terríginos na formação destas rochas.

Os outros elementos menores também apresentam concentrações muito baixas, como no caso do ferro que varia de 0,12 a $0,25 \%$, podendo estar relacionado ao ferro adsorvido nas partículas de argila, que são observadas ao microscópio petrográfico. Já o sódio e o manganês estão abaixo limite de detecção do aparelho.

O magnésio apresenta concentrações baixíssimas, em torno de 0,04 a 0,28\%, possivelmente porque a precipitação dos minerais carbonáticos antecedem a precipitação dos minerais fosfáticos, consumindo primeiramente o magnésio (SÁNCHEZ-ROMÁN et al., 2007).

Para os elementos traços, observa-se valores, para o elemento bário, em torno de 28 e 175 ppm quando analisado pelo ICP-OES (Tabela 8.3.1) e variando entre 31,5 e 186 ppm, quando analisado pelo ICP-MS (Tabela 8.3.3). Estes valores podem ser considerados empobrecidos quanto comparados à média para fosforitos (ALTSCHULER, 1980) (Tabela 8.3.3). O elemento $\mathrm{Sr}$ apresenta valores elevados, em torno de $420 \mathrm{ppm}$ ou superiores a 800 ppm, próximos à média mundial para os fosforitos (ALTSCHULER, 1980). Para outros elementos traços, as análises pelo ICP-OES estão abaixo do limite de detecção do aparelho. 
Tabela 8.3.1 - Análise química de elementos maiores, menores e traços por ICP-OES para os fosforitos da Fazenda Ressaca.

\begin{tabular}{|c|c|c|c|c|c|c|c|c|c|c|}
\hline Amostra & FR-A1 & FR-A2 & FR-B & FR-22 & FR-24 & $\mathrm{BCO}$ & $\begin{array}{l}\text { NIST-2771 } \\
\text { Obtido }\end{array}$ & $\begin{array}{c}\text { NIST-2711 } \\
\text { Recomendado }\end{array}$ & $\begin{array}{c}\text { NIST-694 } \\
\text { Obtido } \\
\end{array}$ & $\begin{array}{c}\text { NIST-694 } \\
\text { Recomendado }\end{array}$ \\
\hline$\% \mathrm{SiO}_{2}$ & 2,32 & 2,28 & 1,69 & 3,92 & 1,12 & 0,06 & 65,29 & $65,11 \pm 0,41$ & 12,08 & $11,20 \pm 0,40$ \\
\hline$\% \mathrm{Al}_{2} \mathrm{O}_{3}$ & 0,88 & 0,86 & 0,65 & 1,13 & 0,64 & 0,04 & 12,18 & $12,34 \pm 0,17$ & 2,07 & $1,80 \pm 0,10$ \\
\hline$\% \mathrm{Fe}_{2} \mathrm{O}_{3}$ & 0,13 & 0,13 & 0,12 & 0,25 & 0,25 & $<0,01$ & 4,27 & $4,13 \pm 0,08$ & 0,81 & $0,79 \pm 0,06$ \\
\hline$\% \mathrm{MgO}$ & 0,27 & 0,28 & 0,18 & 0,04 & 0,04 & $<0,01$ & 1,73 & $1,74 \pm 0,05$ & 0,33 & $0,33 \pm 0,02$ \\
\hline$\% \mathrm{CaO}$ & 54,91 & 55,42 & 57,86 & 53,52 & 57,42 & $<0,01$ & 4,16 & $4,03 \pm 0,11$ & 45,39 & $43,60 \pm 0,40$ \\
\hline$\% \mathrm{Na}_{2} \mathrm{O}$ & $<0,01$ & $<0,01$ & $<0,01$ & 0,13 & 0,01 & $<0,01$ & 1,70 & $1,54 \pm 0,04$ & 0,89 & $0,86 \pm 0,04$ \\
\hline$\% \mathrm{~K}_{2} \mathrm{O}$ & 0,23 & 0,22 & 0,19 & 0,18 & 0,11 & $<0,03$ & 2,97 & $2,95 \pm 0,10$ & 0,55 & $0,51 \pm 0,02$ \\
\hline$\% \mathrm{P}_{2} \mathrm{O}_{5}$ & 40,20 & 39,79 & 40,15 & 40,05 & 41,49 & $<0,01$ & 0,19 & $0,197 \pm 0,016$ & 30,22 & $30,2 \pm 0,10$ \\
\hline$\% \mathrm{MnO}$ & $<0,006$ & $<0,006$ & $<0,006$ & 0,009 & $<0,006$ & $<0,006$ & 0,091 & $0,082 \pm 0,004$ & 0,013 & $0,0116 \pm 0,0012$ \\
\hline$\% \mathrm{TiO}_{2}$ & 0,052 & 0,051 & 0,014 & 0,048 & 0,028 & $<0,006$ & 0,518 & $0,51 \pm 0,04$ & 0,118 & 0,11 \\
\hline \%P.F. & 1,11 & 1,12 & 1,16 & 1,04 & 0,73 & & & & & \\
\hline \%Total & 100,10 & 100,15 & 102,00 & 100,32 & 101,84 & & 93,10 & & 92,48 & \\
\hline $\mathrm{Ba}(\mathrm{ppm})$ & 85 & 87 & 66 & 175 & 28 & $<10$ & 719 & $726 \pm 38$ & 109 & n.d. \\
\hline $\mathrm{Sr}(\mathrm{ppm})$ & 419 & 423 & 437 & 761 & 848 & 7 & 259 & $245,3 \pm 0,7$ & 955 & n.d. \\
\hline $\mathrm{V}(\mathrm{ppm})$ & $<15$ & $<15$ & $<15$ & $<15$ & $<15$ & $<15$ & 73 & $81,6 \pm 2,9$ & 1665 & $1736 \pm 392$ \\
\hline $\mathrm{Y}(\mathrm{ppm})$ & $<10$ & $<10$ & $<10$ & $<10$ & 16 & $<10$ & 26 & 25 & 135 & n.d. \\
\hline $\mathrm{Zr}(\mathrm{ppm})$ & $<25$ & $<25$ & $<25$ & $<25$ & $<25$ & $<25$ & 295 & 230 & $<25$ & n.d. \\
\hline
\end{tabular}


Tabela 8.3.2 - Análise química multiespectral pelo ICP-MS da amostra FR-22 (ppm).

\begin{tabular}{|c|c|c|c|c|c|}
\hline Elemento & $\begin{array}{c}\text { BR } \\
\text { Semi Quantitativa }\end{array}$ & $\begin{array}{c}\text { BR } \\
\text { Quantitativa }\end{array}$ & $\begin{array}{c}\text { Valor } \\
\text { recomendado }\end{array}$ & $\begin{array}{c}\text { FR-22 } \\
\text { Semi Quantitativa }\end{array}$ & $\begin{array}{c}\text { FR-22 } \\
\text { Quantitativa } \\
\end{array}$ \\
\hline $\mathrm{Li}$ & 11,736 & & & 2,548 & \\
\hline $\mathrm{Be}$ & 1,34 & & & 0,514 & \\
\hline $\mathrm{B}$ & 3,868 & & & 2,188 & \\
\hline $\mathrm{C}$ & 0 & & & 0,000 & \\
\hline $\mathrm{N}$ & 67176660,04 & & & 0,000 & \\
\hline $\mathrm{Na}$ & 16890,139 & & & 1431,629 & \\
\hline $\mathrm{Mg}$ & 62503,17 & & & 446,233 & \\
\hline $\mathrm{Al}$ & 33890,547 & & & 5245,878 & \\
\hline $\mathrm{Si}$ & 64,568 & & & 0,000 & \\
\hline $\mathrm{P}$ & 2533,205 & & & 194659,962 & \\
\hline $\mathrm{S}$ & 0 & & & 0,000 & \\
\hline $\mathrm{Cl}$ & 0 & & & 0,000 & \\
\hline $\mathrm{K}$ & 9126,827 & & & 809,655 & \\
\hline $\mathrm{Ca}$ & 0 & & & 167489,286 & \\
\hline Sc & 17,944 & 21,5 & 25 & 0,381 & 0,57 \\
\hline $\mathrm{Ti}$ & 13449,154 & & & 314,737 & \\
\hline $\mathrm{V}$ & 229,236 & & & 9,891 & \\
\hline $\mathrm{Cr}$ & 614,312 & & & 28,297 & \\
\hline $\mathrm{Mn}$ & 1276,278 & & & 66,926 & \\
\hline $\mathrm{Fe}$ & 74660,146 & & & 1935,696 & \\
\hline Co & 52,95 & & & 2,714 & \\
\hline $\mathrm{Ni}$ & 253,311 & & & 8,548 & \\
\hline $\mathrm{Cu}$ & 69,175 & & & 6,363 & \\
\hline $\mathrm{Zn}$ & 118,131 & & & 155,915 & \\
\hline $\mathrm{Ga}$ & 14,609 & & & 2,738 & \\
\hline $\mathrm{Ge}$ & 1,055 & & & 0,055 & \\
\hline As & 2,278 & & & 2,379 & \\
\hline $\mathrm{Se}$ & 0 & & & 0,000 & \\
\hline $\mathrm{Br}$ & 0 & & & 0,000 & \\
\hline $\mathrm{Rb}$ & 40,541 & 49,9 & 47 & 4,434 & 3,35 \\
\hline $\mathrm{Sr}$ & 1026,174 & 1403 & 1320 & 884,795 & 707 \\
\hline $\mathrm{Y}$ & 22,644 & 26,4 & 30 & 9,777 & 6,94 \\
\hline $\mathrm{Zr}$ & 220,036 & 270 & 260 & 11,678 & 10,7 \\
\hline $\mathrm{Nb}$ & 48,751 & 109 & 98 & 0,515 & 0,26 \\
\hline Mo & 1,915 & & & 1,222 & \\
\hline $\mathrm{Ru}$ & 0,009 & & & 0,002 & \\
\hline $\mathrm{Rh}$ & 0,062 & & & 0,052 & \\
\hline $\mathrm{Pd}$ & 1,927 & & & 0,125 & \\
\hline $\mathrm{Ag}$ & 1,158 & & & 0,061 & \\
\hline $\mathrm{Cd}$ & 0,102 & & & 2,193 & \\
\hline In & 0,047 & & & 0,002 & \\
\hline Sn & 1,351 & & & 0,127 & \\
\hline
\end{tabular}


Tabela 8.3.2 - Análise química multiespectral pelo ICP-MS da amostra FR-22 (ppm).

\begin{tabular}{|c|c|c|c|c|c|}
\hline Elemento & $\begin{array}{c}\text { BR } \\
\text { Semi Quantitativa }\end{array}$ & $\begin{array}{c}\text { BR } \\
\text { Quantitativa } \\
\end{array}$ & $\begin{array}{c}\text { Valor } \\
\text { recomendado }\end{array}$ & $\begin{array}{c}\text { FR-22 } \\
\text { Semi Quantitativa }\end{array}$ & $\begin{array}{c}\text { FR-22 } \\
\text { Quantitativa }\end{array}$ \\
\hline $\mathrm{Sb}$ & 0,128 & & & 0,310 & \\
\hline $\mathrm{Te}$ & 0 & & & 0,036 & \\
\hline 1 & 0 & & & 0,029 & \\
\hline Cs & 0,666 & 0,77 & 0,8 & 0,810 & 0,73 \\
\hline $\mathrm{Ba}$ & 966,848 & 1050 & 1050 & 190,830 & 167 \\
\hline La & 90,096 & 81,8 & 82 & 5,683 & 4,94 \\
\hline $\mathrm{Ce}$ & 136,509 & 146 & 151 & 13,910 & 11,6 \\
\hline $\mathrm{Pr}$ & 12,1 & 17,1 & 17 & 1,163 & 1,08 \\
\hline $\mathrm{Nd}$ & 59,385 & 65,4 & 65 & 5,844 & 4,81 \\
\hline $\mathrm{Sm}$ & 12,404 & 11,3 & 12,2 & 1,257 & 1,11 \\
\hline $\mathrm{Eu}$ & 3,697 & 3,54 & 3,7 & 0,289 & 0,21 \\
\hline Gd & 10,85 & 9,64 & 9,5 & 1,295 & 1,06 \\
\hline $\mathrm{Tb}$ & 1,444 & 1,19 & 1,25 & 0,186 & 0,15 \\
\hline Dy & 6,04 & 6,36 & 6,4 & 1,014 & 0,93 \\
\hline $\mathrm{Ho}$ & 0,963 & 1,04 & 1,1 & 0,198 & 0,20 \\
\hline $\mathrm{Er}$ & 2,438 & 2,49 & 2,5 & 0,619 & 0,59 \\
\hline $\mathrm{Tm}$ & 0,318 & 0,30 & 0,3 & 0,093 & 0,08 \\
\hline $\mathrm{Yb}$ & 1,877 & 1,79 & 1,8 & 0,548 & 0,51 \\
\hline Lu & 0,261 & 0,25 & 0,25 & 0,089 & 0,08 \\
\hline $\mathrm{Hf}$ & 5,234 & 5,66 & 5,6 & 0,261 & 0,24 \\
\hline $\mathrm{Ta}$ & 2,818 & 5,86 & 6,2 & 0,072 & 0,05 \\
\hline W & 0,631 & & & 0,371 & \\
\hline $\mathrm{Re}$ & 0 & & & 0,000 & \\
\hline Os & 0 & & & 0,000 & \\
\hline $\mathrm{Ir}$ & 0,001 & & & 0,000 & \\
\hline $\mathrm{Pt}$ & 0,034 & & & 0,000 & \\
\hline $\mathrm{Au}$ & 0 & & & 0,000 & \\
\hline $\mathrm{Hg}$ & 0 & & & 0,000 & \\
\hline $\mathrm{Tl}$ & 0,037 & & & 0,017 & \\
\hline $\mathrm{Pb}$ & 5,536 & 5,40 & 5 & 4,143 & 4,88 \\
\hline $\mathrm{Bi}$ & 0,008 & & & 0,022 & \\
\hline Th & 9,041 & 11,0 & 11 & 0,673 & 0,79 \\
\hline$U$ & 3,716 & 2,32 & 2,5 & 19,981 & 11,4 \\
\hline
\end{tabular}


Tabela 8.3.3 - Elementos traços em fosforito analisados pelo ICP-MS (ppm).

\begin{tabular}{ccccccccc}
\hline Elemento & $\begin{array}{c}\text { BR } \\
\text { obtido }\end{array}$ & $\begin{array}{c}\text { BR } \\
\text { recomendado }\end{array}$ & FR-A & FR-B & FR-24 & FR-22 & FR-22a & $\begin{array}{c}\text { Média de } \\
\text { fosforitos* }\end{array}$ \\
\hline $\mathrm{Rb}$ & 45,2 & 47 & 5,17 & 3,83 & 1,06 & 3,46 & 3,74 & - \\
\hline $\mathrm{Sr}$ & 1282 & 1320 & 397 & 368 & 782 & 690 & 758 & 750 \\
\hline $\mathrm{Y}$ & 28,7 & 30,0 & 6,75 & 7,53 & 17,5 & 7,88 & 8,28 & 260 \\
\hline $\mathrm{Zr}$ & 255 & 260 & 5,18 & 1,92 & 9,06 & 44,7 & 7,16 & 70 \\
\hline $\mathrm{Nb}$ & 102 & 98 & 2,37 & 1,34 & 1,77 & 1,75 & 2,01 & - \\
\hline $\mathrm{Cs}$ & 0,80 & 0,80 & 0,50 & 0,43 & 0,24 & 0,83 & 0,83 & - \\
\hline $\mathrm{Ba}$ & 1078 & 1050 & 94,1 & 68,1 & 31,5 & 186 & 181 & 350 \\
\hline $\mathrm{Hf}$ & 5,95 & 5,60 & 0,19 & 0,11 & 0,42 & 1,27 & 0,25 & - \\
\hline $\mathrm{Ta}$ & 6,09 & 6,20 & 0,04 & 0,00 & 0,07 & 0,14 & 0,02 & - \\
\hline $\mathrm{Pb}$ & 6,22 & 5,00 & 5,00 & 5,75 & 4,53 & 5,37 & 4,97 & 50 \\
\hline $\mathrm{Th}$ & 10,96 & 11,0 & 1,45 & 0,51 & 1,17 & 1,22 & 1,17 & - \\
\hline $\mathrm{U}$ & 2,55 & 2,50 & 12,4 & 17,9 & 13,9 & 13,3 & 12,9 & 120 \\
\hline & & & & & & & \\
\end{tabular}

\subsection{Elementos de terras raras para fosforitos}

Primeiramente foi analisada apenas uma amostra de fosforito (FR-22) pelo método do ICP-MS. Obteve-se uma análise quantitativa e uma semi-quantitativa, visando os elementos de terras raras. Posteriormente, foram encaminhadas ao laboratório outras três amostras de fosforito (FR-A, FR-B e FR-24) das quais existe análise de elementos maiores, menores e traços pelo método do ICP-OES, para analisar também os elementos de terras raras e comparar os resultados dos dois métodos. A amostra FR-22 foi reanalisada com a finalidade de duplicata.

$\mathrm{Na}$ tabela 8.3.2 são apresentados os dados para todos os elementos da tabela periódica, obtidos na primeira análise realizada com a amostra FR-22 e a tabela 8.4.1, os dados exclusivos ETR tanto da primeira como segunda análise. 
Tabela 8.4.1 - Análise química de ETR para fosforito pelo ICP-MS (ppm).

\begin{tabular}{cccccccc}
\hline ETR & $\begin{array}{c}\text { BR } \\
\text { obtido }\end{array}$ & $\begin{array}{c}\text { Brecomendado } \\
\text { rem-A }\end{array}$ & FR-B & FR-24 & FR-22 & FR-22a \\
\hline $\mathrm{La}$ & 81,7 & 82,0 & 5,71 & 3,77 & 6,04 & 6,00 & 5,94 \\
\hline $\mathrm{Ce}$ & 154 & 151 & 12,82 & 10,53 & 18,49 & 15,62 & 15,48 \\
\hline $\mathrm{Pr}$ & 17,7 & 17 & 1,19 & 0,68 & 1,44 & 1,40 & 1,36 \\
\hline $\mathrm{Nd}$ & 68,0 & 65,0 & 4,96 & 3,53 & 6,82 & 6,20 & 6,02 \\
\hline $\mathrm{Sm}$ & 12,4 & 12,2 & 1,04 & 0,81 & 1,62 & 1,33 & 1,27 \\
\hline $\mathrm{Eu}$ & 3,77 & 3,70 & 0,20 & 0,18 & 0,34 & 0,28 & 0,26 \\
\hline $\mathrm{Gd}$ & 9,83 & 9,50 & 1,05 & 1,00 & 2,04 & 1,40 & 1,30 \\
\hline $\mathrm{Tb}$ & 1,34 & 1,25 & 0,16 & 0,15 & 0,30 & 0,20 & 0,19 \\
\hline $\mathrm{Dy}$ & 6,65 & 6,40 & 0,99 & 0,96 & 1,92 & 1,21 & 1,13 \\
\hline $\mathrm{Ho}$ & 1,13 & 1,10 & 0,22 & 0,23 & 0,48 & 0,26 & 0,24 \\
\hline $\mathrm{Er}$ & 2,74 & 2,50 & 0,62 & 0,68 & 1,48 & 0,76 & 0,70 \\
\hline $\mathrm{Tm}$ & 0,33 & 0,30 & 0,09 & 0,10 & 0,22 & 0,11 & 0,10 \\
\hline $\mathrm{Yb}$ & 1,84 & 1,80 & 0,54 & 0,61 & 1,39 & 0,68 & 0,61 \\
\hline $\mathrm{Lu}$ & 0,27 & 0,25 & 0,08 & 0,09 & 0,22 & 0,10 & 0,09 \\
\hline$\Sigma \mathrm{ETR}$ & 361,7 & 354 & 29,68 & 23,32 & 42,78 & 35,55 & 34,69 \\
\hline
\end{tabular}

\begin{tabular}{cccccc}
\hline ETR & $\begin{array}{c}\text { BR } \\
\text { obtido }\end{array}$ & $\begin{array}{c}\text { BR } \\
\text { recomendado }\end{array}$ & $\begin{array}{c}\text { FR-22 } \\
\text { Semi Quantit. }\end{array}$ & $\begin{array}{c}\text { FR-22 } \\
\text { Quantitativa }\end{array}$ & $\begin{array}{c}\text { Média dos } \\
\text { fosforitos* }\end{array}$ \\
\hline $\mathrm{La}$ & 81,8 & 82,0 & 5,683 & 4,94 & 133 \\
\hline $\mathrm{Ce}$ & 146 & 151 & 13,910 & 11,6 & 104 \\
\hline $\mathrm{Pr}$ & 17,1 & 17 & 1,163 & 1,08 & 21 \\
\hline $\mathrm{Nd}$ & 65,4 & 65,0 & 5,844 & 4,81 & 98 \\
\hline $\mathrm{Sm}$ & 11,3 & 12,2 & 1,257 & 1,11 & 20 \\
\hline $\mathrm{Eu}$ & 3,54 & 3,70 & 0,289 & 0,21 & 6,5 \\
\hline $\mathrm{Gd}$ & 9,64 & 9,50 & 1,295 & 1,06 & 12,8 \\
\hline $\mathrm{Tb}$ & 1,19 & 1,25 & 0,186 & 0,15 & 3,2 \\
\hline $\mathrm{Dy}$ & 6,36 & 6,40 & 1,014 & 0,93 & 19,2 \\
\hline $\mathrm{Ho}$ & 1,04 & 1,10 & 0,198 & 0,20 & 4,2 \\
\hline $\mathrm{Er}$ & 2,49 & 2,50 & 0,619 & 0,59 & 23,3 \\
\hline $\mathrm{Tm}$ & 0,30 & 0,30 & 0,093 & 0,08 & 1,2 \\
\hline $\mathrm{Yb}$ & 1,79 & 1,80 & 0,548 & 0,51 & 12,6 \\
\hline $\mathrm{Lu}$ & 0,25 & 0,25 & 0,089 & 0,08 & 2,7 \\
\hline$\Sigma \mathrm{ETR}$ & 348,2 & 354 & 32,188 & 27,35 & 462 \\
\hline
\end{tabular}

* Segundo Altschuler (1980) 
O conteúdo total de ETR varia entre 23,32 e 42,78 ppm, que são concentrações baixas quando comparados a outros fosforitos (RAO et al., 2002), porém esperadas para fosforitos primários (em torno de $15 \mathrm{ppm}$ ) em contrapartida a fosforitos retrabalhados (em média 650 ppm) (ILYIN, 1998).

Quando as concentrações de ETR são normalizadas para o folhelho PAAS (MCLENNAN, 1989) (Tabela 8.4.2), observa-se o padrão de distribuição dos ETR (Figura 8.4.1).

Tabela 8.4.2 - Concentrações (ppm) de ETR normalizadas para Folhelho PAAS.

\begin{tabular}{cccccccc}
\hline ETR & PAAS* $^{*}$ & FR-A $_{\mathbf{n}}$ & FR-B $_{\mathbf{n}}$ & FR-24 $_{\mathbf{n}}$ & \multicolumn{2}{c}{ FR-22 $_{\mathbf{n}}$} & $\begin{array}{c}\text { Média dos } \\
\text { fosforitos }\end{array}$ \\
\hline $\mathrm{La}$ & 38,2 & 0,15 & 0,10 & 0,16 & 0,16 & 0,16 & 3,48 \\
\hline $\mathrm{Ce}$ & 79,6 & 0,16 & 0,13 & 0,23 & 0,20 & 0,19 & 1,31 \\
\hline $\mathrm{Pr}$ & 8,83 & 0,13 & 0,08 & 0,16 & 0,16 & 0,15 & 2,38 \\
\hline $\mathrm{Nd}$ & 33,9 & 0,15 & 0,10 & 0,20 & 0,18 & 0,18 & 2,89 \\
\hline $\mathrm{Sm}$ & 5,55 & 0,19 & 0,15 & 0,29 & 0,24 & 0,23 & 3,60 \\
\hline $\mathrm{Eu}$ & 1,08 & 0,18 & 0,16 & 0,31 & 0,26 & 0,24 & 6,02 \\
\hline $\mathrm{Gd}$ & 4,66 & 0,23 & 0,21 & 0,44 & 0,30 & 0,28 & 2,75 \\
\hline $\mathrm{Tb}$ & 0,774 & 0,20 & 0,19 & 0,39 & 0,26 & 0,24 & 4,13 \\
\hline $\mathrm{Dy}$ & 4,68 & 0,21 & 0,21 & 0,41 & 0,26 & 0,24 & 4,10 \\
\hline $\mathrm{Ho}$ & 0,991 & 0,22 & 0,23 & 0,48 & 0,26 & 0,25 & 4,24 \\
\hline $\mathrm{Er}$ & 2,85 & 0,22 & 0,24 & 0,52 & 0,27 & 0,24 & 8,18 \\
\hline $\mathrm{Tm}$ & 0,405 & 0,22 & 0,25 & 0,55 & 0,27 & 0,25 & 2,96 \\
\hline $\mathrm{Yb}$ & 2,82 & 0,19 & 0,22 & 0,49 & 0,24 & 0,21 & 4,47 \\
\hline $\mathrm{Lu}$ & 0,433 & 0,18 & 0,21 & 0,50 & 0,24 & 0,21 & 6,24 \\
\hline
\end{tabular}

* média da concentração de ETR de 23 folhelhos pós-arqueanos da Austrália (MCLENNAN, 1989).

** média da concentração de ETR normalizada para diversos fosforitos (ALTSCHULER, 1980).

Tabela 8.4.3 - Anomalias de Ce, Eu e Pr e relações entre ETR.

\begin{tabular}{|c|c|c|c|c|c|c|c|}
\hline Amostras & $F R-A_{n}$ & $F R-B_{n}$ & FR-24n & FR-22 $n$ & FR-22a $a_{n}$ & FR-22 $Q_{n}$ & FR-22 SQ \\
\hline $\mathrm{Ce}_{\text {anomalia }}{ }^{1}$ & 0,035 & 0,119 & 0,129 & 0,074 & 0,077 & 0,038 & 0,048 \\
\hline $\mathrm{Ce} / \mathrm{Ce}^{*^{2}}$ & 1,085 & 1,317 & 1,347 & 1,185 & 1,194 & 1,092 & 1,116 \\
\hline $\mathrm{Eu}_{\text {anomalia }}{ }^{3}$ & $-0,051$ & $-0,043$ & $-0,067$ & $-0,019$ & $-0,022$ & $-0,041$ & 0,026 \\
\hline $\mathrm{Eu} / \mathrm{Eu}^{*} 4$ & 0,285 & 0,272 & 0,365 & 0,352 & 0,339 & 0,297 & 0,377 \\
\hline
\end{tabular}

1) $\mathrm{Ce}_{\text {anomalia }}=\log \left[3 \mathrm{Ce}_{\mathrm{n}} /\left(2 \mathrm{La}_{\mathrm{n}}+\mathrm{Nd}_{\mathrm{n}}\right)\right]$ (ELDERFIELD; GREAVES, 1982);

2) $\mathrm{Ce} / \mathrm{Ce}^{*}=3 \mathrm{Ce}_{n} /\left(2 \mathrm{La}_{\mathrm{n}}+\mathrm{Nd}_{n}\right)$ (SHIELDS; STILLE, 2001);

3) $E u_{\text {anomalia }}=\log \left[2 \mathrm{Eu}_{n} /\left(\mathrm{Sm}_{\mathrm{n}}+\mathrm{Gd}_{\mathrm{n}}\right)\right]$ (ELDERFIELD; GREAVES, 1982);

4) $\mathrm{Eu} / \mathrm{Eu}^{*}=\mathrm{Eu}_{n} /\left(\mathrm{Sm}_{\mathrm{n}}+\mathrm{Gd}_{n}\right)^{0,5}$ (SHIELDS; STILLE, 2001; CHEN et al., 2003). 


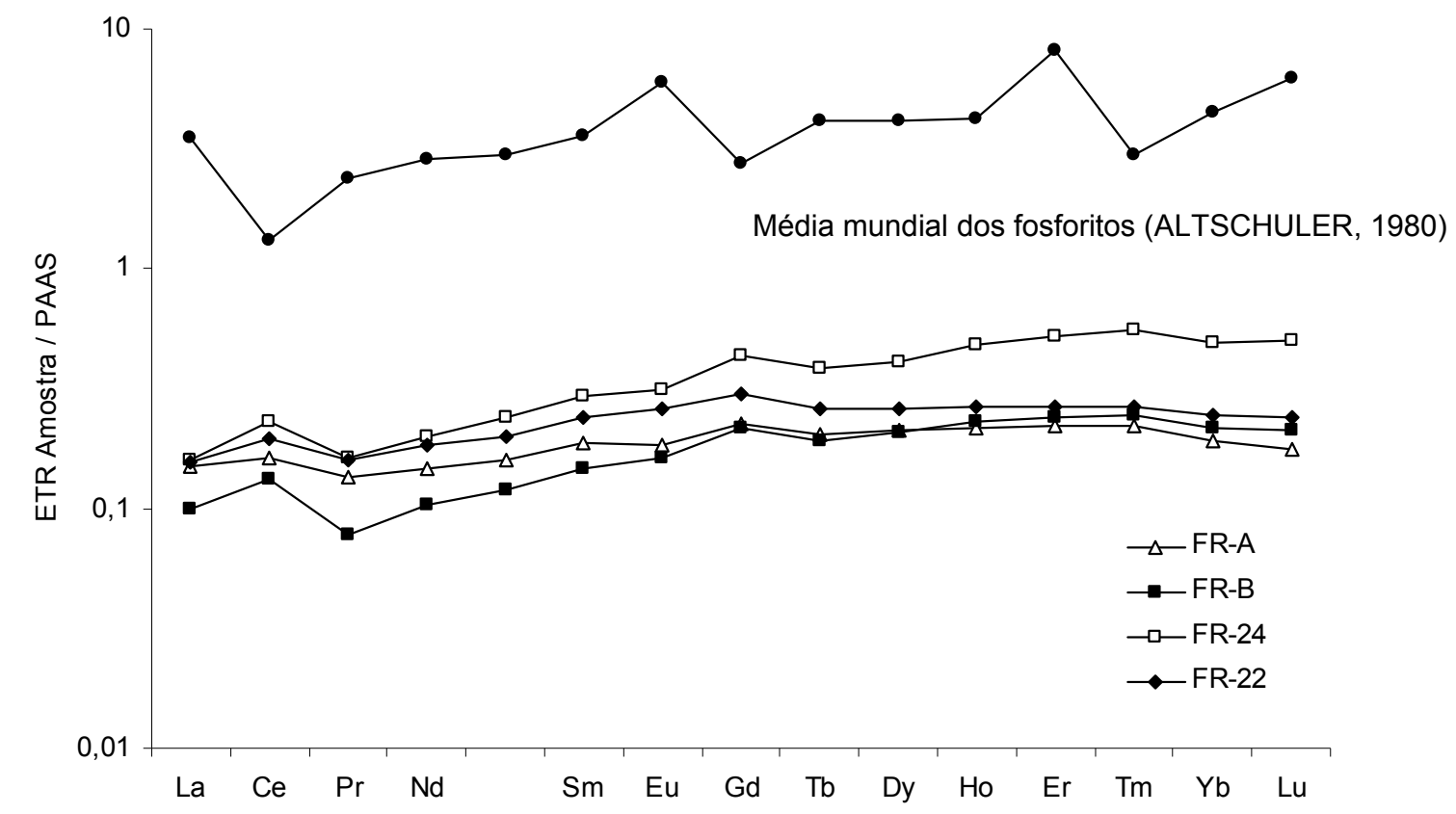

Figura 8.4.1 - Curva de distribuição de ETR para fosforitos da Fazenda Ressaca, concentrações normalizadas para o folhelho PAAS.

Para as amostras de fosforitos da Formação Bocaina, observam-se curvas regulares (Figura 8.4.1), com leve anomalia positiva de $\mathrm{Ce}$, e suave enriquecimento em ETR pesados. Para o elemento Eu não é observada nenhuma anomalia significativa, como observado na curva de valores médios de fosforitos (ALTSCHULER, 1980), na qual chama a atenção a presença de anomalia negativa de $\mathrm{Ce}$, ao contrário do observado para as amostras analisadas na presente dissertação.

As anomalias de Ce para os fosforitos da Fazenda Ressaca variam entre $\mathrm{Ce}_{\text {anomalia }}=$ 0,035 e 0,129 (ELDERFIELD; GREAVES, 1982) e Ce/Ce ${ }^{*}=1,085$ e 1,317 (SHIELDS; STILLE, 2001) (Tabela 8.4.3). Esses valores podem ser considerados positivamente anômalos, pois são superiores a -0,10 (WRIGHT et al., 1987).

As anomalias positivas de Ce são interpretadas como produto de águas pouco oxigenadas (SHIELDS; STILLE, 2001) e até relacionadas à paleo-oceanos estratificados (MAZUMDAR et al., 1999b), como discutido no capítulo 5.

Neste presente estudo, interpreta-se que os fosforitos da Fazenda Ressaca foram formados na eodiagênese, em condições geoquímicas redutoras, indicada pela assinatura de ETR, o que permitiu a preservação da matéria orgânica, na interface da zona vadosa e freática, durante momentos de nível do mar alto ou em ascensão. 


\section{GÊNESE DE DOLOMITOS E FOSFORITOS DA FORMAÇÃO BOCAINA}

No trabalho de Boggiani (1998), a Formação Bocaina foi interpretada como uma plataforma carbonática rasa, depositada sob superfície aplainada, a partir da entrada da água do mar, cujas condições paleoambientais permitiram o desenvolvimento de estromatólitos. A origem dos dolomitos foi interpretada como secundária, devido à percolação de fluidos meteóricos, em zona de mistura de água do mar e água doce.

Para os fosforitos, o modelo genético, originalmente proposto por Boggiani (1990), foi o modelo clássico de ressurgências marinhas (Figura 3.3.4), com nível de mar alto ou em ascensão, no qual as rochas fosfáticas representariam um marco estratigráfico na bacia (hardground), relacionado a evento de máxima transgressão (BOGGIANI, 1998).

Neste presente trabalho, a partir das evidências geoquímicas e petrográficas, propõem-se modelos alternativos, tanto para a gênese dos dolomitos quanto dos fosforitos.

A associação das fácies carbonáticas (capítulo 7), que inclui grainstones oolíticos, com estratificações cruzadas, configurando bancos oolíticos, apontam para um ambiente de águas rasas bem oxigenadas e agitadas, e boundstones pseudo-colunares, com oncóides, variando para esteiras microbianas, indicam águas mais rasas com energia moderada, no qual haveria intensa proliferação microbiana. As fácies sedimentares somadas às estruturas do tipo tepee (Figura 7.2.8), que indicam exposição subaérea, sugerem ambiente de supramars até inframaré para a formação destes sedimentos.

Os grãos revestidos de laminação irregular foram interpretados como vadóides, que são um tipo específico de pisóides formados na zona vadosa, econtrados nos mais diversos ambientes, desde lacustres, fluviais, marinhos até pedogenéticos, e são originados por acreção de lâminas minerais bioinduzida.

Nas amostras estudadas de grainstones pisolíticos, observa-se cimento em franja (Figura 7.1.20), típico de zona vadosa, além de porções da matriz micrítica englobada nas laminações dos grãos revestidos (Figura 7.1.19), o que seria indicativo de grão formado em subsuperfície. Além dessas indicações, macroscopicamente observa-se que os grãos não se tocam (Figura 7.1.11), configurando mais uma evidência de que foram formados abaixo da interface sedimento/água.

As fácies sedimentares observadas na Formação Bocaina são encontradas desde ambientes sedimentares marinhos a continentais, no entanto, considerando o contexto da Bacia Corumbá e sua evolução, acredita-se que a interpretação de uma laguna seja mais coerente para as rochas da Formação Bocaina, já que estaria inserida em um contexto de subida do nível do mar sobre superfície aplainada, propícia para a geração de bacias rasas. A Figura 9.1 ilustra o paleoambiente lagunar da Formação Bocaina, cuja conexão com o mar 
aberto se daria na forma de complexos de canais de marés, assim como atualmente é observado nas Bahamas. A dinâmica destes canais permitiria a rápida sucessão lateral e vertical das fácies sedimentares, uma característica da Formação Bocaina.

Subseqüentemente, ocorre o conglomerado polimítico, interpretada como a base de um talude, e os calcários marinhos da Formação Tamengo além dos folhelhos da Formação Guaicurus (BOGGIANI, 1998).

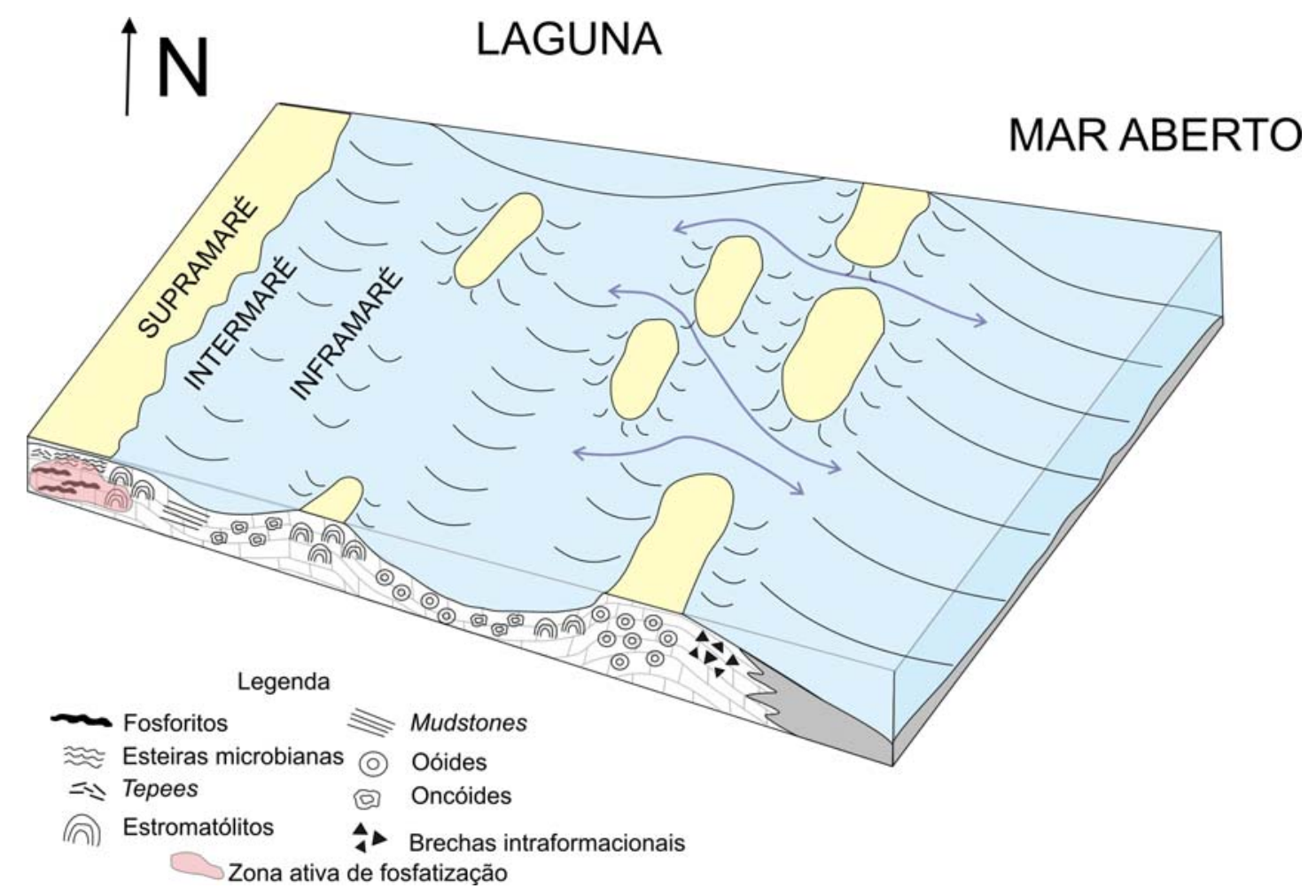

Figura 9.1 - Bloco diagrama esquemático representando um possível modelo de distribuição das fácies sedimentares da Formação Bocaina, no ambiente lagunar com conexões restritas ao mar aberto (complexo de canais de marés). Neste esquema, também é representada a zona ativa de fosfogênese.

Considerando o ambiente lagunar, para a gênese dos dolomitos e fosforitos há duas vertentes interpretativas possíveis e que não podem ser descartadas:

1. A gênese dos dolomitos e fosforitos estão associadas: o processo biogeoquímico responsável pela precipitação da dolomita e da apatita é a metanogênese, tendo em vista o ligeiro sinal positivo de $\delta^{13} \mathrm{C}_{\mathrm{VPDB}}(0,95$ e $3,15 \%)$. O processo de sulfato-redução é descartado já que não apresenta valores negativos, característicos do processo, nem expressiva concentração de pirita nestas amostras. Nesta hipótese tanto a dolomita como a apatita são formadas na eodiagênese, por bioindução. 
Apesar de a metanogênese ser um dos processos apontado como formador de dolomita em ambiente sedimentar rico em matéria orgânica (BURNS; BAKER, 1987; MAZZULLO, 2000; WRIGHT, 2000) não há análogos modernos nos quais a metanogênese seja comprovada experimentalmente. A dolomita primária precipitada atualmente nas lagoas hipersalinas, como a Lagoa Vermelha, é relacionada apenas a sulfato-redução (VASCONCELOS; MCKENZIE, 1997; VASCONCELOS et al., 2006). Acredita-se que na Lagoa Salgada, também no norte do estado fluminense, possa ocorrer dolomita primária originada por metanogênese, baseado no sinal isotópico de $\delta^{13} \mathrm{C}_{\mathrm{PDB}}$ obtido para esses sedimentos, em média entre 10 e 20\% (LUNDBERG et al., 2009; VASCONCELOS et al., 2009), porém o processo biogeoquímico não foi demonstrado e quantificado por experimentos laboratoriais.

2. A gênese de dolomitos e fosforitos não está diretamente relacionada. Nesta hipótese primeiramente haveria a formação de lâminas de aragonita ou calcita cujos cristais foram precipitados e/ou aprisionados nas esteiras microbianas e grãos pisolíticos, intercalados às lâminas de matéria orgânica. Da mesma forma, os oóides foram inicialmente precipitados como de carbonato de cálcio.

$\mathrm{Na}$ eodiagênese, a matéria orgânica é degradada, permitindo a precipitação da apatita, provavelmente bioinduzida (SOUDRY; CHAMPETIER, 1983; LUCAS; PRÉVÔT, 1985; RAO et al., 1992; COMPTON et al., 1993) em ambiente geoquímico redutor, como demostrado por Pufahl \& Grimm (2003). Ainda na eodiagênese as lâminas de carbonato de cálcio foram convertidas para dolomita, devido a intensa taxa de evaporação e refluxo das águas oceânicas, ricas em Mg (TUCKER; WRIGHT, 1990).

Considera-se que a segunda hipótese é mais provável de ter ocorrido para os dolomitos e fosforitos da Formação Bocaina, tendo em vista que os cristais de dolomita em todas as fácies sedimentares estudadas neste trabalho apresentam-se límpidos e não exibem morfologia arredondada, nem dimensões adequadas, não se pode afirmar que foram bioinduzidas.

Grande parte das dolomitas estudadas, apesar de preservarem as estruturas sedimentares originais, apresenta feições de dolomitização mais tardia. Essa constatação remete a outro raciocínio: de que as dolomitas poderiam ser primárias, formadas por bioindução, e na mesodiagênese foram substituídas por dolomitas tardias por processos de recritalização que não obliteraram as estruturas sedimentares. No entanto, essa hipótese não poderia ser comprovada.

Considerando que os fosforitos foram originados a partir da degradação da matéria orgânica em lâminas preferencialmente enriquecidas, como no caso dos pisólitos ou na 
própria esteira microbiana (fosfalutito com laminação microbiana), as anomalias positivas de Ce sugerem ambiente geoquímico redutor para precipitação da apatita, durante a eodiagênese.

A fosfogênese, como descrito na literatura, ocorre preferencialmente em momentos de nível de mar alto, compreendendo muitas vezes superfícies de máxima transgressão (RAO et al., 1992; FÖLLMI, 1996; PUFAHL; GRIMM, 2003). Como todas as fácies da Formação Bocaina indicam ambientes de águas rasas, não se espera encontrar um hardground fosfático nem a associação com fácies pelíticas distais ou mesmo glauconita, no entanto, a fosfatização indica esse momento, da mesma forma que Pufhal \& Grimm (2003) interpretam que grãos revestidos de apatita, formados na eodiagênese durante longos períodos de residência, configuram correlatos de superfícies condensadas.

Já a fácies de fosfarenito (Figuras 7.1.31, 7.1.32 e 7.1.33) indica que o material fosfático foi retrabalhado rapidamente após sua formação, evidenciada pela presença de cimento de apatita eodiagenético (Figura 7.1.32). Isso indica que após a máxima transgressão, registrada pelo evento de fosfogênese na bacia, houve uma queda do nível do mar, e rápido retrabalhamento dos sedimentos previamente formados. Esse rebaixamento fica evidente no conglomerado polimítico, sobrejacente ao nível fosfático, que constituem a base da Formação Tamengo.

As evidências de estruturas tipo tepees e os pseudomorfos de cristais de gipso são fortes indicadores de paleoclima quente e árido no momento da deposição da Formação Bocaina. 


\section{CONCLUSÕES}

A Formação Bocaina, Grupo Corumbá, de idade ediacarana, é composta essencialmente de dolomitos com abundantes estruturas microbianas e rochas fosfáticas sedimentares no topo da sucessão sedimentar.

Observações de campo e ao microscópio petrográfico das duas principais seções colunares levantadas, próximo a Bonito (Fazenda Ressaca) e a Corumbá (Morro do Bugio), bem como o afloramento de Porto Morrinhos, permitiram individualizar fácies sedimentares constituídas por grainstones oolíticos, pisolíticos, mudstones, boundstones (estromatólitos colunares, pseudo-colunares ou em forma de esteiras microbianas) e brechas intraformacionais com estruturas tepees.

Estas observações, somadas ao contexto da Bacia Corumbá, apontam para um paleoambiente lagunar raso (Figura 9.1), com conexões restritas (complexo de canais) ao mar aberto. Pelo mapa de localização de afloramentos (Anexo B), é possível visualizar que a laguna teria disposição NW-SE, incluindo os municípios de Bonito e Corumbá, o que confere uma extensão superior a $200 \mathrm{~km}$ de comprimento. O paleo-oceano estaria a leste, como sugerido por Boggiani (1998).

A porção NW deste corpo d'água, representada pela seção do Morro do Bugio, Corumbá, estaria freqüentemente sujeito a ressecamento e exposição subaérea, evidenciado pela abundância de fácies de brechas intraformacionais, com estruturas tepees, bem como maior aporte de sedimentos terrígenos, devido à maior quantidade de grãos de quartzo, em geral bem arredondados, dispersos em meio à matriz dolomítica. Na borda NW também se observa maior quantidade de oóides, muito bem preservados devido à silicificação, indicando águas agitadas e rasas. Já a borda SE da laguna, representada pela seção da Fazenda Ressaca, deveria ser rasa também, porém menos exposta a ressecamento, já que nela observa-se maior abundância de estromatólitos colunares e esteiras microbianas.

As evidências de estruturas tipo tepees e os pseudomorfos de cristais de gipso são indicadores de condições evaporíticas durante a deposição da Formação Bocaina.

Para a gênese dos dolomitos da Formação Bocaina, neste trabalho, são apresentadas fundamentalmente duas propostas: (1) os dolomitos são primários, formados por bioindução em sedimentos ricos em matéria orgânica, por processos de metanogênese e (2) os dolomitos são secundários, formados por substituição de calcita ou aragonita na eodiagênese, pela elevada taxa de evaporação e refluxo das águas oceânicas, ricas em Mg.

A primeira hipótese é sustentada fragilmente nos dados de isótopo de carbono obtidos nesse trabalho, que são ligeiramente positivos $(0,95$ e $3,15 \%$ ), e poderia sugerir 
pequena contribuição de metanogênese na formação destes dolomitos. No entanto, valores francamente associados à metanogênese são extremamente positivos (acima de $+10 \%$ ), e petrograficamente os dolomitos microbianos exibem cristais muito finos de dolomita e em geral com aspecto turvo, contrariamente ao observado para os dolomitos da Formação Bocaina. Para se comprovar esta hipótese, sugere-se fazer uma estratigrafia química de detalhe, com isótopos de $\mathrm{C}$ e $\mathrm{O}$ em mais amostras e análise de COT, para saber se essas amostras contem carbono orgânico suficiente para gerar dolomitos organogênicos.

A segunda hipótese é mais provável de ter ocorrido, pois há diversas evidências de exposição subaérea, que permitiria a dolomitização dos sedimentos calcíticos, por refluxo das águas oceânicas ricas em Mg. A textura xenotópica da maioria dos cristais de dolomita indica que foram formados na diagênese.

Uma terceira hipótese, pouco provável, mas que não pode ser descartada, apesar de difícil comprovação, é de que os dolomitos da Formação Bocaina são primários, mas na diagênese foram convertidos para dolomitas tardias, que não obliterou as estruturas primárias.

Para a gênese dos fosforitos há também duas possibilidades: (1) os fosforitos formaram-se contemporaneamente aos dolomitos ou (2) os fosforitos formaram-se diacronicamente aos dolomitos. A primeira hipótese assume que ambas as rochas são bioinduzidas. Para os dolomitos esta proposição já foi argumentada. A segunda hipótese é considerada mais provável, assumindo que a origem dos dolomitos secundária.

Assim, acredita-se que foram gerados na eodiagênese em sedimentos ricos em matéria orgânica, a qual seria responsável por disponibilizar fósforo para as águas intersticiais. As condições geoquímicas redutoras, corroborada pela anomalia positiva de Ce, permitiram a precipitação de apatita com provável contribuição de bioindução, evidenciada pela morfologia dos cristais e agregados de fosfato ao MEV.

As fácies de fosfalutito estratificado (esteiras microbianas fosfatizadas) e fosforito "alongado" (oncóides fosfáticos ou fosfatizados), bem como os níveis fosfatizados nos dolomitos pisolíticos, indicam máxima transgressão, representada por uma superfície condensada.

A fácies de fosfarenito indica que os fosforitos foram retrabalhados, sendo que este retrabalhamento estaria associado ao rebaixamento do nível do mar, que é tipicamente representado pela presença do conglomerado polimítico da base da Formação Tamengo, encontrada desde Bonito a Corumbá, marcando a borda do paleo-talude. As fácies de calcários marinhos que se sobrepõe ao conglomerado indicam o fim do ambiente lagunar restrito, representado pela Formação Bocaina, e instalação de um ambiente francamente marinho. 


\section{REFERÊNCIAS BIBLIOGRÁFICAS}

ALMEIDA, F.; MANTOVANI, M. Geologia e geocronologia do Granito São Vicente, Mato Grosso. Anais da Academia Brasileira de Ciências, v.47, p.451-458, 1975.

ALMEIDA, F. F. M. Geologia do Sudoeste Mato-Grossense. Boletim da Divisão de Geologia e Mineralogia, DNPM, Boletim 116, 1945. 118p.

ALMEIDA, F. F. M. Geologia da Serra da Bodoquena (Mato Grosso), Brasil. Boletim da Divisão de Geologia e Mineralogia, DNPM, Boletim 219, 1965. 96p.

ALMEIDA, F. F. M. Província Tocantins - setor sudoeste. In: ALMEIDA, F. F. M.; HASUI, Y. (Ed.). O Pré-Cambriano do Brasil. São Paulo: Blücher, 1984, p.265-281.

ALTSCHULER, Z. S. The geochemistry of trace elements in marine phosphorites: Part 1. Characteristic abundances and enrichment. In: BENTOR, Y. K. (Ed.). Marine Phosphorites. Oklahoma, USA: The Society of Sedimentary Geology, 1980, v.29, p.19-30.

ALVARENGA, C.; SANTOS, R.; DANTAS, E. CO-Sr isotopic stratigraphy of cap carbonates overlying Marinoan-age glacial diamictites in the Paraguay Belt, Brazil. Precambrian Research, v.131, n.1-2, p.1-21, 2004.

ALVARENGA, C.; TROMPETTE, R. Glacially influenced sedimentation in the Later Proterozoic of the Paraguay belt (Mato Grosso, Brazil). Palaeogeography, Palaeoclimatology, Palaeoecology, v.92, n.1-2, p.85-105, 1992.

ALVARENGA, C.; TROMPETTE, R. Evolução Tectônica brasiliana da Faixa Paraguai: A estruturação da região de Cuiabá. Revista Brasileira de Geociências, v.23, p.18-30, 1993.

AMARAL, A. J. R. Geologia do Fosfato. In: SCHOBBENHAUS, C.; QUEIROZ, E. T.; COELHO, C. E. S. (Ed.). Principais Depósitos Minerais Brasileiros. Brasília: DNPM/CPRM, 1997, v.IV, Rochas e Minerais Brasileiros, p.643.

ASSERETO, R.; KENDALL, C. G. Nature, origin and classification of peritidal tepee structures and related breccias. Sedimentology, v.24, n.2, p.153-210, 1977.

BABINSKI, M.; TRINDADE, R.; ALVARENGA, C.; BOGGIANI, P.; LIU, D.; SANTOS, R.; BRITO NEVES, B. Chronology of Neoproterozoic ice ages in central Brazil. In: V South American Symposium on Isotope Geology, 2006, Punta del Este, Uruguay. 2006, p.303-306.

BAKER, P.; KASTNER, M. Constraints on the formation of sedimentary dolomite. Science, v.213, n.214-216, 1981.

BATURIN, G. N. Phosphorus Cycle in the Ocean. Lithology and Mineral Resources, v.38, n.2, p.101-119, 2003. 
BERNER, R. A. A atmospheric carbon dioxide levels over Phanerozoic time. Science, v.249, p.1382-1386, 1990.

BOGGIANI, P. C. Ambientes de sedimentação do Grupo Corumbá na região central da Serra da Bodoquena, Mato Grosso do Sul. 1990. 91p. (Dissertação de Mestrado) - Instituto de Geociências, Universidade de São Paulo, São Paulo, 1990.

BOGGIANI, P. C. Análise Estratigráfica da Bacia Corumbá (Neoproterozóico), Mato Grosso do Sul. 1998. 181p. (Tese de Doutorado) - Instituto de Geociências, Universidade de São Paulo, São Paulo, 1998.

BOGGIANI, P. C.; ALVARENGA, C. J. S. Faixa Paraguai. In: MANTESSO-NETO, V.; BARTORELLI, A.; CARNEIRO, A. D. R.; BRITO-NEVES, B. B. (Ed.). Geologia do Continente Sul-Americano: Evolução da Obra de Fernando Flávio Marques de Almeida. São Paulo: Beca Editora, 2004, p.113-122.

BOGGIANI, P. C.; BABINSKI, M.; YAMAMOTO, J. K.; FAIRCHILD, T. R.; RICCOMINI, C.; DIRATGITCH, A. A.; LIU, D. U-Pb SHRIMP investigation of ash beds in the Corumbá Group (Ediacaran), Paraguay Belt, Brazil. In: 2 Symposium on Neoproterozoic - Early Palaeozoic Events in southwestern Gondwana, 2005, Windhoek - Namibia. Abstracts, IGCP-478, 2005, 2, p.8-9.

BOGGIANI, P. C.; COIMBRA, A. M. Quaternary limestone of Pantanal area, Brazil. Anais da Academia Brasileira de Ciências, v.67, n.3, p.343-349, 1995.

BOGGIANI, P. C.; FAIRCHILD, T. R.; COIMBRA, A. M. O Grupo Corumbá (Neoproterozóico-Cambriano) na região Central da Serra da Bodoquena, Mato Grosso do Sul (Faixa Paraguai). Revista Brasileira de Geociências, v.23, n.3, p.301305, 1993.

BOGGIANI, P. C.; GAUCHER, C.; SIAL, A. N.; BABINSKI, M.; SIMON, C. M.; RICCOMINI, C.; FERREIRA, V. P.; FAIRCHILD, T. R. Chemostratigraphy of theTamengo Formation (Corumbá Group, Brazil): A contribution to the calibration of the Ediacaran carbon-isotope curve. Precambrian Research, v.182, p.382-401, 2010.

BONTOGNALI, T. R. R.; VASCONCELOS, C.; WARTHMANN, R. J.; BERNASCONI, S. M.; DUPRAZ, C.; STROHMENGER, C. J.; MCKENZIE, J. A. Dolomite formation within microbial mats in the coastal sabkha of Abu Dhabi (United Arab Emirates). Sedimentology, v.57, n.3, p.824-844, 2010.

BURNS, S.; BAKER, P. A geochemical study of dolomite in the Monterey Formation, California. Journal of Sedimentary Petrology, v.57, n.1, p.128-139, 1987.

CAMPANHA, G. A. C.; BOGGIANI, P. C.; SALLUN FILHO, W.; DE SÁ, F. R.; ZUQUIM, M. P. S.; PIACENTINI, T. A faixa de dobramento Paraguai na Serra da Bodoquena e depressão do Rio Miranda, Mato Grosso do Sul. Geologia USP - Série Científica, v.11, p.79-96, 2011. 
CARMINATTI, M.; DIAS, J.; WOLFF, B. From Turbidites to Carbonates: Breaking Paradigms in Deep Waters. In: Offshore Technology Conference, 2009, Houston, Texas, USA. 2009.

CASTELNAU, F. D. Expedition dans les parties centrales de l"Amerique du Sud, etc. Paris: 15 volumes em 7 partes, 1857.

CHEN, D. F.; DONG, W. Q.; QI, L.; CHEN, G. Q.; CHEN, X. P. Possible REE constraints on the depositional and diagenetic environment of Doushantuo Formation phosphorites containing the earliest metazoan fauna. Chemical Geology, v.201, n.1-2, p.103-118, 2003.

COMPTON, J.; HALL, D.; MALLINSON, D.; HODELL, D. Origin of dolomite in the phosphatic Miocene Hawthorn Group of Florida. Journal of Sedimentary Research, v.64, n.3, p.638-649, 1994.

COMPTON, J. S.; HODELL, D. A.; GARRIDO, J. R.; MALLINSON, D. J. Origin and age of phosphorite from the south-central Florida Platform: Relation of phosphogenesis to sea-level fluctuations and [delta] $13 \mathrm{C}$ excursions. Geochimica et Cosmochimica Acta, v.57, n.1, p.131-146, 1993.

COOK, P. J.; MCELHINNY, M. W. A reevaluation of the spatial and temporal distribution of sedimentary phosphate deposits in the light of plate tectonics. Economic Geology, v.74, n.2, p.315-330, 1979.

COOK, P. J.; SHERGOLD, J. H. Phosphorus, phosphorites and skeletal evolution at the Precambrian-Cambrian boundary. Nature, v.308, p.231-236, 1984.

CORSETTI, F. A.; KIDDER, D. L.; MARENCO, P. J. Trends in oolite dolomitization across the Neoproterozoic-Cambrian boundary: A case study from Death Valley, California. Sedimentary Geology, v.191, n.3-4, p.135-150, 2006.

DANTAS, E.; ALVARENGA, C.; SANTOS, R.; PIMENTEL, M. Using Nd isotopes to understand the provenance of sedimentary rocks from a continental margin to a foreland basin in the Neoproterozoic Paraguay Belt, central Brazil. Precambrian Research, v.170, n.1-2, p.1-12, 2009.

DARDENNE, M. A.; SILVA-FREITAS, F. H.; SANTOS, G. M.; SOUZA, J. F. C. Depósitos de fosfato de Rocinha e Lagamar, Minas Gerais. In: SCHOBBENHAUS, C.; QUEIROZ, E. T.; COELHO, C. E. S. (Ed.). Principais Depósitos Minerais Brasileiros. Brasília: DNPM/CPRM, 1997, v.IV, Rochas e Minerais Brasileiros, p.634.

DAVIS, R. A. Depositional systems. New Jersey: Prentice-Hall Englewood Cliffs, 1983. 669p.

DE DOLOMIEU, D. Sur un genre de pierres calcaires trespeu effervescentes avec les acides et phosphorescentes par la collision. J. Physique, v.39, p. 3-10, 1791. 
DORR II, J. V. N. Manganese and iron deposits of Morro do Urucum, Mato Grosso, Brazil. Geological Survey Bulletin, v.946-A, p.1-47, 1945.

DUARTE, E. W.; KRAUSS, L. A. A. S. Projeto de Dimensionamento das Jazidas de Fosfato de Pernambuco. Recife: CONDEPE, Governo do Estado de Pernambuco, 1978. 32p.

DUNHAM, R. J. Classification of carbonate rocks according to depositional texture. In: HAM, W. E. (Ed.). Classification of carbonate rocks. Tulsa, Oklahoma: American Association of Petroleum Geologists Memoir, 1962, p.108-121.

ELDERFIELD, H.; GREAVES, M. J. The rare earth elements in seawater. Nature, v.296, n.5854, p.214-219, 1982.

EMBRY, A. F.; KLOVAN, J. E. A late Devonian reef tract on northeastern Banks Island, N.W.T. Bulletin of Canadian Petroleum Geology, v.19, n.4, p.730-781, 1971.

EVANS, J. W. The geology of Mato Grosso. Quartely Journal of the Geological Society of London, v.50, n.2, p.85-104, 1894.

FISSEHA, S. Estruturas geoelétricas crustais do Pantanal e Faixa Paraguai: implicações tectônicas. Revista Brasileira de Geofísica, v.22, p.183-183, 2004.

FOLK, R. L. Pratical petrographic classification of limestones. Bulletin of American Association of Petroleum Geologists, v.43, p.1-38, 1959.

FÖLLMI, K. B. The phosphorus cycle, phosphogenesis and marine phosphate-rich deposit. Earth-Science Reviews, Zurique, v.40, p.55-124, 1996.

FREIRE, R. C. Modelagem Geométrica Tridimensional da Seqüência Metassedimentar de Itataia, CE. In: $2^{\circ}$ CONGRESSO BRASILEIRO DE P\&D EM PETRÓLEO E GÁS, 2003, Rio de Janeiro. 2003.

FREITAS, B. T. Tectônica e sedimentação do Grupo Jacadigo (Neoproterozóico, MS). 2010. 144p. (Dissertação de Mestrado) - Universidade de São Paulo, São Paulo, 2010.

FRIEDMAN, G. M. Identification of carbonate minerals by staining methods. Journal of Sedimentary Research, v.29, n.1, p.87-97, 1959.

FRIEDMAN, G. M.; SANDERS, J. E. Principles of sedimentology. New York: John Wiley \& Sons, 1978. 792p.

GAUCHER, C.; BOGGIANI , P. C.; SPRECHMANN, P.; SIAL, A. N.; FAIRCHILD, T. R. Integrated correlation of Vendian to Cambrian Arroyo del Soldado and Corumbá Groups (Uruguay and Brazil): palaeogeographic, palaeoclimatic and palaeobiologic implactions. Precambrian Research, v.120, n.3-4, p.241-278, 2003. 
GEBELEIN, C. D.; HOFFMAN, P. F. Algal origin of dolomite laminations in stromatolite limestones. Journal of Sedimentary Petrology, v.43, p.603-613, 1973.

GIVEN, R. K.; WILKINSON, B. H. Dolomite abundance and stratigraphic age: constraints on rates and mechanisms of Phanerozoic dolostone formation. Journal of Sedimentary Petrology, v.57, p.1068-1078, 1987.

GLENN, C. R. Pore water, petrologic and stable carbon isotopic data bearing on the origin of Modern Peru margin phosphorites and associated authigenic phases. In: BURNETT, W. C.; RIGGS, S. R. (Ed.). Neogene to Modern Phosphorites: Phosphate Deposits of the World. Cambridge: Cambridge University Press, 1990, v.3, p.46-62.

GROTZINGER, J. P.; ROTHMAN, D. H. An abiotic model for stromatolite morphogenesis. Nature, v.383, n.6599, p.423-425, 1996.

HAIDINGER, W. Ueber die Pseudomorphosen und ihre anogene und katogene Bildung. Abh. K. bo"hm. Ges. Wiss.Prague, Ser., v.5, n.3, p.231-259, 1845.

HOEFS, J. Stable isotope geochemistry. Springer Verlag, 2009. 285p.

HOLSER, W. T. Evaluation of the application of rare-earth elements to paleoceanography. Palaeogeography, Palaeoclimatology, Palaeoecology, v.132, p.309-323, 1997.

ILYIN, A. V. Rare-earth geochemistry of 'old' phosphorites and probability of syngenetic precipitation and accumulation of phosphate. Chemical Geology, v.144, n.3-4, p.243-256, 1998.

JUSTO, L. J. E. C. Fosfato da Serra da Bodoquena - Mato Grosso do Sul. Goiânia, GO: Programa de Avaliação Geológico-Econômica de Insumos Minerais para Agricultura no Brasil, CPRM, 2000. 31p.

KAZAKOV, A. V. The phosphate facies: origin of the phosphorite and the geologic factors of formations of the deposits. Proc. Sci. Inst. Fertilizers and Insectofungicides, v.145, n.1-106, 1937.

KENDALL, C.; WARREN, J. A review of the origin and setting of tepees and their associated fabrics. Sedimentology, v.34, n.6, p.1007-1027, 1987.

KHOLODOV, V. N. Geochemistry of Phosphorus and Origin of Phosphorites: Communication 1. Role of Terrigenous Material in the Hypergene Phosphorus Geochemistry. Lithology and Mineral Resources, v.38, n.4, p.314-331, 2003a.

KHOLODOV, V. N. Geochemistry of Phosphorus and Origin of Phosphorites: Communication 2. Sources of Phosphorus in Continents and Genesis of Marine Phosphorites. Lithology and Mineral Resources, v.38, n.6, p.477-495, 2003b. 
LEIGHTON, M. W.; PENDEXTER, C. Carbonate rock types. In: HAM, W. E. (Ed.). Classification of Carbonate rocks: a symposium. Tulsa, Oklahoma: AAPG, 1962, p.33-61.

LIPMANN, F. Sedimentary Carbonate Minerals. Berlin Spinger-Verlag, 1973. 228p.

LOGAN, B. W.; REZAK, R.; GINSBURG, R. N. Classification and environmental significance of algal stromatolites. Journal of Geology, v.72, p.68-83, 1964.

LUCAS, J.; PRÉVÔT, L. The synthesis of apatite by bacterial activity: mechanism. Sci. Geol. Mem, v.77, p.83-92, 1985.

LUNDBERG, R.; BONTOGNALI, T.; MCKENZIE, J.; VASCONCELOS, C. Modern Stromatolites from Lagoa Salgada, Brazil: Role of Methanogens in Carbonate Precipitation. Geochimica et Cosmochimica Acta Supplement, v.73, p.800, 2009.

LUZ, J. S.; MARQUES, V. J.; ABREU-FILHO, W.; BRANDÃO, I. A.; MELLO, J. C. R. Projeto Fosfato de Bonito. Relatório de prospecção preliminar. Goiânia, GO: CODESUL/CPRM, 1980. 41p.

MACIEL, P. Tilito Cambriano (?) no Estado de Mato Grosso. Boletim da Sociedade Brasileira de Geologia, v.81, p.31-39, 1959.

MACLEOD, K. G.; IRVING, A. J. Correlation of Cerium Anomalies with Indicators of Paleoenvironment. Journal of Sedimentary Research, v.66, n.5, p.948-955, 1996.

MANZANO, J. C.; GODOY, A. M.; ARAÚJO, L. M. B. Contexto tectônico dos granitóides neoproterozóicos da Faixa de Dobramentos Paraguai, MS e MT. Geosciences= Geociências, v.27, n.4, p.493, 2010.

MAZUMDAR, A.; BANERJEE, D. M.; SCHIDLOWSKI, M.; BALARAM, V. Rare-earth elements and Stable Isotope Geochemistry of early Cambrian chert-phosphorite assemblages from the Lower Tal Formation of the Krol Belt (Lesser Himalaya, India). Chemical geology, v.156, n.1, p.275-297, 1999a.

MAZUMDAR, A.; BANERJEE, D. M.; SCHIDLOWSKI, M.; BALARAM, V. Rare-earth elements and Stable Isotope Geochemistry of early Cambrian chert-phosphorite assemblages from the Lower Tal Formation of the Krol Belt (Lesser Himalaya, India). . Chemical Geology, v.156, n.1, p.275-297, 1999b.

MAZZULLO, S. J. Organogenic Dolomitization in Peritidal to Deep-Sea Sediments. Journal of Sedimentary Research, v.70, n.1, p.10-23, 2000.

MCKENZIE, J. A. The dolomite problem: an outstanding controversy. In: MÜLLER, D. W.; MCKENZIE, J. A.; WEISSERT, H. (Ed.). Controversies in Modern Geology. London: Academic Press, 1991, p.37-54. 
MCKENZIE, J. A.; VASCONCELOS, C. Dolomite Mountains and the origin of the dolomite rock of which they mainly consist: historical developments and new perspectives. Sedimentology, v.56, n.1, p.205-219, 2009.

MCLENNAN, S. M. Rare earth elements in sedimentary rocks: influence of provenance and sedimentary processes. . In: LIPIN, B. R., MCKAY, G.A.Ž. (Ed.). Geochemistry and Mineralogy of Rare Earth Elements. Reviews in Mineralogy and Geochemistry, 1989, v.21, p.169-200.

MISI, A.; KAUFMAN, A. J.; VEIZER, J.; POWIS, K.; AZMY, K.; BOGGIANI, P. C.; GAUCHER, C.; TEIXEIRA, J. B. G.; SANCHES, A. L.; IYER, S. S. S. Chemostratigraphic correlation of Neoproterozoic successions in South America. Chemical geology, v.237, n.1-2, p.143-167, 2007.

MISI, A.; KYLE, J. R. Upper Proterozoic carbonate stratigraphy, diagenesis, and stromatolitic phosphorite formation, Irecê Basin, Bahia, Brazil. Journal of Sedimentary Research, v.64, n.2, p.299-310, 1994.

MONTEIRO, M. D.; ANDRADE, A. R. F.; TONIATTI, G. Depósito de fosfato de Irecê, Bahia. In: SCHOBBENHAUS, C.; QUEIROZ, E. T.; COELHO, C. E. S. (Ed.). Principais Depósitos Minerais Brasileiros. Brasília: DNPM/CPRM, 1997, v.IV, Rochas e Minerais Brasileiros, p.634.

MOREIRA, N. F.; WALTER, L. M.; VASCONCELOS, C.; MCKENZIE, J. A.; MCCALL, P. J. Role of sulfide oxidation in dolomitization: Sediment and pore-water geochemistry of a modern hypersaline lagoon system. Geology, v.32, n.8, p.701-704, 2004.

MURRAY, R. W.; BUCHHOLTZ-TEN, M. R.; JONES, D. L.; GERLACH, D. C.; RUSS, G. P. Rare earth elements as indicators of different marine depositional environments in chert and shale. Geology, v.18, p.268-271, 1990.

NADSON, G. A. Beitrag zur Kenntnis der bakteriogenen Kalkablagerungen. Arch. Fuer Hydrobiologie, v.19, p.154-164, 1928.

NOBRE, J.; COIMBRA, A. M. Microfitólitos associados a construções estromatolíticas do Grupo Bambuí, Proterozóiço Superior, na região de Arcos - MG. Revista Brasileira de Geociências, v.30, n.4, p.589-592, 2000.

NOGUEIRA, G. M. S. Enquadramento litoestratigráfico, sedimentologia e evolução geoquímica do deposito fosfático de Lagamar, MG - Formação Vazante, Proterozóico Médio. 1993. 165p. (Dissertação de Mestrado) - Universidade de Brasília, Brasília, 1993.

NOTHOLT, A. J. G.; SHELDON, R. P.; DAVIDSON, D. F. Phosphate Deposits of the World: Phosphate Resources of the World. Cambridge: Cambridge University Press, 1989. v.2, 566p. 
OLIVEIRA, E. C. Tufas Calcárias da Serra da Bodoquena, MS. 2009. 149p. (Dissertação de Mestrado) - Instituto de Geociências da Universidade de São Paulo, São Paulo, 2009.

PAPINEAU, D. Global biogeochemical changes at both ends of the Proterozoic: insights from phosphorites. Astrobiology, v.10, n.2, p.165-181, 2010.

PERYT, T. M. Coated Grains. Berlin: Springer Verlag, 1983. 655p.

PUFAHL, P. K.; GRIMM, K. A. Coated phosphate grains: Proxy for physical, chemical, and ecological changes in seawater. Geology, v.31, n.9, p.801-804, 2003.

RAO, V. P.; LAMBOY, M.; NATARAJAN, R. Possible microbial origin of phosphorites on Error Seamount, northwestern Arabian Sea. Marine Geology, v.106, n.1-2, p.149164, 1992.

RAO, V. P.; MICHARD, A.; NAQVI, S. W. A.; BÖTTCHER, M. E.; KRISHNASWAMY, R.; THAMBAN, M.; NATARAJAN, R.; BOROLE, D. V. Quaternary phosphorites off the southeast coast of India. Chemical geology, v.182, n.2-4, p.483-502, 2002.

REZENDE, N. G. A. M. O Fosfato de Olinda e os Conflitos de Mineração. Recife, PE: MME/CPRM, Superintendência Regional de Recife, 1994. v.3, 19p. Série Recursos Minerais.

SALLUN FILHO, W.; FAIRCHILD, T. R.; BOGGIANI, P. C. Microesferas em fosforitos do Grupo Corumbá (Proterozóico Terminal), Serra da Bodoquena (MS): microfósseis ou estruturas inorgânicas? In: Reunião de Paleobotânicos e Palinólogos 8, 1994, São Paulo. 1994, p.71-72.

SÁNCHEZ-ROMÁN, M.; MCKENZIE, J. A.; DE LUCA REBELLO WAGENER, A.; RIVADENEYRA, M. A.; VASCONCELOS, C. Presence of sulfate does not inhibit lowtemperature dolomite precipitation. Earth and Planetary Science Letters, v.285, n.1-2, p.131-139, 2009.

SÁNCHEZ-ROMÁN, M.; RIVADENEYRA, M. A.; VASCONCELOS, C.; MCKENZIE, J. A. Biomineralization of carbonate and phosphate by moderately halophilic bacteria. FEMS Microbiology Ecology, v.61, n.2, p.273-284, 2007.

SCHOPF, J. W. Earth's earliest biosphere: its origin and evolution. Princeton, NJ, USA: Princeton University Press, 1983. 565p.

SCHWENNICKE, T.; SIEGMUND, H.; JEHL, C. Marine phosphogenesis in shallowwater environments: Cambrian, Tertiary, and Recent examples. In: GLENN, C. R.; PRÉVÔT-LUCAS, L.; LUCAS, J. (Ed.). Marine Authigenesis: From Global to Microbial. Tulsa, Oklahoma: SEPM Special Publication, 2000, p.481-498.

SEMIKHATOV, M.; GEBELEIN, C.; CLOUD, P.; AWRAMIK, S.; BENMORE, W. Stromatolite morphogenesis- progress and problems. Canadian Journal of Earth Sciences, v.16, p.992-1015, 1979. 
SHARP, Z. Principles of stable isotope geochemistry. Pearson Education Upper Saddle River, NY, 2007. 487p.

SHELDON, R. P. Ancient Marine Phosphorites. Annual Review of Earth and Planetary Sciences, v.9, n.1, p.251-284, 1981.

SHIELDS, G.; STILLE, P. Diagenetic constraints on the use of cerium anomalies as paleoseawater redox proxies: an isotopic and REE study of Cambrian phosphorites. Chemical Geology, v.175, n.1-2, p.29-48, 2001.

SHIELDS, G.; STILLE, P.; BRASIER, M. D. Isotopic Records across two phosphorite giant episodes compared: the Precambrian-cambrian and the Late CretaceousRecent. In: GLENN, C. R.; PRÉVÔT-LUCAS, L.; LUCAS, J. (Ed.). Marine Authigenesis: From Global to Microbial. Tulsa, Oklahoma: SEPM Special Publication, 2000, p.103-115.

SLANSKY, M. Geology of Sedimentary Phosphates. London: North Oxford, 1986. 210p.

SOUDRY, D.; CHAMPETIER, Y. Microbial processes in the Negev phosphorites (southern Israel). Sedimentology, v.30, n.3, p.411-423, 1983.

SOUZA, A. E. D. Balanço Mineral Brasileiro 2001 - Fosfato. DNPM, 2001.Disponível em www.dnpm.gov.br/assets/galeriadocumento/balancomineral2001/fosfato.pdf.

SWETT, K.; KNOLL, A. H. Stromatolitic bioherms and microphytolites from the Late Proterozoic Draken Conglomerate Formation, Spitsbergen Precambrian Research, v.28, n.3-4, p.327-347, 1985.

TOHVER, E.; D'AGRELLA-FILHO, M. S.; TRINDADE, R. I. F. Paleomagnetic record of Africa and South America for the 1200-500 Ma interval, and evaluation of Rodinia and Gondwana assemblies. Precambrian Research, v.147, n.3-4, p.193-222, 2006.

TROMPETTE, R.; ALVARENGA, C. J. S.; WALDE, D. Geological evolution of the Neoproterozoic Corumbágraben system (Brazil). Depositional context of the stratified $\mathrm{Fe}$ and $\mathrm{Mn}$ ores of the Jacadigo Group. Journal of South American Earth Sciences, v.11, n.6, p.587-597doi: DOI: 10.1016/S0895-9811(98)00036-4, 1998.

TUCKER, M. E. Sedimentary Petrology. An Introduction to the Origin of Sedimentary Rocks. 3. Oxford: Blackwell, 2001. 262p.

TUCKER, M. E.; WRIGHT, V. P. Carbonate Sedimentology. Oxford: Blackwell Science, Blackwell Publishing, 1990. 482p.

VAN LITH, Y.; VASCONCELOS, C.; WARTHMANN, R.; MARTINS, J. C. F.; MCKENZIE, J. A. Bacterial sulfate reduction and salinity: two controls on dolomite precipitation in Lagoa Vermelha and Brejo do Espinho (Brazil). Hydrobiologia, v.485, n.1, p.35-49, 2002. 
VAN LITH, Y.; WARTHMANN, R.; VASCONCELOS, C.; MCKENZIE, J. A. Sulphatereducing bacteria induce low-temperature Ca-dolomite and high Mg-calcite formation. Geobiology, v.1, n.1, p.71-79, 2003.

VASCONCELOS, C.; LUNDBERG, R.; BAHNIUK, A.; OCH, L.; MCKENZIE, J. Comparative Study of Modern Stromatolites in Coastal Lagoa Salgada and Lagoa Vermelha, Brazil: Analogues for Precambrian Environmental Evolution. 2009. 2009, 1, p.316.

VASCONCELOS, C.; MCKENZIE, J. A. Microbial mediation of modern dolomite precipitation and diagenesis under anoxic conditions (Lagoa Vermelha, Rio de Janeiro, Brazil). Journal of Sedimentary Research, v.67, n.3, p.378-390, 1997.

VASCONCELOS, C.; MCKENZIE, J. A.; BERNASCONI, S.; GRUJIC, D.; TIENS, A. $\mathrm{J}$. Microbial mediation as a possible mechanism for natural dolomite formation at low temperatures. Nature, v.377, n.6546, p.220-222, 1995.

VASCONCELOS, C.; WARTHMANN, R.; MCKENZIE, J. A.; VISSCHER, P. T.; BITTERMANN, A. G.; VAN LITH, Y. Lithifying microbial mats in Lagoa Vermelha, Brazil: Modern Precambrian relics? Sedimentary Geology, v.185, n.3-4, p.175-183, 2006.

WALTER, M. R. Stromatolites. Elsevier Science Ltd, 1976. v.20, 791p.

WALTHER, J. Geschichte der Erde und des Lebens. Leipzig: Veit \& Comp., 1908. $570 p$.

WARREN, J. Dolomite: occurrence, evolution and economically important associations. Earth-Science Reviews, v.52, n.1-3, p.1-81, 2000.

WARTHMANN, R.; VAN LITH, Y.; VASCONCELOS, C.; MCKENZIE, J. A.; KARPOFF, A. M. Bacterially induced dolomite precipitation in anoxic culture experiments. Geology, v.28, p.1091-1094, 2000.

WRIGHT, D. T. An organogenic origin for widespread dolomite in the Cambrian Eilean Dubh Formation, Northwestern Scotland. Journal of Sedimentary Research, v.67, n.1, p.54-64, 1997.

WRIGHT, D. T. Benthic microbial communities and dolomite formation in marine and lacustrine environments - a new dolomite model. . In: GLENN, C. R.; PRÉVÔTLUCAS, L.; LUCAS, J. (Ed.). Marine Authigenesis: From Global to Microbial. Tulsa, Oklahoma: SEPM Special Publication, 2000, p.7-20.

WRIGHT, D. T.; WACEY, D. Precipitation of dolomite using sulphate-reducing bacteria from the Coorong Region, South Australia: significance and implications. Sedimentology, v.52, n.5, p.987-1008, 2005. 
WRIGHT, J.; SCHRADER, H.; HOLSER, W. T. Paleoredox variations in ancient oceans recorded by rare earth elements in fossil apatite. Geochimica et Cosmochimica Acta, v.51, n.3, p.631-644, 1987.

ZAINE, M. F.; FAIRCHILD, T. R. Novas considerações sobre os fósseis da Formação Tamengo, Grupo Corumbá, SW Brasil. In: Sociedade Brasileira de Paleontologia, Congresso Brasileiro de Paleontologia, 1987, Rio de Janeiro. Resumo das Comunicações, 1987, 10, p.54. 
ANEXO A - Difratogrâmas de raio-X 


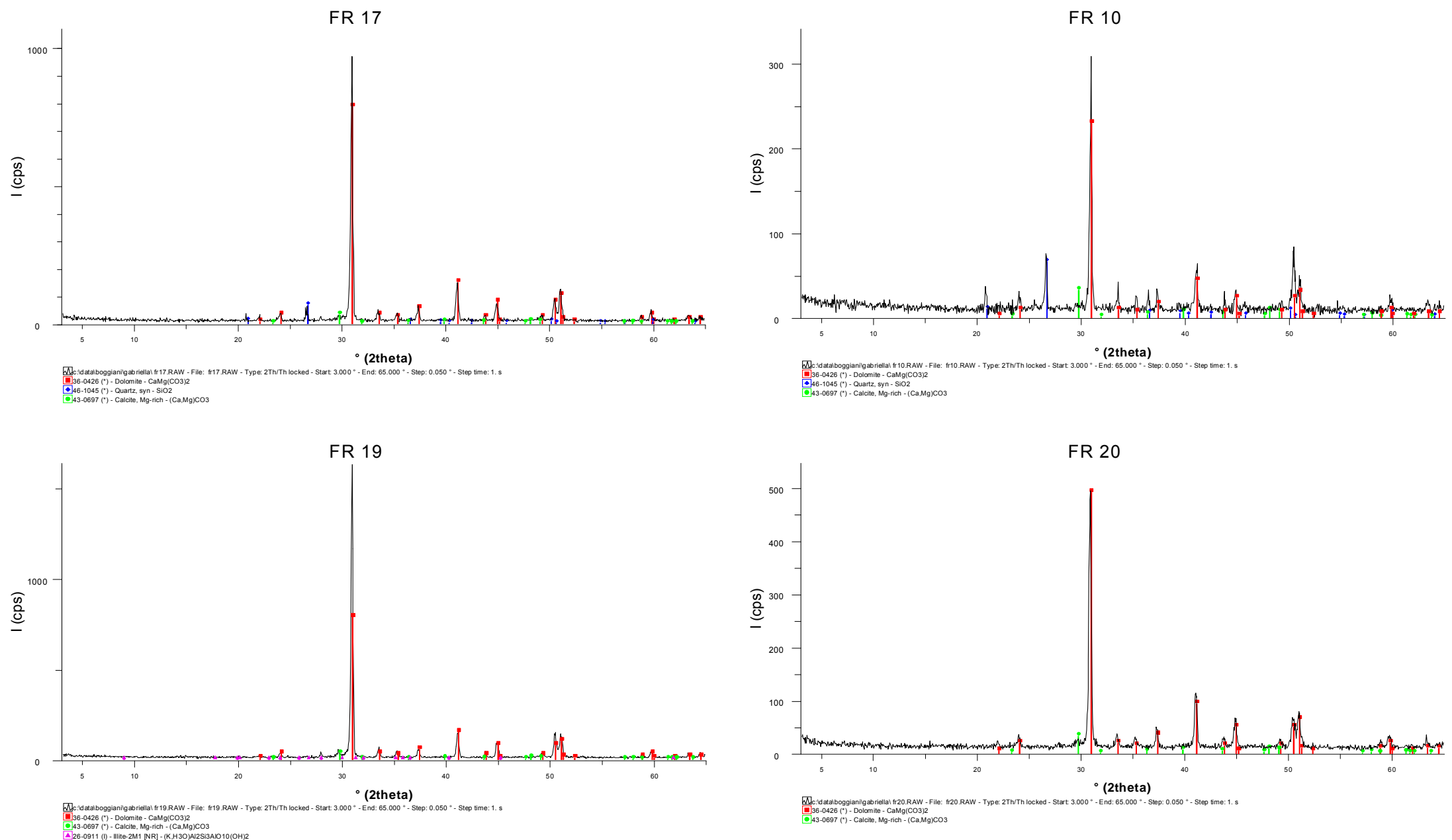

Anexo A - Figura 1: Gráfico de difração de raio-x para dolomitos da Formação Bocaina. A dolomita está indicada nos picos principais, em vermelho Subordinadamente, observa-se calcita (picos em verde) e sílica (picos em azul). 

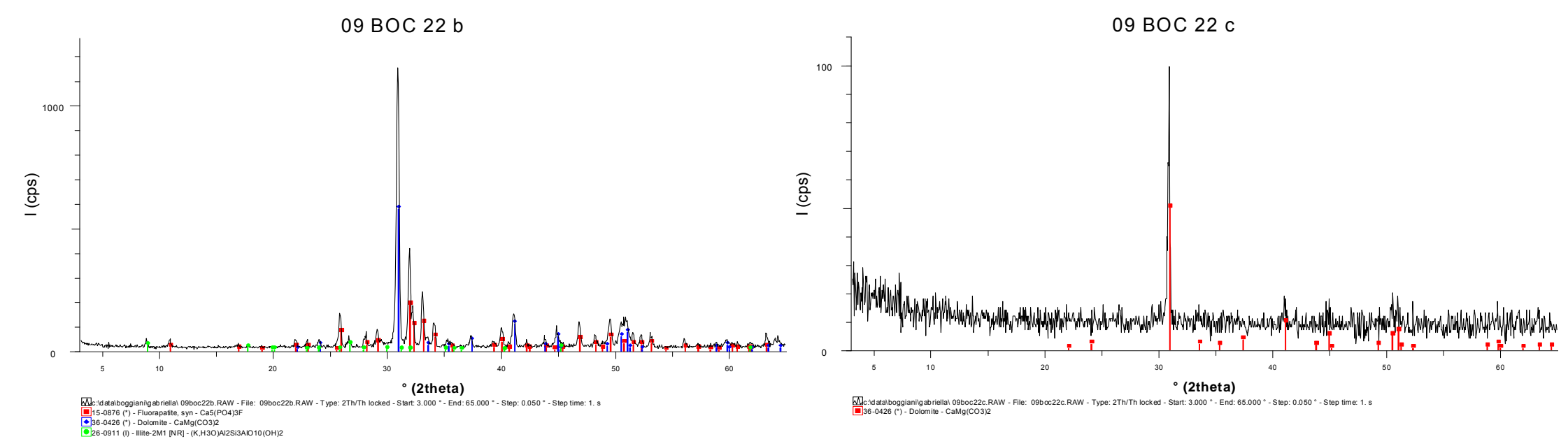

Anexo A - Figura 2: Gráfico de difração de raio-x para sub-fácies de rudstone pisolítico com fosfato (superior esquerda) e rudstone pisolítico não-fosfatizado (superior direita). Para a primeira, a dolomita está indicada nos picos principais, em azul, a apatita em vermelho, e subordinadamente, mica, em verde. Já para a fácies de rudstone pisolítico não-fosfatizado, a dolomita representa a única mineralogia registrada pelo método. 

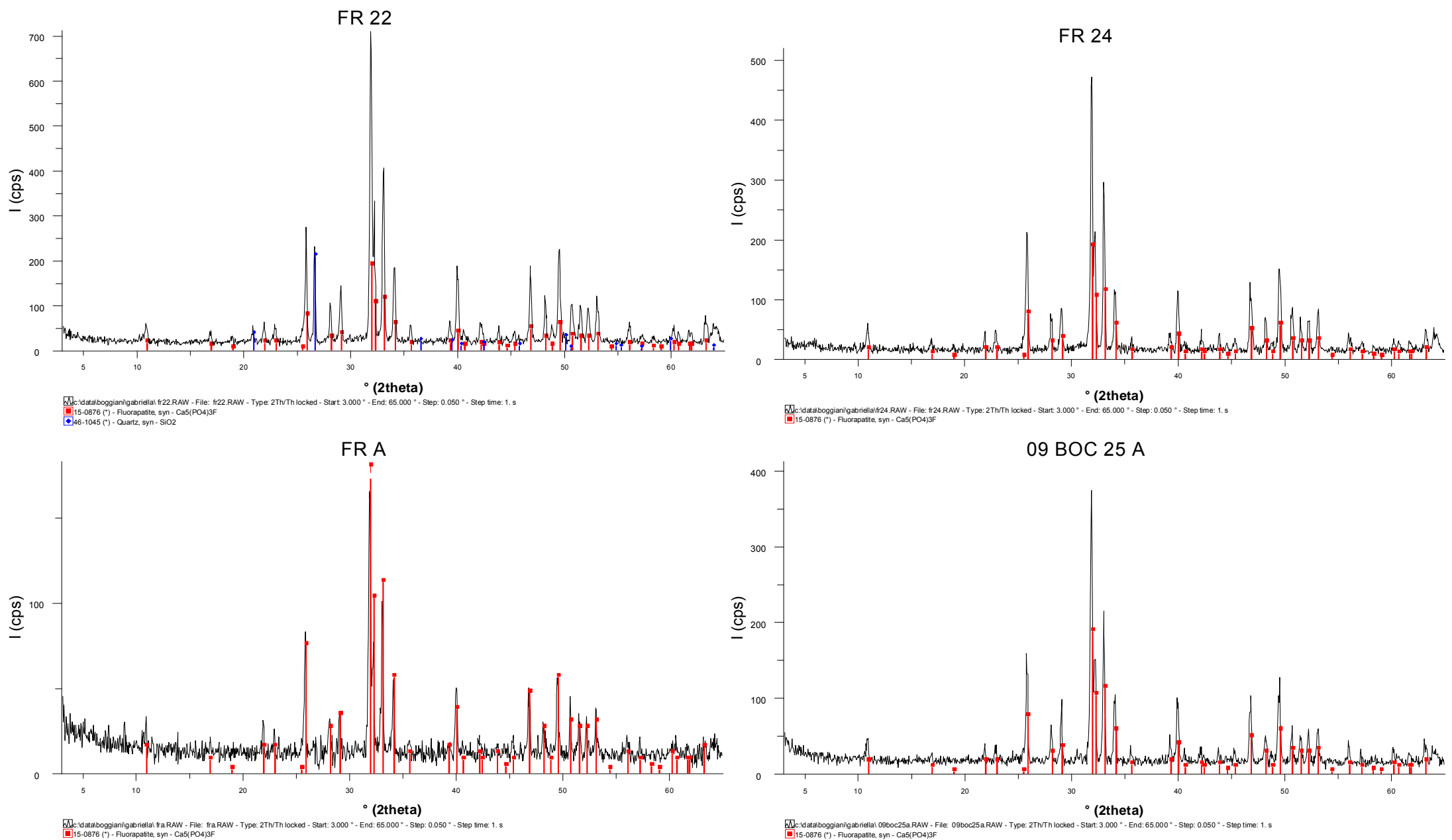

Anexo A - Figura 3: Para as amostras de fosforito a apatita representa mineralogia principal, registrada no pico em vermelho. Subordinadamente, observa-se a presença de quartzo, representado pelo pico em azul na amostra FR-22. 

ANEXO B - Mapa de localização de afloramentos 
FONTANETA, G. T. (2012)

"DOLOMITIZAÇÃO E FOSFOGÊNESE NA FORMAÇÃO BOCAINA

GRUPO CORUMBÁ (EDIACARANO)"

\section{ANEXO B}

\section{Mapa de Localização dos Afloramentos}
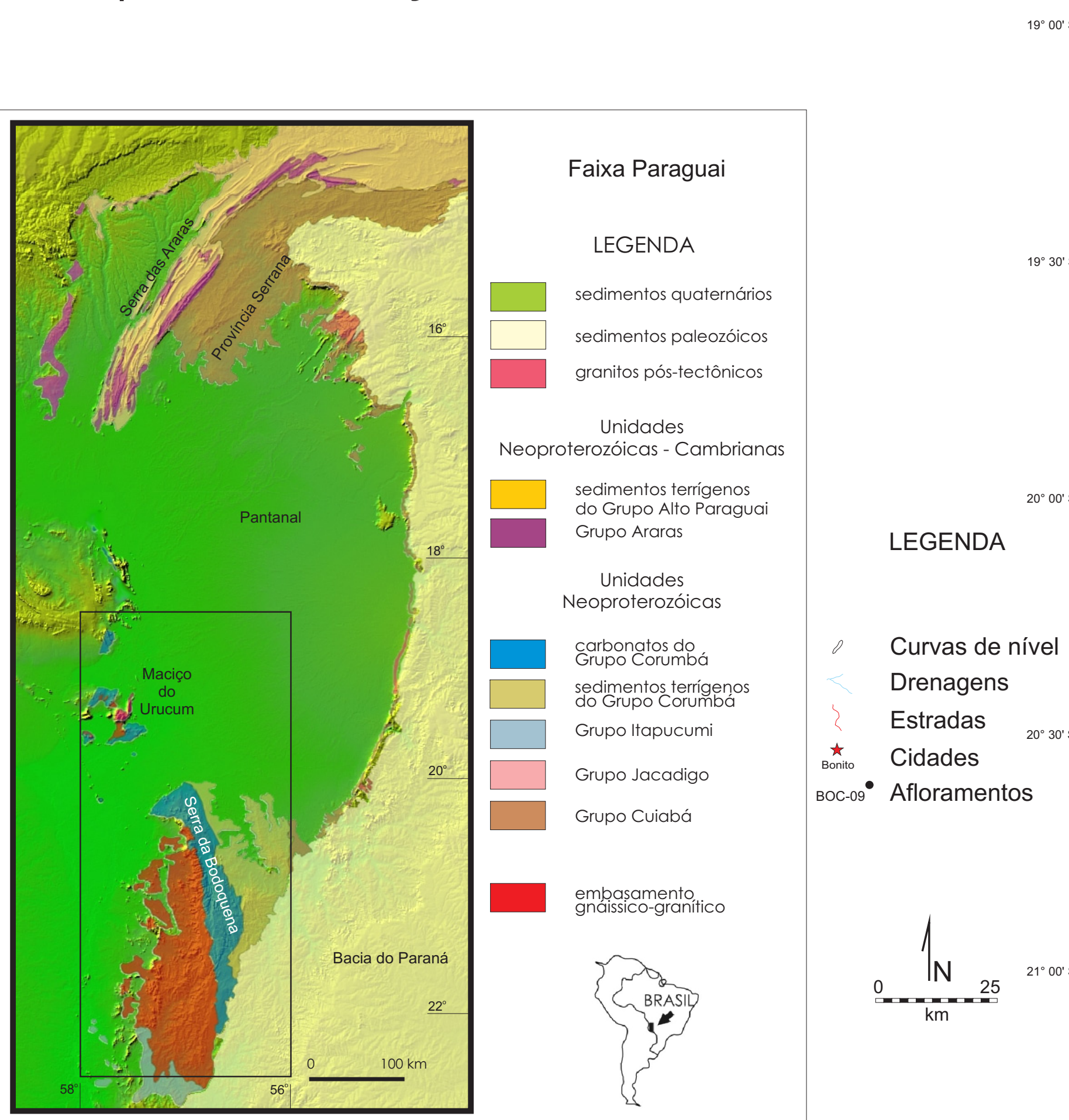

Base de dados: ALVARENGA, C. J. S.; TROMPETTE, R. Evolução Tectônica Brasiliana da Faixa Paraguai: A Estruturação da Região de Cuiabá. Revista Brasileira de Geociências, v.23, n.1, p.18-30, 1993.

. Aces. Shut Acessado em: 12/04/2011, 2006.

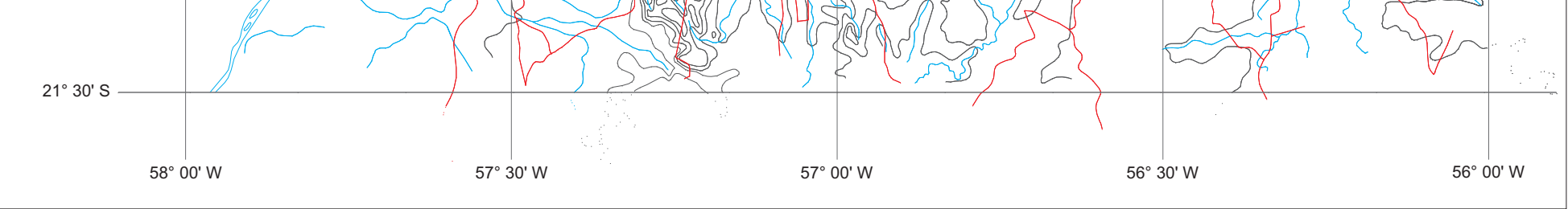


ANEXO C - Tabela de Afloramentos 

Anexo C - Tabela 1 - Localização dos afloramentos, descrição litológica resumida de campo, atitude das camadas, e quais etapas analíticas as amostras foram submetidas [lâmina petrográfica, MEV (microscópio eletrônico de varredura), DRX (difração de raios-X), análises químicas de rocha total, isótopos de $\mathrm{C}$ e O].

\begin{tabular}{|c|c|c|c|c|c|c|c|c|}
\hline Ponto & $\begin{array}{c}\text { Coordenada UTM } \\
(21 \mathrm{~K})\end{array}$ & Descrição litológica de campo & Atitude & $\begin{array}{c}\text { Lâmina } \\
\text { petrográfica }\end{array}$ & MEV & DRX & $\begin{array}{l}\text { Análise } \\
\text { química }\end{array}$ & \begin{tabular}{|c|} 
Isótopos \\
C e O \\
\end{tabular} \\
\hline 08-BOC-01 & $(0548111 ; 7680234)$ & conglomerado de matriz dolomítica e clasto de fosforito & & não tem amostra & & & & \\
\hline 08-BOC-02 & $(0548767 ; 7681171)$ & dolomito cataclástico; zona de falha & & não tem amostra & & & & \\
\hline 08-BOC-03 & $(0546051 ; 7684019)$ & mudstone estratificado; possivel capa carbonática & & 1 & & & & \\
\hline 08-BOC-04 & $(0545935 ; 7684297)$ & diamictito da Fm. Puga & N20/45SE & não tem amostra & & & & \\
\hline 08-BOC-05 & $(0542369 ; 7687413)$ & meta-arenito grosso, ferruginoso, intercalado com pelitos & & não tem amostra & & & & \\
\hline 08-BOC-06 & $(0542396 ; 7688936)$ & $\begin{array}{l}\text { contato entre calcário preto, grosso, oolítico (Fm. Tamengo) } \\
\text { com folhelho ocre, pastilhado }\end{array}$ & N350/50NE & não tem amostra & & & & \\
\hline 08-BOC-07 & $(0542792 ; 7695932)$ & dolomito cataclástico; zona de falha & & não tem amostra & & & & \\
\hline 08-BOC-08 & $(0541111 ; 7693578)$ & $\begin{array}{l}\text { grainstone oolitico com estratificação cruzada, finamente } \\
\text { crenulada (bloco) }\end{array}$ & & 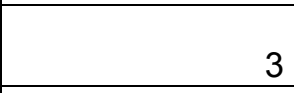 & & & & \\
\hline 08-BOC-09 & $(0548222 ; 7683866)$ & brecha tectônica; zona de falha & N38/50SE & não tem amostra & & & & \\
\hline 08-BOC-10 & $(0547435 ; 7682581)$ & brecha tectônica; zona de falha & N10/38SE & não tem amostra & & & & \\
\hline 08-BOC-11 & $(0534262 ; 7706748)$ & antiga lavra de mármore. Dolomito silicificado, branco & & 2 & & & & \\
\hline 08-BOC-12 & $(0434622 ; 7888602)$ & dolomito oolítico (posto da Receita Federal) & & 1 & & & & \\
\hline 08-BOC-13 & $(0434930 ; 7895671)$ & dolomito cinza maciço com porções silicificadas & & 1 & & & & \\
\hline 09-BOC-14 & $(0542357 ; 7695865)$ & fosforito estromatolítico & & não tem amostra & & & & \\
\hline 09-BOC-15 & $(0542150 ; 7696278)$ & $\begin{array}{l}\text { bloco: dolomito grosso com estrat. cruzada, parcialm. } \\
\text { silicificado }\end{array}$ & & 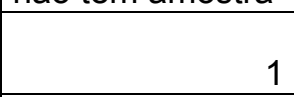 & & & & \\
\hline 09-BOC-16 & $(0542217 ; 7696230)$ & bloco: dolomito com estromatólito colunar & & 2 & & & & \\
\hline 09-BOC-17 & $(0542254 ; 7696217)$ & dolomito com estromatólito colunar ligado lateralmente & & 1 & & & & \\
\hline 09-BOC-18 & $(0542269 ; 7696189)$ & $\begin{array}{l}\text { grainstone grosso plano-paralelo/dolom. com estromatolito } \\
\text { laminado }\end{array}$ & & 3 & & & & \\
\hline 09-BOC-19 & $(0542205 ; 7696212)$ & dolomito com convoluções e níveis de mudstone rosa & & 1 & & & & \\
\hline 09-BOC-20 & $(0542345 ; 7696848)$ & grainstone grosso com intraclastros & & & & & & \\
\hline $09-B O C-21$ & $(0541526 ; 7700291)$ & $\begin{array}{l}\text { blocos de fosforito estratificado/ dolomito pisolítico/ } \\
\text { conglomerado polimítico }\end{array}$ & & 3 & & 1 & & \\
\hline
\end{tabular}




\begin{tabular}{|c|c|c|c|c|c|c|c|c|}
\hline Ponto & $\begin{array}{c}\text { Coordenada UTM } \\
(21 \mathrm{~K})\end{array}$ & Descrição litológica de campo & Atitude & $\begin{array}{c}\text { Lâmina } \\
\text { petrográfica }\end{array}$ & MEV & DRX & $\begin{array}{l}\text { Análise } \\
\text { química }\end{array}$ & \begin{tabular}{|c|} 
Isótopos \\
C e O \\
\end{tabular} \\
\hline 09-BOC-22 & $(0542317 ; 7696287)$ & brecha intraformacional/ dolomito oolítico e fosfatizado & & 8 & 3 & 2 & & \\
\hline 09-BOC-23 & & fosforito fenestral em ravina & & 1 & & & & \\
\hline 09-BOC-24 & $(0542415 ; 7696249)$ & dolomito com estratificação cruzada de baixo ângulo & & & & & & \\
\hline 09-BOC-25 & $(0542394 ; 7695972)$ & fosforito clástico & & 1 & & 1 & & \\
\hline 09-BOC-26' & Rio Paraguai X BR 262 & dolomito estromatolítico róseo com porções fosfatizadas & & 2 & & 1 & & \\
\hline 09-BOC-26 & $(0548028 ; 7680271)$ & conglomerado polimítico com clastos de fosforito & & não tem amostra & & & & \\
\hline 09-BOC-27 & $(0547977 ; 7680200)$ & dolomito maciço fino (mudstone) & & 1 & & & & \\
\hline 09-BOC-28 & $(0547953 ; 7680159)$ & mudstone maciço com dissolução parcial & & & & & & \\
\hline 09-BOC-29 & $(0547922 ; 7680133)$ & $\begin{array}{l}\text { mudstone estratificado com porções silicificadas e veios de } \\
\text { sílica }\end{array}$ & N85/32 & não tem amostra & & & & \\
\hline 09-BOC-30 & $(0547831 ; 7680129)$ & mudstone estratificado, muito silicficado & N65/45 & 1 & & & & \\
\hline 09-BOC-31 & $(0547714 ; 7680149)$ & $\begin{array}{l}\text { mudstone estratificado com boxwork de sílica/ possíveis } \\
\text { estrutras estromatolíticas e ooides }\end{array}$ & & 1 & & & & \\
\hline 09-BOC-32 & $(0548231 ; 7680215)$ & brecha tectônica; zona de falha & & não tem amostra & & & & \\
\hline 09-BOC-33 & $(0548457 ; 7680123)$ & brecha tectônica; zona de falha & & não tem amostra & & & & \\
\hline 09-BOC-34 & $(0542631 ; 7661594)$ & dolomito róseo muito fino, possível capa carbonática & $\mathrm{N} 112 / 22$ & 1 & & & & \\
\hline 09-BOC-35 & $(0539380 ; 7700626)$ & $\begin{array}{l}\text { bloco: dolomito cinza, médio a grosso, recristalizado com } \\
\text { porções de mudstone rosa claro }\end{array}$ & & 1 & & & & \\
\hline 09-BOC-36 & $(0541540 ; 7707395)$ & diamictito Fm. Puga de matriz ferruginosa & & & & & & \\
\hline 09-BOC-37 & $(0542408 ; 7696180)$ & $\begin{array}{l}\text { filito pastilhado ocre-amarronzado (próximo ao açude, na } \\
\text { ravina) }\end{array}$ & & & & & & \\
\hline 09-BOC-38 & $(0543366 ; 7686541)$ & conglomerado polimítico com clastos de fosforito & & & & & & \\
\hline 09-BOC-39 & $(0517001 ; 7760171)$ & mudstone marmorizado e silicificado & & & & & & \\
\hline 09-BOC-40 & $(0522126 ; 7762542)$ & bloco: dolomito rosa metamorfizado e silicificado & & 1 & & & & \\
\hline 09-BOC-41 & $(0522382 ; 7762329)$ & $\begin{array}{l}\text { brecha intraformacional c/ clastos de dolomito fino e matriz } \\
\text { compostas de grãos de quartzo arredado }\end{array}$ & & & & & & \\
\hline 09-BOC-42 & $(0522875 ; 7761875)$ & dolomito cinza escuro com parcial silicificação & & & & & & \\
\hline 09-BOC-43 & $(0523345 ; 7761695)$ & dolomito estratificado & & & & & & \\
\hline 09-BOC-44 & $(0515275 ; 7774737)$ & dolomito fino branco e cinza, com proções silicificadas & & 1 & & & & \\
\hline
\end{tabular}




\begin{tabular}{|c|c|c|c|c|c|c|c|c|}
\hline Ponto & $\begin{array}{c}\text { Coordenada UTM } \\
(21 \mathrm{~K})\end{array}$ & Descrição litológica de campo & Atitude & $\begin{array}{c}\text { Lâmina } \\
\text { petrográfica }\end{array}$ & MEV & DRX & $\begin{array}{l}\text { Análise } \\
\text { química }\end{array}$ & \begin{tabular}{|c|} 
Isótopos \\
$\mathrm{C} \mathrm{e} \mathrm{O}$
\end{tabular} \\
\hline 09-BOC-45 & $(0509667 ; 7772714)$ & $\begin{array}{l}\text { dolomito muito fino, marmorizado e silicificado, com } \\
\text { estrtificação plano paralela }\end{array}$ & & & & & & \\
\hline 09-BOC-46 & $(0500095 ; 7771811)$ & $\begin{array}{l}\text { dolomito estratificado, branco acinzentado marmorizado e } \\
\text { silicificado }\end{array}$ & & 1 & & & & \\
\hline 09-BOC-47 & $(0492601 ; 7779630)$ & dolomito bandado (dolomito/sílex), foliação milonítica & & 1 & & & & \\
\hline 09-BOC-48 & $(0492618 ; 7779860)$ & diamictito de matriz escura, parte maciço e parte foliado & & & & & & \\
\hline 09-BOC-49 & $(0490377 ; 7779935)$ & dolomito cinza claro com estruturas "tepees" & & 1 & & & & \\
\hline 09-BOC-50 & $(0430772 ; 7881441)$ & $\begin{array}{l}\text { brecha intraformacional c/ clastos de dolomito fino e matriz } \\
\text { compostas de grãos de qtz arred. }\end{array}$ & & 2 & & & & \\
\hline 09-BOC-51 & $(0430711 ; 7883556)$ & dolomito cinza claro com estruturas "tepees" e microbrechas & & 2 & & & & \\
\hline 09-BOC-52 & $(0430942 ; 7883866)$ & $\begin{array}{l}\text { brecha intraformacional c/ clastos de dolomito fino e matriz } \\
\text { compostas de grãos de qtz arred. }\end{array}$ & & & & & & \\
\hline $09-B O C-53$ & $(0430140 ; 7886021)$ & $\begin{array}{l}\text { brecha intraformacional c/ clastos dolomíticos e possíveis } \\
\text { estruturas "tepees" }\end{array}$ & & & & & & \\
\hline 09-BOC-54 & $(0429076 ; 7895509)$ & $\begin{array}{l}\text { grainstone cinza, recristal. (ooides)/ z. brechada e falhada } \\
\text { percolado por material rosa e branco }\end{array}$ & & 3 & & 3 & & \\
\hline 09-BOC-55 & $(0439395 ; 7895482)$ & dolomito oolítico/"tepees"/ folhelho/ calcrete & & 6 & & & 1 & \\
\hline FR-01 & $(0542023 ; 7695893)$ & grainstone oolítico & & 1 & & & 1 & 1 \\
\hline FR-02 & & grainstone oolítico & & 1 & & & & 1 \\
\hline FR-03 & & grainstone oolítico & & 1 & & & 1 & 1 \\
\hline FR-04 & & dolomito estromatolítico & & 2 & & & & 1 \\
\hline FR-05 & & dolomito estromatolítico & & 1 & & & 1 & 1 \\
\hline FR-06 & & dolomito estromatolítico / mudstone róseo fino & & 2 & 1 & & & 3 \\
\hline FR-07 & & dolomito estromatolítico & & 1 & & & & 1 \\
\hline FR-08 & & dolomito estromatolítico & & 1 & & & 1 & 1 \\
\hline FR-09 & & dolomito estromatolítico & & & & & 2 & 1 \\
\hline FR-10 & & dolomito estromatolítico & & 1 & 1 & 1 & 1 & 1 \\
\hline FR-11 & & grainstone oolítico silicificado & & 1 & & & & 1 \\
\hline FR-12 & & dolomito estromatolítico/ grainstone oolítico & & 1 & & & & 1 \\
\hline
\end{tabular}




\begin{tabular}{|c|c|c|c|c|c|c|c|c|}
\hline Ponto & $\begin{array}{c}\text { Coordenada UTM } \\
(21 \mathrm{~K})\end{array}$ & Descrição litológica de campo & Atitude & $\begin{array}{c}\text { Lâmina } \\
\text { petrográfica }\end{array}$ & MEV & DRX & $\begin{array}{l}\text { Análise } \\
\text { química }\end{array}$ & $\begin{array}{c}\text { Isótopos } \\
\text { C e O }\end{array}$ \\
\hline FR-13 & & grainstone oolítico & & 1 & & & 1 & 1 \\
\hline FR-14 & & brecha intraformacional & & & & & 1 & 1 \\
\hline FR-15 & & brecha intraformacional & & & & & 1 & 1 \\
\hline FR-16 & & grainstone oolítico & & & & & 1 & 1 \\
\hline FR-17 & & mudstone maciço & & & & 1 & 1 & 1 \\
\hline FR-18 & & grainstone oolítico & & 1 & & & & 1 \\
\hline FR-19 & & grainstone oolítico & & 1 & 1 & 1 & 1 & 1 \\
\hline FR-20 & & brecha intraformacional & & 1 & & 1 & 1 & 1 \\
\hline FR-21 & & fosforito estromatolítico & & 1 & & 1 & & \\
\hline FR-22 & & fosforito estromatolítico & & 1 & & 1 & & \\
\hline FR-23 & & fosforito estromatolítico & & 1 & & 1 & & \\
\hline FR-24 & & fosforito estromatolítico & & 1 & 1 & 1 & & \\
\hline FR-25 & $(0542438 ; 7695915)$ & conglomerado polimítico com clastos de fosforito & & 1 & 1 & 1 & 1 & \\
\hline FR-26 & Sem coordenada & dolomito oncolítico com níveis fosfáticos? & & 3 & & & & \\
\hline FR-A & Sem coordenada & fosforito & & 1 & 2 & 1 & & \\
\hline FR-B & Sem coordenada & fosforito & & 1 & 1 & & & \\
\hline FR-C & Sem coordenada & fosforito & & 1 & 1 & & & \\
\hline FR-D & Sem coordenada & fosforito & & 2 & 1 & & & \\
\hline FR-E & Sem coordenada & fosforito & & 2 & & & & \\
\hline FR-F & Sem coordenada & fosforito & & 1 & & & & \\
\hline FR-G & Sem coordenada & fosforito & & 1 & & & & \\
\hline FR-H & Sem coordenada & fosforito & & 1 & & & & \\
\hline FR-I & Sem coordenada & fosforito & & 1 & & & & \\
\hline LG-1 & Sem coordenada & conglomerado polimítico com clastos de fosfato & & 1 & & 1 & & \\
\hline LG-2 & Sem coordenada & conglomerado polimítico com clastos de fosfato & & & & & & \\
\hline 09-BOC-A & Sem coordenada & estromatólito silicificado & & 1 & & & & \\
\hline
\end{tabular}

